Eliana Martins Pereira

\title{
Estudo do comportamento à expansão de materiais sedimentares da Formação Guabirotuba em ensaios com sucção controlada
}

Tese apresentada à Escola de Engenharia de São Carlos da Universidade de São Paulo, como parte dos requisitos para a obtenção do Título de Doutor em Engenharia Geotécnica.

Orientador: Prof. Dr. Osni José Pejon

São Carlos 
Ao meu pai Aroldo, que agora está ao lado de Deus, mas que em vida foi o maior incentivador desta pesquisa.

A minha querida mãe Édy e ao meu grande amor Miguel, por estarem ao meu lado em todos os momentos da minha vida. 


\section{AGRADECIMENTOS}

Ao Prof. Dr. Osni José Pejon, pela orientação e conhecimentos transmitidos;

Ao Prof. Dr. Chang Hung Kiang e Prof. Dr. Lázaro Valentin Zuquette pelo apoio e incentivo;

Ao Conselho Nacional de Desenvolvimento Científico e Tecnológico - CNPq, pela bolsa concedida;

A todos os docentes, técnicos e funcionários do Departamento de Geotecnia, pelo auxílio e pronto atendimento durante a realização deste estudo;

Ao Eng. Miguel Alfaro Soto, meu marido, colega e amigo, pelo carinho, estímulo, auxílio e apoio em todas as etapas deste estudo;

Aos meus amigos e colegas da Geotecnia, e a todos que de alguma forma contribuíram para a realização desta pesquisa. 


\section{RESUMO}

Este trabalho tem como objetivo principal estudar a influência das variações de sucção no comportamento à expansão dos materiais sedimentares da Formação Guabirotuba, aflorantes na região metropolitana de Curitiba-PR. Foram coletadas amostras indeformadas em cinco pontos característicos dos materiais com maior potencial expansivo na região. As amostras foram, inicialmente, submetidas a ensaios de caracterização para determinação da composição mineralógica da fração fina, da textura, da estrutura, dos índices físicos, dos limites de consistência, da capacidade de troca de cátions e da distribuição de poros. As curvas de retenção de água foram determinadas por ensaios em câmara de pressão, pelo método do papel de filtro e do dessecador de vácuo. Os ensaios de pressão de expansão foram conduzidos em amostras nas quais a sucção foi imposta mediante o uso de soluções salinas. $\mathrm{O}$ umedecimento para provocar a expansão foi realizado tanto por inundação da amostra com água, em ensaios edométricos convencionais, quanto por transferência de vapor, utilizando-se um edômetro, similar ao de Esteban e Sáez (1988), especialmente construído para ser utilizado nessa pesquisa. Os resultados dos ensaios edométricos convencionais mostraram pressões de expansão crescentes com aumento das sucções impostas, atingindo valores de até $4189 \mathrm{kPa}$ para as sucções altas, a amostra mais expansiva. Em contrapartida, os resultados provenientes do edômetro com controle de sucção não acusaram pressão de expansão, nos mesmos materiais e para as mesmas faixas de sucção. Atribui-se este fato às diferenças no processo e na velocidade de umedecimento do material. Constatou-se também neste trabalho que os valores de pressão de expansão, para sucções menores que $1000 \mathrm{kPa}$ são insignificantes nos materiais estudados. Observou-se ainda, a partir de correlações entre atributos mineralógicos e as pressões de expansão, que existe acentuada influência da mineralogia na previsão do potencial expansivo quando a sucção é baixa, porém, quando a sucção cresce, a previsibilidade a partir da mineralogia diminui significativamente.

PALAVRAS-CHAVE: materiais argilosos, expansão, soluções salinas, sucção. 


\section{ABSTRACT}

The main objective of this thesis is to study the influence suction variations of the expansive behavior of sedimentary materials from Guabirotuba Formation, that occours from Curitiba - PR metropolitan area. Undisturbed samples were collected from five characteristic sites with high swelling potential in the region. Different characterization tests were carried out in all the samples in order to determinate clay mineralogy, texture, structure, physical properties, Atterberg limits, cation exchange capacity and pore distribution. The soil-water characteristics curves were obtained by means of pressure plate, the filter paper technique and the desiccator test. The swelling pressure tests were conducted in samples in which the suction was imposed using saline solutions. The wetting of samples to produce swelling was carried out, not only flooding the samples with water in conventional oedometer tests, but also, with vapour transference, using a oedometer similar to Esteban and Sáez (1988), especially made to be used in this research. The results from the conventional oedometer tests showed that the swelling pressure increases with the suctions imposed to the sample, yielding values up to 4189 $\mathrm{kPa}$ for the most expansive sample. On the other hand, the oedometer test results with suction controled did not show swelling pressures, in the same materials and for the same range of suction. This behavior is attributed to differences in the process and in the rate of sample wetting. It was also evidenced that swelling pressure, for lower suctions than $1000 \mathrm{kPa}$ are insignificant. From some correlations between mineralogical attributes and swelling pressure were observed that there is a higher influence of the mineralogy in the swell prediction when the suction is low, however, when the suction increases the swell prediction is less affected by mineralogy.

KEYWORDS: Clayey materials, swelling, saline solutions, suction. 


\section{SUMÁRIO}

RESUMO

ABSTRACT

LISTA DE FIGURAS

LISTA DE TABELAS $\quad \mathrm{x}$

LISTA DE ABREVIATURAS E SIGLAS xiv

LISTA DE SÍMBOLOS $\quad \mathrm{xv}$

1. INTRODUÇÃO 1

1.1 JUSTIFICATIVAS E OBJETIVOS 3

2. REVISÃO BIBLIOGRÁFICA 5

2.1. INSTABILIDADE VOLUMÉTRICA EM MATERIAIS EXPANSIVOS 5

2.1.1. Considerações Gerais 5

2.1.2. Principais Características dos Argilominerais 6

2.1.3. Grupos de Argilominerais 8

2.1.3.1. Grupo das Caulinitas (1:1) 9

2.1.3.2. Grupo das Esmectitas (2:1) 11

2.1.3.3. Grupo das Micas (2:1) 12

a) Ilita 12

2.1.3.4. Grupo da Clorita (2:1:1) 14

2.1.3.5. Grupo da Vermiculita (2:1) 14

2.1.3.6. Grupo dos Interestratificados 14

2.2. MECANISMOS DE EXPANSÃO ASSOCIADOS ÀS PROPRIEDADES $\begin{array}{ll}\text { DOS ARGILOMINERAIS } & 15\end{array}$

2.3. OUTROS FATORES QUE INFLUENCIAM NA EXPANSÃO 19

2.3.1. Influência da Textura da Rocha no Processo Expansivo 22

2.3.2. Compressão de Ar nos Poros 23

2.4. COMPORTAMENTO DOS SOLOS NÃO SATURADOS 24

2.4.1. Considerações Gerais 24

2.4.2. Fases Constituintes do Solo 25

2.4.2.1. Fase sólida $\quad 26$

2.4.2.2. Fase líquida $\quad 26$ 
2.4.3. Potencial de Água no Solo 27

2.4.3.1. Considerações Gerais 27

2.4.3.2. Potencial Gravitacional $(\phi \mathrm{z}) \quad 30$

2.4.3.3. Potencial Pneumático $(\phi \mathrm{p}) \quad 30$

2.4.3.4. Potencial Osmótico (申os) 30

2.4.3.5. Potencial Matricial $(\phi \mathrm{m}) \quad 31$

2.4.4. Sucção Total do Solo (S) 32

2.4.4.1. Sucção Matricial 34

2.4.4.2. Sucção Osmótica 35

2.4.5. Curva de Retenção de Água no Solo 36

2.4.5.1. Histerese 40

2.4.6. Estado de Tensões $\quad 40$

2.4.6.1. Considerações Gerais $\quad 40$

2.4.6.2. Solos saturados e Solos não saturados 41

2.5. MÉTODOS DE IDENTIFICAÇÃO E CLASSIFICAÇÃO DE MATERIAIS EXPANSIVOS 45

2.5.1. Considerações Gerais 45

2.5.2. Técnicas Indiretas 46

2.5.2.1. Difração de Raios - X 47

2.5.2.2. Análise Térmica Diferencial 47

2.5.2.3. Análise Térmica Gravimétrica 48

2.5.2.4. Capacidade de Troca de Íons 48

2.5.2.4.1. Adsorção de Azul de Metileno 49

a) Método da Mancha $\quad 49$

2.5.2.5. Microscopia Eletrônica 50

2.5.2.6. Limites de Atterberg $\quad 50$

2.5.2.7. Atividade 51

2.5.3. Técnicas Diretas 53

2.5.3.1. Expansão Livre $\quad 54$

2.5.3.2. Pressão de Expansão

2.5.3.2.1 Determinação da Pressão de Expansão a partir de Ensaios

Edométricos Convencionais 56 
a) Método da amostra a volume constante 56

b) Ensaio edométrico direto 56

c) Ensaios edométricos múltiplos $\quad 57$

d) Ensaios edométricos duplos $\quad 58$

e) Ensaio edométrico simples $\quad 58$

2.6. MÉTODOS PARA A DETERMINAÇÃO DA SUCÇÃO 59

2.6.1. Considerações Gerais

2.6.2. Técnicas utilizadas em equipamentos para a determinação da sucção $\quad 60$

2.6.2.1. Considerações Gerais $\quad 60$

2.6.2.2. Técnica de Translação de Eixos $\quad 61$

2.6.2.3. Técnica Osmótica 62

2.6.2.4. Técnica de controle de Sucção por Imposição da Umidade Relativa 65

2.6.3. Métodos mais utilizados para a determinação da sucção 66

2.6.3.1. Placa de Sucção $\quad 69$

2.6.3.2. Câmara de Pressão com placa porosa de alta pressão de entrada de ar ou de Richards $\quad 69$

2.6.3.3. Tensiômetro 71

$\begin{array}{ll}\text { 2.6.3.3.1. Tensiômetros de Alta Capacidade } & 71\end{array}$

2.6.3.4. Método do Papel Filtro 71

$\begin{array}{ll}\text { 2.6.3.5. Blocos Porosos } & 76\end{array}$

2.6.3.6. Psicrômetros 76

$\begin{array}{ll}\text { 2.6.3.7. Equilíbrio da Fase Vapor } & 77\end{array}$

2.6.4. Ensaios edométricos sob sucção controlada $\quad 77$

$\begin{array}{ll}\text { 2.6.4.1. Edômetro de membrana } & 77\end{array}$

2.6.4.2. Edômetro com controle de sucção de Escario 78

2.6.4.3. Edômetro com membrana osmótica 79

2.6.4.4. Ensaios edométricos utilizando a técnica de controle de sucção por imposição da umidade relativa $\quad 81$

3. CARACTERÍSTICAS DA ÁREA 83

3.1 LOCALIZAÇÃO DA ÁREA 83

3.2 CARACTERIZAÇÃO GEOLÓGICA 84

3.2.1 Considerações Gerais $\quad 84$

3.2.2. Formação Guabirotuba 
4. MATERIAIS E MÉTODOS 90

$\begin{array}{ll}\text { 4.1 MATERIAIS } & 90\end{array}$

$\begin{array}{ll}\text { 4.1.1 Materiais argilosos analisados } & 90\end{array}$

4.1.2 Amostragem 94

4.2 MÉTODOS DE ENSAIO UTILIZADOS 95

4.2.1 Ensaios de Caracterização 95

4.2.1.1 Análise Granulométrica, Índices Físicos e Limites de Consistência 96

4.2.1.2 Análise Térmica Diferencial (ATD) 96

4.2.1.3 Análise Térmica Gravimétrica (ATG) 96

4.2.1.4 Difração de Raios-X 96

4.2.1.5 Adsorção de Azul de Metileno

$\begin{array}{ll}\text { 4.2.1.6 Porosimetria de Mercúrio } & 99\end{array}$

$\begin{array}{ll}\text { 4.2.1.7 Microscopia Eletrônica de Varredura } & 100\end{array}$

4.2.2 Determinação da Curva de Retenção de Água 100

4.2.2.1 Método da Câmara de Pressão de Richards 101

$\begin{array}{ll}\text { 4.2.2.2 Método do Papel Filtro } & 103\end{array}$

$\begin{array}{ll}\text { 4.2.2.3 Método do dessecador de vácuo } & 105\end{array}$

$\begin{array}{ll}\text { 4.2.2.4 Calibração do Papel Filtro } & 106\end{array}$

4.2.3 Determinação da Condutividade Elétrica do Extrato Aquoso 107

$\begin{array}{ll}\text { 4.2.4 Ensaios de Expansão } & 108\end{array}$

4.2.4.1 Ensaio edométrico convencional utilizando o método da amostra a 108 volume constante

4.2.4.2 Edômetro com controle de sucção de Escario baseado na técnica de 110 translação de eixos

4.2.4.3 Ensaios edométricos utilizando a técnica de controle de sucção por 111 imposição da umidade relativa

$\begin{array}{ll}\text { 4.2.5 Ensaios de Adensamento } & 115\end{array}$

CAPÍTULO 5. APRESENTAÇÃO E ANÁLISE DOS RESULTADOS 116

$\begin{array}{ll}5.1 \text { Ensaios de Caracterização } & 116\end{array}$

5.1.1 Análise Granulométrica, Índices Físicos e Limites de Consistência 116

$\begin{array}{ll}\text { 5.1.2 Análise Térmica Diferencial (ATD) } & 118\end{array}$

$\begin{array}{ll}\text { 5.1.3 Análise Térmica Gravimétrica (ATG) } & 119\end{array}$ 
$\begin{array}{ll}\text { 5.1.5 Adsorção de Azul de Metileno } & 125\end{array}$

$\begin{array}{ll}\text { 5.1.6 Porosimetria por intrusão de Mercúrio } & 129\end{array}$

$\begin{array}{ll}\text { 5.1.7 Microscopia Eletrônica de Varredura (MEV) } & 133\end{array}$

$\begin{array}{ll}\text { 5.1.8 Condutividade Elétrica } & 141\end{array}$

$\begin{array}{ll}5.2 \text { Retenção de Água no Solo } & 141\end{array}$

5.2.1. Resultados dos ensaios de Papel Filtro e Câmara de Pressão 141

5.2.2. Análise dos resultados dos ajustes das curvas de retenção 162

5.2.3. Comparação dos resultados obtidos pelas técnicas da Câmara de Pressão

$\begin{array}{ll}\text { e do Papel Filtro } & 164\end{array}$

5.2.4. Determinação da Sucção Osmótica 167

5.2.4.1. Análise dos resultados de Sucção Total, Matricial e Osmótica 173

5.2.5. Resultados dos ensaios de curva de retenção pelo método do dessecador $\begin{array}{ll}\text { de vácuo } & 176\end{array}$

5.2.6. Resultados da calibração dos papéis filtro através das soluções salinas 177

5.2.7. Técnicas do Dessecador de vácuo e do Papel Filtro 179

$\begin{array}{ll}\text { 5.3. Ensaios de Expansão } & 184\end{array}$

$\begin{array}{ll}\text { 5.3.1. Ensaios edométricos convencionais } & 184\end{array}$

5.3.2. Ensaios edométricos com imposição de umidade relativa 191

5.3.3. Análise dos resultados dos ensaios de caracterização versus ensaios de expansão 193

5.3.4. Análise dos resultados de Pressão de Expansão (kPa) versus Sucção $\begin{array}{ll}\text { Total }(\mathrm{kPa}) & 196\end{array}$

5.3.5. Edômetro com controle de sucção de ESCARIO baseado na técnica de $\begin{array}{ll}\text { Translação de eixos } & 197\end{array}$

5.4. Ensaios de Adensamento 198

6. CONCLUSÃO 203

7. REFERÊNCIAS BIBLIOGRÁFICAS 209 


\section{LISTA DE FIGURAS}

FIGURA 01. Esquema de uma folha tetraédrica de silício e oxigênio (Grim, 7 1962)

FIGURA 02. Esquema de uma folha octaédrica (Grim, 1962) 8

FIGURA 03. Esquema estrutural de base de uma caulinita (Grim, 1962) 10

FIGURA 04. Esquema estrutural de base de uma montmorilonita (Grim, 1962) 11

FIGURA 05. Representação esquemática da estrutura típica de uma montmorilonita (Yong et al., 1992)

FIGURA 06. Esquema estrutural da muscovita. A estrutura da ilita é semelhante (Grim, 1962)

FIGURA 07. Diferentes tipos de água associada com a expansão cristalina (modificado de Velde, 1992)

FIGURA 08. Absorção de água por argilominerais: a) adsorção intercristalina de água num argilomineral do tipo 2:1 não expansivo (ilita); b) absorção intracristalina de água num argilomineral do tipo 2:1 expansivo (montmorilonita) (Gillott, 1987)

FIGURA 09. Modelo proposto para explicar o mecanismo de expansão osmótica entre duas partículas argilosas (Taylor e Smith, 1986)

FIGURA 10. Esquema ilustrativo da definição do Potencial Total de Água no Solo (Vilar, 2000)

FIGURA 11. Esquema ilustrativo da definição de sucção. Sucção: corresponde a ua - uw de sorte a não haver fluxo através da membrana semipermeável. Comumente ua $=p_{\text {atm }}($ Vilar, 2000)

FIGURA 12. Esquema ilustrativo da definição de sucção matricial, osmótica e total (Vilar, 2000)

FIGURA 13. Posições relativas das curvas de retenção para diferentes solos (Vilar, 2000)

FIGURA 14. Caracterização da curva de retenção segundo Fredlund, Xing e Huang (1994)

FIGURA 15. Classificação da expansibilidade de argilominerais e materiais argilosos segundo Williams e Donaldson, 1980 
FIGURA 16. Representação dos dados de VB versus porcentagem da fração argilosa, com os respectivos valores de Expansão Livre (\%) determinados para os 11 materiais argilosos e a separação de porções do material que apresentam potenciais expansivos distintos

FIGURA 17. Esquema do ensaio de Expansão Livre (ISRM, 1989) 55

FIGURA 18. Representação do ensaio edométrico direto 57

FIGURA 19. Ensaio edométrico múltiplo 58

FIGURA 20. Câmara de pressão de Richards (Libardi, 1995) 70

FIGURA 21. Tipos de fluxo do solo para o papel filtro (Marinho, 1995) 75

FIGURA 22. Mapa de localização da área de estudo 83

FIGURA 23. Distribuição da Formação Guabirotuba na Região Metropolitana de Curitiba. Fonte: Mapa Geológico do Estado do Paraná, DNPM/Mineropar/1989 (Felipe, 1998)

FIGURA 24. Perfil típico de alteração da Formação Guabirotuba (Felipe, 1999)

FIGURA 25. Mapa Geológico (Pereira, 1999), no qual estão representados os pontos onde foram obtidas as amostras dos materiais estudados

FIGURA 26. a) Aspecto do material 1 e b) Talude onde foi retirado o material 1 indeformado

FIGURA 27. a) Aspecto do "empastilhamento" apresentado pelo material 2 quando exposto a ciclos de secagem e umedecimento e b) Local de retirada do material 2 indeformado

FIGURA 28. a) Material argiloso analisado e b) Local de retirada do material 393

FIGURA 29. a) Aspecto do material argiloso e b) Local de retirada do material 493

FIGURA 30. a) Aspecto do material 5 e b) Local de retirada do material 5

FIGURA 31. Coleta do material indeformado: ajuste da caixa metálica no material

FIGURA 32. Amostragem indeformada: material pronto para ser parafinado

FIGURA 33. Fluxograma do ensaio de adsorção de azul de metileno pelo método do papel de filtro (Pejon, 1992)

FIGURA 34. Saturação da placa porosa e dos materiais antes de iniciar o ensaio 
FIGURA 38. Amostras sendo submetidas à imposição de sucção no dessecador de vácuo

FIGURA 39. Calibração dos papéis filtro Whatman $n^{\circ} 42$

FIGURA 40. Equipamento utilizado para o ensaio de Pressão de Expansão a volume constante

FIGURA 41. Imposição da Umidade Relativa através do método do dessecador de vácuo

FIGURA 42. Peças confeccionadas para o edômetro com imposição de umidade relativa

FIGURA 43. Equipamento utilizado para a realização do ensaio edométrico com imposição de umidade relativa

FIGURA 44. Dessecadores onde foram impostas as sucções nos materiais

FIGURA 45. Curvas de distribuição granulométrica dos cinco materiais analisados

FIGURA 46. Termogramas obtidos para os materiais argilosos

FIGURA 47. Representação da curva termogravimétrica para o material 1

FIGURA 48. Representação da curva termogravimétrica para o material 2

FIGURA 49. Representação da curva termogravimétrica para o material 3

FIGURA 50. Representação da curva termogravimétrica para o material 4

FIGURA 51. Representação da curva termogravimétrica para o material 5

FIGURA 52. Representação dos difratogramas obtidos para o material 1: a) normal; b) etilenoglicol e c) aquecido a $550^{\circ} \mathrm{C}$

FIGURA 53. Representação dos difratogramas obtidos para o material 2: a) normal; b) etilenoglicol e c) aquecido a $550^{\circ} \mathrm{C}$

FIGURA 54. Representação dos difratogramas obtidos para o material 3: a) normal; b) etilenoglicol e c) aquecido a $550^{\circ} \mathrm{C}$

FIGURA 55. Representação dos difratogramas obtidos para o material 4: a) normal; b) etilenoglicol e c) aquecido a $550^{\circ} \mathrm{C}$

FIGURA 56. Representação dos difratogramas obtidos para o material 5: a) normal; b) etilenoglicol e c) aquecido a $550^{\circ} \mathrm{C}$

FIGURA 57. Distribuição do tamanho dos poros para os cinco materiais estudados 
FIGURA 58. Distribuição do tamanho dos poros para os cinco materiais em termos percentuais

FIGURA 59. Diâmetro dos poros em função do Logaritmo do Volume Diferencial de Mercúrio introduzido na amostra do material 1

FIGURA 60. Diâmetro dos poros em função do Logaritmo do Volume

Diferencial de Mercúrio introduzido nas amostra dos materiais 2, 3, 4 e 5

FIGURA 61. Curvas de Volume de Poros Acumulados em função da Pressão Absoluta Aplicada

FIGURA 62. Composição mineralógica do material 1. Presença de caulinita, ilita e montmorilonita

FIGURA 63. Imagem da amostra do material 1, mostrando a presença de caulinita e haloisita

FIGURA 64. Fendas geradas no material 2, devido ao processo de secagem

FIGURA 65. Aspecto da textura orientada do material 2

FIGURA 66. Vazios de grandes dimensões no material 3

FIGURA 67. Detalhe dos microvazios entre as placas dos argilominerais no material 3

FIGURA 68. Presença de trincas de grandes dimensões no material 4

FIGURA 69. Aspecto geral da textura do material 4

FIGURA 70. a) Presença de feldspato na composição mineralógica do material 5 e b) Composição química do mineral central (feldspato sódico alterado)

FIGURA 71. Aspecto de argilominerais do grupo das esmectitas (montmorilonita) presentes no material 5

FIGURA 72. Detalhe da foto anterior

FIGURA 73. Curva de retenção para o material 1 (Papel Filtro)

FIGURA 74. Curva de retenção para o material 2 (Papel Filtro)

FIGURA 75. Curva de retenção para o material 3 (Papel Filtro)

FIGURA 76. Curva de retenção para o material 4 (Papel Filtro)

FIGURA 77. Curva de retenção para o material 5 (Papel Filtro)

FIGURA 78. Curva de retenção para o material 1 (Papel Filtro)

FIGURA 79. Curva de retenção para o material 2 (Papel Filtro)

FIGURA 80. Curva de retenção para o material 3 (Papel Filtro) 
FIGURA 82. Curva de retenção para o material 5 (Papel Filtro)

FIGURA 83. Curva de retenção para o material 1 (Câmara de Pressão)

FIGURA 84. Curva de retenção para o material 2 (Câmara de Pressão)

FIGURA 85. Curva de retenção para o material 3 (Câmara de Pressão)

FIGURA 86. Curva de retenção para o material 4 (Câmara de Pressão)

FIGURA 87. Curva de retenção para o material 5 (Câmara de Pressão)

FIGURA 88. Representação dos dados de Variação de volume e Sucção matricial para o material 1

FIGURA 89. Representação dos dados de Variação de volume e Sucção matricial para o material 2

FIGURA 90. Representação dos dados de Variação de volume e Sucção matricial para o material 3

FIGURA 91. Representação dos dados de Variação de volume e Sucção matricial para o material 4

FIGURA 92. Representação dos dados de Variação de volume e Sucção matricial para o material 5

FIGURA 93. Curvas de retenção para amostras do material 3

FIGURA 94. Curvas de retenção para amostras do material 5

FIGURA 95. Curvas de retenção obtidas para o material 1 (Papel Filtro)

FIGURA 96. Curvas de retenção obtidas para o material 2 (Papel Filtro)

FIGURA 97. Curvas de retenção obtidas para o material 3 (Papel Filtro)

FIGURA 98. Curvas de retenção obtidas para o material 4 (Papel Filtro)

FIGURA 99. Curvas de retenção obtidas para o material 5 (Papel Filtro)

FIGURA 100. Representação dos dados de umidade gravimétrica normalizada e sucção osmótica $(\mathrm{kPa})$ para os cinco materiais

FIGURA 101. Representação dos dados de condutividade elétrica em função dos valores de sucção osmótica inicial para cada material

FIGURA 102. Representação dos dados de condutividade elétrica em função dos valores de sucção osmótica final para cada material

FIGURA 103. Curvas de Retenção obtidas para os cinco materiais pelo método do Papel Filtro (Sucção Matricial)

FIGURA 104. Curvas de Retenção obtidas para os cinco materiais pelo método do Papel Filtro (Sucção Total) 
FIGURA 105. Representação dos dados de umidade gravimétrica (\%) e sucção osmótica $(\mathrm{kPa})$ para os cinco materiais

FIGURA 106. Representação das Curvas de retenção geradas a partir do método do dessecador de vácuo

FIGURA 107. Representação conjunta dos dados experimentais gerados para a calibração do papel filtro Whatman $n^{\circ} 42$

FIGURA 108. Análise dos dados experimentais (umidade gravimétrica (\%) e sucção total $(\mathrm{kPa}))$ obtidos para o Material 1 (papel filtro)

FIGURA 109. Análise dos dados experimentais (umidade gravimétrica (\%) e sucção total $(\mathrm{kPa}))$ obtidos para o Material 2 (papel filtro)

FIGURA 110. Análise dos dados experimentais (umidade gravimétrica (\%) e sucção total $(\mathrm{kPa})$ ) obtidos para o Material 3 (papel filtro)

FIGURA 111. Análise dos dados experimentais (umidade gravimétrica (\%) e sucção total $(\mathrm{kPa}))$ obtidos para o Material 4 (papel filtro)

FIGURA 112. Análise dos dados experimentais (umidade gravimétrica (\%) e sucção total $(\mathrm{kPa}))$ obtidos para o Material 5 (papel filtro)

FIGURA 113. Dados experimentais obtidos neste estudo e de diversos autores (Marinho, 1995) da calibração do papel filtro Whatman $n^{\circ} 42$, bem como, a curva de ajuste a partir de Chandler et al. (1992)

FIGURA 114. Correção da sucção total em função da temperatura para as soluções salinas saturadas de Cloreto de Sódio, Potássio e Bário

FIGURA 115. Resultados dos ensaios de Pressão de Expansão para o material 1

FIGURA 116. Resultados dos ensaios de Pressão de Expansão para o material 2

FIGURA 117. Resultados dos ensaios de Pressão de Expansão para o material 3

FIGURA 118. Resultados dos ensaios de Pressão de Expansão para o material 4

FIGURA 119. Resultados dos ensaios de Pressão de Expansão para o material 5

FIGURA 120. Resultados do IM e Pressões de Expansão para as diferentes sucções impostas

FIGURA 121. Resultados do ICM e Pressões de Expansão para as diferentes sucções impostas

FIGURA 122. Resultados das Pressões de Expansão obtidas para as sucções impostas por umidade relativa 
FIGURA 124. Resultados do ensaio de adensamento para o material 2

FIGURA 125. Resultados do ensaio de adensamento para o material 3

FIGURA 126. Resultados do ensaio de adensamento para o material 4

FIGURA 127. Resultados do ensaio de adensamento para o material 5

FIGURA 128. Tensão de pré-adensamento versus sucção total (da amostra antes do umedecimento) para os materiais analisados 


\section{LISTA DE TABELAS}

TABELA 01. Sistemática dos Minerais Argilosos (Gomes, 1986)

TABELA 02. Relações empíricas para estimar a curva de retenção de água no solo

TABELA 03. Equações para tensões efetivas em solos não saturados (Fredlund e Morgenstern, 1977)

TABELA 04. Síntese de métodos utilizados para a determinação de medida de sucção nos solos (Vilar, 2000)

TABELA 05. Técnicas mais usadas para calibração do papel filtro (Marinho, 1995)

TABELA 06. Correlações para determinação da sucção com o método do papel filtro (Vilar, 1997)

TABELA 07. Sugestão para o tempo de equilíbrio para a medição da sucção total em função do nível de sucção (Marinho, 1995)

TABELA 08. Características geotécnicas dos materiais

TABELA 09. Dados obtidos nos ensaios de ATG

TABELA 10. Análise semiquantitativa para os difratogramas de Raios $-\mathrm{X}$

TABELA 11. Resultados dos Ensaios de Adsorção de Azul de Metileno para as amostras dos materiais 1,2 e 3

TABELA 12. Resultados dos Ensaios de Adsorção de Azul de Metileno para as amostras dos materiais 4 e 5

TABELA 13. Estimativa da porcentagem de macroporos, mesoporos e microporos nas amostras analisadas para os cinco materiais

TABELA 14. Dados Experimentais de Umidade gravimétrica (\%) e Sucção matricial $(\mathrm{kPa})$ obtidos para os materiais 1,2 e 3, a partir do método do Papel Filtro

TABELA 15. Dados Experimentais de Umidade gravimétrica (\%) e Sucção matricial $(\mathrm{kPa})$ obtidos para os materiais 4 e 5, através do método do Papel Filtro 
TABELA 16. Parâmetros de ajuste da Curva de Retenção através da equação matemática de Farrel \& Larson (1972)

TABELA 17. Parâmetros de ajuste da Curva de Retenção através da equação matemática de Simmons, Nielsen \& Biggar (1979)

TABELA 18. Parâmetros de ajuste da Curva de Retenção através da equação matemática de Libardi et al. (1979)

TABELA 19. Parâmetros de ajuste da Curva de Retenção através da equação matemática de Van Genuchten (1980)

TABELA 20. Parâmetros de ajuste da Curva de Retenção através da equação matemática de Driessen (1986)

TABELA 21. Parâmetros de ajuste da Curva de Retenção através da equação matemática de Fredlund et al. (1994)

TABELA 22. Dados Experimentais de Umidade gravimétrica (\%) versus Sucção total $(\mathrm{kPa})$ obtidos para os materiais 1,2 e 3, através do Método do Papel Filtro

TABELA 23. Dados Experimentais de Umidade gravimétrica (\%) versus Sucção total $(\mathrm{kPa})$ obtidos para os materiais 4 e 5 , a partir do método do Papel 148 Filtro

TABELA 24. Parâmetros de ajuste da Curva de Retenção através da equação matemática de Farrel \& Larson (1972)

TABELA 25. Parâmetros de ajuste da Curva de Retenção através da equação matemática de Simmons, Nielsen \& Biggar (1979)

TABELA 26. Parâmetros de ajuste da Curva de Retenção através da equação matemática de Libardi et al. (1979)

TABELA 27. Parâmetros de ajuste da Curva de Retenção através da equação matemática de Van Genuchten (1980)

TABELA 28. Parâmetros de ajuste da Curva de Retenção através da equação matemática de Driessen (1986)

TABELA 29. Parâmetros de ajuste da Curva de Retenção através da equação matemática de Fredlund et al. (1994)

TABELA 30. Resultados experimentais obtidos no ensaio de câmara de pressão para os materiais 1,2 e 3 
TABELA 31. Resultados experimentais obtidos no ensaio de câmara de pressão para os materiais 4 e 5

TABELA 32. Parâmetros de ajuste da Curva de Retenção através da equação matemática de Farrel \& Larson (1972)

TABELA 33. Parâmetros de ajuste da Curva de Retenção através da equação matemática de Simmons, Nielsen \& Biggar (1979)

TABELA 34. Parâmetros de ajuste da Curva de Retenção através da equação matemática de Libardi et al. (1979)

TABELA 35. Parâmetros de ajuste da Curva de Retenção através da equação matemática de Van Genuchten (1980)

TABELA 36. Parâmetros de ajuste da Curva de Retenção através da equação matemática de Driessen (1986)

TABELA 37. Parâmetros de ajuste da Curva de Retenção através da equação matemática de Fredlund et al. (1994)

TABELA 38. Resultados para amostras do material 1

TABELA 39. Resultados para amostras do material 2

TABELA 40. Resultados para amostras do material 3

TABELA 41. Resultados para amostras do material 4

TABELA 42. Resultados para amostras do material 5

TABELA 43. Resultados dos erros de estimativa obtidos para o método da Câmara de Pressão (sucção matricial)

TABELA 44. Resultados dos erros de estimativa obtidos para o método do Papel Filtro (sucção matricial)

TABELA 45. Intervalos de dados de umidade gravimétrica (\%) e respectivas Sucções Osmóticas $(\mathrm{kPa})$, Sucções Osmóticas médias e Condutividade Elétrica para os cinco materiais

TABELA 46. Resultados de Umidade Gravimétrica (\%) e Sucção Total (kPa), obtidos através do método do dessecador de vácuo

TABELA 47. Parâmetros de ajuste da Curva de Retenção através da equação matemática de Fredlund et al. (1994)

TABELA 48. Dados experimentais obtidos para a calibração do papel filtro Whatman $n^{\circ} 42$

TABELA 49. Índices físicos das amostras ensaiadas 
TABELA 50. Resultados obtidos para o ensaio de Pressão de Expansão no Edômetro convencional para as amostras dos cinco materiais

TABELA 51. Valores de sucção total em função da temperatura, umidade relativa para a solução salina de Cloreto de sódio saturado

TABELA 52. Valores de sucção total em função da temperatura, umidade relativa para a solução salina de Cloreto de potássio saturado

TABELA 53. Valores de sucção total em função da temperatura, umidade relativa para a solução salina de Cloreto de bário saturado

TABELA 54. Resultados obtidos para o ensaio de expansibilidade realizados nos Edômetros com imposição de umidade relativa para as amostras dos materiais 3 e 5

TABELA 55. Resultados obtidos para o ensaio de expansibilidade realizado no dessecador de vácuo para amostras dos materiais 1, 2, 3 e 4

TABELA 56. Parâmetros usados e resultados da relação entre eles 194

TABELA 57. Parâmetros utilizados e resultados da relação entre eles 195 


\section{LISTA DE ABREVIATURAS E SIGLAS}

AASHTO American Association of State Highway and Transportation Officials;

ABNT Associação Brasileira de Normas Técnicas;

Acb quantidade de azul de metileno adsorvido em $100 \mathrm{~g}$ de argila contida no solo;

ASTM American Society for Testing and Materials;

ATD Análise Térmica Diferencial;

ATG Análise Térmica Gravimétrica;

CTC capacidade de troca de cátions em $\mathrm{cmol}^{(+)} / \mathrm{Kg}$;

HRB Highway Research Board;

IP índice de plasticidade;

I.S.R.M. International Society for Rock Mechanics;

LL Limite de Liquidez;

LP Limite de Plasticidade;

MB Método de ensaio;

MEV Microscópio Eletrônico de Varredura;

NBR Norma Brasileira Registrada;

PEG polietileno de glicol;

SE $\quad$ superfície específica da fração total do solo e da fração $\operatorname{argila~}\left(\mathrm{m}^{2} / \mathrm{g}\right)$;

SPT resistência à penetração Standard;

SUCS Sistema Unificado de Classificação de Solos;

SWCC Soil Water Characteristic Curve;

SWRC Soil Water Retention Curve;

USCS Unified Soil Classification System;

USP Universidade de São Paulo;

VB quantidade de azul de metileno adsorvido em $100 \mathrm{~g}$ de solo; 


\section{LISTA DE SÍMBOLOS}

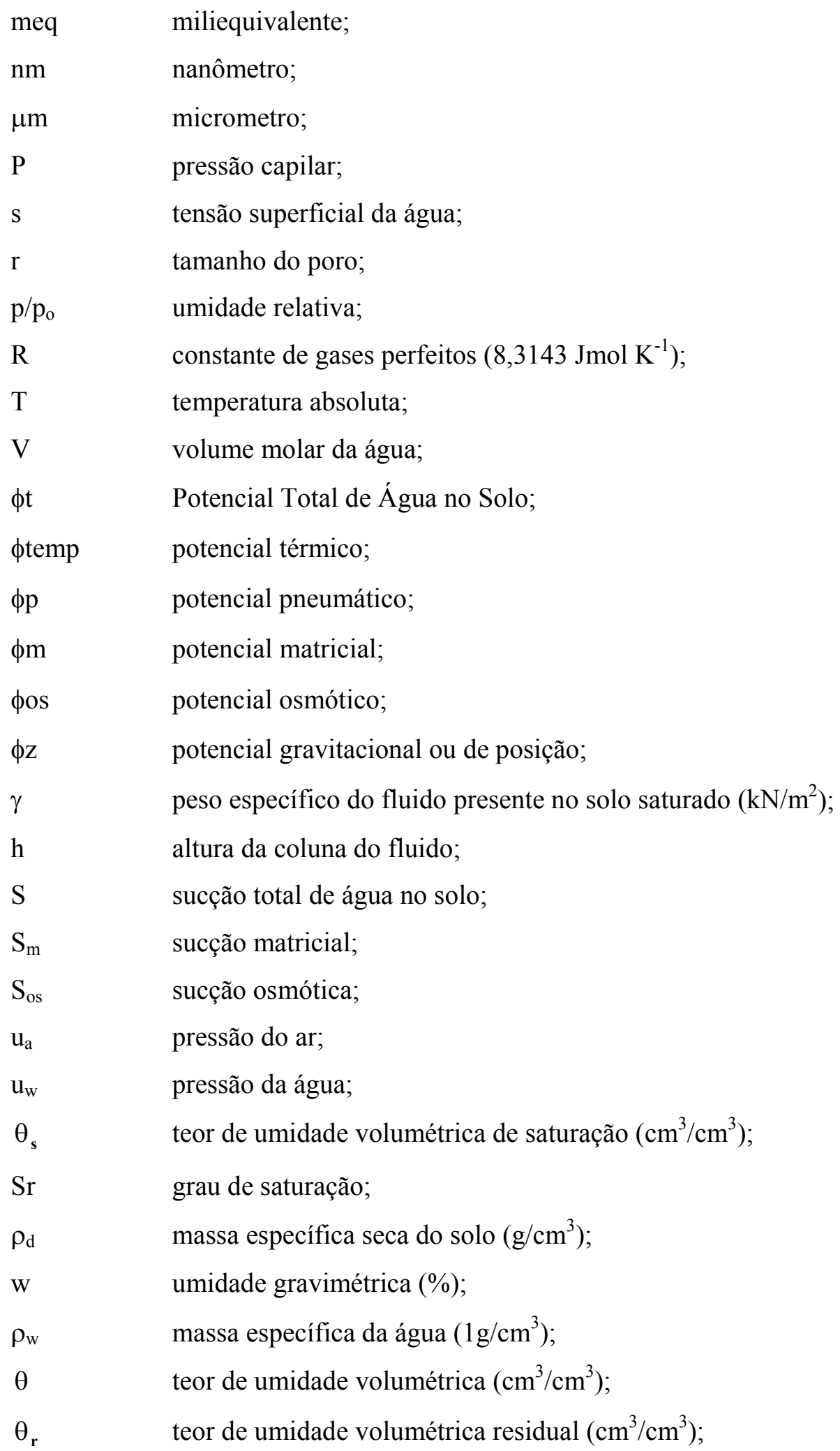




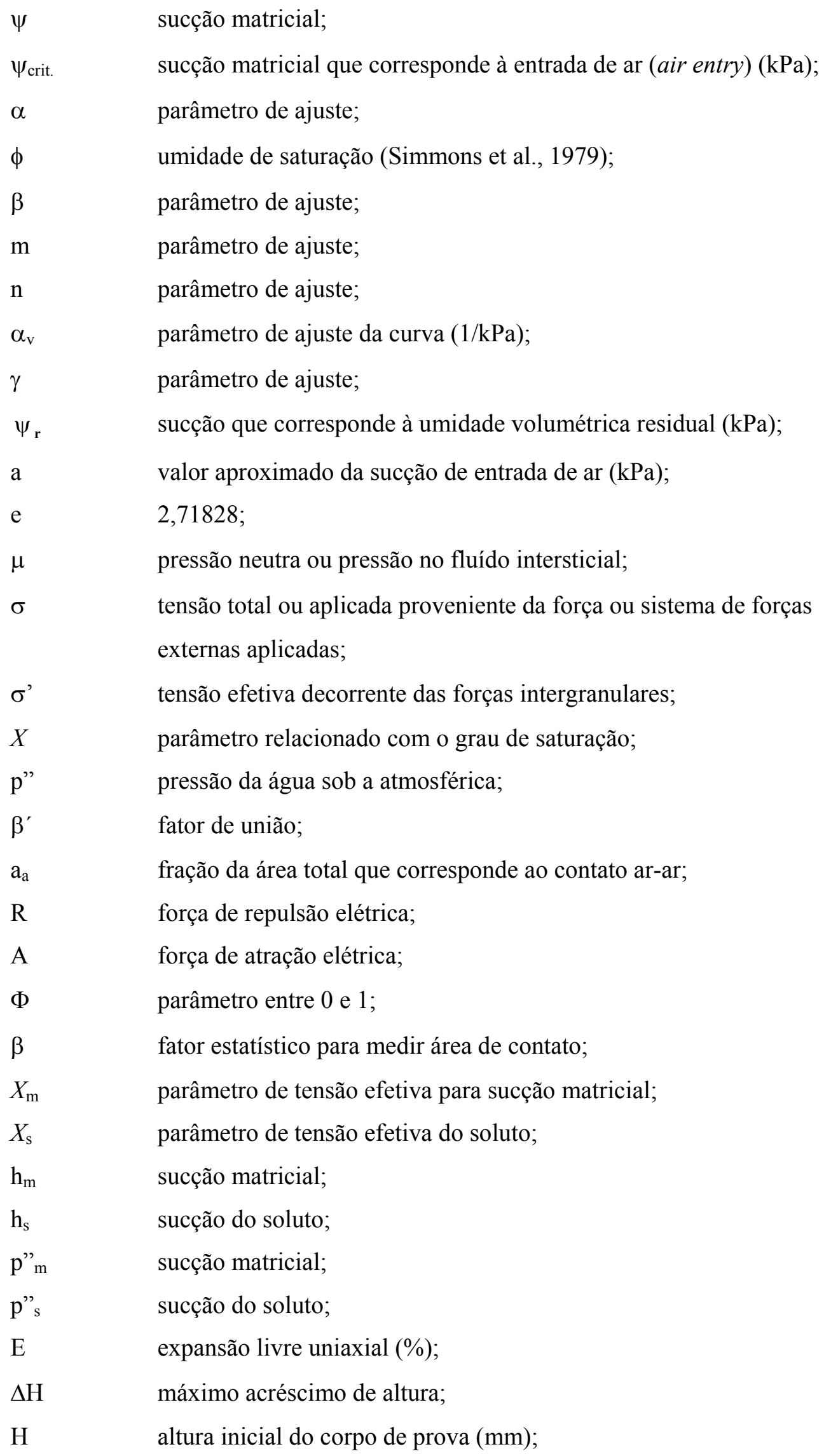




$\begin{array}{ll}\mathrm{M} & \text { massa molar da água }\left(18,016 \mathrm{gmol}^{-1}\right) ; \\ \mathrm{g} & \text { aceleração gravitacional }\left(9,81 \mathrm{~ms}^{-2}\right) ; \\ \mathrm{p} & \text { pressão parcial de vapor; } \\ \mathrm{p}_{\mathrm{o}} & \text { pressão de vapor de saturação } \\ \mathrm{RT} / \mathrm{Mg} & 137.837 \mathrm{kPa} ; \\ \mathrm{pF} & \text { logaritmo da pressão expresso em centímetros de coluna d'água; } \\ \mathrm{V} & \text { volume da solução de azul de metileno adsorvido (ml); } \\ \mathrm{C} & \text { concentração da solução de azul de metileno (em normalidade); } \\ \mathrm{Ms} & \text { massa do solo seco }(\mathrm{g}) ; \\ \rho_{\mathrm{s}} & \text { massa específica dos sólidos }\left(\mathrm{g} / \mathrm{cm}^{3}\right) ; \\ \rho_{\mathrm{d}} & \text { massa específica seca; } \\ \rho & \text { massa específica do solo; } \\ \mathrm{e} & \text { índice de vazios; } \\ n & \text { porosidade; } \\ \mu \mathrm{S} & \text { microsiemens. }\end{array}$




\section{CAPÍTULO 1. INTRODUÇÃO}

A presença de argilas expansivas em rochas e solos causa constante preocupação entre os pesquisadores e profissionais que trabalham com obras geotécnicas, porque o uso indiscriminado deste material, seja compactado ou em seu estado natural, vêm gerando grandes prejuízos a tais obras. Deste fato, resulta o interesse, a validade e a importância dos constantes trabalhos relacionados a este assunto. Estes materiais podem gerar instabilidade em taludes, subleito de pavimentos, fundações de grandes estruturas, desabamento de túneis, devido, principalmente, a sua propriedade de expansibilidade (Frazão e Goulart, 1976).

Esses problemas despertam inúmeras investigações, que são realizadas em várias regiões do mundo onde ocorrem materiais potencialmente expansivos, buscando caracterizar o fenômeno da variação volumétrica. Por variação volumétrica entende-se a expansão ou contração do material potencialmente expansivo devido ao ganho ou perda de água, respectivamente, que criam pressões indesejáveis nas estruturas das obras de engenharia.

Os materiais expansivos constituem também um problema de solos não saturados (Costa Nunes, 1978). Assim, é de grande interesse o estudo das possíveis variáveis que afetam de forma significativa seu comportamento, sendo uma delas a sucção, a qual se admite ser um dos principais fatores condicionantes no comportamento hidráulico (movimento de água nos poros) e mecânico (expansão-contração, deformação, resistência, etc.) desses solos (Chenggang et al., 1988). A esse respeito, têm-se desenvolvido nestes últimos anos, diversas técnicas de ensaio, tanto de campo, como de laboratório, visando o estudo de diversas propriedades de materiais não saturados, que levam em consideração a sucção.

Segundo Holtz (1983), os danos econômicos causados pela variação volumétrica dos materiais geológicos na América do Norte, em 1982, foram calculados em 6.000 
milhões de dólares, superando os danos causados pelo efeito combinado de sismos, tornados, furacões e inundações.

No Brasil, as formações expansivas mais importantes e conhecidas são as integrantes das Bacias Sedimentares do Recôncavo Baiano, do Paraná e Rio Grande do Sul (Simões, 1987). Segundo Costa Nunes (1978), na Bahia são representadas pelas Formações do Grupo Ilha e Santo Amaro e pelo Membro médio da Formação São Sebastião. Em São Paulo, Paraná, Santa Catarina e Rio Grande do Sul, pelas Formações Taubaté, Guabirotuba, Morro Pelado e, Rosário do Sul/ Estrada Nova, respectivamente.

A esse respeito, segundo Felipe (1999), os materiais argilosos da Formação Guabirotuba nas condições em que se encontram na natureza, recobertos pelo solo residual ou transportado, mantém-se com sua umidade natural e não manifestam nenhuma instabilidade. Caso a camada de solo venha a ser retirada, seja na abertura de uma estrada, em loteamentos ou na extração como material de empréstimo, esta argila exposta perde água e se retrai, apresenta empastilhamento e trincas características. Com a água da chuva a argila se re-hidrata, expande e desagrega, formando um leito centimétrico, por toda a superfície exposta, de partículas finas.

Segundo Kormann (2002), estes materiais quando escavados, podem tornar-se potencialmente instáveis, não sendo incomuns acidentes, envolvendo perdas humanas e materiais. Em obras subterrâneas, cuidados especiais fazem-se necessários para evitar desmoronamentos. Taludes de corte mostram-se instáveis, mesmo com inclinações reduzidas como 1:3 ou 1:4. Em Curitiba e região, estacas escavadas e tubulões aparecem como soluções usuais de fundações, porém, é comum o desprendimento de blocos do material, fato que traz sérios riscos à implantação desses elementos.

Pereira e Pejon (1999) realizaram uma avaliação inicial das características expansivas dos materiais provenientes desta Formação na área do Alto Iguaçu - PR., a partir de trabalhos de campo, ensaios laboratoriais e trabalhos anteriormente realizados, verificando a relação entre o teor de umidade inicial e a expansibilidade destes materiais. No desenvolvimento da pesquisa constatou-se uma série de dificuldades no estudo destes materiais, devido à complexidade dos fenômenos que conduzem a expansão. Desta forma, tornou-se evidente a necessidade de implementar estudos mais detalhados para buscar esclarecer melhor a importância dos vários atributos no comportamento da expansão e desagregação destes materiais quando expostos a variações de umidade. Verificou-se por exemplo o efeito marcante da secagem sobre o comportamento desses materiais. 
Ampliando esse estudo, foram selecionados materiais sedimentares expansivos da Formação Guabirotuba, pertencente à Bacia de Curitiba, presentes na área do Alto Iguaçu - PR. Foram escolhidos cinco pontos para realização de um estudo mais detalhado, levando-se em conta locais representativos das variações litológicas dos materiais sedimentares e que apresentaram maior potencial à expansão. Desses pontos, foram retirados cinco amostras de materiais argilosos indeformados, nos quais foram realizados uma série de ensaios, visando estudar a expansibilidade a partir de ensaios edométricos convencionais e sob sucção controlada, aliados a métodos como a Difração de Raios-X, Análise Térmica Diferencial (ATD), Análise Térmica Gravimétrica (ATG), Porosimetria por Intrusão de Mercúrio, Adsorção de Azul de Metileno e Microscopia Eletrônica de Varredura (MEV), que permitiram uma melhor avaliação dos materiais ensaiados.

Foram também obtidas as Curvas de Retenção de Água para estes materiais, cujo objetivo principal foi determinar a variação da sucção matricial e total em função do teor de umidade. A capacidade de retenção de água desses materiais foi avaliada mediante três métodos utilizados na Mecânica dos Solos Não Saturados, denominadas de técnicas do Papel Filtro, da Câmara de Pressão de Richards e Dessecador de vácuo. A partir dos resultados obtidos através das duas primeiras técnicas, foi possível realizar uma comparação entre os resultados experimentais, a fim de observar quais foram mais representativos dos materiais argilosos ensaiados. Os resultados foram ajustados por regressão mediante curvas obtidas através de seis equações matemáticas propostas por Farrel e Larson (1972), Simmons et al. (1979), Libardi et al. (1979), Van Genuchten (1980), Driessen (1986) e Fredlund et al. (1994).

Com base nos ensaios realizados e nos dados obtidos, foi possível fazer uma caracterização destes materiais, com a finalidade de avaliar alguns mecanismos que influenciam no seu comportamento. Os resultados foram interpretados para cada método de ensaio obtendo-se informação sobre as diversas propriedades destes materiais, que também foram relacionados, visando estabelecer a influência destas no potencial expansivo dos materiais aqui estudados.

\subsection{JUSTIFICATIVAS E OBJETIVOS}

A região do Alto Iguaçu é uma área em franca expansão e desenvolvimento urbano, com afluxo de indústrias e necessidade crescente de infra-estrutura. Segundo 
dados do senso realizado pelo IBGE em 2002, somente no município de Curitiba - PR, a população dobrou nos últimos 30 anos, chegando à cerca de 1,6 milhões de habitantes. Assim sendo, este trabalho justifica-se devido aos danos econômicos e sociais associados à expansão dos materiais sedimentares da Formação Guabirotuba, que por constituírem a Bacia Sedimentar de Curitiba, são freqüentes na região, que apresenta um alto índice de ocupação urbana.

Este estudo visa dar continuidade à avaliação da expansibilidade dos materiais sedimentares da Formação Guabirotuba presentes na área do Alto Iguaçu - PR, já iniciado durante a realização do programa de mestrado de Pereira (1999), no qual o objetivo principal foi elaborar uma carta indicando as áreas com maiores potenciais a expansão. Devido às dificuldades no entendimento do comportamento destes materiais frente ao fenômeno de expansão, decidiu-se dar continuidade ao trabalho inicial, discriminando pontos na área, que haviam apresentado um alto potencial à expansão e que representassem litologicamente todos os materiais anteriormente avaliados.

A caracterização mais detalhada destes materiais auxilia e reforça no conhecimento atual dos mecanismos que influenciam na expansibilidade dos mesmos. Pesquisas anteriores, como Pereira (1999), mostraram que o fenômeno depende de inúmeros fatores externos e internos, o que foi detectado pela difícil correlação entre os diversos ensaios realizados. Houve a necessidade para seu esclarecimento de outros estudos, entre eles a estrutura das argilas e de como o material se comporta quando sujeito a modificações volumétricas causadas pela variação da umidade, que está intimamente relacionada com a sucção do material quando parcialmente saturado. Estas variações volumétricas criam pressões indesejáveis podendo comprometer as estruturas das obras de engenharia, causando danos, colocando-as em risco, trazendo transtornos à população e gerando altos custos para a manutenção destas obras. Portanto, isto sugere um aprofundamento contínuo das suas causas, devido aos problemas relativos à expansibilidade dos materiais argilosos presentes na região do Alto Iguaçu - PR.

De acordo com o exposto acima, o objetivo principal deste trabalho é caracterizar a expansibilidade dos materiais sedimentares da Formação Guabirotuba, baseada na avaliação de diferentes mecanismos influentes (mineralogia, textura do solo, estrutura, índices físicos, limites de consistência, características físico-químicas, histórico de tensões, pressão de expansão, bem como, a sucção do solo) e que permitiram observar a importância de cada um deles e sua inter-relação no comportamento expansivo desses materiais. 


\section{CAPÍTULO 2. REVISÃO BIBLIOGRÁFICA}

\subsection{INSTABILIDADE VOLUMÉTRICA EM MATERIAIS EXPANSIVOS}

\subsubsection{Considerações Gerais}

O termo "material expansivo" é utilizado para referir-se àqueles materiais que possuem na sua constituição preferencialmente argilominerais com estrutura laminar potencialmente instáveis, tais como a montmorilonita, vermiculita, clorita e interestratificados. São materiais que possuem limites de liquidez elevados e alta plasticidade. Quando secos são duros, mas perdem facilmente sua resistência quando absorvem água (Presa, 1984).

São inúmeros os trabalhos realizados buscando caracterizar o fenômeno da variação volumétrica em solos e rochas, devido aos problemas causados por estas modificações. Por variação volumétrica entende-se a expansão ou contração do material devido ao ganho ou perda de água, respectivamente.

A expansibilidade dos argilominerais é um dos fatores mais importantes que influenciam o comportamento dos materiais argilosos em solos e a durabilidade dos materiais rochosos. Conseqüentemente, está associada a danos em obras de engenharia, podendo colocá-las em risco, causando degradações rápidas e importantes, como o aparecimento de trincas e rachaduras nas construções, rupturas de aterros e taludes de corte, destruição de obras de contenção, trincas e danos nos pavimentos, desabamentos em túneis, etc; além do alto custo para manutenção das obras. 
As rochas expansivas, quando sujeitas às variações de umidade, devido à exposição às intempéries, sofrem uma desagregação física intensa, desintegrando-se superficialmente em pequenos blocos (empastilhamento), sendo que, quando em contato com a água, vão tornando-se novamente plásticas, o que demonstra a alteração rápida de suas propriedades, o que gera entre outros problemas a instabilidade de taludes, já que os blocos tendem a desprender-se do maciço e a se acumularem no pé do talude (Campos, 1989).

Pode-se dizer, de forma geral, que em maior ou menor escala todos os solos são expansivos quando a tensão efetiva entre suas partículas é reduzida por uma razão qualquer, embora se costume admitir como solos expansivos aqueles que apresentam expansões superiores a $1 \%$, sendo que essa variação volumétrica deve-se apenas à alteração do teor de umidade, sem qualquer variação nas cargas aplicadas (Costa Nunes, 1978).

Os argilominerais são constituintes importantes dos solos, sedimentos e rochas sedimentares. Em escala mundial, os sedimentos e as rochas sedimentares argilosas, constituem cerca de $60 \%$ dos materiais geológicos da coluna estratigráfica e na sua composição os argilominerais participam em cerca de 75\% (Gomes, 1986).

\subsubsection{Principais Características dos Argilominerais}

“Os argilominerais são basicamente silicatos hidratados de $\mathrm{Al}$ e/ou $\mathrm{Fe}$ e $\mathrm{Mg}$, podendo conter ainda, como componentes essenciais um certo teor de elementos alcalinos ou alcalinos-terrosos" (Santos, 1989).

Estes minerais apresentam uma estrutura cristalina definida, cujos átomos estão dispostos em lâminas (Badillo e Rodriguéz, 1988).

Os argilominerais pertencem à classe dos filossilicatos e organizam-se em folhas e camadas, sendo constituídos pela alternância de unidades compostas por tetraédros de oxigênio e silício ou alumínio e octaédros de oxigênio ou $\mathrm{OH}^{-}$com o centro ocupado por cátions como $\mathrm{Al}^{3+}, \mathrm{Fe}^{3+}, \mathrm{Mg}^{2+}, \mathrm{Fe}^{2+}$ e, mais raramente $\mathrm{Ni}^{2+}$ (Grim, 1962).

As folhas tetraédricas são constituídas por um átomo de silício com quatro átomos de oxigênio ou grupos de hidroxilas, caso seja necessário equilibrar a estrutura. Os tetraedros formam um arranjo hexagonal, que repete-se indefinidamente, formando uma camada de composição $\mathrm{Si}_{4} \mathrm{O}_{6}(\mathrm{OH})_{4}(\mathrm{Grim}, 1953)$. 
As folhas octaédricas são constituídas por um plano de cátions entre dois planos de hidroxilas ou oxigênio. Cada cátion é coordenado por seis hidroxilas, que se dispõem nos vértices de um octaédro. A partilha das hidroxilas ou oxigênio pelos octaédros vizinhos geram um arranjo hexagonal de unidades que se repetem formando uma camada (Grim, 1953).

A divisão dos grupos em subgrupos dioctaédricos e trioctaédricos é feita com base na valência do cátion presente nas folhas octaédricas das camadas estruturais. As folhas são dioctaédricas quando dois terços das posições disponíveis são ocupadas por cátions trivalentes, e trioctaédricas quando todas as posições estão ocupadas por cátions bivalentes.

Segundo a nomenclatura recomendada pela Association Internationale pour l’Étude des Argiles (Jeremias, 1991), os argilominerais são constituídos pelo agrupamento de átomos na forma de folhas, que se combinam em camadas. O conjunto de camadas estruturais básicas e dos espaços intercamadas que se repetem, são denominados unidades estruturais. Desta forma, a estrutura dos argilominerais resulta da combinação do empilhamento das folhas tetraédricas de silício (Figura 01) e dos octaédros de alumínio ou magnésio (Figura 02).

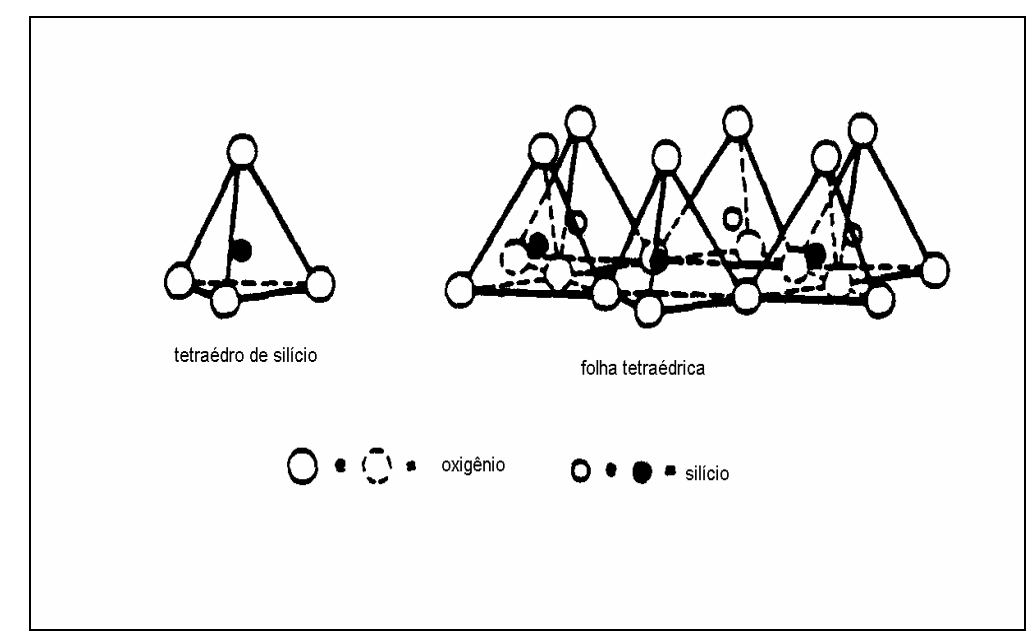

FIGURA 01. Esquema de uma folha tetraédrica de silício e oxigênio (Grim, 1962). 


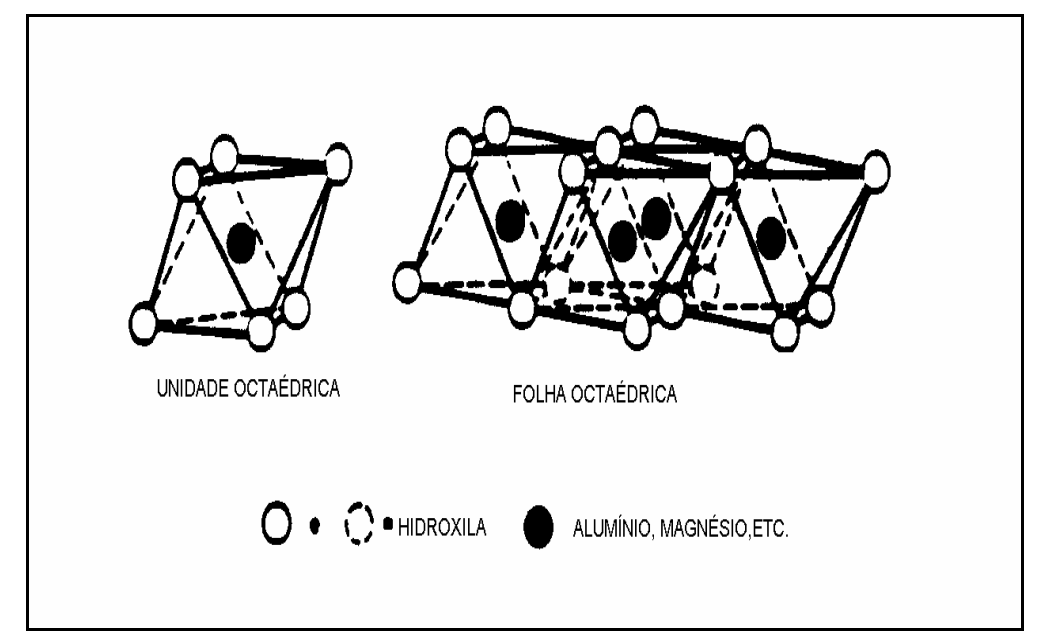

FIGURA 02. Esquema de uma folha octaédrica (Grim, 1962).

\subsubsection{Grupos de Argilominerais}

Os silicatos em camadas podem ser agrupados em arranjos 1:1, 2:1, 2:1:1, referindo-se ao número de tetraedros de $\mathrm{SiO}_{2}$ e de octaédros de hidróxidos, que formam a célula unitária do argilomineral (Tabela 01 ). 
TABELA 01. Sistemática dos Minerais Argilosos (Gomes, 1986)

\begin{tabular}{|c|c|c|c|}
\hline \multicolumn{4}{|c|}{$\begin{array}{l}\text { I-MINERAIS CRISTALINOS } \\
\text { (A) ESTRUTURA EM CAMADAS }\end{array}$} \\
\hline $\begin{array}{l}\text { Tipo ou arranjo das } \\
\text { camadas }\end{array}$ & $\begin{array}{l}\text { Grupo (carga elétrica/ } \\
\text { fórmula unitária) }\end{array}$ & $\begin{array}{l}\text { Sub-grupo } \\
\text { Tri-trioctaédrico } \\
\text { Di-dioctaédrico }\end{array}$ & Espécies \\
\hline \multirow{8}{*}{$2: 1$} & \multirow[b]{2}{*}{ Pirofilita - Talco $(\mathrm{x} \sim 0)$} & Tri & Talco $\quad \mathrm{Mg}_{3} \mathrm{Si}_{4} \mathrm{O}_{10}(\mathrm{OH})_{2}$ \\
\hline & & $\mathrm{Di}$ & Pirofilita $\quad \mathrm{Al}_{2} \mathrm{Si}_{4} \mathrm{O}_{10}(\mathrm{OH})_{2}$ \\
\hline & \multirow{2}{*}{ Esmectitas $(0.2<\mathrm{x}<0.6)$} & Tri & $\begin{array}{ll}\text { Saponita } & \mathrm{E}_{0.33} \mathrm{Mg}_{3}\left(\mathrm{Si}_{3.67} \mathrm{Al}_{0.33}\right) \mathrm{O}_{10}(\mathrm{OH})_{2} \cdot \mathrm{nH}_{2} \mathrm{O} \\
\text { Hectorita } & \mathrm{E}_{0.33}\left(\mathrm{Mg}_{2.67} \mathrm{Li}_{0.33}\right) \mathrm{Si}_{4} \mathrm{O}_{10}(\mathrm{OH})_{2} \mathrm{nH}_{2} \mathrm{O} \\
\text { Stevensita } & 2 \mathrm{E}_{2 \mathrm{x}} \mathrm{Mg}_{3-\mathrm{x}} \mathrm{Si}_{4} \mathrm{O}_{10}(\mathrm{OH})_{2}\end{array}$ \\
\hline & & $\mathrm{Di}$ & $\begin{array}{lcl}\text { Montmorilonita } & \mathrm{E}_{0.33}\left(\mathrm{Al}_{1.67} \mathrm{Mg}_{0.33}\right) \mathrm{Si}_{4} \mathrm{O}_{10}(\mathrm{OH})_{2} \cdot \mathrm{nH}_{2} \mathrm{O} \\
\text { Beideleita } & \mathrm{E}_{0.33} \mathrm{Al}_{2}\left(\mathrm{Si}_{3.67} \mathrm{Al}_{0.33}\right) \mathrm{O}_{10}(\mathrm{OH})_{2} \mathrm{nH}_{2} \mathrm{O} \\
\text { Nontronita } & \mathrm{E}_{0.33} \mathrm{Fe}^{3+}{ }_{2}\left(\mathrm{Si}_{3.67} \mathrm{Al}_{0.33}\right) \mathrm{O}_{10}(\mathrm{OH})_{2} \mathrm{nH}_{2} \mathrm{O}\end{array}$ \\
\hline & \multirow[t]{2}{*}{ Vermiculitas $(0.6<\mathrm{x}<0.9)$} & Tri & $\begin{array}{l}\text { Vermiculita } \mathrm{E}_{0.86}\left(\mathrm{Mg}, \mathrm{Fe}^{2+}, \mathrm{Fe}^{3+}, \mathrm{Al}\right)_{3}(\mathrm{SiAl})_{4} \mathrm{O}_{10}(\mathrm{OH})_{2} \\
\mathrm{nH}_{2} \mathrm{O}\end{array}$ \\
\hline & & $\mathrm{Di}$ & Vermiculita $\quad \mathrm{E}_{0.86} \mathrm{Al}_{2}\left(\mathrm{Si}, \mathrm{Al}_{4}\right) \mathrm{O}_{10}(\mathrm{OH})_{2} \mathrm{nH}_{2} \mathrm{O}$ \\
\hline & \multirow[b]{2}{*}{ Micas $(\mathrm{x} \sim 1)$} & Tri & $\begin{array}{ll}\text { Flogopita } & \mathrm{KMg}_{3}\left(\mathrm{Si}_{3} \mathrm{Al}\right) \mathrm{O}_{10}(\mathrm{OH})_{2} \\
\text { Biotita } & \mathrm{K}\left(\mathrm{Mg}, \mathrm{Fe}^{2+}, \mathrm{Fe}^{3+}, \mathrm{Mn}\right)_{3}(\mathrm{Si} \mathrm{Al}) \mathrm{O}_{10}(\mathrm{OH})_{2} \\
\text { Lepidolita } & \mathrm{K}(\mathrm{Al}, \mathrm{Li})_{3}(\mathrm{Si}, \mathrm{Al})_{4} \mathrm{O}_{10}(\mathrm{OH})_{2}\end{array}$ \\
\hline & & Di & $\begin{array}{ll}\text { Muscovita } & \mathrm{K} \mathrm{Al}_{2}\left(\mathrm{Si}_{3} \mathrm{Al}\right) \mathrm{O}_{10}(\mathrm{OH})_{2} \\
\text { Paragonita } & \mathrm{Na} \mathrm{Al}_{2}\left(\mathrm{Si}_{3} \mathrm{Al}\right) \mathrm{O}_{10}(\mathrm{OH})_{2} \\
\text { Ilita } & \mathrm{K}_{\mathrm{x}}(\mathrm{Al}, \mathrm{Mg})_{2}(\mathrm{Si}, \mathrm{Al})_{4} \mathrm{O}_{10}(\mathrm{OH})_{2} \cdot \mathrm{nH}_{2} \mathrm{O}(\mathrm{x}<1)\end{array}$ \\
\hline \multirow[b]{2}{*}{$2: 1: 1$} & \multirow[b]{2}{*}{ Cloritas (x variável) } & Tri & $\begin{array}{ll}\text { Mg-Clorita (clinocloro) } & \left(\mathrm{Mg}_{5} \mathrm{Al}\right)\left(\mathrm{Si}_{3} \mathrm{Al}\right) \mathrm{O}_{10}(\mathrm{OH})_{8} \\
\text { Fe-Clorita (charmosita) } & \left(\mathrm{Fe}^{2+}{ }_{5} \mathrm{Al}\right)\left(\mathrm{Si}_{3} \mathrm{Al}\right) \mathrm{O}_{10}(\mathrm{OH})_{8}\end{array}$ \\
\hline & & $\mathrm{Di}$ & $\begin{array}{lr}\text { Al-Clorita (sudoita) } & \left(\mathrm{Mg}_{3{ }^{-}{ }_{x}} \mathrm{Al}_{2-{ }^{-}}\right)\left(\mathrm{Si}_{4{ }^{-}} \mathrm{Al}_{\mathrm{x}}\right) \mathrm{O}_{10}(\mathrm{OH})_{8} \\
\text { Al Li-Clorita (cookeita) } & \left(\mathrm{Al}_{4} \mathrm{Li}\right)\left(\mathrm{Si}_{3} \mathrm{Al}\right) \mathrm{O}_{10}(\mathrm{OH})_{8}\end{array}$ \\
\hline \multirow{2}{*}{$1: 1$} & \multirow{2}{*}{$\begin{array}{l}\text { Caulinita-Serpentina } \\
\qquad(\mathrm{x} \sim 0)\end{array}$} & Tri & $\begin{array}{lr}\text { Mg-Serpentina (antigorita, crisótilo) } & \mathrm{Mg}_{3} \mathrm{Si}_{2} \mathrm{O}_{5}(\mathrm{OH})_{4} \\
\text { Mg-Al serpentina(amesita) } & \left(\mathrm{Mg}_{2} \mathrm{Al}\right)\left(\mathrm{SiAl}^{3+} \mathrm{O}_{5}(\mathrm{OH})_{4}\right. \\
\text { Fe-serpentina (cronstedita) } & \left(\mathrm{Fe}^{+2}{ }_{2} \mathrm{Fe}^{3+}\right)\left(\mathrm{SiFe}^{3+}\right) \mathrm{O}_{5}(\mathrm{OH})_{4}\end{array}$ \\
\hline & & Di & $\begin{array}{ll}\text { Caulinita, diquita, nacrita } & \mathrm{Al}_{2} \mathrm{Si}_{2} \mathrm{O}_{5}(\mathrm{OH})_{4} \\
\text { Haloisita (7A) } & \mathrm{Al}_{2} \mathrm{Si}_{2} \mathrm{O}_{5}(\mathrm{OH})_{4} \\
\text { Haloisita (10A) } & \mathrm{Al}_{2} \mathrm{Si}_{2} \mathrm{O}_{5}(\mathrm{OH})_{4} \cdot 2 \mathrm{H}_{2} \mathrm{O} \\
\end{array}$ \\
\hline \multicolumn{4}{|c|}{ (B) Estrutura em pseudo-camadas (fitas) } \\
\hline & & & $\begin{array}{l}\mathrm{Mg}_{2} \mathrm{Si}_{12} \mathrm{O}_{30}(\mathrm{OH})_{4}\left(\mathrm{OH}_{2}\right)_{4} 8 \mathrm{H}_{2} \mathrm{O} \\
\mathrm{Mg}_{2} \mathrm{Si}_{8} \mathrm{O}_{20}(\mathrm{OH})_{2}\left(\mathrm{OH}_{2}\right)_{4} 4 \mathrm{H}_{2} \mathrm{O}\end{array}$ \\
\hline \multicolumn{4}{|c|}{ II - MINERAIS NÃO CRISTALINOS OU FRACAMENTE CRISTALINOS } \\
\hline & & & $\begin{array}{l}1 \sim 2 \mathrm{SiO}_{2} \cdot \mathrm{Al}_{2} \mathrm{O}_{3} \cdot \mathrm{nH}_{2} \mathrm{O} \\
1 \sim 1.5 \mathrm{SiO}_{2} \cdot \mathrm{Al}_{2} \mathrm{O}_{3} \cdot 2 \sim 3 \mathrm{H}_{2} \mathrm{O}\end{array}$ \\
\hline
\end{tabular}

\subsubsection{Grupo das Caulinitas (1:1)}

O grupo das caulinitas apresenta camadas do tipo 1:1, que resultam da combinação de uma folha tetraédrica com uma folha octaédrica, que se superpõem indefinidamente (Figura 03). 


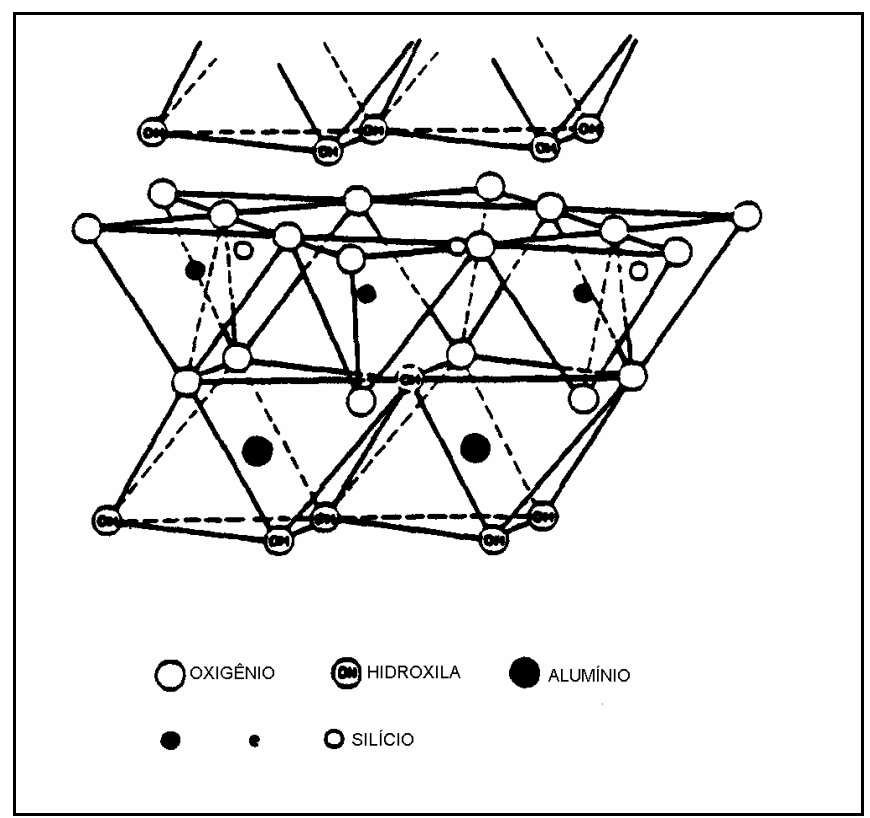

FIGURA 03. Esquema estrutural de base de uma caulinita (Grim, 1962).

As camadas estruturais ligam-se entre si, por pontes de hidrogênio entre átomos $\mathrm{O}^{2-}$ e por grupos $\mathrm{OH}^{-}$de planos atômicos justapostos (Gomes, 1986). Segundo Grim (1953), a fórmula estrutural da caulinita é representada por $(\mathrm{OH})_{8} \mathrm{Si}_{4} \mathrm{Al}_{4} \mathrm{O}_{10}$.

Os minerais deste grupo são pouco expansivos, porque não ocorre hidratação das camadas estruturais, devido à distância reticular ser muito pequena e a pouca adsorção superficial. A adsorção superficial é incipiente, devido à estrutura ser quase eletricamente neutra, por não ocorrer ou ocorrer muito pouca substituição isomórfica. Podem existir pequenas substituições de $\mathrm{Al}$ por Fe e/ou Ti nas variedades relativamente menos cristalinas (Grim, 1962). Como conseqüência, os argilominerais deste grupo são relativamente estáveis na presença de água. Os minerais do grupo da caulinita apresentam baixa capacidade de troca catiônica, da ordem de 1 a 10 meq/100g (Gillott, 1987).

A caulinita é o argilomineral mais comum em solos residuais maduros, por ser estável, não caracteriza o solo como problemático, principalmente quanto à característica de plasticidade e expansão (solo medianamente plástico e com comportamento não expansivo) (Carvalho, 1997). 


\subsubsection{Grupo das Esmectitas (2:1)}

O grupo das esmectitas é formado pelo empilhamento de camadas compostas por uma folha octaédrica intercalada a duas folhas tetraédricas (Figura 04).

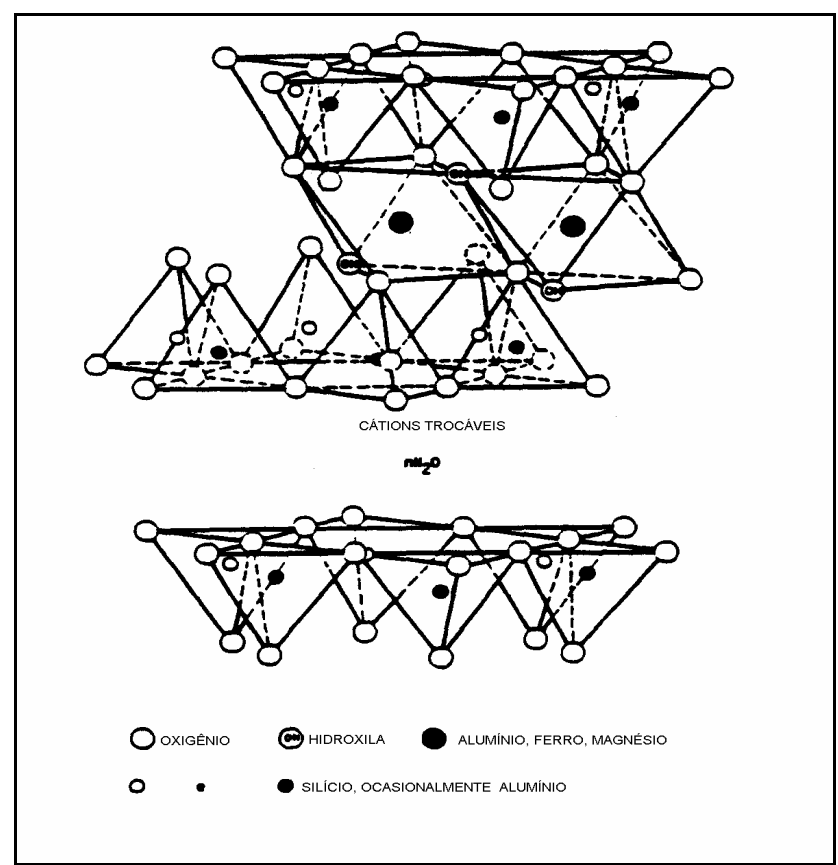

FIGURA 04. Esquema estrutural de base de uma montmorilonita (Grim, 1962).

As esmectitas se distinguem, pelo fato de apresentarem expansibilidade intracristalina, devido à água e líquidos orgânicos penetrarem entre as camadas. Pode também haver contração resultante da desidratação (Deer et al., 1966).

De acordo com Olphen (1963), a expansibilidade intracristalina das esmectitas pode ser explicada pela:

- Hidratação dos cátions existentes entre as camadas estruturais pelas moléculas polares de água, diminuindo a força atrativa das camadas.

- Adsorção de moléculas de água na superfície das camadas formadas por oxigênio, estabelecendo ligações de hidrogênio.

As maiores variações volumétricas nas esmectitas devem-se a expansibilidade osmótica que em condições particulares de confinamento, podem levar a pressões de expansão (pressão osmótica) elevadas. 
A montmorilonita é a principal espécie das esmectitas, que são representadas ainda pelas saponitas, ricas em $\mathrm{Mg}$, hectoritas, ricas em Li e Mn, nontronita, rica em Fe e beidelita, rica em Al, e apresenta forte tendência à instabilidade na presença de água.

$\mathrm{Na}$ Figura 05, pode-se observar um esquema da absorção de água entre as camadas estruturais de uma montmorilonita.

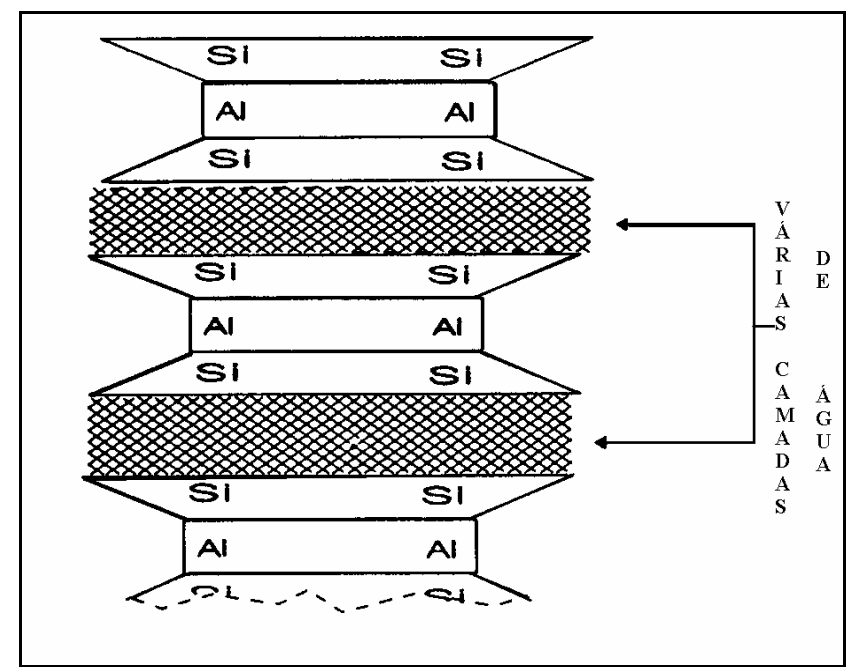

FIGURA 05. Representação esquemática da estrutura típica de uma montmorilonita (Yong et al., 1992).

Nas montmorilonitas, quando $\mathrm{o} \quad \mathrm{Ca} \quad \mathrm{e} \quad \mathrm{o} \quad \mathrm{Mg}$ são os cátions trocáveis predominantes, a expansão é menor, pois esta aumenta com a diminuição da valência do cátion.

As partículas da montmorilonita são muito pequenas e finas, tendo uma grande área específica (podendo atingir $800 \mathrm{~m}^{2} / \mathrm{g}$ ), possuindo, portanto, uma elevada plasticidade e um comportamento coloidal (Carvalho, 1997). A capacidade de troca de cátions do grupo é da ordem de 80 - 150 meq/100g (Mitchell, 1976).

\subsubsection{Grupo das Micas (2:1)}

\section{a) Ilita}

As ilitas pertencem ao grupo das micas e são constituídas por uma folha octaédrica intercalada a duas folhas tetraédricas, sendo as camadas estruturais ligadas 
por cátions monovalentes, normalmente $\mathrm{K}^{+}$. Apresenta uma estrutura semelhante a das micas (Figura 06), com um espaçamento basal de 1,0 nm (Grim, 1962).

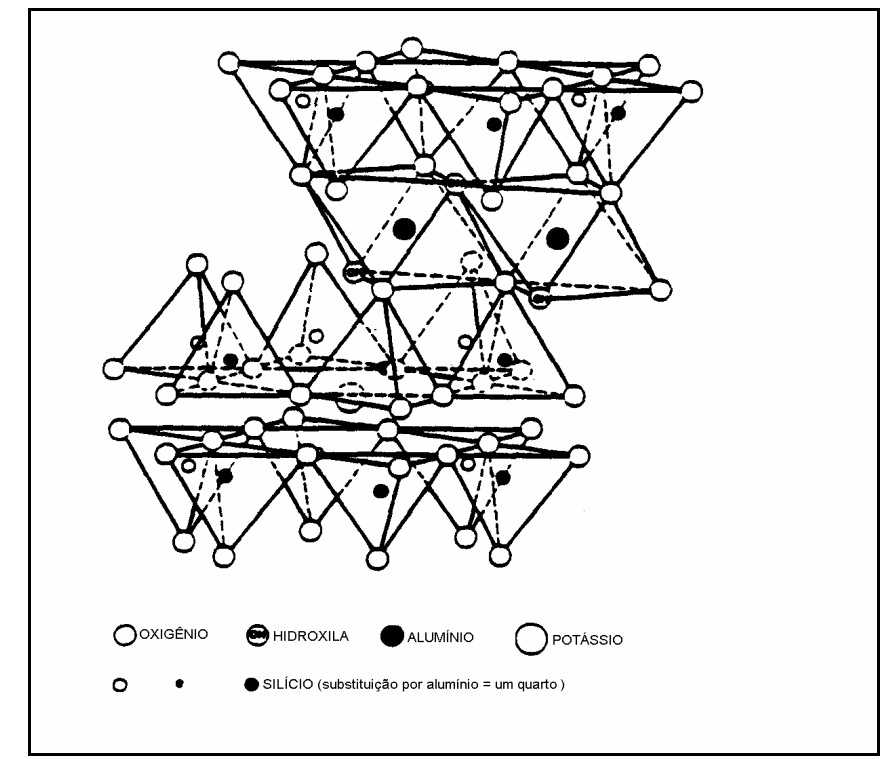

FIGURA 06. Esquema estrutural da muscovita. A estrutura da ilita é semelhante (Grim, 1962).

A principal diferença da ilita para a montmorilonita, é que a primeira não apresenta expansibilidade intracristalina, devido à forte ligação iônica gerada pelos íons $\mathrm{K}^{+}$entre as camadas estruturais. Apesar disto, na montmorilonita $\mathrm{K}^{+}$ocorre expansibilidade intracristalina, pelo número menor de íons potássio e pela carga negativa estar localizada na folha octaédrica, e por isso, a maior distância dos íons $\mathrm{K}^{+}$, originando forças eletrostáticas mais fracas (Olphen, 1963).

Segundo Gomes (1986), a ilita possui maior carga elétrica negativa por unidade de superfície do que a montmorilonita, e a carga negativa da ilita está localizada na folha tetraédrica, ou seja, mais próxima dos cátions intercalares. Ao contrário, na montmorilonita a carga está mais concentrada na folha octaédrica. Assim, as forças estruturais intercamadas na ilita são mais fortes, e a água e outros líquidos polares dificilmente podem penetrar entre aquelas camadas.

A ilita somente manifesta sensibilidade a água em condições de extrema degradação, e esta ocorre devido a perda de íons $\mathrm{K}^{+}$das arestas expostas da partícula, tornando-a muito plástica. A capacidade de troca de cátions do grupo é da ordem de 10 40 meq/100g (Mitchell, 1976). 


\subsubsection{Grupo da Clorita $(2: 1: 1)$}

O grupo das cloritas apresenta camadas do tipo 2:1 regularmente intercaladas com uma folha octaédrica (folha intercamada), onde o cátion coordenado pelas hidroxilas é normalmente o $\mathrm{Mg}^{2+}$, podendo ser o $\mathrm{Fe}^{2+}$ ou o $\mathrm{Al}^{3+}$ e menos frequentemente o $\mathrm{Li}^{+}$ (Gomes, 1986).

Possuem um espaçamento basal de 1,4 nm (Grim, 1962). Podem ser dioctaédricas, ditrioctaédricas e mais frequentemente trioctaédricas.

De acordo com Gillott (1987), a capacidade de troca de cátions das cloritas é pequena, na ordem de 10 a 40 meq/100g. Algumas cloritas denominadas "cloritas expansivas", quando tratadas com glicerol, mostram um aumento do espaçamento basal, que normalmente é de $1,4 \mathrm{~nm}$.

\subsubsection{Grupo da Vermiculita $(2: 1)$}

O grupo da vermiculita possui uma expansão mais limitada que a montmorilonita na presença de água e outras moléculas polares. Segundo Carcedo et al. (1986), a vermiculita têm uma capacidade expansiva pouco menor que a montmorilonita na presença de cátions bivalentes, sendo que para cátions monovalentes é variável, semelhante no caso do $\mathrm{Li}^{+}$, muito inferior para o $\mathrm{Na}^{+}$e inexistente para o $\mathrm{K}^{+}$. O espaçamento basal do grupo é de $14 \mathrm{~nm}$, podendo variar de acordo com o cátion de troca e do estado de hidratação do cristal (Frazão e Goulart, 1976).

A capacidade de troca catiônica é elevada, estando na faixa de 100 a 150 meq por $100 \mathrm{~g}$ de vermiculita (Mitchell, 1993). Valores inferiores a $100 \mathrm{meq} / 100 \mathrm{~g}$ têm sido relacionados, porém não se trata de vermiculitas monominerálicas e sim de camadas mistas interestratificadas contendo vermiculita (Santos, 1992).

\subsubsection{Grupo dos Interestratificados}

Outro grupo de argilominerais que pode tornar o solo potencialmente expansivo são os interestratificados. Devido à semelhança entre as estruturas básicas, pode ocorrer a intercalação de mais de um tipo de argilomineral, sendo que os que ocorrem com maior freqüência são: montmorilonita-clorita, montmorilonita-ilita, clorita-vermiculita, 
ilita-vermiculita-ilita e vermiculita-clorita. Os interestratificados que apresentam maior potencial expansivo são os de montmorilonita - vermiculita.

\subsection{MECANISMOS DE EXPANSÃO ASSOCIADOS ÀS PROPRIEDADES DOS ARGILOMINERAIS}

A mudança de volume dos materiais argilosos expansivos é causada pela combinação de vários mecanismos.

Segundo Taylor e Smith (1986), os mecanismos de expansão podem ser mecânicos e/ou físico-químicos. A expansão mecânica ocorre em resposta às forças de descompressão elásticas e estão relacionadas ao fator tempo; na prática podem ser devidas às escavações feitas pelo homem, à ação dos movimentos tectônicos e a erosão.

De acordo com Gomes (1986), os fatores acima provocam um relaxamento da pressão, que gera uma pressão negativa (sucção) na água dos poros do solo ou do sedimento argiloso, da mesma ordem de grandeza da pressão inicial. O tempo necessário para restabelecer o equilíbrio vai depender da permeabilidade dos materiais.

Segundo Snethen et al. (1977), os mecanismos físico-químicos que determinam o potencial expansivo de um argilomineral são: atração superficial das partículas, hidratação de cátions e repulsão osmótica.

A atração superficial das partículas dos argilominerais é um mecanismo gerado pela magnitude das forças eletrostáticas provenientes das cargas elétricas negativas nas superfícies das partículas dos argilominerais, que tendem a ser compensadas pela atração de cátions que encontram-se em solução na água livre dos poros e particularmente por moléculas polares, como as de água.

Segundo Presa (1984), a influência deste mecanismo na mudança de volume provêm do esforço desenvolvido para neutralizar o desequilíbrio das cargas. Desta forma, a quantidade de água na dupla camada aumentará até que ocorra uma suficiente mudança de volume na massa de solo.

A hidratação ocorre devido às substituições isomórficas e cátions adsorvidos, que originam uma variação de carga e conseqüentemente aumentam a capacidade de atração de moléculas de água (hidratação), ocasionando variações de volume. Este mecanismo influencia na expansibilidade pelo aumento que o raio iônico dos cátions sofrem a medida que vão sendo hidratados, gerando um aumento de volume na massa de solo (Presa, 1984). 
A repulsão osmótica é um mecanismo importante em condições de umidade e concentração iônica elevadas. Ocorre com a entrada de moléculas de água entre as camadas dos argilominerais, devido às diferenças da concentração iônica na dupla camada. A maior concentração ocorre junto à superfície do argilomineral e diminui a medida que se afasta desta superfície. O contato da água com concentrações iônicas diferentes permite o ingresso de água com a finalidade de equilibrar as diferenças de concentrações, resultando num aumento da dupla camada e conseqüentemente no volume do solo.

Segundo Gomes (1986), a expansão físico-química é governada por forças repulsivas entre as partículas dos argilominerais, uma vez que as forças atrativas são muito pequenas, em comparação com a gama das cargas exteriores. As partículas são rodeadas por duplas camadas elétricas, cujas características dependem da carga elétrica global das partículas e dos cátions de troca, que estão em solução na água livre dos poros. A concentração do eletrólito, a valência dos cátions e a temperatura são muito importantes na expansibilidade físico-química. Assim, os cátions monovalentes e em fraca concentração, geram duplas camadas difusas mais amplas, e conseqüentemente, maiores expansões.

De acordo com o mesmo autor, um processo adequado de troca catiônica, pode, em alguns casos, diminuir as propriedades expansivas dos argilominerais e facilitar a estabilidade dos materiais geológicos argilosos. Como exemplo, cita o tratamento com água de cal (hidróxido de cálcio), que pode ser útil na estabilização de argilominerais sódicos.

A propriedade mais importante dos argilominerais expansivos é a capacidade de mudar de volume pela sorção de moléculas de água ou outros íons polares em sua estrutura. Os argilominerais possuem um diâmetro de grãos menores que $2 \mu \mathrm{m}$ e uma forma cristalográfica em folhas. Estes fatores dão ao argilomineral uma área superficial muito grande e estas lhe conferem a propriedade de adsorção de água. Todos os argilominerais atraem água para as suas superfícies, mas somente alguns a conduzem para a sua estrutura interna, Figura 07 (modificado de Velde, 1992).

A hidratação é mais forte quando a carga da unidade estrutural é menor que 1 , como é o caso das esmectitas (montmorilonitas, beidelitas, hectoritas), que tem carga elétrica $Z<0,6$. Nas esmectitas ocorrem variações significativas de hidratação e como conseqüência de volume, pelas variações de carga, que normalmente ocorrem pelas substituições isomórficas e cátions adsorvidos. 


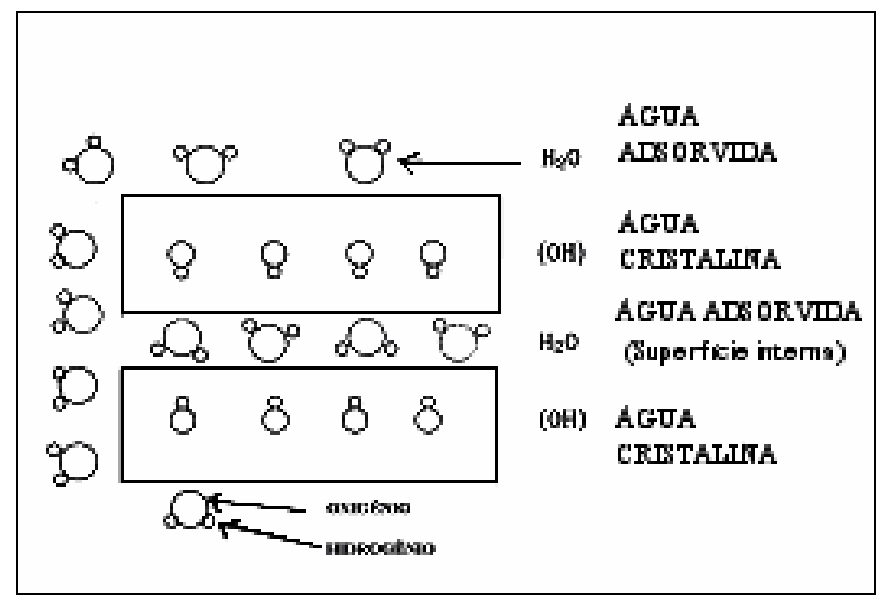

FIGURA 07. Diferentes tipos de água associada com a expansão cristalina (modificado de Velde, 1992).

Os argilominerais têm grandes superfícies com carga negativas, que são compensadas por cátions adsorvidos e pelas moléculas de água orientadas, que representam um papel importante na expansão.

Apesar das espessuras das camadas de água serem semelhantes para os diferentes tipos de argilominerais, a expansão é maior para o grupo das montmorilonitas, devido à sua superfície interna ser mais acessível e as dimensões das partículas menores.

Nas ilitas a hidratação é como nas caulinitas, preferencialmente externa, mas devido às pequenas dimensões das partículas, sua expansão pode ser significativa (Seedsman, 1993).

Segundo este mesmo autor, dependendo do nível de interação entre as moléculas de água e a superfície do argilomineral, haverá ou uma expansão intercamadas essencialmente osmótica, ou estrutural em nível cristalino. A expansão intracristalina ocorre devido às forças atrativas que ligam as camadas estruturais serem menores que as responsáveis pela absorção de água (Gillott, 1987). Assim, a água absorvida forma diversas monocamadas sobre as superfícies dos argilominerais, separando suas partículas ou suas unidades estruturais, Figura 08.

Segundo Jeremias (1991), a absorção de água pelas superfícies internas dos argilominerais é influenciada pelo tipo de cátion intercalar, por exemplo, as montmorilonitas cálcicas absorvem até duas camadas monomoleculares de água, enquanto as montmorilonitas sódicas, podem absorver um número maior. As esmectitas, vermiculita, cloritas expansivas, haloisita e alguns minerais interestratificados apresentam expansibilidade intracristalina. 
A expansão cristalina vai depender, sobretudo da energia livre superficial, ou seja, da afinidade da superfície sólida com a água. Este processo é muito importante nos argilominerais do grupo das esmectitas e praticamente ausente nas argilas que não apresentam cátions intercamadas, como a caulinita, por exemplo (Pejon e Zuquette, 1996).

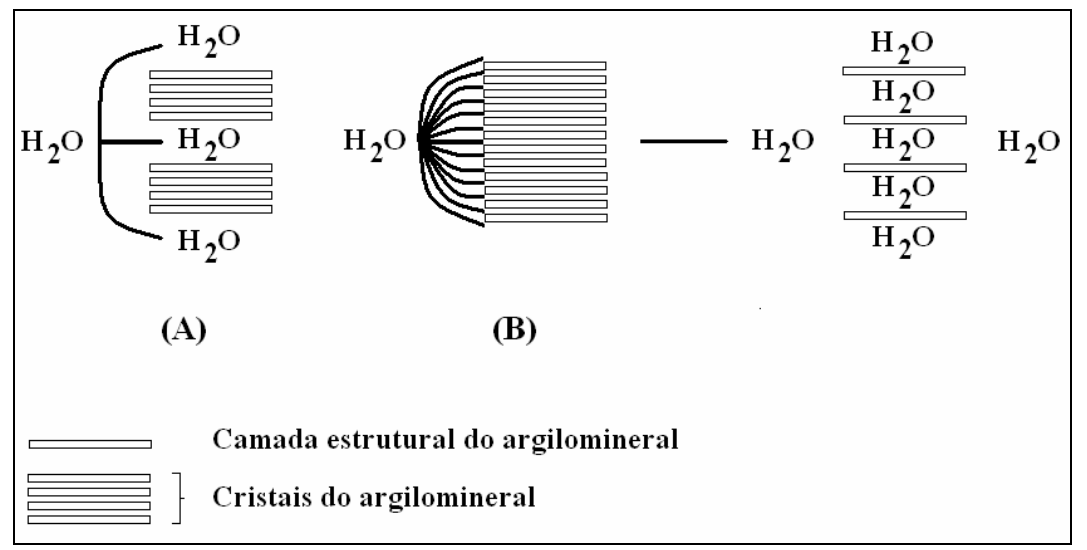

FIGURA 08. Absorção de água por argilominerais: a) adsorção intercristalina de água num argilomineral do tipo 2:1 não expansivo (ilita); b) absorção intracristalina de água num argilomineral do tipo 2:1 expansivo (montmorilonita) (Gillott, 1987).

A expansão osmótica, também chamada expansão da dupla camada elétrica, ocorre com a entrada de moléculas de água entre as camadas dos argilominerais 2:1, principalmente nas montmorilonitas, com íons monovalentes intercamadas.

Segundo Taylor e Smith (1986), a expansão osmótica vai depender do tamanho dos poros, sendo que os poros com menos de $1,5 \mathrm{~nm}$ de diâmetro têm uma maior influência no fenômeno, devido à superposição de duplas camadas elétricas distintas, originando forças repulsivas (Figura 09).

Quando as duplas camadas elétricas estão sobrepostas, devido a concentração de cargas negativas na superfície dos argilominerais e a ligação de camadas de água polarizada, ocorre uma concentração de cátions no espaço entre as placas argilosas. O aumento da concentração provoca um aporte de água para restabelecer o equilíbrio, o que aumenta a expansão, que é denominada expansão osmótica (Jeremias, 1991). 


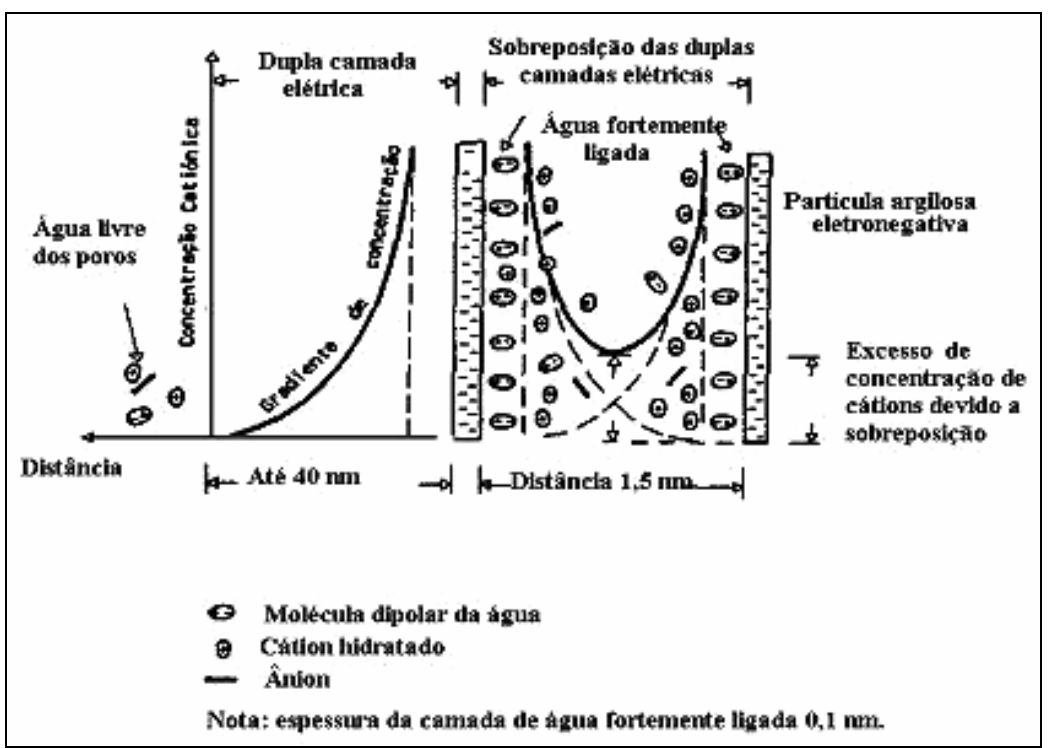

FIGURA 09. Modelo proposto para explicar o mecanismo de expansão osmótica entre duas partículas argilosas (Taylor e Smith, 1986).

A expansão osmótica vai depender da concentração eletrolítica, da temperatura e valência dos cátions e da constante dielétrica. Na prática, cátions monovalentes, com fracas concentrações, formam duplas camadas elétricas mais extensas o que conduz a uma expansão maior. Aumentando a valência e/ou a concentração do cátion, a expansão será menor (Jeremias, 1991).

Segundo Taylor e Smith (1986), os mecanismos de expansão da caulinita são mecânicos, na ilita vai depender do tipo de cátion, nas montmorilonitas sódicas os efeitos da expansão são físico-químicos, e nas cálcicas terá os dois tipos de mecanismos.

\subsection{OUTROS FATORES QUE INFLUENCIAM NA EXPANSÃO}

Quando o material é potencialmente expansivo, a expansão poderá se manifestar quando houver disponibilidade de água, ocorra gradiente que origine sua movimentação ou pela atuação de um ou mais grupos de mecanismos (Simões, 1987).

De acordo com o autor acima, a variação de umidade do material, pela infiltração de águas pluviométricas, é a mais comum, seguida pela elevação do nível do lençol freático, como também em alguns casos o efeito da sua ascensão capilar. Outros mecanismos são os gerados pela ação do homem, como, infiltrações concentradas, 
devido à vazamentos de redes de água e esgoto, existência de fossas e jardins próximos às obras, bem como, fornos, caldeiras, árvores frondosas, etc., que ressecam o solo naquela região, propiciando que se tornem expansivos, devido à baixa umidade inicial resultante.

Segundo Simões (1987), os gradientes devem-se a gravidade (infiltrações e variação do N.A), sucção por capilaridade (zona de ascensão capilar) e osmótica (pelas diferentes concentrações de íons na água), além do gradiente térmico, que origina um fluxo de água nas fases líquidas e gasosas, das zonas mais quentes para as mais frias.

Os mecanismos de expansão podem ser divididos em: deformações elastoplásticas, pelo alívio de carregamentos sobre o material (escavações, erosão, etc.), sendo compostos por deformações instantâneas e dependentes do tempo, em função do descarregamento e tensões iniciais; levantamento de fundo de uma escavação, pela existência de elevadas tensões horizontais "in situ" e hidratação dos argilominerais, devida a capacidade de adsorção de água na superfície externa da partícula e a entrada de moléculas de água na sua estrutura interna (Lindner, 1976 apud Simões, 1987).

As expansões, devido à reações químicas, são provocadas pelo fato de que a alteração de alguns materiais por hidratação, oxidação ou carbonatação geram produtos com volumes maiores que os dos materiais originais. A hidratação é o principal mecanismo e é responsável por grande parte da expansão. As deformações elastoplásticas também são importantes, porque aumentam a capacidade de absorção de água, gerando maiores expansões e conseqüentemente, queda de resistência ao cisalhamento (Lindner, 1976 apud Simões, 1987).

A expansão de um material está fundamentalmente ligada aos seus fatores intrínsecos (Simões, 1987). Estes fatores são aqueles que determinam uma variação de volume em função da variação de umidade e que estão mais intimamente ligados à natureza e arranjo de suas partículas.

De acordo com Nelson e Miller (1992), a magnitude do potencial expansivo é influenciada por diversos fatores que podem ser classificados como: propriedades do material, condições do meio ambiente e do estado de tensões a que se encontra submetido.

Entre os fatores que podem influenciar o processo expansivo podem ser citados:

- Tipo e teor dos argilominerais: é um dos fatores que maior influência têm sobre a expansibilidade de um determinado material, sendo que, vai determinar se o material é ou não potencialmente expansivo. 
Entre os argilominerais que provocam maiores mudanças de volume encontram-se as montmorilonitas, vermiculitas e interestratificados (Snethen et al.,1977);

- O tipo e a concentração de cátions adsorvidos na superfície das partículas dos argilominerais influenciam no grau de mudança de volume, devido às suas propriedades de hidratação.

Quanto maior o raio iônico, maior será a hidratação do íon e conseqüentemente, maior a mudança de volume que ocorrerá (Olphen, 1963). A capacidade expansiva diminui na seguinte ordem: $\mathrm{Na}, \mathrm{K}, \mathrm{Ca}, \mathrm{Mg}, \mathrm{Al}, \mathrm{Cr}$ e Fe (Simões, 1987);

- Tipo e resistência da cimentação: quanto mais fortes entre as partículas, menores as expansões (Simões, 1987);

- Densidade seca: altas densidades secas indicam menores espaços interpartículas e maiores forças de repulsão, o que resulta um maior potencial expansivo (Chen, 1975);

- Macroestrutura do material: presença de trincas, fissuras, descontinuidades, etc., no maciço, relaxam as pressões desenvolvidas pela expansão (Simões, 1987);

- Histórico de tensões: um solo pré-consolidado é mais expansivo do que o mesmo com o mesmo índice de vazios, porém normalmente consolidado (Mitchell, 1976);

- Temperatura: temperaturas crescentes produzem umidade difusa em direção a áreas abaixo de pavimentos e construções (Hamilton, 1969);

- Química da água do solo: a expansão é menor com o acréscimo da concentração e valência de cátions. Por exemplo, cátions de $\mathrm{Mg}^{2+}$ na água do solo podem resultar numa menor expansão do que cátions de $\mathrm{Na}^{+}$(Mitchell, 1976);

- Sucção do solo: solos com maior sucção podem ser mais expansivos, influenciados pelo grau de saturação, tamanho e forma dos poros, tensão superficial, características elétricas e químicas das partículas do solo (Fredlund e Morgenstern, 1977);

- Plasticidade: em geral, solos com comportamento plástico apresentam altos LL e grande potencial expansivo. A plasticidade é um indicador do potencial de expansão (Nelson e Miller, 1992);

- Microestrutura do material: refere-se à orientação espacial e disposição das partículas constituintes do material. Geralmente quanto mais dispersa a estrutura, menor será a expansão do material, ao contrário da floculada, que tende a apresentar maiores expansões (Simões, 1987); 
- Clima: a quantidade e a variação da precipitação e evapotranspiração influenciam na variação do teor de umidade do solo, assim como o nível do lençol freático (Holland e Lawrence, 1980);

- Lençol freático: influencia na contribuição do teor de umidade próximos às camadas de solos expansivos (Nelson e Miller, 1992);

- Vegetação: absorvem a umidade do solo onde encontram-se situados e nas proximidades, causando um diferencial no teor de umidade em relação às áreas não cobertas por esta (Buckley, 1974);

- Permeabilidade: materiais com alta permeabilidade, particularmente devido a fissuras, fendas, trincas, permitem uma condutividade hidráulica maior e portanto, rápidas respostas de expansão (Wise e Hudson, 1971);

- Carregamento: a sobrecarga influencia na mudança do volume para um dado teor de umidade e densidade seca do solo (Holtz, 1959);

- Perfil do solo: a deformação volumétrica será menor se as camadas de solos expansivos encontram-se depositadas sob camadas de materiais não expansivos (Holland e Lawrence, 1980);

- Umidade natural: o conteúdo de água inicial num material pode indicar o grau de expansão que apresentará (Madlun, 1983);

- Espessura da camada expansiva: está diretamente relacionada com a intensidade da expansão e das pressões de levantamento. Quanto mais espessa a camada, maior será a expansão e as pressões de levantamento (Madlun, 1983);

- Profundidade da camada expansiva: caso esteja muito profunda e não seja atingida pelas variações sazonais de umidade, nem receba sobrecargas devido às construções de superfície, pode nunca causar problemas (Madlun, 1983).

\subsubsection{Influência da Textura da Rocha no Processo Expansivo}

Segundo Le Roux (1976), a textura de uma rocha é definida como, a forma, a dimensão e a disposição de um certo número de minerais agrupados em uma população dentro da rocha. Assim, a textura de uma rocha vai estar condicionada às seguintes características: 

a) Grau de cristalinidade;
b) Forma e dimensão das partículas constituintes;
c) Homogeneidade do tamanho das partículas;
d) Homogeneidade do material;
e) Presença ou ausência de ligação entre os minerais;
f) Presença e orientação dos vazios e fraturas.

De acordo com o mesmo autor, as diferentes texturas vão depender das seguintes características:
a) Cristalinidade;
b) O tamanho dos elementos;
c) A disposição;
d) A abundância de ligações entre os minerais;
e) A continuidade do meio.

De acordo com Le Roux (1976), os métodos utilizados para estudo das texturas das rochas são: microscopia ótica, microscopia eletrônica de transmissão e de varredura, além, da difração de Raios-X, que permite determinar o grau de cristalinidade dos minerais.

\subsubsection{Compressão de Ar nos Poros}

Quando ocorre a diminuição da umidade em um solo ou em uma rocha, ocorre a entrada de ar nos poros, que com o retorno da água, pode sofrer uma compressão devido as pressões de sucção. Este é um importante mecanismo de desagregação de solos, por desenvolver tensões que provocam a expansão e desagregação de rochas sedimentares (Terzaghi e Peck (1967) apud Seedsman (1993)).

Segundo Seedsman (1993), estas tensões ocorrem sob a forma de pressões capilares e estão relacionadas à tensão superficial do fluido (geralmente água), e ao tamanho dos poros, podendo ser determinada pela equação abaixo:

$\mathrm{P}=2 \mathrm{~s} / \mathrm{r}=\ln \left(\mathrm{p} / \mathrm{p}_{\mathrm{o}}\right) \mathrm{R} \mathrm{T} / \mathrm{V}$ 
Onde: $\mathrm{P}=$ pressão capilar; $\mathrm{s}=$ tensão superficial da água; $\mathrm{r}=$ tamanho do poro; $\mathrm{p} / \mathrm{p}_{\mathrm{o}}=$ umidade relativa; $\mathrm{R}=$ constante dos gases; $\mathrm{T}=$ temperatura absoluta $\mathrm{e} \mathrm{V}=$ volume molar da água.

De acordo com Biarez et al. (1987), as pressões capilares se traduzem pela diferença de pressão intersticial entre o ar e a água contidos nos poros, e conduz a formação de um menisco. Em materiais que não apresentam tensões externas, imaginase que a pressão capilar torna-se igual a sucção. Desta forma, determinando a tensão de sucção, pode-se obter informações sobre as tensões decorrentes da compressão de ar nos poros.

\subsection{COMPORTAMENTO DOS SOLOS NÃO SATURADOS}

\subsubsection{Considerações Gerais}

Os solos não saturados são caracterizados pela ocorrência de ar em seus vazios, em quantidade que varia de acordo com o grau de saturação e seu comportamento apresenta-se influenciado pelas fases constituintes do solo (sólida, líquida e gasosa) presentes e suas interações (Vilar, 2000).

Segundo Jucá (1993), os fenômenos mais característicos do comportamento de solos não saturados, são os relacionados com suas deformações volumétricas, quando é modificado seu grau de saturação.

Para analisar o comportamento destes solos, o conhecimento das pressões intersticiais na fase líquida apresenta especial interesse. Apesar da importância fundamental da superfície específica na predominância das forças de superfície em relação às de massa, torna-se claro que, para explicar a resposta de um solo não saturado, é necessário contar com outros fatores, cuja influência é determinante no seu comportamento, tais com, forma das partículas, estrutura, características mineralógicas da fase sólida e constituição da fase líquida (Presa et al., 1988).

Não é possível explicar o comportamento do solo com base em um único fator ou na combinação de fatores simples, porque este é função das combinações e interrelações de diversos fatores. 


\subsubsection{Fases Constituintes do Solo}

Em um solo distinguem-se três fases constituintes: a sólida, a líquida e a gasosa. As fases líquida e gasosa do solo compreendem o volume de vazios, enquanto a fase sólida constitui o volume de sólidos (Badillo e Rodríguez, 1988).

De acordo com Presa (1984), os solos são caracterizados por possuírem não mais que três fases: sólida, líquida e gasosa podendo não coexistir as duas últimas. Disto podem resultar três situações possíveis: solos secos, solos saturados e solos não saturados ou parcialmente saturados.

Segundo Yoshimi e Osterberg (1963), estas três fases podem ser representadas pelo esquema a seguir:

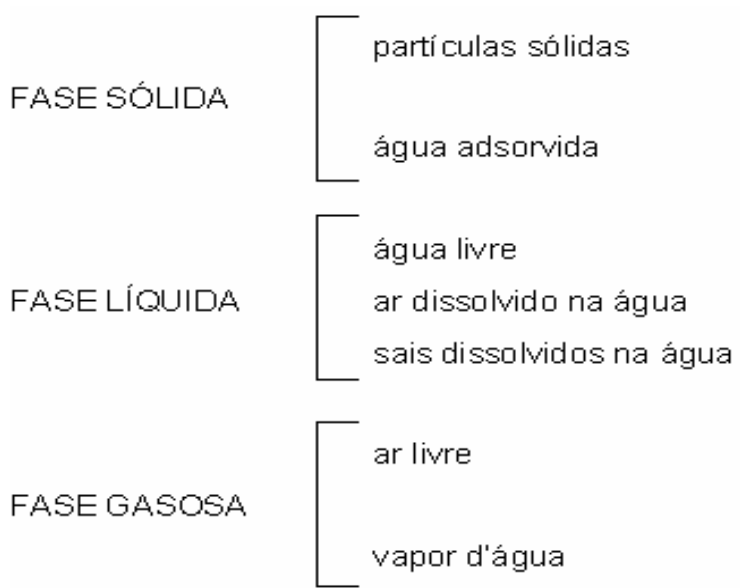

Fredlund e Morgenstern (1977), propuseram uma quarta fase de interesse, que seria a interface ar livre - água livre, composta por uma película de propriedades diferentes daquelas da água e do ar que a compõe.

Segundo Jucá (1993), como as relações peso-volume consideram o solo um sistema trifásico, essa membrana contrátil não será considerada como fase, sendo seu volume desprezado e seu peso incorporado ao peso da água.

A seguir serão descritos alguns aspectos básicos sobre as três fases constituintes do solo, por serem de extrema importância para o entendimento do comportamento dos solos não saturados. 


\subsubsection{Fase sólida}

Segundo Mitchell (1976), as partículas que constituem a parte sólida são compostas por minerais e matéria orgânica e apresentam-se sob diversas formas, variando de grãos esféricos até angulosos, alongados e achatados. Em relação ao tamanho, podem variar desde matacões até grãos visíveis apenas com o auxílio de microscópio eletrônico. Estes grãos podem variar em textura, composição mineralógica e configuração cristalográfica. Quanto a estes aspectos, é de extrema importância ser considerado a superfície específica das partículas, as quais estão intimamente associadas ao tipo e predomínio das forças que atuam nas partículas do solo.

\subsubsection{Fase líquida}

Esta fase é composta fundamentalmente por água e ar dissolvidos nela. A água pode ser classificada em três tipos (Jucá, 1993):

1) Água adsorvida: que é aquela que adere à superfície da partícula, devido à existência de cargas elétricas negativas nessa superfície ou fazendo parte da dupla camada difusa e que não pode ser separada por forças hidrodinâmicas.

2) Água capilar: ocorre nos solo devido às forças de capilaridade desenvolvidas no contato água - partícula e podem mover-se pela ação destas. As forças de capilaridade são mais fortes quando o solo encontra-se não saturado e são mais intensas, quanto mais argiloso for este solo.

3) Água gravitacional: é aquela que pode ser perdida pelo solo quando ocorrer drenagem livre por gravidade.

Segundo Jucá (1993), do ponto de vista hidrodinâmico, a água gravitacional e capilar formam uma só unidade e podem ser denominadas de água livre.

Quanto aos sais dissolvidos na água, sua concentração pode afetar o desenvolvimento da dupla camada difusa. É conhecida a influência que a existência e tipo destes sais podem ter no comportamento do solo, podendo provocar notáveis variações volumétricas ou de resistência (Jucá, 1993). 


\subsubsection{Fase gasosa}

A fase gasosa é constituída por ar livre e vapor d'água, e está presente no espaço poroso não ocupado pela água, quando o solo encontra-se seco ou não saturado.

Próximo à superfície, a composição química da fase gasosa do solo assemelha-se à da atmosfera, apresentando diferenças quanto aos teores de oxigênio e gás carbônico, devido ao oxigênio do solo ser consumido por microorganismos e pelo sistema radicular das plantas superiores, os quais promovem uma redução na taxa de oxigênio quando comparada à atmosfera (São Mateus, 1994).

Uma característica importante do ar livre deve-se a sua compressibilidade (Jucá, 1993). Como é sabido, o comportamento dos gases é regido pelas relações entre seu volume, pressão e temperatura (Barrow, 1961). Assim, para as faixas de pressão e temperaturas usuais, o ar pode ser considerado como um gás perfeito, atendendo a Lei de Boyle - Gay - Lussac.

A presença de vapor d'água na fase gasosa do solo está associada ao processo de evaporação da água contida nos poros. A evaporação ocorre quando a pressão de vapor de ar estiver abaixo da pressão máxima de vapor, para uma dada temperatura.

A pressão de vapor depende grandemente da temperatura, mas também é afetada pela pressão parcial do ar com o qual o vapor se mistura e a forma da superfície de contato entre as fases líquida e gasosa (Hilf, 1956).

\subsubsection{Potencial de Água no Solo}

\subsubsection{Considerações Gerais}

O estado da água num solo pode ser expresso em termos de energia livre relativa a água pura livre (Aitchison, Russam e Richards, 1965). A energia livre pode ser expressa em termos de potenciais $(\phi)$, cargas hidráulicas (h) ou pressões.

Segundo Aitchison (1965), a sistematização dos conceitos de energia advindos da termodinâmica e utilizados constantemente na Física dos Solos e sua extensão à Mecânica dos Solos, iniciou-se em 1965, no Simpósio "Engineering Concepts of Moisture Equilibra and Moisture Changes in Soils".

A primeira definição de potencial energético de um fluido no solo foi dada por Buckingham (1907) apud Machado (1998), que realizou estudos sobre o movimento da 
água no solo, e introduziu o conceito de potencial capilar como sendo a energia gasta ou necessária para deslocar uma unidade de massa de água, em sentido contrário ao das forças capilares, de um certo local até o nível da água livre, sujeita à pressão atmosférica.

Este conceito posteriormente evoluiu, passando a considerar as parcelas de energia decorrentes da temperatura, velocidade de fluxo da água, fenômenos osmóticos e de adsorção, posição da partícula de água e pressão exercida sobre ela (Machado, 1998).

Quando um trabalho é realizado sobre a água, sob condições específicas, sua energia potencial é alterada em uma quantidade igual ao trabalho realizado. Esta variação da energia potencial da água em relação a um estado padrão de referência arbitrado, é definido segundo Marshall e Holmes (1981) como Potencial Total da Água no Solo.

O Potencial Total de Água no Solo $(\phi)$, representa "o trabalho útil que deve ser realizado em uma quantidade infinitesimal de água pura, para transportá-la, em condições reversível e isotérmicamente, desde um reservatório sob condições padronizadas (isto é, água pura, em uma determinada cota e sujeita à pressão atmosférica) - Ponto A -até a água no solo, no ponto considerado - Ponto B - e sujeita à pressão u ${ }_{\mathrm{B}}$ "(Iwata et al., 1988; Brady, 1989).

A Figura 10 ilustra a definição de Potencial Total de Água no Solo.

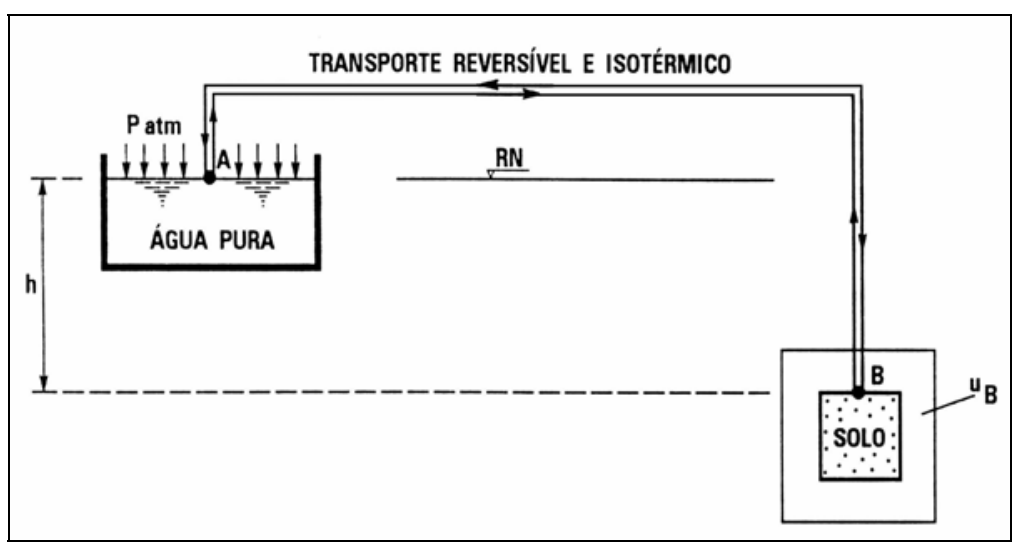

FIGURA 10. Esquema ilustrativo da definição do Potencial Total de Água no Solo (Vilar, 2000). 
O estado de energia potencial da água no solo é representado pelo potencial total que é composto por diversas parcelas, das quais na prática, as mais importantes são as componentes gravitacional, matricial, osmótica e pneumática (Vilar, 1997).

De acordo com Machado (1998), para que se defina o potencial de água no solo, deve-se antecipadamente se estabelecer um estado de referência padrão, a partir do qual as medidas da água no solo possam ser retiradas sem ambigüidades. Levando em conta a componente de água no solo, além da componente água, define-se o estado de referência padrão como sendo uma solução livre da influência da matriz do solo, pura (sem a presença de solutos), num dado referencial de posição, à uma dada temperatura e submetida à pressão atmosférica padrão.

Genericamente, a equação do potencial de água no solo pode ser escrita da seguinte forma (Baver e Gardner, 1972):

$\phi \mathrm{t}=\phi \mathrm{temp}+\phi \mathrm{p}+\phi \mathrm{m}+\phi \mathrm{os}+\phi \mathrm{z}$

Onde: $\phi t=$ potencial total da água no solo em relação a um potencial padrão; $\phi$ temp $=$ potencial térmico; $\phi \mathrm{p}=$ potencial pneumático; $\phi \mathrm{m}=$ potencial matricial, ocorre quando o solo está na condição não saturada; $\phi o s=$ potencial osmótico e $\phi z=$ potencial gravitacional ou de posição, devido ao campo gravitacional terrestre.

Admitindo-se que os processos que envolvem o potencial total da água sejam isotérmicos, a equação 2 pode ser redefinida como:

$\phi \mathrm{t}=\phi \mathrm{z}+\phi \mathrm{p}+\phi \mathrm{m}+\phi \mathrm{os}$

Assim, as parcelas de energia que contribuem efetivamente para o potencial de água no solo são as de posição ou gravitacional, pneumática, matricial (capilaridade e adsorção) e osmótica.

Convencionou-se que o sinal do potencial total da água de um solo é positivo ou negativo, conforme o solo tenda a expulsar ou absorver água, respectivamente, ao colocá-lo em contato com a água livre pura, submetida à pressão atmosférica e com a mesma temperatura do solo (Presa et al., 1988). 


\subsubsection{Potencial Gravitacional $(\phi z)$}

Existe independente da condição do solo, estando relacionado apenas com o campo gravitacional terrestre, não exercendo nenhuma influência sobre a sucção. Este potencial equivale à energia potencial do campo gravitacional e " $z$ " é medido a partir de um referencial de posição arbitrário.

\subsubsection{Potencial Pneumático ( $\phi p)$}

O Potencial pneumático é igual ao trabalho resultante da pressão manométrica (pressão absoluta menos pressão atmosférica) que eventualmente exista no ar contido nos vazios do solo (Machado, 1998).

Este potencial é originado por pressões externas de gás diferentes da pressão atmosférica e é especialmente importante quando se consideram os ensaios de placa de pressão ou a técnica de translação de eixos (Vilar, 1997). É gerado pela pressão que a coluna do fluido exerce sobre o ponto considerado na massa de solo (São Mateus, 1994).

A componente de pressão pode ser calculada pela seguinte expressão:

$\phi p=\gamma . h$

Onde: $\phi p=$ potencial de pressão $\left(\mathrm{kN} / \mathrm{m}^{2}\right) ; \gamma=$ peso específico do fluido presente no solo saturado $\left(\mathrm{kN} / \mathrm{m}^{2}\right)$ e $\mathrm{h}=$ altura da coluna do fluido.

Caso o valor de "h" seja negativo, a pressão também será, o que é um indicativo de que o solo encontra-se não saturado e assim, o potencial matricial ( $\phi \mathrm{m})$ é que passará a atuar no lugar do potencial de pressão $(\phi p)$.

\subsubsection{Potencial Osmótico ( $\phi$ os)}

O Potencial Osmótico ocorre em função da diferença de composição entre a água do solo (presença de sais minerais e substâncias orgânicas) e a água pura. Trata-se de 
uma componente de difícil medição, portanto, é determinado através de instrumentos especiais. Este potencial é medido em unidade de pressão (energia/volume).

Segundo Fonseca (1991), o potencial osmótico é de grande importância em solos de textura fina, quando o tipo e concentração dos solutos presentes forem significativos, o que ocorre para teores de umidade baixos e em regiões onde o acúmulo de sais é intenso.

De acordo com Reichardt (1985), para a maioria dos solos, o potencial osmótico pode ser desprezado, principalmente em casos onde a umidade for elevada.

\subsubsection{Potencial Matricial ( $\phi \mathrm{m})$}

De acordo com Wolle e Carvalho (1988), a análise clássica identifica um solo como um sistema trifásico composto por uma fase sólida que corresponde ao esqueleto dos grãos e por duas fases fluidas, uma gasosa (ar e vapor d’água) e uma líquida (água), ambas associadas aos poros não saturados. Devido às interações que ocorrem entre a água e o ar (efeito de capilaridade) e entre a água e as partículas sólidas (forças superficiais de origem eletroquímica), a água é atraída pelo esqueleto sólido (matriz do solo) por um conjunto de forças que pode ser associado a um potencial hidráulico, normalmente chamado de "potencial matricial". Definindo-se o nível de referência como sendo o potencial da água livre sob pressão atmosférica, o potencial matricial assume valores negativos.

Segundo Hillel (1971), o potencial matricial da água do solo é um potencial de pressão, que ocorre devido o efeito combinado da ação das forças capilares e de adsorção, que surgem da interação entre a água e as partículas minerais ou a matriz que compõe o solo.

Em solos não saturados o comportamento resistente e as variações volumétricas associadas a expansibilidade do solo dependem, em larga escala, dos fenômenos de capilaridade e de adsorção responsáveis pela origem do potencial matricial (Vilar, 1997).

Para descrever a energia da retenção de água no solo, além do potencial matricial, são utilizados outros termos como, "pressão de sucção" e "pressão neutra negativa", que indicam respectivamente, a tendência do solo não saturado em succionar a água livre com a qual está em contato, e o fato de que, encontrando-se o ar a pressão atmosférica, a 
pressão da água será negativa. Assim, a pressão de sucção equivale a pressão neutra $\left(\mathrm{p}_{\mathrm{suc}}=-\mathrm{u}\right)$ (Wolle e Carvalho, 1988).

A pressão de sucção pode ser expressa em unidades de energia, pressão ou de altura de coluna d'água.

O Potencial matricial resulta da interação sólido-líquido-gás, gerando o surgimento de uma pressão negativa ou sucção, quando o solo encontra-se na condição não saturada. Quanto menor o teor de umidade do solo, maior a pressão negativa, sendo que $\phi \mathrm{m}$ apresenta um resultado diferente para cada teor de umidade.

Anteriormente, a componente matricial era denominada "potencial capilar", que não constituía um termo abrangente, já que este potencial envolve tanto os mecanismos de capilaridade quanto os de adsorção, que estão intimamente ligados (São Mateus, 1994).

Fredlund et al. (1978), definem que o potencial matricial ou pressão de sucção constitui uma das componentes do potencial hidráulico nos solos não saturados e numa das variáveis de tensão necessária para definir o estado de tensões nestes solos.

Todas as parcelas do potencial de água no solo são expressas na forma de energia por unidade de massa ou volume, mas podem ser substituídas pelos seus respectivos valores de pressão correspondentes a cada parcela.

Quando os potenciais gravitacional e pneumático puderem ser desprezados, a sucção total corresponde ao potencial total negativo de água no solo, que pode ser separada em suas duas componentes, sucção osmótica e matricial, que correspondem, respectivamente, ao potencial osmótico e ao potencial matricial.

\subsubsection{Sucção Total do Solo (S)}

A interação solo - água também pode ser quantificada a partir da avidez que um solo não saturado têm pela água. Quando o solo é colocado em contato com um reservatório de água pura livre, este absorve água, devido ao fato de exercer uma pressão de sucção sobre a água. Caso uma pressão de sucção seja aplicada sobre o reservatório, impedindo que o solo sorva água (não ocorra fluxo), têm-se uma pressão na água livre equivalente à pressão de sucção na água do solo. Essa pressão ou sucção representa outra forma do estado de energia da água em um solo não saturado e é governada por duas componentes denominadas matricial e osmótica (Vilar, 2000). 
A sucção total da água no solo corresponde ao trabalho total das forças de capilaridade, adsorção e osmose, e pode ser definida como, a pressão negativa (em relação à pressão do ar) a que se deve submeter a água pura (sem a presença de solutos), para que, ao colocá-la em contato com o solo através de uma membrana semipermeável, exista equilíbrio. No caso de não ser utilizada água pura e sim água de composição idêntica a do solo, o termo referente a sucção osmótica se anularia e assim, teria-se apenas a sucção matricial (Presa et al., 1988).

Segundo Vilar (2000), a sucção total do solo é definida como a pressão manométrica, em relação à pressão externa de gás sobre a água do solo, que deve ser aplicada a um reservatório de água pura (a mesma cota e temperatura) de sorte a que se mantenha o equilíbrio, através de uma membrana semipermeável (permite o fluxo de água, mas não de solutos), entre a água do reservatório e a água do solo. A Figura 11 esquematiza essa definição.

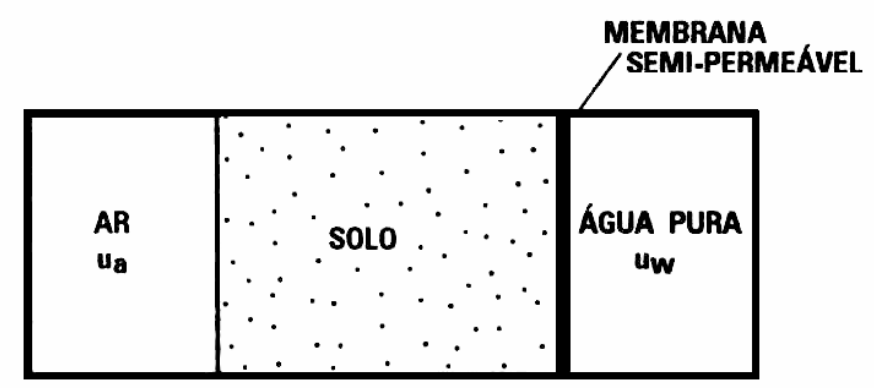

FIGURA 11. Esquema ilustrativo da definição de sucção. Sucção: corresponde a $u_{a}-u_{w}$ de sorte a não haver fluxo através da membrana semipermeável. Comumente $u_{a}=p_{a t m}$ (Vilar, 2000).

De acordo com Richards (1928), a existência da sucção em solos não saturados deve-se aos efeitos combinados de capilaridade (predominante em solos arenosos), de adsorção (predominante em solos argilosos) e de osmose (que têm a mesma importância relativa tanto no caso de solos saturados quanto não saturados) e que deve-se à presença de íons dissolvidos na água.

Segundo Vilar (2000), um aspecto característico dos solos não saturados refere-se a pressão da água intersticial que sempre encontra-se sujeita a pressões inferiores à atmosférica e muitas vezes abaixo de $-100 \mathrm{kPa}$, que representa a pressão de vaporização da água à temperatura ambiente. Esta pressão negativa deve-se aos 
fenômenos de capilaridade e de adsorção, responsáveis pelo aparecimento da sucção matricial e fenômenos osmóticos, devido a presença de solutos na água do solo, responsáveis pela sucção osmótica.

A sucção total de água no solo é dada pela equação abaixo:

$\mathrm{S}=\mathrm{S}_{\mathrm{m}}+\mathrm{S}_{\mathrm{os}}=\mathrm{u}_{\mathrm{a}}-\mathrm{u}_{\mathrm{w}}$

Onde: $\mathrm{S}=$ sucção total de água no solo; $\mathrm{S}_{\mathrm{m}}=$ sucção matricial; $\mathrm{S}_{\mathrm{os}}=$ sucção osmótica; $\mathrm{u}_{\mathrm{a}}=$ pressão do ar e $\mathrm{u}_{\mathrm{w}}=$ pressão da água.

\subsubsection{Sucção Matricial}

A sucção matricial $\left(\mathrm{S}_{\mathrm{m}}\right)$ é igual à sucção total quando a água do solo é idêntica à água padrão (água pura ou solução com a mesma composição do solo), ou seja, $\mathrm{S}_{\mathrm{os}}$ igual a zero, restando apenas o efeito da matriz do solo (capilaridade e adsorção).

A sucção matricial pode ser definida como a pressão negativa (em relação à pressão do ar) a que se deve submeter uma solução de composição idêntica à da água do solo para que exista equilíbrio ao colocar ambas em contato através de uma membrana permeável (Presa et al., 1988).

A sucção matricial corresponde ao potencial matricial em termos de pressão e pode ser definida como a diferença entre as pressões de ar $\left(\mathrm{u}_{\mathrm{a}}\right)$ e da água $\left(\mathrm{u}_{\mathrm{w}}\right)$, presentes nos poros do solo. Supondo que os vazios do solo estejam em contato com a pressão atmosférica (considerada igual a zero, para efeito de referência), $\left(u_{\mathrm{a}}\right)$ terá o mesmo valor da pressão atmosférica. Assim, a sucção matricial será representada pela pressão negativa da água nos poros.

A medida da sucção matricial de um solo esbarra numa série de dificuldades experimentais e comumente, deve-se recorrer a diferentes técnicas de ensaio, com o intuito de conhecer-se o potencial dentro de uma faixa ampla o suficiente para a utilização na prática. 


\subsubsection{Sucção Osmótica}

A sucção osmótica $\left(\mathrm{S}_{\mathrm{os}}\right)$ é igual à sucção total quando o solo se encontra saturado, ou seja, quando a componente matricial não ocorre, restando apenas o efeito da concentração de solutos.

A sucção osmótica pode ser definida como a pressão negativa (em relação à pressão do ar) a que se deve submeter a água pura para que haja equilíbrio ao colocá-la em contato com a água do solo, através de uma membrana semi-permeável, que permita somente a passagem das moléculas de água (Presa et al., 1988).

A sucção osmótica é derivada das forças osmóticas associadas à composição da água do solo, que por sua vez é influenciada pela capacidade das partículas do solo de reter os íons trocáveis, que alteram a composição da água. $\mathrm{O}$ valor da sucção osmótica irá depender da composição do líquido externo ao solo. Assim, o valor máximo será atingido quando a água que entra em contato com o solo for pura e nula, se a água externa possuir a mesma composição química da água intersticial. Quando uma partícula de argila é colocada num meio aquoso, as moléculas superficiais da partícula se ionizam na presença dos cátions de hidrogênio. Por outro lado, os cátions existentes em sua superfície tendem a se hidratar, deixando a superfície do argilomineral, onde existe uma elevada concentração destes. Esta tendência a difundir-se na água para igualar a sua concentração é contraposta pelo estabelecimento de forças atrativas resultantes das cargas negativas superficiais. Como estas forças diminuem com o aumento da distância da superfície do argilomineral, a concentração de cátions tenderá a ser menor com o aumento desta distância. As diferentes concentrações de cátions e íons em torno do argilomineral e na região de água livre geram o aparecimento de forças osmóticas, resultando na componente osmótica da sucção no solo (Machado, 1998).

Deve-se lembrar que as sucções matricial e osmótica são grandezas positivas, enquanto os correspondentes potenciais são negativos. Isto pode ser observado na Figura 12, considerando que esteja atuando a pressão atmosférica. $\mathrm{O}$ reservatório de água pura livre constitui-se num referencial para a medida de energia, ao qual é atribuído o valor zero. Como a água flui espontaneamente do reservatório para o solo, resulta que o potencial no solo deve ser inferior ao padrão, por conseguinte, negativo.

A Figura 12 ilustra os conceitos de sucção total, matricial e osmótica. 


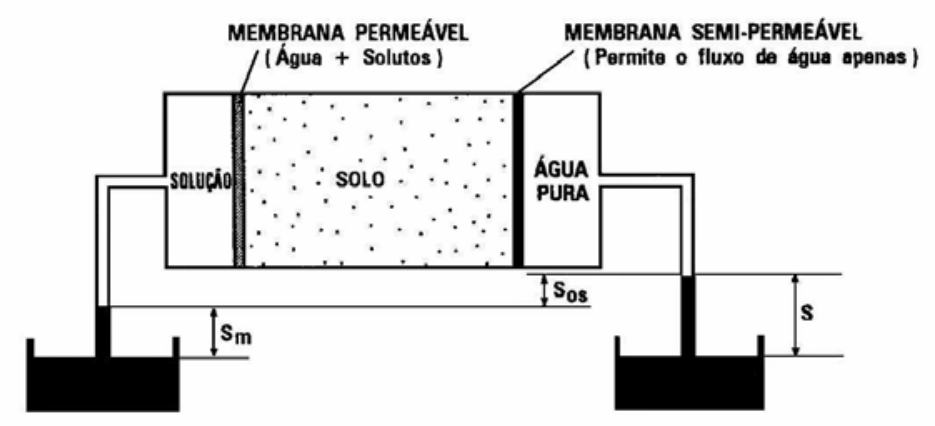

FIGURA 12. Esquema ilustrativo da definição de sucção matricial, osmótica e total (Vilar, 2000).

\subsubsection{Curva de Retenção de Água no Solo}

Segundo Jucá (1993), as relações sucção - umidade (grau de saturação, umidade gravimétrica ou umidade volumétrica) desempenham um papel importante na caracterização de solos não saturados. A forma de representar graficamente esta relação denomina-se, Curva de Sucção ou Curva de Retenção de Água no Solo. A natureza desta relação está diretamente associada a composição granulométrica e estrutura do solo.

A curva de retenção de água no solo pode ser definida como a variação da sucção com a capacidade de retenção da água nos microporos e macroporos do solo (Fredlund, Xing e Huang, 1994).

Para a obtenção em laboratório da curva de retenção de água no solo, pode-se seguir dois processos: o de infiltração (umedecimento) ou de drenagem (secagem) da água contida no solo.

O processo de umedecimento do solo consiste em tomar uma amostra seca ao ar e umedecê-la gradualmente, provocando a redução da sucção matricial. Por outro lado, no processo de secagem, utiliza-se amostras na condição de saturação e aplica-se pressões sucessivas, de forma a expulsar a água do material. O principal objetivo na obtenção desse tipo de curvas, é a avaliação da sucção matricial em função da umidade do solo.

Geralmente a geometria e a distribuição dos poros, além da composição mineralógica da fração fina do solo, são fatores que determinam a forma e inclinação das curvas de retenção de água no solo (Jucá, 1993). 
As curvas de retenção são diferentes para solos argilosos, siltosos e arenosos. No caso do primeiro são necessários maiores teores de umidade para que ocorra a redução da sucção matricial, que é explicado pelo fato do solo argiloso possuir poros menores quando comparados ao solo arenoso, ocorrendo a formação de finíssimos capilares, os quais induzem o aparecimento de meniscos com curvaturas acentuadas, quando o solo entra em contato com a água. Assim, quanto mais acentuada a curvatura, maior será a diferença de pressão na interface líquido - ar e conseqüentemente, maior terá que ser a umidade para reduzi-la.

No caso do mecanismo de adsorção, que ocorre de forma mais intensa em solos de textura fina, quanto mais fino for o solo, maior será a sua superfície específica e, maiores serão as forças de adsorção que irão se desenvolver na superfície das partículas. Assim, torna-se necessário aumentar o teor de umidade para reduzir as forças de adsorção, que provocará a redução também da sucção matricial.

A Figura 13 mostra as curvas de retenção de água para diferentes solos, onde se observa que os solos argilosos apresentam maior capacidade de retenção de água para a mesma sucção e pressão de entrada de ar que para os solos arenosos. Além disso, pequenas variações de sucção respondem por praticamente toda a variação de umidade nos solos arenosos, enquanto nos argilosos há necessidade de amplas variações de sucção para apresentar modificações sensíveis de umidade (Vilar, 2000).

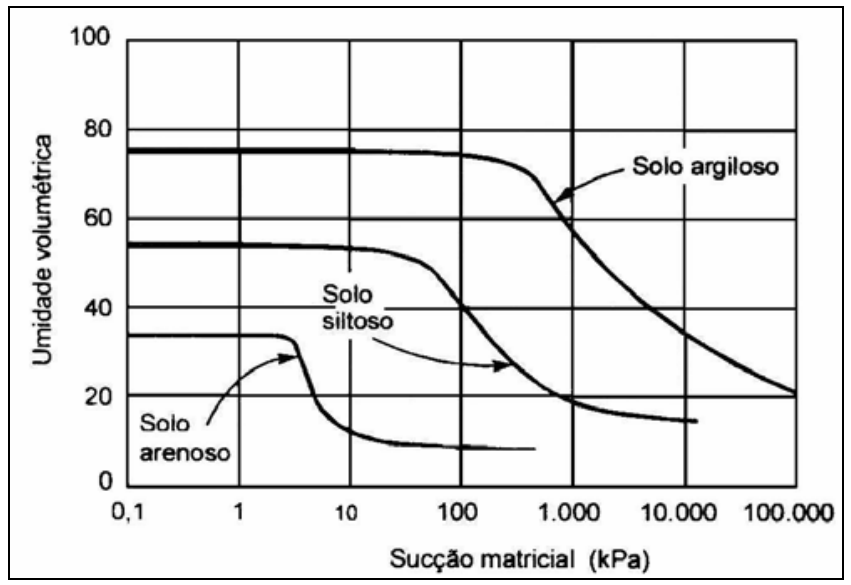

FIGURA 13. Posições relativas das curvas de retenção para diferentes solos (Vilar, 2000).

A Figura 14 ilustra os principais elementos da curva de retenção da água no solo, que são a umidade de saturação $\left(\theta_{\mathrm{s}}\right)$, a pressão de entrada de ar, que quando atingida, 
implica no início do esvaziamento do maior poro e onde para valores inferiores, o solo se mantêm saturado, embora com pressões na água negativas e a umidade residual $\left(\theta_{\mathbf{r}}\right)$, que representa um valor abaixo do qual, praticamente não se consegue mais extrair água do solo com o aumento da sucção.

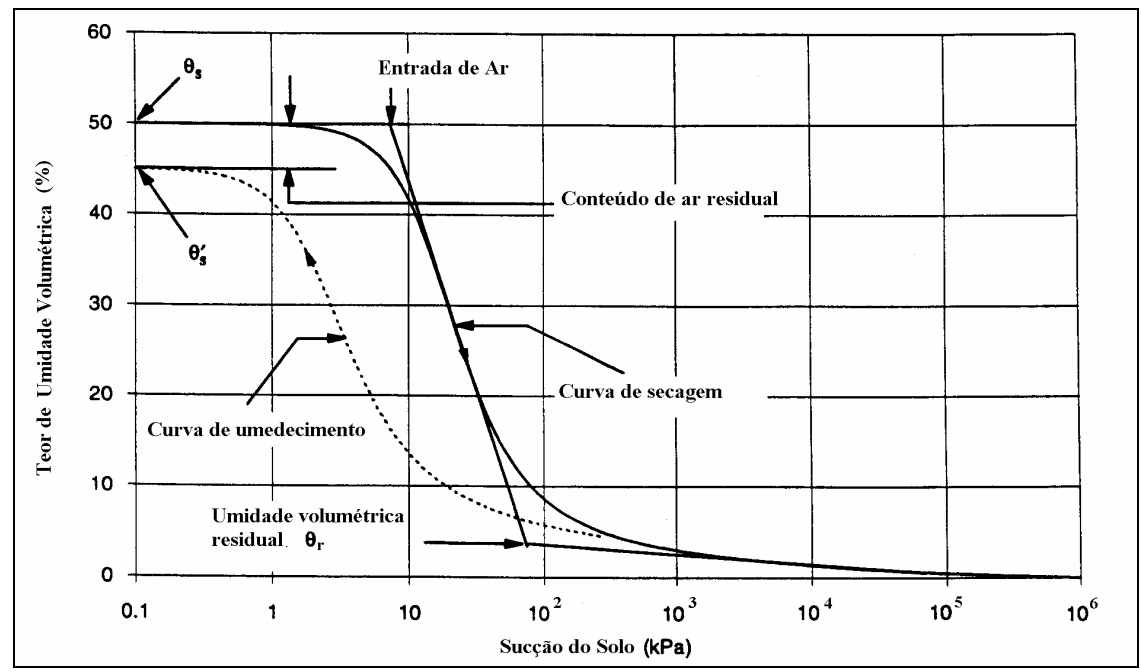

FIGURA 14. Caracterização da curva de retenção segundo Fredlund, Xing e Huang (1994).

Para representar a quantidade de água presente no solo, recorre-se à umidade em termos de massa $(w)$, ao grau de saturação $(\mathrm{Sr})$ ou a umidade volumétrica $(\theta)$. A umidade volumétrica $(\theta)$ é a relação entre volume de água e o volume total do solo, e pode ser expressa por:

$\theta=\mathrm{V}_{\mathrm{w}} / \mathrm{V}$

Esta expressão se relaciona com a umidade gravimétrica (w) através de:

$\mathrm{w}=\rho_{\mathrm{w}} \theta / \rho_{\mathrm{d}}$

Onde: $\rho_{\mathrm{d}}=$ massa específica seca do solo $\left(\mathrm{g} / \mathrm{cm}^{3}\right) ; \mathrm{w}=$ umidade gravimétrica $(\%)$ e $\rho_{\mathrm{w}}=$ massa específica da água $\left(1 \mathrm{~g} / \mathrm{cm}^{3}\right)$. 
A curva de retenção pode ser definida mediante relações empíricas, a partir dos dados de sucção e umidade volumétrica. Diversas relações empíricas são comumente usadas para estimar a curva de retenção de água. Algumas delas são apresentadas na Tabela 02.

TABELA 02. Relações empíricas para estimar a curva de retenção de água no solo

\begin{tabular}{|c|c|c|c|}
\hline Autores & Modelos & & Definição dos parâmetros \\
\hline $\begin{array}{l}\text { Farrel e Larson } \\
\text { (1972) }\end{array}$ & $\theta=\theta_{r}+\left(\theta_{s}-\theta_{r}\right)\left(1-\frac{1}{\alpha} \ln \left(\frac{\psi}{\psi_{\text {crit. }}}\right)\right.$ & (8) & $\begin{array}{l}\theta, \quad \theta_{\mathrm{s}}, \quad \theta_{\mathrm{r}}=\text { respectivamente } \\
\text { teores de umidade volumétrica, } \\
\text { saturada e residual; } \\
\psi=\text { sucção matricial; } \\
\psi_{\text {crit. }}=\text { sucção matricial que } \\
\text { corresponde à entrada de ar (air } \\
\text { entry) }(\mathrm{kPa}) ; \\
\alpha=\text { parâmetro de ajuste. }\end{array}$ \\
\hline $\begin{array}{l}\text { Simmons et al. } \\
\text { (1979) }\end{array}$ & $\theta=\phi+\frac{1}{\beta} \ln \left(\frac{\psi}{\alpha}+1\right)$ & (9) & $\begin{array}{l}\phi=\text { umidade de saturação; } \\
\beta \text { e } \alpha=\text { parâmetros de ajuste. }\end{array}$ \\
\hline $\begin{array}{l}\text { Libardi et al. } \\
\text { (1979) }\end{array}$ & $\theta=\theta_{s}+\frac{1}{\beta} \ln \left(\frac{\psi}{\alpha}+1\right)$ & $(10)$ & $\beta$ e $\alpha$ \\
\hline $\begin{array}{l}\text { Van Genuchten } \\
\text { (1980) }\end{array}$ & $\theta=\theta_{\mathrm{r}}+\frac{\left(\theta_{\mathrm{s}}-\theta_{\mathrm{r}}\right)}{\left(1+\left|\alpha_{\mathrm{v}} \psi\right|^{\mathrm{n}}\right)^{\mathrm{m}}}$ & (11) & $\begin{array}{l}\mathrm{m}=1-1 / \mathrm{n} ; \\
\mathrm{n}=\text { parâmetro de ajuste; } \\
\alpha_{\mathrm{v}}=\text { parâmetro de ajuste da } \\
\text { curva }(1 / \mathrm{kPa}) ; \\
\theta_{\mathrm{r}}=\text { teor de umidade } \\
\text { volumétrica residual }\left(\mathrm{cm}^{3} / \mathrm{cm}^{3}\right) .\end{array}$ \\
\hline Driessen (1986) & $\theta=\theta_{s} \psi^{-\gamma \ln (\psi)}$ & (12) & $\gamma=$ parâmetro de ajuste. \\
\hline $\begin{array}{l}\text { Fredlund et al. } \\
\text { (1994) }\end{array}$ & $\theta=\theta_{\mathrm{s}}\left[1-\frac{\ln \left(1+\frac{\psi}{\psi_{\mathrm{r}}}\right)}{\ln \left(1+\frac{10^{6}}{\psi_{\mathrm{r}}}\right)}\right] \frac{1}{\ln \left(\mathrm{e}+\left(\frac{\psi}{\mathrm{a}}\right)^{\mathrm{n}}\right.}$ & (13) & $\begin{array}{l}\psi_{\mathrm{r}}=\text { suç̧ão que corresponde à } \\
\text { umidade volumétrica residual } \\
(\mathrm{kPa}) ; \\
\theta=\text { teor de umidade } \\
\text { volumétrica }\left(\mathrm{cm}^{3} / \mathrm{cm}^{3}\right) ; \\
\theta_{\mathrm{s}}=\text { teor } \mathrm{de} \text { umidade } \\
\text { volumétrica de saturação } \\
\left(\mathrm{cm}^{3} / \mathrm{cm}^{3}\right) ; \\
\mathrm{e}=2,71828 ; \\
\mathrm{a}=\text { valor aproximado da sucção } \\
\text { de entrada de ar }(\mathrm{kPa}) ; \\
\mathrm{n}, \mathrm{m}=\text { parâmetros de ajuste; } \\
10^{6}=\text { valor limite de sucção para } \\
\text { qualquer tipo de solo (kPa). }\end{array}$ \\
\hline
\end{tabular}




\subsubsection{Histerese}

Este fenômeno pode ser observado através das curvas de retenção de água no solo, que mostram que a trajetória das curvas obtidas pelos processos de umedecimento e secagem são diferentes para um mesmo solo. A diferença das trajetórias por ambos os processos podem ser observadas na Figura 14.

Como mostra a Figura 14, para que sejam alcançadas as várias sucções durante o processo de drenagem, o solo apresenta teores de umidade mais elevados para a mesma sucção, do que na curva de umedecimento.

Segundo Davidson et al. (1966); Hillel (1980), esse comportamento da curva de retenção afeta diretamente as condições de fluxo no solo não saturado. A natureza deste comportamento é atribuída a diferentes causas que serão mostradas a seguir:

1) $\mathrm{O}$ efeito de ângulo de contato do menisco de água é maior quando ocorre umedecimento e menor na fase de secagem.

2) Devido às irregularidades geométricas dos poros interconectados que atingem o equilíbrio em posições diferentes para ambos os procedimentos, com diferentes quantidades de água.

3) Bolhas de ar capturadas nos vazios do solo no processo de umedecimento.

4) Alterações da estrutura do solo produzidas pela expansão ou contração nos solos argilosos, nos procedimentos de umedecimento e secagem respectivamente.

Recomenda-se que seja realizada a curva de umedecimento para infiltração e a curva de secagem quando se tratar de evaporação, para minimizar os problemas que ocorrem devido à este fenômeno, que apresentará maiores dificuldades na resolução quando forem tratados simultaneamente (São Mateus, 1994).

\subsubsection{Estado de Tensões}

\subsubsection{Considerações Gerais}

As deformações resultantes das variações volumétricas do solo são influenciadas por diversos fatores que podem ser considerados em três grupos: características do solo, que influenciam na natureza das forças internas interpartículas; os fatores do meio 
ambiente, que influenciam nas mudanças que podem ocorrer no sistema de forças internas interpartículas e o estado de tensões. Dos fatores mencionados, os efeitos produzidos pelas mudanças de tensão tem sido os mais estudados.

Todos os solos existentes na natureza se deformam, quando submetidos a solicitações externas ou internas, porém a estrutura multifásica dos solos saturados ou não saturados confere-lhes, um comportamento próprio tensão - deformação. Sendo assim, os fenômenos deformacionais são tratados na mecânica dos solos com a relação índice de vazios versus tensão efetiva nos solos saturados utilizando ensaios edométricos simples e através das variáveis de estados de tensão para solos não saturados valendo-se de ensaios edométricos com sucção controlada ou triaxiais.

Tanto em solos saturados, como em solos não saturados, as propriedades de importância na engenharia como a resistência, deformação e permeabilidade estão associadas às tensões atuantes no esqueleto sólido ou estrutura do solo. A estrutura do solo representa o arranjo e as forças atuantes entre as partículas, bem como, a composição mineral, as propriedades elétricas da superfície das partículas, características iônicas da água do solo e a complexa adsorção.

$\mathrm{Na}$ sua constituição, a estrutura do solo é composta pela interação de uma diversidade de forças intergranulares. Nos solos de granulação fina, efeitos como a interação de forças de superfície tornam-se predominantes, essencialmente se a superfície específica aumenta quando o tamanho das partículas diminui.

As forças de superfície nos solos finos são de natureza física, elétrica e química e suas magnitudes são função de numerosos fatores manifestando-se numa diversidade de forças atrativas (atração eletrostática, atração eletromagnética de Van der Waals, interação química por enlace de valência primária e cimentação) e repulsivas (forças eletrostáticas, hidratação de íons e de superfície) Mitchell (1993).

\subsubsection{Solos saturados e Solos não saturados}

O princípio de tensões efetivas de Terzaghi caracteriza as condições de tensão em que se encontram submetidos os solos saturados. Segundo Jennings e Burland (1962); Bishop e Blight (1963), entre outros, as tensões efetivas são responsáveis pelos efeitos mecânicos num determinado solo e são definidas pelas tensões total e intersticial. Os efeitos mecânicos são associados às mudanças de volume e resistência ao cisalhamento 
de solos saturados ou secos. O equacionamento deste princípio é representado pela seguinte expressão:

$\sigma^{\prime}=\sigma-u$

Onde: $\mathrm{u}=$ pressão neutra ou pressão no fluído intersticial; $\sigma=$ tensão total ou aplicada proveniente da força ou sistema de forças externas aplicadas e $\sigma^{\prime}=$ tensão efetiva decorrente das forças intergranulares.

Observou-se que para os solos saturados uma variável de estado tensional (tensão efetiva de Terzaghi) comanda as variações de volume e a parcela de resistência devido ao atrito.

O sucesso do princípio das tensões efetivas de Terzaghi, levou diversos pesquisadores a tentar estendê-lo aos solos não saturados, modificando a expressão proposta. Bishop (1959); Croney et al. (1958); Lambe (1960); Aitchison (1961); Richards (1966), entre outros, tentaram retratar a tensão efetiva a partir de um equilíbrio de forças (atuando no contato interpartículas). Nestas equações a contribuição da sucção, geralmente era afetada por um fator empírico com a finalidade de ser incluída dentro do estado de tensão (Nelson e Miller, 1992).

Foram várias as propostas realizadas, podendo ser observadas na Tabela 03 (Fredlund e Morgenstern, 1977).

TABELA 03. Equações para tensões efetivas em solos não saturados (Fredlund e Morgenstern, 1977)

\begin{tabular}{|l|l|}
\hline Equação & Referência \\
\hline$\sigma^{\prime}=\sigma-u_{\mathrm{a}}+X\left(\mathrm{u}_{\mathrm{a}}-\mathrm{u}_{\mathrm{w}}\right)$ & Bishop (1959) \\
\hline$\sigma^{\prime}=\sigma+\mathrm{p} "$ & Donald (1956) \\
\hline$\sigma^{\prime}=\sigma-\beta^{\prime} \cdot \mathrm{u}_{\mathrm{w}}$ & Croney, Coleman e Black (1958) \\
\hline$\sigma^{\prime}=\sigma \mathrm{a}_{\mathrm{m}}+\mathrm{u}_{\mathrm{a}} \cdot \mathrm{a}_{\mathrm{a}}+\mathrm{u}_{\mathrm{w}}+\mathrm{a}_{\mathrm{w}}+\mathrm{R}-\mathrm{A}$ & Lambe (1960) \\
\hline$\sigma^{\prime}=\sigma+\Phi \cdot \mathrm{p}^{\prime}$ & Aitchison (1961) \\
\hline$\sigma^{\prime}=\sigma+\beta \mathrm{p} "$ & Jennings (1961) \\
\hline$\sigma^{\prime}=\sigma-\mathrm{u}_{\mathrm{a}}+X_{\mathrm{m}}\left(\mathrm{h}_{\mathrm{m}}+\mathrm{u}_{\mathrm{a}}\right)+X_{\mathrm{s}}\left(\mathrm{h}_{\mathrm{s}}+\mathrm{u}_{\mathrm{a}}\right)$ & Richards (1966) \\
\hline$\sigma^{\prime}=\sigma-\mathrm{u}_{\mathrm{a}}+X_{\mathrm{m}} \cdot \mathrm{p}_{\mathrm{m}}+X_{\mathrm{s}} \cdot \mathrm{p}^{\prime}{ }_{\mathrm{s}}$ & Aitchison e Martin (1973) \\
\hline
\end{tabular}


Onde: $X$ : parâmetro relacionado com o grau de saturação; $\mathrm{u}_{\mathrm{a}}$, $\mathrm{u}_{\mathrm{w}}$ : pressão do ar e água respectivamente; $p$ ": pressão da água sob a atmosférica; $\beta^{\prime}$ : fator de união; $a_{a}$ : fração da área total que corresponde ao contato ar-ar; R: força de repulsão elétrica; A: força de atração elétrica; $\Phi$ :parâmetro entre 0 e $1 ; \beta$ : fator estatístico para medir área de contato; $X_{\mathrm{m}}, X_{\mathrm{s}}$ : parâmetro de tensão efetiva para sucção matricial e de soluto respectivamente; $h_{m}, h_{s}$ : sucção matricial e de soluto respectivamente e p" ${ }_{m}, p^{\prime \prime}$ : sucção matricial e de soluto respectivamente.

Entre essas equações destaca-se a expressão formulada por Bishop (1959), que pode representar uma síntese destas expressões e determina que a tensão efetiva num solo não saturado pode ser expressa como:

$\sigma^{\prime}=\left(\sigma-u_{a}\right)+\chi\left(u_{a}-u_{w}\right)$

Onde: $\sigma$ '= tensão efetiva do solo; $\sigma=$ tensão total; $u_{\mathrm{a}}=$ pressão de ar nos vazios do solo; $\chi=$ parâmetro que reflete a influência da sucção na tensão efetiva dos solos; $\mathrm{u}_{\mathrm{w}}=$ pressão de água nos vazios do solo.

Nessa formulação o parâmetro $X$ varia entre 0 para solos secos e 1 para solos saturados, e os valores intermediários dependem da trajetória de tensões dos ciclos de umedecimento e secagem e principalmente do grau de saturação (Blight, 1967).

Esta equação não se revelou satisfatória para representar as variações volumétricas em solos não saturados. Jennings e Burland (1962), comprovaram que a expressão de Bishop (1959), não traduzia o comportamento (relação entre índice de vazios e tensões efetivas) da maioria dos solos com um grau de saturação inferior a um determinado valor crítico.

De acordo com Bishop e Blight (1963), a variação da sucção não corresponde a uma mudança da tensão intersticial. Outros autores questionaram a formulação das tensões efetivas quando se consideram problemas de variação de volume ou resistência ao cisalhamento.

Segundo Alonso e Lloret (1985), ocorrem dificuldades para a obtenção do fator $X$ quando associado às deformações volumétricas, devido a que, caso ocorra redução das tensões efetivas, poderia ocorrer colapso ou expansão do solo, isto em função do termo 
da equação que for reduzido. Se for reduzida somente a sucção poderia ocorrer colapso, enquanto se somente é reduzida a tensão total, pode provocar expansão da massa do solo.

Aitchison (1967), considerou que devido a dificuldade de quantificar o valor do parâmetro $X$ e dada a variabilidade desse parâmetro, somente é possível obter um valor apropriado da tensão efetiva se se considera uma única trajetória para cada termo $\sigma$ ' e $\left(\mathrm{u}_{\mathrm{a}}-\mathrm{u}_{\mathrm{w}}\right)$, razão pela qual resulta desnecessário a quantificação do parâmetro $X$.

A diferença dos solos saturados para os não saturados é que o primeiro é constituído por duas fases (sólidos-água), enquanto o segundo é composto por três fases (sólidos-ar-água). Devido a este fator, os solos não saturados necessitam de novas formulações para o conceito de tensões efetivas, porque nos vazios ocorre a existência das fases ar e água. As diferenças das pressões nessas fases dão origem aos efeitos de sucção decorrentes de forças atrativas interpartículas (capilares e de adsorção).

As dificuldades encontradas na formulação de uma única equação levaram à adoção das variáveis de tensão como independentes. Dessa forma, as variações volumétricas foram reproduzidas em três eixos: dois correspondentes às variáveis de tensão independentes e um terceiro eixo correspondente ao índice de vazios.

A avaliação das propriedades do solo como mudanças de volume e resistência foram realizadas utilizando os conceitos de variáveis de estado (Matyas e Radhakrishna, 1968). As variáveis de estado de tensões são definidas como as variáveis físicas e independentes do solo, necessárias para definir seu estado de tensões.

Para solos não saturados são necessários além do estado de tensões e o índice de vazios, o grau de saturação e a estrutura do solo (Henkel, 1960).

No caso de solos argilosos normalmente adensados, considera-se que o estado do solo pode ser caracterizado pelo estado de tensões e o índice de vazios (ou teor de umidade). O estado de um elemento de solo pode ser representado graficamente por um ponto num espaço tridimensional definido por um sistema de eixos coordenados que correspondem aos parâmetros ou variáveis de estado. Desta forma, tensões associadas com carregamento mecânico ou geostático podem ser representados por qualquer das variáveis $\left(\sigma-\mathrm{u}_{\mathrm{a}}\right)$ ou $\left(\sigma-\mathrm{u}_{\mathrm{w}}\right)$, ou seja, tensão total menos pressão de ar nos vazios do solo ou tensão total menos pressão de água nos vazios do solo respectivamente. As tensões associadas com a pressão de poros é representada com a variável de sucção matricial $\left(\mathrm{u}_{\mathrm{a}}-\mathrm{u}_{\mathrm{w}}\right)$, e as mudanças de volume de solo associam-se aos dois estados de tensões independentes através do índice de vazios. 


\subsection{MÉTODOS DE IDENTIFICAÇÃO E CLASSIFICAÇÃO DE MATERIAIS EXPANSIVOS}

\subsubsection{Considerações Gerais}

A identificação e classificação de materiais expansivos é realizada com a finalidade principal de caracterizar de forma qualitativa o seu potencial expansivo. Esta classificação pode alertar os engenheiros durante as etapas preliminares de projeto, sobre os problemas potenciais destes materiais e proporcionar um apoio quanto à forma de tratamento e da necessidade de ensaios adicionais, usando técnicas quantitativas de determinação da expansão.

Uma primeira indicação do potencial expansivo pode ser verificada em campo, com base num exame rápido dos materiais expostos. Normalmente a aparência dos materiais argilosos expansivos, quando o material está seco, é bastante característica por apresentar empastilhamento, que ocorre quando o material é sujeito a variações de umidade, devido à exposição às intempéries, sofrendo uma desagregação física intensa e desintegrando-se superficialmente em pequenos blocos. A reação com água de um material supostamente expansivo pode também ser informativa, porque o grau de desintegração e desagregação que o solo sofre quando em contato com a água dá uma indicação geral de suas propriedades expansivas. Assim, materiais que se desagregam quase que imediatamente ao serem imersos em água e quando agitados são quase que totalmente dispersos, podem ser muito expansivos (Presa, 1984).

Existem vários critérios para a avaliação e determinação da expansibilidade de solos e rochas, que são baseados na composição mineralógica, no teor da fração argila, nos limites de consistência e nos ensaios de expansão e pressão de expansão (De Lamballerie, 1962; Horta da Silva, 1975).

Os métodos destinados a medir as variações volumétricas são variados e entre eles temos: a expansão livre (Holtz e Gibbs, 1956), mudanças de potencial de volume (Lambe, 1960) e os testes edométricos. 
Alguns critérios são disponíveis para classificação dos solos expansivos determinados a partir dos testes de identificação e geralmente são baseados nas propriedades índices dos materiais.

A Unified Soil Classification Sistem (USCS) e a American Association of State Highway and Transportation Officials (AASHTO), são métodos de classificação que consideram solos potencialmente expansivos os denominados dentro da sua terminologia como CL e CH para USCS e A6 e A7 para AASHTO, respectivamente

Outra classificação é a utilizada por Holtz e Gibbs (1956), para amostras inalteradas baseadas no conteúdo coloidal, IP e Limite de contração. Chen (1965), desenvolveu uma correlação entre a porcentagem de partículas que passam na peneira $\mathrm{N}^{0} 200$, limite de liquidez e a resistência à penetração standard (SPT). Seed et al., (1962), apresentaram uma classificação baseada na atividade e porcentagem da fração argila.

Estes métodos de classificação não podem ser usados como um procedimento de classificação padronizada, por terem sido realizados em diversas condições (amostras compactadas e inalteradas, diferentes teores de umidade inicial, números de amostras e tipos de materiais).

São inúmeros os métodos utilizados para a identificação e classificação de materiais expansivos, desde técnicas simples até muito sofisticadas. Estes métodos podem ser classificados em duas categorias, sendo estas: Técnicas diretas e Técnicas indiretas.

\subsubsection{Técnicas Indiretas}

Para uma identificação mais precisa e confiável deve-se recorrer a ensaios laboratoriais, sendo que para a determinação da constituição mineralógica dos materiais argilosos, geralmente os métodos mais usados são: Difração de Raios-X, Análise Térmica Diferencial (ATD), Análise Térmica Gravimétrica (ATG), Capacidade de Troca de Cátions (CTC), Microscopia Eletrônica, entre outros.

$\mathrm{Na}$ composição mineralógica leva-se em conta a natureza dos argilominerais presentes, em especial àqueles de rede cristalina expansiva (grupo das esmectitas). Este critério permite inferir se o material é passível ou não de apresentar expansão apreciável. 
Os argilominerais presentes num material argiloso podem ser facilmente identificados quando a amostra é pura, ou seja, possui apenas um tipo de argilomineral. As dificuldades para a identificação ocorrem, quando existem misturas de argilominerais de vários grupos, seja pela possibilidade de interferência nos diversos métodos de identificação, seja pelo fato de alguns argilominerais não serem detectáveis abaixo de determinado teor na amostra, teor deste, que pode variar dependendo do argilomineral e do método de ensaio.

Quando a amostra é pura, um único método pode ser suficiente para identificar o argilomineral presente, caso contrário, deve-se empregar vários métodos, que irão fornecer um conjunto de dados, que possibilitarão que a determinação da composição mineralógica seja mais precisa.

\subsubsection{Difração de Raios - X}

Neste método, a classificação ou identificação dos grupos de argilominerais, pode ser realizada a partir do valor medido para a distância interplanar basal do argilomineral, que foi previamente separado em suspensão aquosa como a "fração argila", e depositadas de forma orientada em lâminas de vidro. A utilização da Difração de Raios - X com registro gráfico, juntamente com as propriedades específicas de expansão da distância interplanar basal, induzida pela adição de substâncias orgânicas, como etilenoglicol e de transformações térmicas a $550^{\circ} \mathrm{C}$ de cada argilomineral, permite uma diferenciação dos grupos com mesma distância interplanar ou dentro de um mesmo grupo. Desta maneira, tal ferramenta se presta a estudos detalhados da estrutura cristalina de materiais. Comparando-se o padrão de difração de uma substância desconhecida com a de substâncias puras padrão, pode-se realizar a sua identificação de maneira relativamente rápida, o que faz com que a difração de Raios X seja um dos métodos mais utilizados na identificação de argilominerais.

\subsubsection{Análise Térmica Diferencial}

O ensaio denominado Análise Térmica Diferencial (ATD), é realizado mediante aumento de temperatura de uma amostra, sendo que as reações térmicas características de cada espécie mineralógica vão ocorrendo, permitindo a identificação dos argilominerais presentes. 
O método consiste no aquecimento, em velocidade constante, de uma argila, junto com uma substância termicamente inerte (geralmente óxido de alumínio-alfa ou coríndon), registrando as diferenças de temperatura entre o padrão inerte e a argila em estudo, em função da temperatura de aquecimento. Quando ocorrem transformações endotérmicas ou exotérmicas, estas aparecem como deflexões em sentidos opostos na curva termodiferencial ou termograma. Os recipientes ou blocos, em que são colocados o padrão e a argila, podem ser de níquel (para temperaturas até $1100^{\circ} \mathrm{C}$ ) ou de óxido de alumínio ou platina para temperaturas até $1600^{\circ} \mathrm{C}$ (Santos, 1989).

A identificação dos argilominerais puros, pode ser realizada pela posição, forma e intensidade dos picos endotérmicos e exotérmicos dos termogramas.

\subsubsection{Análise Térmica Gravimétrica}

De acordo com Santos (1989), a análise termogravimétrica consiste no aquecimento da argila à velocidade constante, sendo que o aparelho encontra-se conectado a uma balança, permitindo o registro das variações de massa em função da temperatura.

É um instrumento de pesquisa útil, principalmente quando se trabalha em paralelo com a Análise Térmica Diferencial.

\subsubsection{Capacidade de Troca de Íons}

Os argilominerais possuem a capacidade de troca de íons, ou seja, têm íons fixados na superfície, entre as camadas e dentro dos canais da estrutura cristalina, que podem ser trocados por outros íons em solução aquosa, sem que haja modificação na sua estrutura cristalina (Gomes, 1986).

A capacidade de troca de cátions (CTC) de um argilomineral pode ser o resultado do desequilíbrio de cargas resultante da substituição isomórfica na própria estrutura cristalina, das ligações químicas quebradas nas arestas das partículas e da substituição de hidrogênio por hidroxilas (Santos, 1989).

De acordo com este mesmo autor, a capacidade de troca de cátions nas esmectitas é devida a substituições isomórficas da camada tetraédrica; na caulinita principalmente a ligações quebradas, sendo que a menor cristalinidade desta aumenta também a 
capacidade de troca de cátions; nas ilitas e cloritas, se deve a ligações partidas e à troca de íons $\mathrm{K}^{+}$nas arestas das ilitas ou de íons $\mathrm{Mg}^{2+}$ na superfície das cloritas.

\subsection{Adsorção de Azul de Metileno}

Este ensaio permite caracterizar qualitativamente e em alguns casos quantitativamente os argilominerais presentes nas rochas. Como o azul de metileno não é adsorvido pelos minerais inertes, tais como, o quartzo, calcita, etc., possibilita determinar a atividade dos argilominerais nos solos e rochas, sem ter que separá-los do material restante. Alguns pesquisadores utilizam a adsorção do azul de metileno pelos materiais argilosos para avaliar o tipo e teor dos argilominerais presentes, para diversos fins, como exemplo, para avaliar as superfícies específicas e a capacidade de troca catiônica destes. Este ensaio têm sido utilizado para avaliar o potencial de expansibilidade dos solos e das rochas (Pejon, 1995; Pereira e Pejon, 1999).

A superfície total e a CTC podem ser determinadas pelo ensaio de azul de metileno denominado Método da Mancha proposto por Tran Ngoc Lan (1977).

\section{a) Método da Mancha}

Este ensaio é realizado, introduzindo quantidades sucessivas de azul de metileno na amostra que está em suspensão e em agitação permanente, até a saturação das partículas argilosas. A quantidade excedente de azul de metileno é detectada pelo teste da mancha. A quantidade de azul de metileno fixada é proporcional à massa seca da amostra ensaiada.

Segundo Jeremias (1991), as principais vantagens do ensaio são:

- Pode-se avaliar a quantidade e a atividade da fração argilosa $(<2 \mu \mathrm{m})$, sem a necessidade de separá-la do restante.

- A partir deste ensaio pode-se obter a capacidade de troca de cátions (CTC) e superfície específica (SE) da fração total do solo e da fração argila, além dos índices VB e Acb que indicam respectivamente a quantidade de azul de metileno adsorvido em 100 $\mathrm{g}$ de solo e em $100 \mathrm{~g}$ de argila contida no solo. 


\subsubsection{Microscopia Eletrônica}

De acordo com Mitchell (1993), o microscópio eletrônico é um instrumento valioso para o estudo de solos ou rochas, porque com os microscópios eletrônicos modernos, é possível uma resolução para distâncias menores que $0,01 \mathrm{~nm}$, podendo assim, ser realizado o estudo das pequenas partículas de argila.

Segundo Santos (1989), as informações que se podem esperar do estudo de uma argila ao microscópio eletrônico são:

a) Determinação da morfologia ou hábito cristalino das partículas constituintes;

b) Identificação dos argilominerais presentes;

c) Possibilidade de medida das dimensões das partículas para a distribuição da curva de distribuição granulométrica das mesmas;

d) Detectar a presença de pequenos teores de argilominerais não detectáveis por difração de raios-x;

e) Presença de materiais ou minerais amorfos, como alofanos;

f) Disposição e orientação das partículas na rocha, no estado em que se encontram na natureza;

g) Determinação do sinal e da distribuição das cargas elétricas na superfície da partícula, como exemplo, a adsorção de partículas negativas de ouro coloidal, por partículas de caulinita e montmorilonita.

Segundo Mitchell (1993), no Microscópio Eletrônico de Varredura, são emitidos elétrons secundários, que dão a forma superficial da amostra, produzindo uma imagem tridimensional. O MEV, tem uma amplitude magnífica de 20 vezes até 150.000 vezes, e uma profundidade de campo, cerca de 300 vezes maior do que do microscópio ótico.

Pejon et al. (1997), mostraram a aplicação desta técnica no estudo da expansão de rochas sedimentares de granulometria fina.

\subsubsection{Limites de Atterberg}

A expansibilidade pode ser analisada baseando-se nos Limites de consistência, a partir dos valores dos limites de liquidez (ABNT: NBR - 6459/80), plasticidade (ABNT: NBR - 9180/82) e o índice de plasticidade (IP). Os valores resultantes destes ensaios permitem uma avaliação quantitativa de potencialidade de expansão (Frazão, 1981). 
Para os materiais argilosos, utiliza-se a consistência como uma forma de determinar os estados possíveis, em que podem ser encontrados. Os limites entre cada estado, foram definidos em função do teor de umidade, e empiricamente estabelecidos por Albert Mauritz Atterberg, na Suécia em 1911, daí serem conhecidos como Limites de Atterberg (Carvalho, 1997). Estes limites representam a transição entre os estado líquido-plástico-semi-sólido-sólido.

De acordo com o mesmo autor, sabe-se que os Limites de Atterberg são uma função da quantidade de água absorvida na superfície das partículas do solo. Esta superfície aumenta muito com a diminuição do tamanho das partículas, por exemplo: a montmorilonita têm uma superfície específica (da ordem de $800 \mathrm{~m}^{2} / \mathrm{g}$ ), muito maior que da caulinita ( $\cong 15 \mathrm{~m}^{2} / \mathrm{g}$ ), assim, a quantidade de água absorvida aumenta de acordo com a quantidade de pequenas partículas, e consequentemente, o comportamento do material, vai estar diretamente relacionado com este aspecto.

\subsubsection{Atividade}

Um meio de avaliar a expansibilidade dos materiais argilosos é através do índice de atividade de Skempton (1953), que corresponde à razão: índice de plasticidade de Atterberg / \% da fração inferior a $2 \mu \mathrm{m}$. O autor considerou 5 grupos de solos, com base nos valores do índice de atividade em função do tipo de argilomineral e afirma que a maior atividade dos argilominerais fornece um maior potencial de expansão:

Inativos, com atividade $<0,5$

Inativos, com atividade entre $0,5-0,75$;

Normalmente ativos, com atividade entre $0,75-1,25$;

Ativos, com atividade entre 1,25-2;

Ativos, com atividade $>2$.

Williams e Donaldson (1980), estabeleceram uma classificação da expansibilidade de solos, com base nos índices de Skempton (Figura 15). 


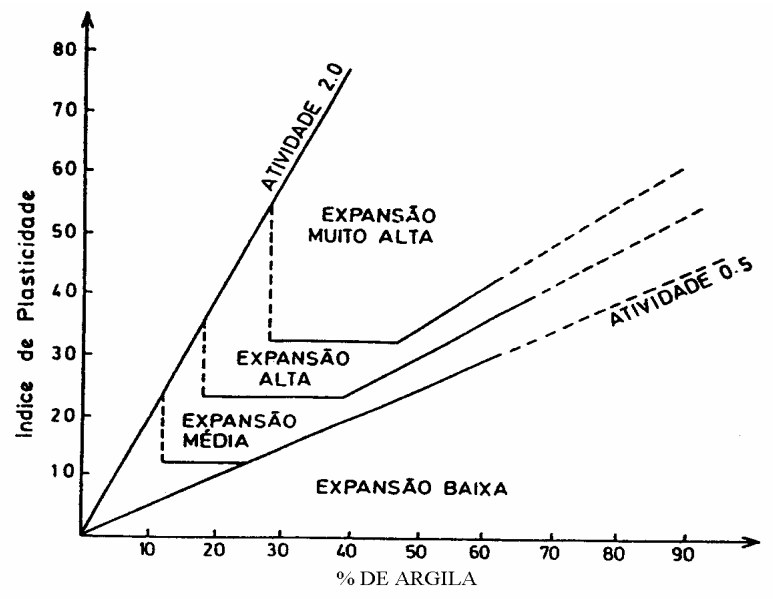

FIGURA 15. Classificação da expansibilidade de argilominerais e materiais argilosos segundo Williams e Donaldson, 1980.

Pereira e Pejon (1999) propuseram com base em dados de expansão de materiais da Formação Guabirotuba, um gráfico semelhante ao da Figura 15, mas utilizando no lugar do Índice de Plasticidade, o valor da adsorção de azul de metileno (VB) versus \% de argila (Figura 16). Assim, foi possível delimitar áreas onde predominavam materiais com potenciais expansivos: muito alto, alto, médio e baixo. Os limites extremos utilizados neste gráfico são retas geradas para a montmorilonita e para a caulinita. Tais retas foram obtidas a partir da mistura de porcentagens destes argilominerais puros com areia e pelo valor determinado de VB para cada ponto. 


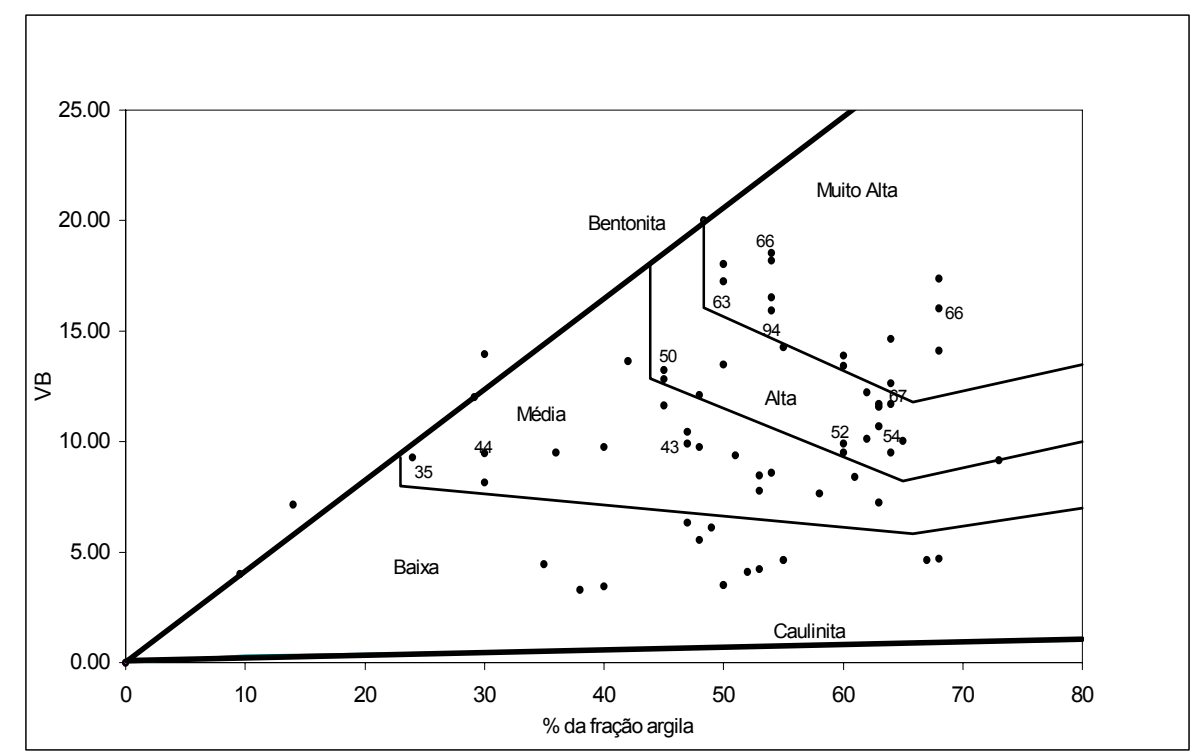

FIGURA 16. Representação dos dados de VB versus porcentagem da fração argilosa, com os respectivos valores de Expansão Livre (\%) determinados para os 11 materiais argilosos e a separação de porções do material que apresentam potenciais expansivos distintos.

\subsubsection{Técnicas Diretas}

As técnicas diretas incluem todos os métodos que determinam quantitativamente as características de mudanças de volume de materiais expansivos (a expansão e pressão de expansão) (Presa, 1984).

Estes ensaios têm importante aplicação geotécnica porquê às variações de volume e pressões desenvolvidas pelos materiais argilosos, quando em contato com a água, podem causar grandes prejuízos às obras de engenharia. Os principais mecanismos que irão condicionar o comportamento geotécnico das rochas são as variações no teor de água, a descompressão dos terrenos, e as modificações de natureza química, sendo que o primeiro muitas vezes, é o principal causador da expansão e do desenvolvimento das pressões de expansão.

São técnicas diretas aquelas que visam determinar a expansão e a pressão de expansão através de metodologias que reflitam as condições às quais os materiais estarão sujeitos (Ignatius e Frazão, 1990).

Nos ensaios de expansão, procura-se medir as variações de volume de material, sujeitos ou não a sobrecargas. 
Frazão e Goulart (1976), consideram que sendo as pressões de expansão um parâmetro decisivo na fenomenologia da desagregabilidade, é de grande utilidade sua mensuração.

\subsubsection{Expansão Livre}

Os ensaios de expansão livre medem a variação de espessura da amostra, em função do tempo, em relação a sua altura inicial, quando é colocada dentro de um recipiente com água (Figura 17).

Um dos métodos utilizados para a determinação da expansão livre (Campos, 1989), consiste em acondicionar corpos de prova cilíndricos em células do tipo edométrico convencional, podendo ser ou não confinadas em um anel de PVC rígido. No topo dos corpos de prova coloca-se um relógio comparador (micrômetro), sustentado por um braço mecânico. Estes relógios permitem leitura direta de até 0,01 $\mathrm{mm}$, com capacidade para até $10 \mathrm{~mm}$. Após os corpos de prova estarem acondicionados na célula, ajusta-se o relógio comparador e adiciona-se água destilada. As deformações observadas no relógio, são anotadas em intervalos de tempo, que obedecem a uma progressão geométrica de razão dois. Os corpos de prova são pesados antes e após o ensaio. Anota-se também, sua altura inicial (antes do ensaio).

Este ensaio segue as recomendações da International Society for Rock Mechanics - I.S.R.M. (1972, 1989).

A expansão livre é calculada pela seguinte relação:

$\mathrm{E}=\frac{\Delta \mathrm{H}}{\mathrm{H}} * 100$

Onde: $\mathrm{E}=$ expansão livre uniaxial $(\%) ; \Delta \mathrm{H}=$ máximo acréscimo de altura e $\mathrm{H}=$ altura inicial do corpo de prova $(\mathrm{mm})$.

Os resultados dos ensaios são retratados na forma de gráficos, obtidos através dos valores de deformação (\%) versus tempo (h). 


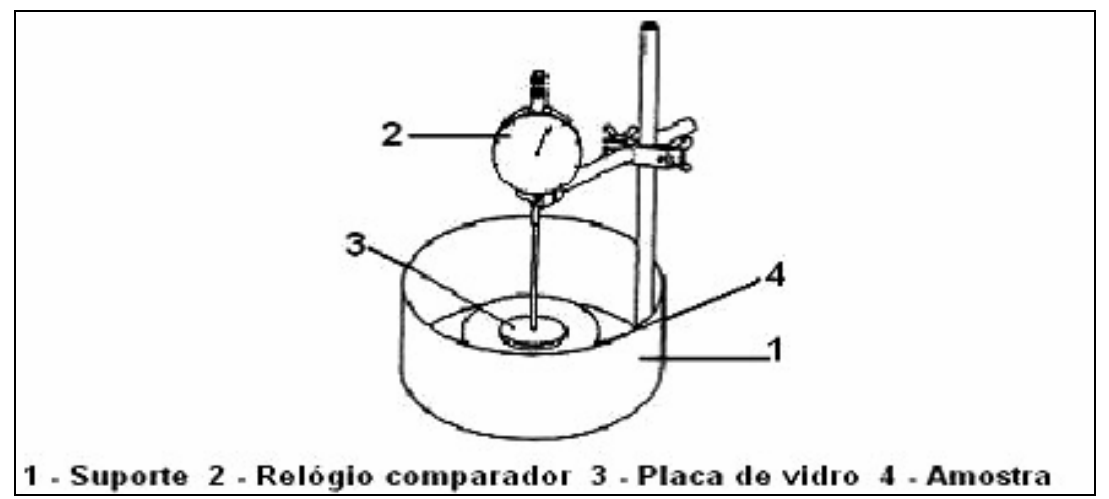

FIGURA 17. Esquema do ensaio de Expansão Livre (ISRM, 1989).

Pereira e Pejon (1999), realizaram ensaios de expansão livre para onze materiais argilosos da Formação Guabirotuba, sendo que os resultados obtidos foram avaliados em conjunto com os resultados de ensaios de pressão de expansão e de caracterização, permitindo assim, a determinação de áreas com diferentes potenciais à expansão. Para tal propósito, utilizaram materiais na umidade natural, com e sem anel de confinamento e secas ao ar. Foram utilizados anéis nas amostras úmidas para a obtenção de um parâmetro de comparação com os resultados sem anéis, a fim de observar se o confinamento lateral implicaria num aumento significativo de deformação, já que os ensaios nas amostras secas ao ar foram realizados dentro do anel, devido ao material desagregar-se rapidamente quando em contato com a água.Os resultados de deformação para as amostras com umidade natural sem anel foram da ordem de 0 a 1,43\%, para as amostras com umidade natural com anel de 0,24 a 2,42\% e para as amostras secas ao ar de 35,67 a $93,98 \%$. A expansão mais baixa das amostras sem anel se deve ao fato do material apresentar muitas fraturas, e com a entrada da água tender primeiramente a se acomodar ao invés de expandir. Já a diferença entre as amostras com secagem e úmida é marcante.

\subsubsection{Pressão de Expansão}

Segundo Philipponnat (1991), pressão de expansão é a pressão que o material expansivo exerce, quando a expansão é impedida.

De acordo com Jeremias (1991), as pressões de expansão desenvolvem-se, quando a expansão devido a umidificação das rochas está total ou parcialmente impedida, porque do contrário, expandiriam-se livremente (aumentariam de volume), sem gerar 
tensões. Assim, as variações de umidade dos terrenos, são por vezes, a principal causa da expansão e do desenvolvimento de pressões de expansão.

Existem vários métodos para a determinação da pressão de expansão (Frazão, 1981), sendo que os ensaios edométricos estão entre os mais utilizados para estudar a variação volumétrica dos materiais expansivos.

\subsection{Determinação da Pressão de Expansão a partir de Ensaios Edométricos Convencionais}

\section{a) Método da amostra a volume constante}

Um dos métodos propostos pela Associação Internacional de Mecânica das Rochas (ISRM, 1989) para determinação da pressão de expansão é a volume constante. Neste método utiliza-se um corpo de prova que é submetido a uma pressão vertical préestabelecida, sendo em seguida inundado. A pressão aplicada pode ser apenas o suficiente para ajuste do sistema, ou, corresponder à pressão vertical estimada do material "in situ”. O teste mede a pressão axial necessária para forçar uma amostra de rocha indeformada a manter uma altura constante quando confinada e imersa em água.

Pereira e Pejon (1999), obtiveram valores de pressão de expansão para materiais argilosos da Formação Guabirotuba na região do Alto Iguaçu-PR, da ordem de 1,6 a $34,2 \mathrm{kPa}$ para amostras ensaiadas na umidade natural e 158 a $4187 \mathrm{kPa}$ para amostras submetidas à secagem. As amostras com umidade natural apresentaram pressões de expansão baixas em comparação com as secas ao ar, provavelmente por possuírem graus de saturação elevados, superiores à $80 \%$. Os valores de pressão de expansão estão intimamente ligados aos teores de umidade nas quais as amostras foram ensaiadas, podendo variar caso sejam modificados estes teores. A partir da análise destes resultados, de ensaios de expansão livre e de caracterização, foi possível a elaboração da "Carta de Predisposição à Ocorrência de Problemas Expansivos" para os materiais da área.

\section{b) Ensaio edométrico direto}

Segundo Presa (1984), é o ensaio considerado mais simples para a determinação da expansão, portanto, um dos mais utilizados. É realizado colocando-se uma amostra 
indeformada na célula edométrica, com teor de umidade natural e, submetendo-a a uma carga correspondente ao valor de sobrecarga do terreno $\left(\mathrm{p}_{\mathrm{o}}\right)$. Caso o ensaio esteja sendo realizado para algum projeto específico, deve-se adicionar à amostra uma carga adicional $(\Delta \mathrm{p})$, correspondente à solicitação imposta pela estrutura que será construída.

Após a consolidação da amostra, sob as cargas a que está sujeita, adiciona-se água à célula edométrica, deixando a amostra expandir até a estabilização. Deste ponto em diante, aumenta-se a carga como se fosse um ensaio de consolidação normal até voltar à altura original. Da curva $e$ vs $\log p$ obtém-se o valor de $\Delta$ e correspondente a expansão da amostra (Figura 18).

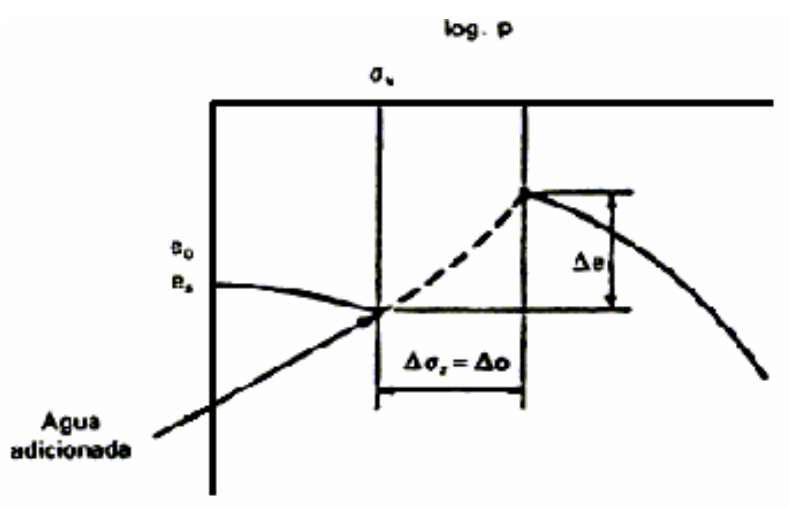

FIGURA 18. Representação do ensaio edométrico direto.

\section{c) Ensaios edométricos múltiplos}

De acordo com Presa (1984), no ensaio edométrico múltiplo se utilizam várias amostras com umidade natural, montando-as no edômetro convencional com diferentes sobrecargas. Em seguida, são inundadas e medidas suas expansões depois de estabilizadas. Isto equivale a realizar ao mesmo tempo vários ensaios do tipo acima referido. Geralmente os resultados são apresentados por meio de duas curvas, uma que corresponde a variação dos índices de vazios das amostras com conteúdo de umidade natural e a outra a variação dos índices de vazios para as amostras inundadas (Figura 19). 


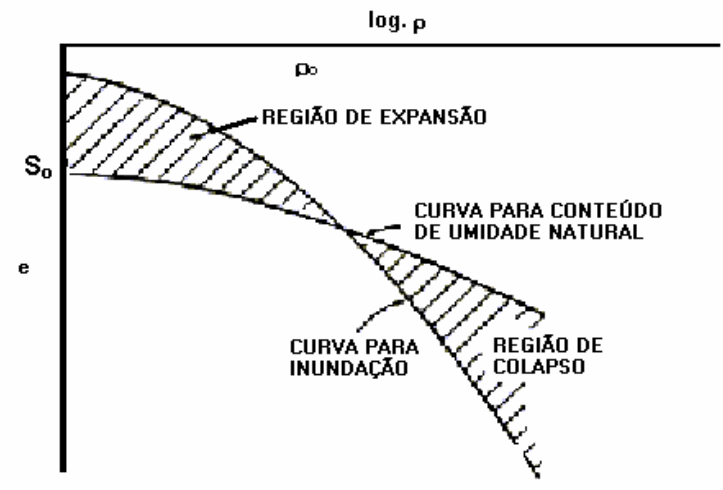

FIGURA 19. Ensaio edométrico múltiplo.

\section{d) Ensaios edométricos duplos}

Neste ensaio são utilizadas duas amostras indeformadas, retiradas adjacentes, na mesma profundidade, que vão sendo carregadas progressivamente em dois edômetros distintos. Uma das amostras é ensaiada com teor de umidade natural, desde o início do ensaio, até o final, e a outra ensaiada com acesso de água. A amostra ensaiada com água, deixa-se expandir com a carga inicial do ensaio, até estabilizar. Em seguida, as duas amostras são sujeitas a aumento de carga, de acordo com o ensaio de consolidação normal.

\section{e) Ensaio edométrico simples}

Segundo Jennings (1973), no ensaio edométrico duplo, a amostra ensaiada no teor de umidade natural, se destina, exclusivamente, para a determinação do índice de vazios inicial $\left(\mathrm{e}_{\mathrm{o}}\right)$, sob a tensão vertical, na profundidade de retirada da amostra $\mathrm{p}_{\mathrm{o}}$. Neste caso, pode-se determinar o valor de $\mathrm{e}_{\mathrm{o}}(\mathrm{po})$, colocando no edômetro apenas uma amostra com teor de umidade natural até a tensão $p_{o}$, depois descarrega até a pressão inicial. Seria então adicionado água à amostra, que expandiria até a estabilização.

Segundo Horta da Silva (1975) as vantagens deste método estão na eliminação do erro de ajuste das curvas (teor natural e saturada), e na possibilidade de duplicar o número de amostras por local de estudo. 


\subsection{MÉTODOS PARA A DETERMINAÇÃO DA SUCÇÃO}

\subsubsection{Considerações Gerais}

De acordo com Brekke (1965), a avaliação da expansibilidade dos materiais deveria ser realizada "in situ" para que os fatores internos não fossem afetados e pela vantagem de se ter uma visão de conjunto dos fatores externos criados pela obra.

Devido às dificuldades da realização em campo deste método, têm-se realizado em laboratório ensaios padronizados, utilizando corpos de prova indeformados ou remoldados.

Apesar de apresentarem restrições, os ensaios de laboratório são de grande interesse por permitirem obter pelo menos o potencial relativo de expansão. Os resultados dos ensaios não podem entretanto, serem tomados como totalmente representativos da situação real que se desenvolve "in situ", mesmo sob condições similares de carregamento, de conteúdo de água, etc. Estes ensaios apenas simulam processos que poderão ocorrer no local (Frazão e Goulart, 1976).

Autores como Escario (1969); Escario e Sáez (1973); Kassif e Ben Shalom (1971), têm criticado os ensaios convencionais que são realizados com inundação total das amostras nos ensaios de expansão, por considerarem que esta situação geralmente não reflete às condições reais do comportamento dos materiais "in situ".

Em Geotecnia, os ensaios de sucção são geralmente realizados com a finalidade de estimar a sucção do material sem sobrecarga e em determinadas condições de umidade, índices de vazios e estrutura. São também realizados para a determinação da curva de sucção versus teor de umidade.

Segundo Wolle e Carvalho (1988), são dois os objetivos básicos para a realização de medições da pressão de sucção:

a) Determinação da relação entre sucção e teor de umidade, ou seja, da "curva característica de umidade", que é realizada a partir de amostras em laboratório;

b) Determinação da pressão de sucção numa dada situação, em campo ou sobre amostras em laboratório.

Todas as técnicas para medida de sucção requerem uma troca de água entre o material e o sistema de medição. 
Segundo Vilar et al. (1995), as medidas de sucção, tanto em laboratório como em campo, podem ser realizadas através de diversos métodos, que apresentam vantagens e limitações.

Apesar de que, no contexto da Mecânica dos Solos, prevaleça a opinião de que é a sucção matricial que governa o comportamento mecânico e hidráulico do solo, deve-se reconhecer que em algumas situações, como no caso dos materiais expansivos, deva ser considerado o papel da sucção osmótica (Vilar et al., 1995).

A sucção matricial pode ser obtida por diversas técnicas, tanto em campo, como em laboratório. Em campo, uma maneira simples de obtenção da sucção matricial, é através da utilização de tensiômetros simples ou com transdutores de pressão, que fornecem medidas mais precisas e psicrômetros. Em laboratório, utiliza-se a membrana de pressão e o funil de placa porosa (São Mateus, 1994).

Geralmente, as medidas de sucção matricial em laboratório utilizam o princípio da técnica de translação de eixos, que comumente é empregada em equipamentos que possuem placa ou membrana de pressão, e são equipados com pedras porosas de alto valor de entrada de ar ou de membranas de celulose.

\subsubsection{Técnicas utilizadas em equipamentos para a determinação da sucção}

\subsubsection{Considerações Gerais}

A interação sólidos-água-ar e suas interfaces trazem enormes dificuldades tanto analíticas quanto de controle durante os ensaios em solos não saturados. Nesse sentido, a técnica de translação de eixos e o desenvolvimento de pedras de alto valor de entrada de ar, muito contribuíram para refinar a experimentação com solos não saturados, onde se deseja ter um controle do papel da sucção no comportamento destes solos. Deve-se reconhecer ainda, a contribuição de técnicas que empregam princípios osmóticos na instalação da sucção nas amostras ensaiadas e técnicas que empregam o equilíbrio na fase vapor, sendo que estas, geralmente, permitem atingir valores elevados de sucção (Vilar et al., 1995).

A seguir será realizada uma descrição das técnicas de translação de eixos, osmótica e que emprega o equilíbrio na fase vapor. 


\subsubsection{Técnica de Translação de Eixos}

A técnica de translação de eixos foi introduzida na Mecânica dos Solos por Hilf (1956), e parte do pressuposto de que a água e as partículas sólidas são incompressíveis, pelo menos nas faixas de tensões utilizadas usualmente na prática da Engenharia.

A técnica consiste basicamente na mudança do referencial de pressão (a pressão atmosférica), ou seja, uma translação de eixos. Para que isto seja possível, a pressão de ar é aumentada, o que leva a um aumento igual da pressão de água, permanecendo a diferença ua - uw, ou seja, permanece a sucção e a pressão de água é aumentada (parte de valores baixos, impossíveis de medir) levando a valores mensuráveis pelos equipamentos convencionais de medida (Vilar, 1997).

Esta técnica foi desenvolvida devido às dificuldades na realização de ensaios em solos não saturados, onde freqüentemente têm-se pressões superiores a $100 \mathrm{kPa}$. Sucções maiores que 1 atm (100 kPa) provocam cavitação (formação de bolhas de ar) na água dos sistemas de medida.

Para que a técnica possa ser colocada em prática, é necessário contar com placas porosas especiais que permitam o fluxo de água e não o fluxo de ar. Para que isto ocorra, estas placas são fabricadas com poros de pequenas dimensões. A sucção imposta no material fica limitada à pressão de entrada de ar das placas porosas, que podem atingir pressões de até 15 bar (Vilar, 1997).

Como ocorre a movimentação de solutos através da placa porosa, a partir desta técnica, o que se controla ou se impõe à amostra é a sucção matricial. É utilizada nas câmaras de pressão para definir as características de retenção de água pelo solo.

A técnica pode apresentar algumas vantagens e desvantagens, que serão mostradas a seguir:

Quanto às vantagens que esta técnica oferece pode-se enumerar:

1) Proporciona medição direta da sucção, que equivale à pressão de ar aplicada artificialmente;

2) Torna possível a medição de sucções maiores que $100 \mathrm{kPa}$, com limite de 1.500 $\mathrm{kPa}$ e de até $10.000 \mathrm{kPa}$ quando utilizada conjuntamente com a placa de pressão uma membrana de celulose (membrana de pressão);

3) Está comercialmente disponível. 
Quanto às desvantagens que a técnica apresenta pode-se dizer que:

1) É viável desde que exista uma continuidade da fase de ar através da amostra de solo, isto é, que todos os vazios de ar estejam interconectados (Olson e Langfelder, 1965).

2) Caso exista ar ocluído, a compressibilidade da mescla água - ar é elevada e pode gerar uma super estimação dos valores de sucção (Bocking e Fredlund, 1980). Neste caso deve-se cogitar para graus de saturação elevados, ou seja, para baixas sucções, onde existe uma maior quantidade de água, maior possibilidade de ar ocluído e descontinuidade da fase ar, a possibilidade de valores incorretos de sucção, a partir da técnica de translação de eixos (Vilar, 1997.)

3) Não é recomendável para medições de sucção menores que $10 \mathrm{kPa}$ (Jiménes Salas, 1993; Libardi, 1995). A permeabilidade do ar num solo não saturado é praticamente nula quando o grau de saturação é aproximadamente de 75 a $85 \%$ (Komornik et al. (1980); Bocking e Fredlund (1980), o que possibilita o aparecimento de ar ocluído (Barden (1965); Matyas (1966); Bocking e Fredlund (1980);

4) O equipamento é relativamente caro.

Este método vêm sendo utilizado de maneira bem sucedida para controle da sucção em ensaios e no campo da Geotecnia vêm sendo aplicado para a determinação das propriedades de retenção de água no solo (Richards, 1940), cisalhamento direto (Escario, 1989), compressão triaxial (Bishop e Donald, 1961; Ho e Fredlund, 1982), compressão confinada (Escario e Sáez, 1973; Fredlund e Morgenstern, 1976) e ensaios de permeabilidade (Gardner, 1956; Olson e Daniel, 1981).

\subsubsection{Técnica Osmótica}

Esta técnica foi inicialmente desenvolvida por Biólogos (Lagerwerff et al., 1961) e posteriormente, utilizada por cientistas que trabalham com solos (Zur, 1966).

Este procedimento baseia-se no princípio termodinâmico que afirma que a pressão hidrostática incrementa o potencial de água, enquanto que o soluto diminui. Assim, uma solução confinada em contato com água pura livre através de uma membrana semipermeável perfeita estará em equilíbrio quando a pressão hidrostática aplicada à 
solução seja igual à sucção osmótica (Low e Anderson, 1958). Esta é por definição a pressão osmótica, que depende evidentemente da concentração da solução.

Caso a água pura livre seja substituída por um solo úmido, o potencial total ou a energia livre da água na solução pode ser menor ou maior do que a água do solo. Essa diferença de potencial tenderia a movimentar a água (do solo ou da solução) de maior para o menor potencial através da membrana até que um novo equilíbrio fosse estabelecido.

Na prática, a solução utilizada para estes fins denomina-se solução osmótica que é geralmente composta com um soluto denominado polietileno de glicol (PEG), que é caracterizado por uma baixa reação química e uma alta solubilidade com a água.

Uma das características mais importantes com relação ao método é o tamanho das moléculas do PEG. Assim, ao ser colocada uma solução (com uma concentração determinada) de PEG em contato com um solo úmido através de uma membrana semipermeável, a pressão osmótica é gerada devido à impossibilidade das moléculas do PEG atravessarem a membrana por serem maiores (em relação as moléculas de água), permitindo somente o fluxo de água, que é atraída pela maior concentração da solução.

Os tamanhos das moléculas do PEG são definidos pelo seu peso molecular. As soluções mais utilizadas para estes fins são as denominadas PEG com pesos moleculares de 6.000 (PEG 6.000) e 20.000 (PEG 20.000).

A magnitude da pressão osmótica desenvolvida vai depender da concentração do PEG na solução (expressa em peso seco de PEG por litro de água destilada a $25^{\circ} \mathrm{C}$ ) que se encontra em contato com o solo. Conseqüentemente, a variação da concentração da solução torna possível o controle do teor de umidade ou da pressão osmótica (Kassif e Ben Shalom, 1971).

A calibração da relação pressão osmótica versus concentração da solução é obtida através da técnica do controle da sucção por imposição da umidade relativa. Soluções com várias concentrações de PEG são colocadas em uma atmosfera controlada (dessecador de vazio) contendo uma solução salina. Uma vez estabelecida a condição de equilíbrio de vapor entre a solução PEG e a solução salina, a umidade relativa imposta é relacionada com a sucção através da lei de Kelvin.

Segundo Williams e Shaykewich (1969), observa-se que os valores de sucção para esta relação podem chegar até um valor máximo de $1.500 \mathrm{kPa}$, para concentrações crescentes de 0 para 28g de PEG por 100g de solução, tanto para PEG 6.000 como para 
PEG 20.000. Delage, Howart e Cui (1997), estenderam a faixa de pressão osmótica para um valor de $10.000 \mathrm{kPa}$.

De acordo com Kassif e Ben Shalom (1971), as membranas empregadas usualmente são permeáveis aos íons do soluto da água do solo, que podem passar da água do solo à solução até atingir o equilíbrio, e devido a isto, o sistema não mede a sucção total mas unicamente a sucção matricial

Esta técnica apresenta algumas vantagens e desvantagens, que serão descritas abaixo. Dentre as vantagens pode-se dizer que:

1) Se comparada com o método de translação de eixos, a maior vantagem é que o solo permanece quase em condição natural, visto que não precisa aplicação de pressão de ar na amostra. A pressão de água $\left(\mathrm{u}_{\mathrm{a}}\right)$ é negativa tal como se apresenta na natureza (Cui e Delage, 1996), e com um fluxo lento através de amostra de forma lenta e uniforme (Komornik, Livneh e Smucha, 1980);

2) Pode medir valores de sucção até $10.000 \mathrm{kPa}$;

3) Não superestima os valores de sucção por causa de "ar ocluído", em medições feitas em solos com alto grau de saturação, como no método de translação de eixos (Delage, Vicol e Suraj de Silva, 1992);

Como qualquer uma das técnicas, também pode apresentar algumas desvantagens, tais como:

1) As membranas precisam de um peso molecular cut-off (MWCO) adequado em relação ao peso molecular do PEG, quando submetidas as pressões hidrostáticas. Caso contrário podem tornar-se permeáveis às moléculas do PEG (Komornik, Livneh e Smucha, 1980);

2) As membranas são sensíveis às bactérias ou microorganismos, portanto precisam de um tratamento com um antibiótico de grande espectro na solução (Zur, 1966; Delage, Vicol e Suraj de Silva, 1992). Nessas condições o período de vida de uma membrana com uso contínuo é de aproximadamente um mês;

3) Os equipamentos baseados neste método não são comercialmente disponíveis;

4) Existe a necessidade de um controle de temperatura $\left(20^{\circ} \mathrm{C} \pm 0,1\right)$ para as soluções durante o ensaio.

Kassif e Ben Shalom (1971), foram os primeiros a adaptarem a técnica para ensaios em Geotecnia, num edômetro para estudos de solos expansivos. 
A técnica de controle de sucção não é utilizada comumente na Geotecnia, porém, pode ser uma boa alternativa pelas vantagens oferecidas em relação aos métodos tradicionais.

Para esse objetivo, o método tem sido adaptado a diversos arranjos de equipamentos para ser usados em ensaios na determinação das propriedades de retenção de água nos solos (Zur, 1966; Pointer, 1966; Graham Bryce, 1967; Williams e Shaykewich, 1969; Cui e Delage, 1996), compressão confinada (Kassif e Ben Shalom, 1971; Delage, Vicol e Suraj de Silva, 1992; Dineen e Burland, 1995), compressão triaxial (Komornik, Livneh e Smucha, 1980; Delage et al.,1987; Cui e Delage, 1996).

\subsubsection{Técnica de controle de Sucção por Imposição da Umidade Relativa}

De acordo com Ridley e Wray (1996), a quantificação da sucção em solos não saturados apresenta uma série de dificuldades experimentais e em alguns casos é necessário o uso de técnicas indiretas que relacionam a sucção com outras propriedades como temperatura, umidade relativa, resistividade, teor de umidade, entre outros.

A técnica consiste em determinar a sucção total através da pressão parcial de vapor de água em equilíbrio com a água do solo.

A relação entre a pressão relativa de vapor de água e a sucção é dada pela expressão:

$\mathrm{u}_{\mathrm{a}}-\mathrm{u}_{\mathrm{w}}=\frac{\mathrm{RT}}{\mathrm{Mg}} \ln \frac{\mathrm{P}}{\mathrm{Po}}$

Onde: $\mathrm{u}_{\mathrm{a}}, \mathrm{u}_{\mathrm{w}}$ : pressão do ar e da água respectivamente; $\mathrm{R}$ : constante de gases perfeitos $\left(8,3143 \mathrm{Jmol} \mathrm{K}^{-1}\right)$; T: temperatura absoluta $\left(293^{\circ} \mathrm{K}-20^{\circ} \mathrm{C}\right)$; M: massa molar da água $\left(18,016 \mathrm{gmol}^{-1}\right) ; \mathrm{g}$ : aceleração gravitacional $\left(9,81 \mathrm{~ms}^{-2}\right) ; \mathrm{P} / \mathrm{Po}$ : umidade relativa, que é a relação entre a pressão parcial de vapor $(\mathrm{P})$ e a pressão de vapor de saturação (Po) e RT/Mg: $137.837 \mathrm{kPa}$.

As vantagens e desvantagens da técnica estão relacionadas a seguir.

Quanto às vantagens pode-se citar:

1) Segundo Delage, Howart e Cui (1997), a técnica pode ser utilizada para medições de sucção elevadas e teoricamente não apresenta um limite superior; 
2) O efeito de sucção é produzido sob condições naturais, não sendo imposta nenhuma pressão na fase gasosa;

3) Serve como medida padrão da sucção total dos solos e utiliza-se como referência e calibração de equipamentos baseados em outros métodos de medição. 4) É considerada uma técnica simples, de fácil operação e o equipamento utilizado para determinar a curva de retenção é disponível comumente em qualquer Laboratório de Mecânica dos Solos;

Quanto às desvantagens pode-se dizer que:

1) Necessita de controle de temperatura $\left(20 \pm 0,1^{\circ} \mathrm{C}\right)$;

2) De acordo com Blight (1967), o tempo de equilíbrio da umidade é demorado, podendo alcançar de 100 a 250 dias em umidades relativas superiores ao $85 \%$;

3) Apresenta algumas limitações para sucções menores de $10.000 \mathrm{kPa}$.

A técnica do controle de sucção por imposição da umidade relativa é um método indireto e primeiramente foi desenvolvida por cientistas do solo, sendo que a primeira aplicação em ensaios de Geotecnia, foi realizada por Esteban e Sáez (1988), que adaptaram a técnica a um edômetro.

Segundo Delage, Howart e Cui (1997), a técnica de controle de sucção por imposição da umidade relativa além de ser utilizada como medida padrão, de referência e calibração de outros equipamentos, tem sido aproveitada na determinação das propriedades de retenção de água. Vêm sendo utilizada também para medição da deformabilidade de solos através de adaptações para ensaios de compressão confinada (Esteban e Sáez, 1988).

\subsubsection{Métodos mais utilizados para a determinação da sucção}

Os ensaios de sucção são realizados freqüentemente com a finalidade de estimar a sucção do solo sem sobrecarga e em determinadas condições de umidade, índices de vazios e estrutura, além de algumas vezes serem utilizados para a determinação da curva de sucção versus teor de umidade (Presa et al., 1988).

Existem vários métodos de ensaio utilizados para a medida de sucção nos solos e a Tabela 04, mostra uma síntese destes métodos. 
TABELA 04. Síntese de métodos utilizados para a determinação de medida de sucção nos solos (Vilar, 2000)

\begin{tabular}{|c|c|c|c|c|}
\hline MÉTODO & REALIZADO & TIPO DE SUCÇÃO & $\begin{array}{l}\text { FAIXA DE MEDIDA } \\
(\mathrm{kPa})\end{array}$ & OBSERVAÇÃO \\
\hline Placa de sucção & Laboratório & Matricial & 0 a 70 & $\begin{array}{l}\text { - Para baixas sucções, onde a precisão das panelas é } \\
\text { limitada; } \\
\text { - Sucção aplicada diretamente à amostra. }\end{array}$ \\
\hline Placa de pressão & Laboratório & Matricial & $\begin{array}{c}0 \\
\mathrm{a} \\
1.500\end{array}$ & $\begin{array}{l}\text { Emprega a técnica de translação de eixos.; } \\
\text { - A capacidade depende da pedra porosa (pressão de entrada } \\
\text { de ar); } \\
\text { Continuidade da fase ar. }\end{array}$ \\
\hline Membrana de pressão & Laboratório & Matricial/Total & até 10.000 & $\begin{array}{l}\text { Emprega a técnica de translação de eixos; } \\
\text { - Emprega membrana de celulose (seletividade). }\end{array}$ \\
\hline Papel filtro & Laboratório & Matricial e Total & Todos os valores & $\begin{array}{l}\text { Necessita precisão máxima na pesagem. } \\
\text { - A determinação da sução depende do contato com o solo } \\
\text { (garantir o contato parece problemático); } \\
\text { - Calibração, fungos. }\end{array}$ \\
\hline Tensiômetro & Laboratório e Campo & Matricial & 0 a 70 & $\begin{array}{l}\text { Tempos de resposta em função da condutância da pedra } \\
\text { porosa; } \\
\text { - Tensiômetros Osmóticos; } \\
\text { - Tensiômetros de alta capacidade (medem pressões abaixo } \\
\text { de }-1 \text { atm), tirando partido da elevada resistência à tração } \\
\text { da água. }\end{array}$ \\
\hline Blocos porosos & Laboratório e Campo & Matricial & 10 a 1.000 & $\begin{array}{l}\text { - Condutividade elétrica de materiais porosos (gesso, fibra } \\
\text { de vidro, etc); } \\
\text { - Histerese pronunciada; mais sensível às altas sucções; } \\
\text { - Longo tempo de resposta; } \\
\text { - Fácil deterioração do material; } \\
\text { Resistência elétrica (ohms x sucção). }\end{array}$ \\
\hline Psicrômetros & Laboratório e Campo & Total e Osmótica & 100 a 8.000 & $\begin{array}{l}\text { Mais recomendado para laboratório; } \\
\text { Depende de rigoroso controle da temperatura, } \\
\text { principalmente nas baixas sucções; } \\
\text { Sucção osmótica: mede sucçáo de extrato da solução do } \\
\text { solo (confiabilidade precária). }\end{array}$ \\
\hline
\end{tabular}


TABELA 04. (cont.) Síntese de métodos utilizados para a determinação de medida de sucção nos solos (Vilar, 2000)

\begin{tabular}{|c|c|c|c|c|}
\hline MÉTODO & REALIZADO & TIPO DE SUCÇÃO & $\begin{array}{c}\text { FAIXA DE MEDIDA } \\
(\mathrm{kPa})\end{array}$ & OBSERVAÇÃO \\
\hline $\begin{array}{l}\text { Sensores de } \\
\text { condutividade térmica }\end{array}$ & Laboratório & Matricial & 0 a 400 & $\begin{array}{l}\text { - Cápsula cerâmica contendo sensor de temperatura e mini- } \\
\text { aquecedor; } \\
\text { - Condutividade térmica do bloco varia com a sua umidade; } \\
\text { - Equilíbrio solo - cápsula (bloco) > sucção matricial } \\
\text { medida a partir da condutividade térmica. }\end{array}$ \\
\hline $\begin{array}{l}\text { Extrato da solução do } \\
\text { solo }\end{array}$ & Laboratório & Osmótica & Todos os valores & $\begin{array}{l}\text { - Condutividade do extrato; } \\
\text { - Concentração de solutos; } \\
\text { - Extrato e psicrômetro (resolução não satisfatória). }\end{array}$ \\
\hline Princípios osmóticos & Laboratório & Matricial & $\begin{array}{c}200 \text { a } 1600 \\
\text { (PEG 20.000) }\end{array}$ & $\begin{array}{l}\text { Membrana de celulose para diálise; } \\
\text { - Solução com concentração conhecida e umidade relativa } \\
\text { conhecida; } \\
\text { - Solução de PoliEtileno Glicol (PEG), peso molecular } \\
20.000 ; \\
\text { - Útil para instalar e controlar sucção em ensaios. }\end{array}$ \\
\hline $\begin{array}{l}\text { Equilíbrio da fase de } \\
\text { vapor }\end{array}$ & Laboratório & Total & Toda a faixa acima de $\cong 400$ & $\begin{array}{l}\text { - Solução com concentração e umidade relativa conhecida; } \\
\text { - Amostra de solo em dessecador sem contato com a } \\
\text { solução; } \\
\text { - Equilíbrio demorado. }\end{array}$ \\
\hline
\end{tabular}




\subsubsection{Placa de Sucção}

Este método consiste de duas câmaras, uma de ar e outra de água, separadas por uma pedra porosa. A pressão no ar é mantida constante e igual a atmosférica e a sucção é aplicada diminuindo-se a pressão (negativa) na água. Esta técnica apresenta limitações na sua aplicabilidade, devido à ocorrência de cavitação no reservatório de água ( $\mathrm{p}_{\text {suc }}$ máx. $=100 \mathrm{kPa}$ ou $1 \mathrm{~atm}$ ) e à pressão de borbulhamento da pedra porosa, que é a pressão de sucção a partir da qual o ar consegue fluir através da pedra porosa, o que torna inviável a manutenção da pressão negativa na água (Wolle e Carvalho, 1988). Portanto, esta técnica pode ser utilizada para baixas sucções.

\subsubsection{Câmara de Pressão com placa porosa de alta pressão de entrada de ar ou de Richards}

A câmara de pressão é um equipamento utilizado para a elaboração de curvas características de retenção de água no solo ou seja, determinação da umidade versus potencial matricial sob condições de laboratório (Libardi, 1995).

O equipamento consiste basicamente de uma câmara (Figura 20), hermeticamente fechada, construída para suportar altas pressões, com uma placa porosa de alta pressão de entrada de ar em seu interior, com vazios bastante diminutos, que permitem, dentro de certos limites, o fluxo de água, porém não o de ar. Estas placas, denominadas de placas de alta pressão de entrada de ar são o elemento chave para o controle da sucção neste equipamento. O limite de trabalho é dado pela pressão de entrada de ar, que é a pressão capaz de dar início ao fluxo de ar através da placa e que pode atingir até 15 bar. Acima dessas sucções, pode-se utilizar as membranas de celulose como elemento de interface para controle de sucção no lugar da placa porosa, onde há a possibilidade de medir valores de sucção de até $10.000 \mathrm{kPa}$. 


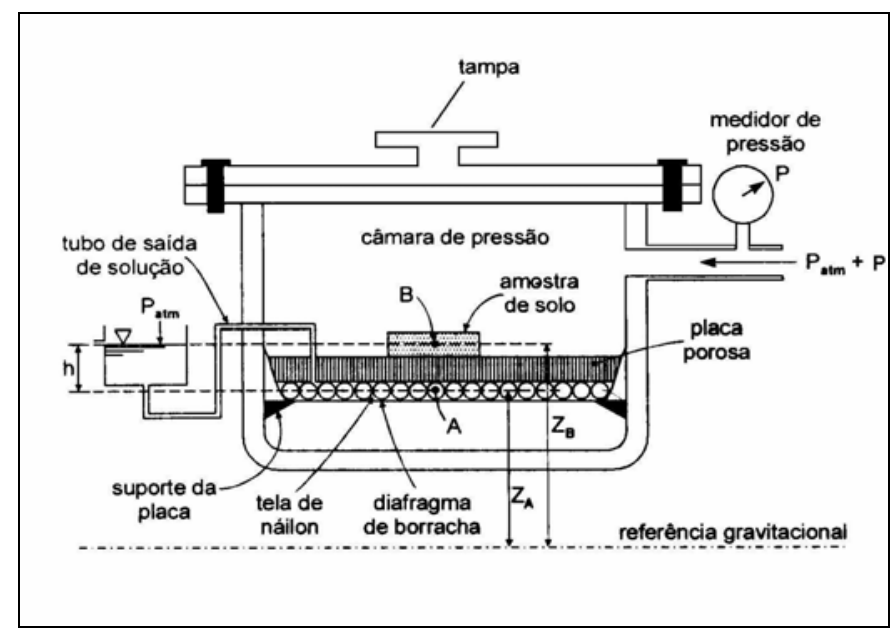

FIGURA 20. Câmara de pressão de Richards (Libardi, 1995).

A realização do ensaio pelo processo de secagem, consiste basicamente na utilização de uma ou mais amostras de solo que são colocadas na superfície da placa de cerâmica, que deverá ser saturada em água destilada, da mesma forma que as amostras que irão ser utilizadas. Esta saturação em ambas (placa e amostras) deverá ser realizada por um período de 24 horas. Em seguida, o conjunto é colocado no interior da câmara e são aplicadas pressões sucessivas de ar. Assim, a sucção induzida é transmitida ao solo, alcançando-se um equilíbrio depois da eliminação parcial da água em cada estágio. Em cada estágio o corpo de prova é pesado para determinação da sua umidade, na condição final de equilíbrio, a pressão de ar aplicado é igual à sucção do solo.

Com os dados de sucção e de umidade respectivamente para cada estágio pode-se obter a curva de retenção do solo. Assim, a sucção matricial corresponde à pressão de ar imposta em cada estágio, visto que a pressão na água é a atmosférica.

Com os dados de sucção e de umidade respectivamente para cada estágio pode-se obter a curva de retenção de água do solo (Croney e Coleman, 1960). 


\subsubsection{Tensiômetro}

Este equipamento é composto por um sistema hidráulico fechado com uma cápsula cerâmica permeável a água e sais, ligada a um manômetro contendo água ou mercúrio. Quando se coloca a cápsula porosa em contato com o solo, a pressão atuante na fase líquida do solo é transmitida ao reservatório de água do sistema, onde é detectada pelo medidor de pressão, sendo esta, a sucção do solo.

Sendo que a pressão atuante na fase líquida do solo não saturado é negativa, o limite da medição da sucção matricial pelo tensiômetro é a pressão de cavitação. A partir desta pressão surge o aparecimento de bolhas de ar e descontinuidades, limitando estes aparelhos a pressões da ordem de $70 \mathrm{kPa}$.

As limitações de medida de tensiômetros convencionais têm sido superadas através do uso de tensiômetros de alta capacidade, dos quais se tira proveito da elevada resistência à tração da água (Ridley e Burland, 1993).

\subsection{Tensiômetros de Alta Capacidade}

O tensiômetro de alta capacidade, que permite a obtenção de valores de sucção superiores a $100 \mathrm{kPa}$, sem que ocorra cavitação no sistema foi proposto por Ridley e Burland (1993, 1995).

O princípio do equipamento é semelhante aos dos convencionais, sendo baseado na transmissão da tensão da água numa ponta porosa em equilíbrio com o solo até o sistema de medição de pressão, porém, sucções de até $1.500 \mathrm{kPa}$ são alcançadas devido a alta resistência à tração da água, que é da ordem de $500.000 \mathrm{kPa}$ (Tabor, 1979), e adotando a técnica de pressurissação da água no reservatório que inibe a formação de bolhas de ar no tensiômetro inicialmente usado por Harvey et al., (1994).

\subsubsection{Método do Papel Filtro}

A medida do potencial matricial do solo, a partir do uso do papel filtro foi inicialmente proposta por Gardner (1937), que partiu do pressuposto de que colocando o solo em contato com um material poroso qualquer, capaz de reter umidade, ocorreria migração de água, até estabelecer-se o equilíbrio de potencial. 
De acordo com Marinho (1995), o método baseia-se no princípio de absorção e equilíbrio, ou seja, quando um solo é colocado em contato com um material poroso que possua capacidade de absorver água, a mesma irá passar do solo para o material poroso até que o equilíbrio seja alcançado. Tendo-se a relação entre sucção e umidade do material poroso (calibração), a sucção do solo pode ser obtida referindo-se à curva de calibração. O estado de equilíbrio fornece a mesma sucção no solo e no material poroso, porém, umidades diferentes.

Deve-se tomar cuidado com o tempo de equilíbrio, por ser um fator de extrema importância para a obtenção da sucção correta.

De forma geral, a técnica consiste em colocar um papel filtro com características de retenção conhecidas, numa vasilha hermética junto com uma amostra de solo. Quando se atinge equilíbrio de umidade, torna-se possível determinar a sucção do solo usando-se uma curva de calibração prévia do papel.

A sucção obtida vai depender do tipo de transferência de água do solo para o papel, que pode se dar por capilaridade ou por vapor (Marinho, 1995).

Os tipos de papéis mais usados são o Schleicher \& Shuell $\mathrm{N}^{0} 589$ e o Whatman $\mathrm{N}^{\mathrm{O}}$ 42, que deve ser utilizado diretamente da caixa, ou seja, no estado seco. A norma americana ASTM - D 5298-92 sugere que o papel filtro seja seco em estufa por cerca de 16 horas antes do uso. Este procedimento pode interferir nas características de absorção do papel, alterando a curva de calibração (Marinho, 1994).

O papel filtro Whatman $\mathrm{N}^{\mathrm{o}} 42$ apresenta uma umidade inicial no estado seco de cerca de 6\%, permitindo medições de sucção de zero até $29 \mathrm{MPa}$, que é a sucção máxima que o solo pode ter para que o papel filtro absorva a água do mesmo (Marinho, 1995).

Para a calibração do papel filtro podem ser utilizadas várias técnicas, sendo que as principais estão mostradas na Tabela 05 . O procedimento é realizado, permitindo que o papel filtro atinja o estado de equilíbrio a partir de uma sucção conhecida. A seguir é pesado e seco em estufa (duas horas de secagem a $105^{\circ} \mathrm{C}$ ). Após a secagem, a umidade obtida é relacionada com a sucção gerada. A escolha do método para a geração da sucção vai depender do nível de sucção desejado. 
TABELA 05. Técnicas mais usadas para calibração do papel filtro (Marinho, 1995)

\begin{tabular}{|c|c|c|}
\hline TÉCNICA & $\begin{array}{c}\text { FAIXA DE SUCÇÃO PARA A } \\
\text { CALIBRAÇÃO DO PAPEL FILTRO }\end{array}$ & COMENTÁRIOS \\
\hline Placa de sucção & 0 a $1 \mathrm{~atm}$ & Sucção gerada diretamente. \\
\hline Amostras de campo & 0 a $2 \mathrm{Mpa}$ & $\begin{array}{l}\text { Utiliza a habilidade dos solos } \\
\text { plásticos de sustentar a média } \\
\text { de tensão efetiva quando } \\
\text { descarregado sob condição } \\
\text { não drenada. Assume-se que a } \\
\text { sucção matricial é } \\
\text { numericamente igual a média } \\
\text { da tensão efetiva da amostra } \\
\text { no campo. }\end{array}$ \\
\hline Amostras edométricas & $0.1 \mathrm{Mpa}$ a $2 \mathrm{Mpa}$ & $\begin{array}{l}\text { Assume descarregamento } \\
\text { unidimensional e não drenado. } \\
\text { A pressão de consolidação } \\
\text { aplicada é numericamente } \\
\text { igual a sucção matricial da } \\
\text { amostra descarregada. }\end{array}$ \\
\hline Placa de pressão & 0 a $1.5 \mathrm{MPa}$ & $\begin{array}{l}\text { Usa a técnica de translação de } \\
\text { eixos. }\end{array}$ \\
\hline Dessecador & $0.5 \mathrm{MPa}$ a $30 \mathrm{MPa}$ & $\begin{array}{l}\text { Soluções com a pressão de } \\
\text { vapor conhecida são } \\
\text { utilizadas. O papel filtro é } \\
\text { colocado em ambiente } \\
\text { fechado com a solução. A } \\
\text { transferência de água é por } \\
\text { vapor. O equilíbrio é } \\
\text { alcançado quando a afinidade } \\
\text { por água da solução usada e } \\
\text { do papel filtro são } \\
\text { equalizadas. }\end{array}$ \\
\hline
\end{tabular}

$\mathrm{Na}$ Tabela 06 estão apresentadas algumas correlações obtidas para a determinação da pressão de sucção (expressos em cm de água) em função da umidade de equilíbrio do papel. 
TABELA 06. Correlações para determinação da sucção com o método do papel filtro (Vilar, 1997)

\begin{tabular}{|c|c|c|c|}
\hline Autor & Tipo de papel & Correlação & Observação \\
\hline $\begin{array}{l}\text { Fawcett \& Collis- } \\
\text { George (1967) }\end{array}$ & Whatman $\mathrm{N}^{\circ} 42$ & $\mathrm{pF}=5,777-0,060 \mathrm{w}$ & $\mathrm{pF}$ entre 2,6 e 4,5 \\
\hline $\begin{array}{ll}\text { McQueen } \quad \& \\
\text { Miller (1968) }\end{array}$ & $\begin{array}{l}\text { Schleider } \quad \& \\
\text { Schull } \mathrm{N}^{\mathrm{o}} 589\end{array}$ & $\mathrm{pF}=6,246-0,0723 \mathrm{w}$ & $\mathrm{pF}$ entre 2,3 e 5,9 \\
\hline Hamblin (1981) & Whatman $\mathrm{N}^{\mathrm{o}} 42$ & $\mathrm{pF}=6,281-0,0822 \mathrm{w}$ & \\
\hline $\begin{array}{l}\text { Chandler \& } \\
\text { Gutierrez (1986) }\end{array}$ & Whatman $\mathrm{N}^{\circ} 42$ & $\mathrm{pF}=5,850-0,062 \mathrm{w}$ & $\begin{array}{l}\mathrm{pF} \text { entre } 2,9 \text { e } 4,8 \\
\text { w entre } 17 \% \text { e } 47 \% \\
\text { sucção entre } 80 \text { e } 600 \mathrm{kPa}\end{array}$ \\
\hline $\begin{array}{l}\text { Chandler et al. } \\
\text { (1992) }\end{array}$ & Whatman $\mathrm{N}^{\mathrm{o}} 42$ & $\begin{array}{l}\mathrm{w}>47 \%-\text { sucção } \\
(\mathrm{kPa})=10^{(6.05-2.48 \log \mathrm{w})} \\
\mathrm{w} \leq 47 \%-\text { sucção } \\
(\mathrm{kPa})=10^{(4.84 .-0.0622 \mathrm{w})}\end{array}$ & \\
\hline ASTM D5298 & Whatman $\mathrm{N}^{\circ} 42$ & $\begin{array}{l}\mathrm{pF}=6,327-0,0779 w \\
\mathrm{pF}=3,412-0,0135 w\end{array}$ & $\begin{array}{l}\mathrm{w} \leq 54 \% \\
\mathrm{w}>54 \% \\
\mathrm{pF}>2,1 \\
\text { sucção }>50 \mathrm{kPa}\end{array}$ \\
\hline
\end{tabular}

Onde: pF: Logaritmo da pressão expresso em centímetros de água e w: Umidade do papel (\%).

No caso do método do papel filtro, a determinação do fluxo de água pode ocorrer de duas maneiras: por fluxo de vapor ou por fluxo capilar.

A Figura 21, esquematiza os dois tipos de fluxo para o papel filtro (Marinho, 1995). 


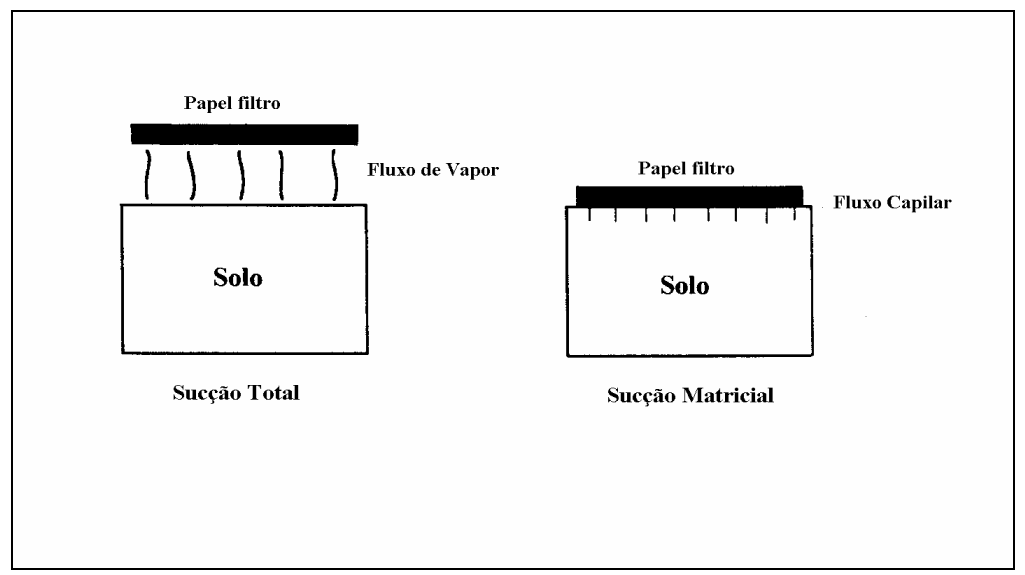

FIGURA 21. Tipos de fluxo do solo para o papel filtro (Marinho, 1995).

A medição da sucção matricial é realizada quando o fluxo ocorre apenas por capilaridade e o ensaio é realizado através do contato direto através das partículas do solo e das fibras do papel filtro, sem que a água perca continuidade, implicando interação entre o papel filtro e a água do poro, isto é, com sais, etc.

Quando a sucção é medida através do fluxo de vapor, as moléculas de água têm que sair da água dos poros vencendo as forças de capilaridade do solo e eventualmente as forças osmóticas que agem devido à presença de sais. O espaço deixado entre o papel filtro e o solo age como uma barreira para os sais, permitindo que ocorra apenas o fluxo por vapor de água (água pura) e a medição feita é a sucção total.

Segundo Fredlund e Rahardjo (1993), o tempo de resposta do papel é da ordem de no mínimo uma semana. A técnica requer manuseio delicado do papel e precisão da pesagem (da ordem de $0.001 \mathrm{~g}$ ).

$\mathrm{Na}$ Tabela 07, pode-se observar algumas sugestões para o tempo de equilíbrio para a medição da sucção total em função do nível de sucção desejada para o papel filtro Whatman $\mathrm{N}^{\circ} 42$.

TABELA 07. Sugestão para o tempo de equilíbrio para a medição da sucção total em função do nível de sucção (Marinho, 1995)

\begin{tabular}{|c|c|}
\hline Nível de Sucção Total $(\mathrm{kPa})$ & Tempo de equilíbrio sugerido \\
\hline 0 a 10 & Não determinado, certamente superior a 30 dias \\
\hline 100 a 250 & 30 dias \\
\hline 250 a 1000 & 15 dias \\
\hline $1000-3000$ & 7 dias \\
\hline
\end{tabular}


A técnica do papel filtro é simples, mas requer extremo cuidado na determinação do teor de umidade do papel, devido a evaporação que pode ocorrer até que sejam realizadas as pesagens.

\subsubsection{Blocos Porosos}

Segundo Richards (1974), neste método, um bloco poroso composto por dois eletrodos e para o qual a relação entre a umidade e a eletroresistividade é conhecida através da curva de calibração, é inserido no solo. Após estar instalado, o bloco atinge uma umidade correspondente ao equilíbrio de pressões de sucção, que pode ser detectada através da resistividade elétrica entre os eletrodos.

O material do bloco é escolhido em função da sucção interesse e de sua resistência ao desgaste físico e químico. Este método apresenta como principais desvantagens o longo tempo de resposta (dias), deterioração do material, histerese na relação umidade versus sucção do bloco e possíveis variações na curva de calibração. É mais indicado para uso em laboratório, onde persistem condições essencialmente constantes de sucção.

\subsubsection{Psicrômetros}

São aparelhos que servem para medir a sucção total do solo através da medição da umidade relativa do ar no solo em equilíbrio com a interface solo-água. Consiste basicamente de uma cápsula porosa em contato com o solo, dotado de um termopar ligado a um microvoltímetro e uma fonte de alimentação elétrica, e um sensor de temperatura.

Os psicrômetros permitem a medição de sucções de 100 até $8000 \mathrm{kPa}$. Segundo Richards (1974), a variação das respostas podem ser de poucas horas até duas semanas dependendo da sucção do solo analisado.

Segundo Wolle e Carvalho (1988), mesmo os psicrômetros mais modernos e sofisticados, não permitem leituras confiáveis em condições de campo, para pressões de sucção inferiores a $50 \mathrm{kPa}$, devido principalmente, às variações de temperatura, que devem ser detectadas com grande precisão. Além disso, nessa faixa de pressão os tempos de resposta são longos (horas). Estes equipamentos são mais indicados para situações de pressão elevadas. 


\subsubsection{Equilíbrio da Fase Vapor}

O ensaio é realizado colocando amostras num dessecador que contêm uma solução aquosa de um dado composto químico. De acordo com as propriedades físicoquímicas deste composto, uma determinada umidade relativa é imposta dentro do dessecador. Mudanças de água ocorrem por transferências de vapor entre a solução e a amostra, e uma determinada sucção é aplicada na amostra quando o equilíbrio de vapor é atingido.

Para a solução aquosa podem ser utilizados diferentes produtos como ácido sulfúrico ou várias soluções salinas com diferentes concentrações. Por facilidade e segurança prefere-se utilizar a solução salina ao ácido sulfúrico. Existem alguns problemas quanto à sensibilidade da umidade relativa com as mudanças de temperatura, bem como às propriedades físicas dos compostos químicos. A temperatura neste ensaio é um aspecto a ser considerado, por que se precisa de um bom controle durante a fase de equilíbrio. Por essa razão, o dessecador deve ser mantido numa temperatura controlada de $20^{\circ} \mathrm{C} \pm 0,1^{\circ} \mathrm{C}$ (Delage et al., 1997).

\subsubsection{Ensaios edométricos sob sucção controlada}

\subsubsection{Edômetro de membrana}

Segundo Aitchison e Martin (1973), este edômetro difere dos convencionais, pelo fato da amostra ser colocada numa câmara de pressão, em contato com uma membrana semipermeável. Na câmara de pressão, introduz-se ar sob pressão e a parte inferior da membrana fica em contato com a água, ou com um líquido eletrolítico à pressão atmosférica. Neste processo, a amostra pode ser sujeita a várias condições de sucção, seja variando a pressão de ar dentro da câmara, seja variando a composição do eletrólito. 


\subsubsection{Edômetro com controle de sucção de Escario}

Sendo a tensão intersticial nos solos expansivos negativa, em relação à pressão atmosférica, as tensões de expansão devem ser medidas sob controle das condições de sucção e tensões totais existentes nos terrenos.

Escario (1969), apresenta um equipamento que permite medir tensões de expansão sob controle da sucção até valores da ordem de $100 \mathrm{Kg} / \mathrm{cm}^{2}$.

O equipamento consiste basicamente numa célula composta de uma placa porosa de alto valor de entrada de ar (junto com uma membrana semipermeável para sucções acima de 1.500 até $10.000 \mathrm{kPa}$ ) e de um pistão vertical através do qual é possível a aplicação das tensões normais, bem como, a medição das mudanças de volume da amostra

O ensaio quando realizado pelo processo de secagem, consiste na colocação de um corpo de prova equivalente ao do edômetro convencional em contato direto com uma placa porosa, sendo que tanto o corpo de prova como a placa, no início encontramse saturadas. Em seguida, para cada estágio de sucção a pressão de ar equivalente à sucção desejada é imposta dentro da câmara, assim, depois da eliminação parcial de água da amostra através da placa porosa é atingido um equilíbrio de sucção no solo. As variações de umidade em cada estágio de sucção são registradas pela medida de volume de água expulsa numa bureta graduada. Quanto a aplicação das tensões verticais, são similares às utilizadas num edômetro convencional.

Vilar (1994), realizou ensaios para avaliar as deformações provocadas pelo umedecimento de um solo argiloso com características expansivas, compactado com baixa densidade $\left(1,23 \mathrm{~g} / \mathrm{cm}^{3}\right)$ e baixa umidade $(22 \%)$. O efeito umedecimento gradual da amostra foi medido em ensaios com sucção controlada, utilizando o edômetro descrito acima, sendo que as deformações mais significativas ocorreram para sucções inferiores a $500 \mathrm{kPa}$ e máximas quando a sucção foi reduzida a zero.

Pejon (2000), utilizou este equipamento para medir a expansão sob sucção controlada de uma amostra de rocha sedimentar argilosa da Formação Corumbataí. O ensaio foi realizado inicialmente pelo processo de umedecimento, com a aplicação de uma pressão de $800 \mathrm{kPa}$. Durante a fase de equilíbrio da sucção foi monitorada a deformação da amostra, que sofreu uma contração de $1,75 \%$ de altura. Após a estabilização da sucção em $800 \mathrm{kPa}$, a pressão de ar foi sendo reduzida em estágios, de $600,400,200,100$ e $50 \mathrm{kPa}$, e finalmente, a pressão atmosférica. A medida que a 
sucção foi sendo reduzida, ocorreu expansão da amostra, embora a variação total da deformação $(1,61 \%)$, tenha sido inferior a contração experimentada pela amostra quando da aplicação de $800 \mathrm{kPa}$. Em seguida, na mesma amostra, os estágios de pressão foram retomados, pelo processo de secagem, até atingir novamente a pressão de $800 \mathrm{kPa}$. O autor observou que a expansão provocou uma deformação permanente na amostra, uma vez que, quando as pressões de ar foram elevadas novamente até $800 \mathrm{kPa}$, a altura do corpo de prova não retornou a sua altura original.

Os resultados de expansão controlada foram bastante inferiores em relação aos de expansão livre e sem controle de sucção para o mesmo material (10 a 12\%), permitindo ao autor concluir da importância de estudos com sucção controlada para determinação de variações volumétricas de solos e rochas de maneira mais realista.

\subsubsection{Edômetro com membrana osmótica}

Kassif e Ben Shalom (1970, 1971), e posteriormente Kassif et al. (1973), desenvolveram uma célula edométrica que permite o controle de sucção matricial do solo utilizando o princípio osmótico. Zur, 1966; Peck e Rabbidge, 1966). Delage, Vicol e Suraj de Silva (1992); Dineen e Burland (1995), realizaram algumas modificações no equipamento.

Delage, Vicol e Suraj de Silva (1992) desenvolveram um edômetro baseado na técnica osmótica semelhante ao de Kassif e Ben Shalom (1970).

O equipamento consiste numa célula contendo tanto no topo como na base duas membranas semipermeáveis que encontram-se em contato direto com as superfícies da amostra. Adicionalmente, a célula é dotada de dutos no topo e na base que permitem o fluxo da solução nas faces das membranas opostas a amostra. O fluxo da solução garante uma circulação constante a partir de um circuito fechado composto pela base e pistão da célula, reservatório e uma bomba. Através do topo da célula é possível a aplicação das tensões normais, assim como, realizar medidas de deformação da amostra.

O corpo de prova é confinado lateralmente pelo anel porta amostra e colocado em contato direto com uma membrana semipermeável de celulose com diâmetro de poros ou peso molecular cut-off (MWCO) compatível ao peso molecular do PEG utilizado. O valor da sucção matricial desejada é imposta em função da concentração da solução PEG utilizada, sendo que, para uma maior concentração, maior será a sucção matricial. Uma vez colocada a solução em contato com o solo através da membrana, ocorre fluxo 
de água em direção do solo para a solução ou vice-versa (dependendo do nível de energia da água) que cessa quando o equilíbrio osmótico é atingido. As variações de umidade em cada estágio de sucção são registradas pela medida de volume da solução numa bureta graduada. A aplicação das tensões verticais são similares às utilizadas no edômetro convencional.

Kassif e Ben Shalom (1971), desenvolveram um edômetro baseado na técnica osmótica com a finalidade de avaliar a relação entre o potencial expansivo e a sucção matricial.

Estes autores realizaram testes edométricos com mudança de sucção sob tensão vertical constante cujos resultados apresentam-se como a sucção matricial versus porcentagem de expansão em amostras compactadas. Os valores de porcentagem de expansão correspondem à máxima deformação atingida para cada sucção matricial imposta e testes edométricos com mudança de tenção vertical a volume constante para cada sucção imposta cujos resultados são representados pelo potencial de expansão versus sucção matricial. A pressão de expansão corresponde à máxima tensão vertical atingida em cada sucção imposta. Para estes testes utilizaram amostras de solos argilosos expansivos, com alta plasticidade ( $\mathrm{IP}=58$ a $63 \%$ ) e porcentagem da fração argila de 51 a 55\%. Os resultados mostraram que ocorre uma diminuição da porcentagem de expansão e pressão de expansão com o aumento da sucção matricial. As maiores variações tanto de deformação como de pressão de expansão ocorreram entre 100 e 200 kPa de sucção. Segundo Kassif e Ben Shalom (1971), as porcentagens de expansão máximas (quando a sucção matricial igual a zero) depende principalmente da densidade seca do solo. Quanto à pressão de expansão, isto não ocorre com a mesma intensidade, podendo-se encontrar valores similares de pressão de expansão para diferentes densidades secas compactadas com igual teor de umidade inicial. $\mathrm{O}$ teor de umidade e a densidade seca inicial da amostra influenciam na porcentagem de expansão e pressão de expansão. O potencial expansivo aumenta para densidades secas crescentes e teores de umidade iniciais decrescentes. 


\subsubsection{Ensaios edométricos utilizando a técnica de controle de sucção por imposição da umidade relativa}

Esteban e Sáez (1988), adaptaram a técnica a um edômetro para a realização de ensaios de deformabilidade de solos e rochas. A importância da adaptação desta técnica num edômetro consiste na possibilidade do estudo deformacional dos solos não saturados numa faixa de sucção muito alta.

O edômetro é constituído por uma câmara hermética, na qual uma amostra é confinada lateralmente e verticalmente por um anel de aço e pedras porosas de granulação grosseira, de modo que a atmosfera de vapor criada na câmara possa alcançar os poros da amostra. Adicionalmente, possui um depósito destinado às soluções para implementação da umidade relativa e de um pistão que torna possível a medição da deformabilidade da amostra e aplicação das tensões verticais.

O ensaio consiste na colocação de uma amostra em contato com uma atmosfera de umidade relativa controlada mediante uma solução que proporciona a pressão de vapor determinada, tal como se realiza num dessecador de vazios. A relação entre a sucção total e a umidade relativa é dada a partir da equação da energia livre e a variação da sucção do solo dependerá da concentração da solução, elaborada a partir de sais ou ácidos.

Com o objetivo de testar o equipamento, os autores acima, analisaram a relação entre a deformação e sucção de materiais rochosos (margas), utilizando amostras compactadas com uma densidade seca de $2,2 \mathrm{Kg} / \mathrm{cm}^{2}$ e uma umidade inicial de $8 \%$. Os ensaios foram realizados em quatro estágios, para quatro diferentes valores de sucção impostas às amostras $(65,25,12,5$ e $0 \mathrm{MPa})$. Esteban e Sáez (1988), obtiveram a relação entre porcentagem de expansão e tempo em função dos valores das sucções de equilíbrio. O teste foi realizado em cerca de 120 dias. Puderam observar que o processo deformacional ocorreu em duas diferentes fases, cerca de 3\% até a sucção de $12,5 \mathrm{kPa}$ e cerca de $10 \%$ até que a sucção fosse reduzida a 0 , que foi uma deformação mais significativa, se comparada ao valor total ( $3 \%$ versus $13 \%)$.

Mazo, Aunõn e Esteban (1996), realizaram modificações no edômetro descrito acima, com o objetivo de estudar a expansão de materiais argilosos sob sucção controlada e carga vertical variável, mas com medição simultânea da pressão lateral causada pela expansão. Para isto, utilizaram um strain gage dentro da câmara. 
A técnica de controle de sucção por imposição da umidade relativa pode apresentar algumas vantagens e desvantagens, que serão mostradas a seguir:

Vantagens da técnica:

a) Possibilita a medição de altos valores de sucção, acima de 300MPa (Mazo, Auñon e Esteban (1996));

b) As sucções podem ser impostas às amostras a partir de soluções salinas saturadas e aquosas, que são de fácil manuseio e disponíveis no mercado;

c) As pedras porosas de granulação grosseira, utilizadas no equipamento, podem facilmente ser fabricadas no laboratório;

d) É uma técnica considerada padrão para a determinação da sucção total, sendo utilizada na calibração de equipamentos baseados em outros métodos de medição.

Desvantagens da técnica:

a) O tempo de equilíbrio é demorado, aumentando à medida que se pretende impor ao solo sucções mais baixas;

b) Necessita de controle de temperatura, pois a sucção varia com as mudanças desta. 


\section{CAPÍTULO 3. CARACTERÍSTICAS DA ÁREA}

\subsection{LOCALIZAÇÃO DA ÁREA}

A área onde foram obtidas as amostras situa-se a nordeste do Município de Curitiba, abrangendo parte dos municípios de Colombo, Quatro Barras e Campina Grande do Sul, que integram a Região Metropolitana de Curitiba no Paraná, região sul do Brasil (Figura 22).

A área selecionada abrange parte das folhas topográficas A 104 e A 107 (COMEC, 1976), na escala 1: 20.000, possuindo cerca de $117 \mathrm{Km}^{2}$ (latitude sul

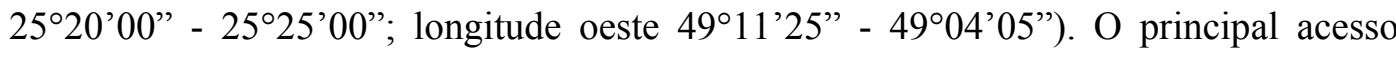
pode ser realizado através da rodovia federal BR 116, que a atravessa no sentido sudoeste - nordeste.

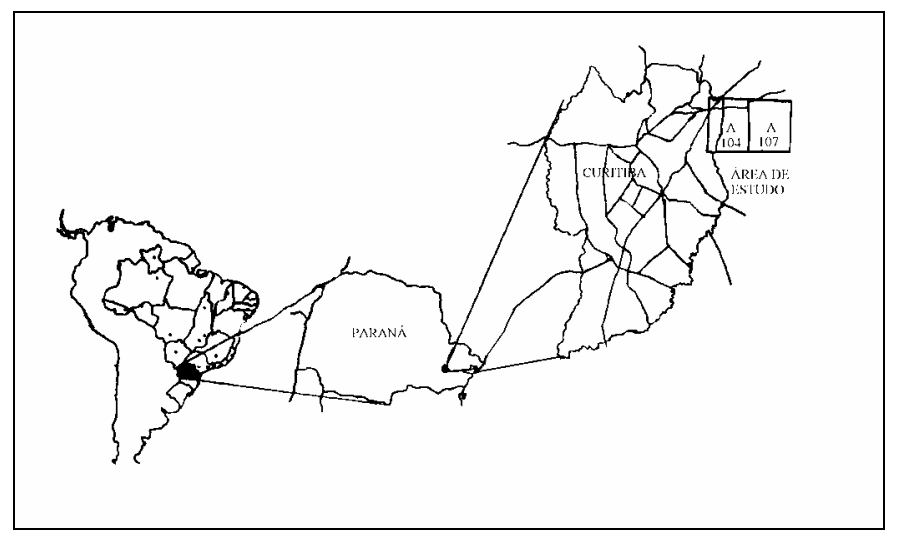

FIGURA 22. Mapa de localização da área de estudo.

Os principais canais de drenagem que cortam a área são os rios Iraí, Timbú e Palmital e seus afluentes. 
De acordo com dados metereológicos obtidos por Hach-Hach (1998), o clima da região estudada varia de quente a temperado, com inverno seco e precipitações anual que variam entre $1103-2116 \mathrm{~mm}$, ocorrendo as maiores pluviosidades nos meses de dezembro, janeiro e fevereiro. As temperaturas máximas situam-se num intervalo entre $18^{\circ} \mathrm{C}$ a $30^{\circ} \mathrm{C}$ no mês de janeiro e a mínima em cerca de $3^{\circ} \mathrm{C}$ no mês de julho, sendo que nos demais meses do ano, as temperaturas máximas variam entre $17^{\circ} \mathrm{C}-22^{\circ} \mathrm{C}$ e as mínimas entre $3^{\circ} \mathrm{C}-12^{\circ} \mathrm{C}$.

\subsection{CARACTERIZAÇÃO GEOLÓGICA}

\subsubsection{Considerações Gerais}

A Bacia Sedimentar de Curitiba situa-se na porção centro - sul do Primeiro Planalto Paranaense, perfazendo uma área de cerca de $3.000 \mathrm{Km}^{2}$, e está enquadrada entre os paralelos $25^{\circ} 15^{\prime} 00^{\prime}$ e e $25^{\circ} 55^{\prime} 00^{\prime \prime}$ de latitude sul e entre os meridianos 4900'00" e 49 35'00" de longitude oeste, abrangendo Curitiba (PR) e municípios vizinhos, que constituem a Região Metropolitana de Curitiba.

Segundo Bigarella e Salamuni (1962), a bacia de Curitiba foi formada sobre um embasamento de rochas gnáissico-migmatíticas do Complexo Cristalino (Arqueano e Proterozóico Inferior), sob condições de clima variando do semi-árido ao úmido, provavelmente durante o Plio - Pleistoceno, não descartando a ampliação destas idades até o Terciário Médio. Sobre os sedimentos plio - pleistocênicos, acumularam-se depósitos de planícies alúvio - coluvionares (depósitos de várzea do Holoceno). Os primeiros sedimentos receberam a denominação de Formação Guabirotuba.

Segundo Salamuni e Salamuni (1999), o embasamento cristalino é de grande importância na região, tanto do ponto de vista geológico quanto geomorfológico, além de ter sido a fonte primordial dos sedimentos que compreendem as seqüencias sobrepostas.

Salamuni (1998), baseado em características tectônicas e de ocorrências fossilíferas posiciona a sedimentação e o retrabalhamento dos sedimentos da bacia entre o Oligoceno - Mioceno (Formação Guabirotuba) e o Pleistoceno Inferior. 
As litologias presentes na Bacia de Curitiba são produto dos diversos ciclos climáticos e erosivos que atuaram na região durante sua evolução geológica (Bigarella e Salamuni, 1962 e Becker, 1982).

De acordo com Salamuni e Salamuni (1999), em termos hipsométricos, a depressão da Bacia de Curitiba varia de altitude, desde $940 \mathrm{~m}$ até $870 \mathrm{~m}$.

\subsubsection{Formação Guabirotuba}

Os sedimentos da Formação Guabirotuba estão distribuídos desde o município de Campo largo até o município de Quatro Barras, abrangendo Curitiba como um todo e parte dos seis municípios limítrofes (Figura 23).

A Formação Guabirotuba é constituída predominantemente por argilitos e arcósios, além de depósitos rudáceos e pequenos horizontes de caliche (impregnações de carbonato de cálcio), anteriormente interpretados como margas pelos mesmos autores (Bigarella e Salamuni, 1962). Além dos argilitos ocorrem areias arcosiana (20 $40 \%$ de feldspato) e arcósios em camadas descontínuas e lenticulares com espessuras muito variáveis. Podem ser encontrados nas bordas da bacia depósitos de cascalho.

Os argilitos constituem a principal litologia da Formação Guabirotuba. Ocorrem nas colorações cinza esverdeado a esbranquiçado, bem compactados, texturas predominantemente maciças, granulação muito fina, com grãos de areia esparsos em sua

massa (Salamuni e Salamuni, 1999). A composição mineralógica da fração argila é representada predominantemente pelo grupo das esmectitas (Mineropar, 1994). Ocorrem partículas siltosas ou arenosas em proporções variáveis no material, além de freqüentemente ocorrerem grãos de feldspato, por vezes, caulinizados. Quando não alterados, o material apresenta-se bastante consistente, sendo que esta consistência tende a reduzir-se quando as camadas mais superficiais apresentam processos de laterização incipiente ou uma plintificação. As colorações neste caso tornam-se variegadas, amareladas ou avermelhadas. Tais processos lateríticos demonstram mudanças no regime climático durante a evolução da Bacia de Curitiba (Salamuni e Salamuni, 1999). Os argilominerais do grupo da caulinita assumem uma maior parcela na composição do material, ocorrendo também hematita e gibsita (Fortin et al.,1989). 


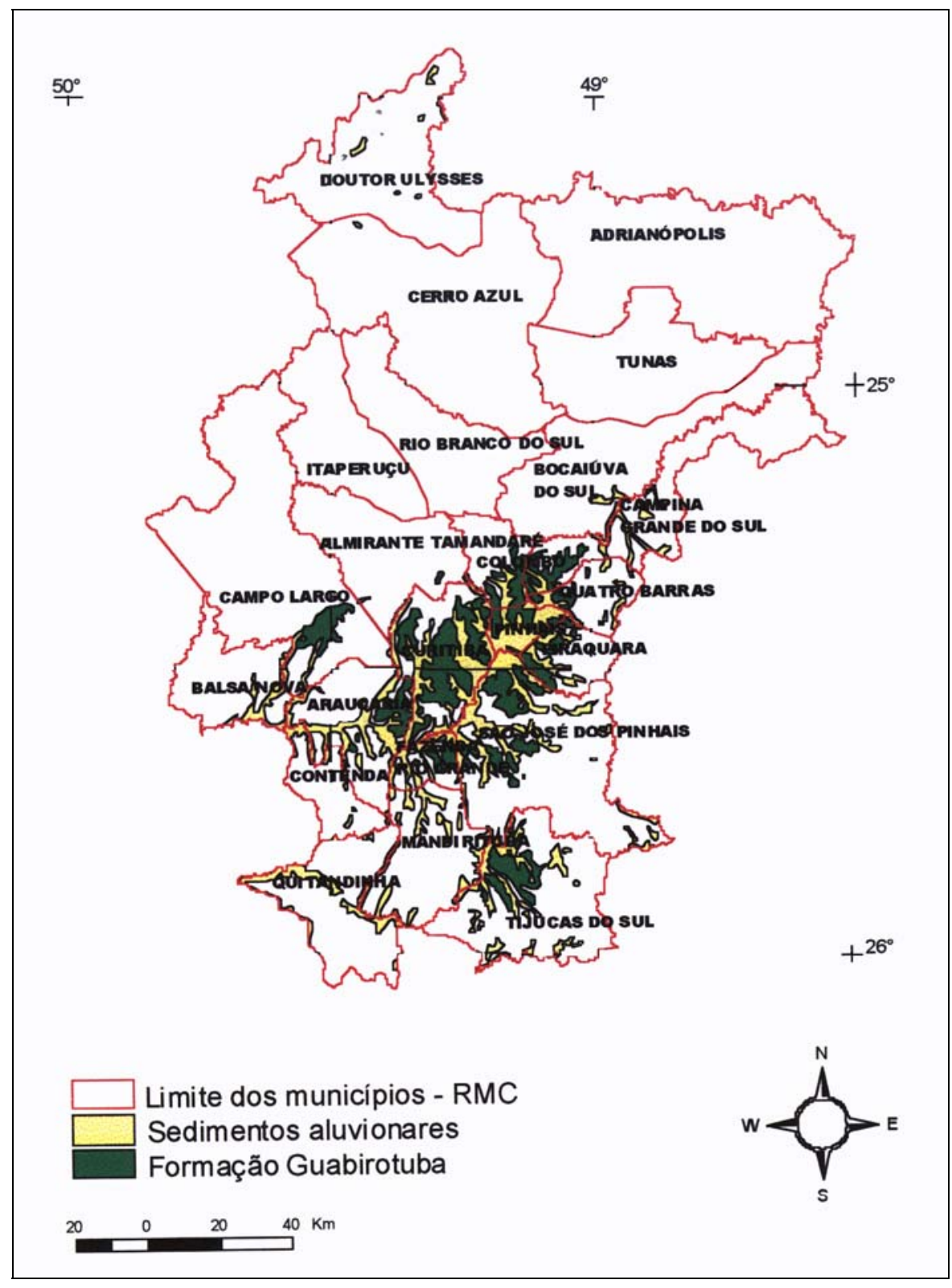

FIGURA 23. Distribuição da Formação Guabirotuba na Região Metropolitana de Curitiba. Fonte: Mapa Geológico do Estado do Paraná, DNPM/Mineropar/1989 (Felipe, 1998).

De acordo com Kormann (2002), os sedimentos argilosos possuem superfícies polidas (slinkensides), que podem ser planas ou conchoidais, sendo que estas feições seguem um padrão de difícil identificação e constituem planos de fraqueza que dividem o material em fragmentos centimétricos a decimétricos. Estas superfícies deixam de ser discerníveis à medida que o intemperismo do material se acentua. 
Os arcósios e areias arcosianas ocorrem em meio aos depósitos argilosos como formas tabulares e lenticulares, em diferentes profundidades (Becker, 1982). Salamuni (1998) identificou uma maior freqüência dessas areias nas áreas situadas entre a porção central e a periferia da bacia. A coloração desses solos pode ser variegada, cinza, avermelhada ou esbranquiçada quando os feldspatos encontram-se alterados. Os pacotes de arcósios apresentam espessuras de até 3,0 metros, sendo que sua extensão pode alcançar grandes áreas (Felipe, 1999). Segundo Salamuni e Salamuni (1999), as areias arcosianas possuem uma espessura bastante irregular.

Os depósitos conglomeráticos ocorrem na base da Formação Guabirotuba, podendo ser observado em afloramentos nas bordas da bacia. Consistem em materiais granulares, com diâmetros variando entre 1 e $50 \mathrm{~mm}$, podendo alcançar até $100 \mathrm{~mm}$, inseridos em uma matriz argilosa. A proporção aproximada de material grosseiro em relação à matriz é de $50 \%$ (Felipe, 1999).

De acordo com Salamuni (1998), os depósitos carbonáticos (caliches) aparecem mais superficialmente, em camadas com poucos metros de espessura. Os caliches possuem a peculiaridade de estarem associados a minerais do grupo das terras raras, tais como lantanita, neodímio, praseodímio, gadolíneo, samário e európio.

Becker (1982), propôs a subdivisão da Formação Guabirotuba em duas unidades distintas, a partir de observações em campo de inconformidades erosivas dentro desta, reconhecendo uma nova seqüência sedimentar denominada de Formação Tinguis. A unidade inferior subjacente à Formação Tinguis corresponderia à Formação Guabirotuba e seria composta por areias arcosianas e argilitos cinza-esverdeado. As camadas avermelhadas da porção superior que anteriormente eram considerados como produto do intemperismo da Formação Guabirotuba, constituiria uma seqüência sedimentar depositada durante épocas de semi-aridez, sendo composta por sedimentos arenosos, arcosianos e síltico-argilosos da própria Formação Guabirotuba, retrabalhados em clima semi-árido, sendo englobadas na Formação Tinguis. Assim, a coloração cinzaesverdeada caracterizaria a unidade inferior e a avermelhada seria típica da unidade superior.

Conforme a mesma autora, grande parte dos sedimentos que constituem a Formação Guabirotuba foram originadas a partir da decomposição química das rochas pré-cambrianas em clima úmido, porém transportados e depositados em condições semi-áridas. 
De acordo com dados geológicos gerados pela Mineropar (1994), que realizou um Mapeamento Geológico-Geotécnico na região do Alto Iguaçu, na escala 1:20.000, a Formação Guabirotuba pode ser subdividida nesta região em duas subunidades, sendo a primeira constituída por sedimentos argilosos de cor cinza-esverdeado com freqüentes intercalações de arcósio, encontrada em níveis topográficos mais elevados e a segunda, composta por sedimentos argilosos de cor cinza a cinza-esverdeado, com porcentagem variável de grânulos de quartzo e feldspato, com raras ocorrências de arcósio, normalmente relacionada a níveis topográficos menos elevados.

De acordo com Felipe (1999), o perfil típico de alteração da Formação Guabirotuba, pode ser estabelecido como mostrado na Figura 24, onde:

a) Solo transportado (colúvio) argilo-arenoso, laterítico, poroso, marrom escuro a negro, espessura centimétrica a métrica, baixa resistência à penetração;

b) Linha de seixos de quartzo sub-angulosos com espessuras centimétrica a métrica;

c) Solo maduro, vermelho, homogêneo, textura argilosa a muito argilosa, argilomineral predominante é a caulinita, espessuras variando de 0,5 a 5,0 $\mathrm{m}$;

d) Argilas alteradas, saprólito, de cor variegada, vermelha, roxa, amarela, contendo por vezes grãos de quartzo e feldspato alterados (caulim), textura argilosa, permeabilidade de $10^{-5} \mathrm{~cm} / \mathrm{s}$. O argilomineral predominante é do grupo da esmectita. As espessuras variam de 1,0 a mais de 5,0m, resistência à penetração é média à rija. São caracterizadas pela expansividade, empastilhamento e trincas provenientes da retração;

e) Argila de cor cinza esverdeada, com grãos de quartzo e feldspato alterado (caulim), textura argilosa a muito argilosa. $\mathrm{O}$ argilomineral predominante é do grupo da esmectita, apresenta permeabilidade de $10^{-5} \mathrm{~cm} / \mathrm{s}$, espessuras muito variáveis de 1,0 a mais de $5,0 \mathrm{~m}$, resistência à penetração gradual de média à rija, por vezes muito rija. São características desta argila a expansividade, empastilhamento e trincas profundas, em forma conchoidal, resultantes da retração;

f) Arcósios: são corpos lenticulares, são compostos por quartzo e feldspato, granulometria fina à grossa, ocorrem de maneira dispersa e em diferentes profundidades, com espessuras de até 3,0m; 
g) Arcósios e cascalhos: ocorrem na base da formação Guabirotuba, normalmente no contato com os saprolitos dos gnaisses-migmatitos.

Segundo o mesmo autor, as argilas alteradas e cinza esverdeadas da Formação Guabirotuba são expansivas, retrativas e higroscópicas.

A Formação Guabirotuba é a principal unidade sedimentar da bacia de Curitiba. Apresenta espessuras irregulares, variando desde 1 metro até um máximo de 80 metros, sendo que nas porções central e centro-sudeste estão localizadas as maiores espessuras e as menores nas bordas da bacia. A espessura média é de aproximadamente 40 metros (Salamuni e Salamuni, 1999).

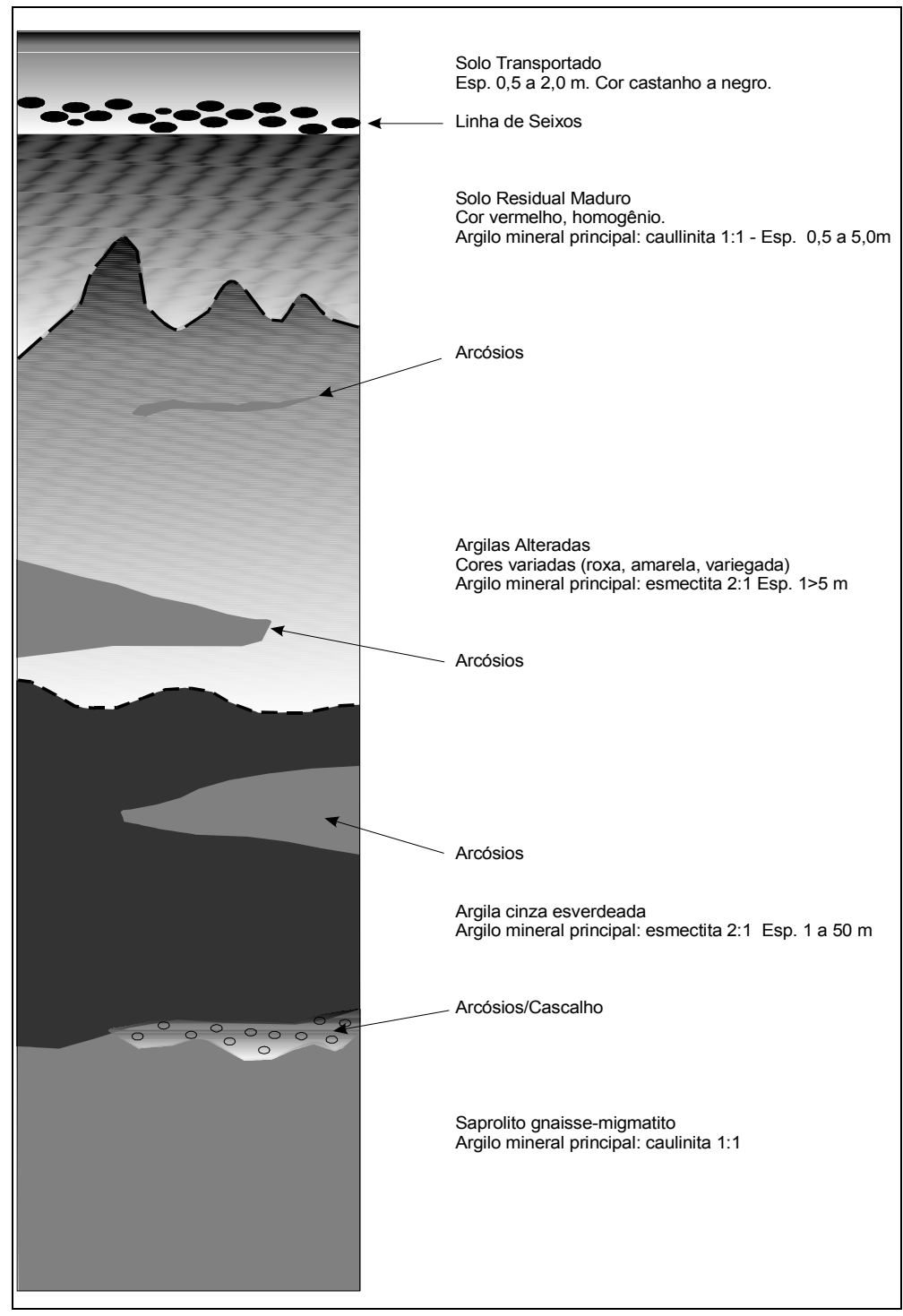

FIGURA 24. Perfil típico de alteração da Formação Guabirotuba (Felipe, 1999). 


\section{CAPÍTULO 4. MATERIAIS E MÉTODOS}

\subsection{MATERIAIS}

\subsubsection{Materiais argilosos analisados}

Os materiais sedimentares argilosos da Formação Guabirotuba analisados no presente trabalho foram coletados em cinco locais distintos, que estão representados no Mapa Geológico da Figura 25, sendo o material 1 no Município de Curitiba, os materiais 2 e 3 no Município de Colombo, o material 4 no Município de Pinhais e o material 5 no Município de Campina Grande do Sul, todos no estado do Paraná.

De acordo com o perfil típico de alteração da Formação Guabirotuba, mostrado na Figura 24 (Felipe, 1999), os materiais sedimentares 1, 2, e 3 estão inseridos no item "d" (argilas alteradas) e os materiais 4 e 5 no item "e" (argila cinza esverdeada). 


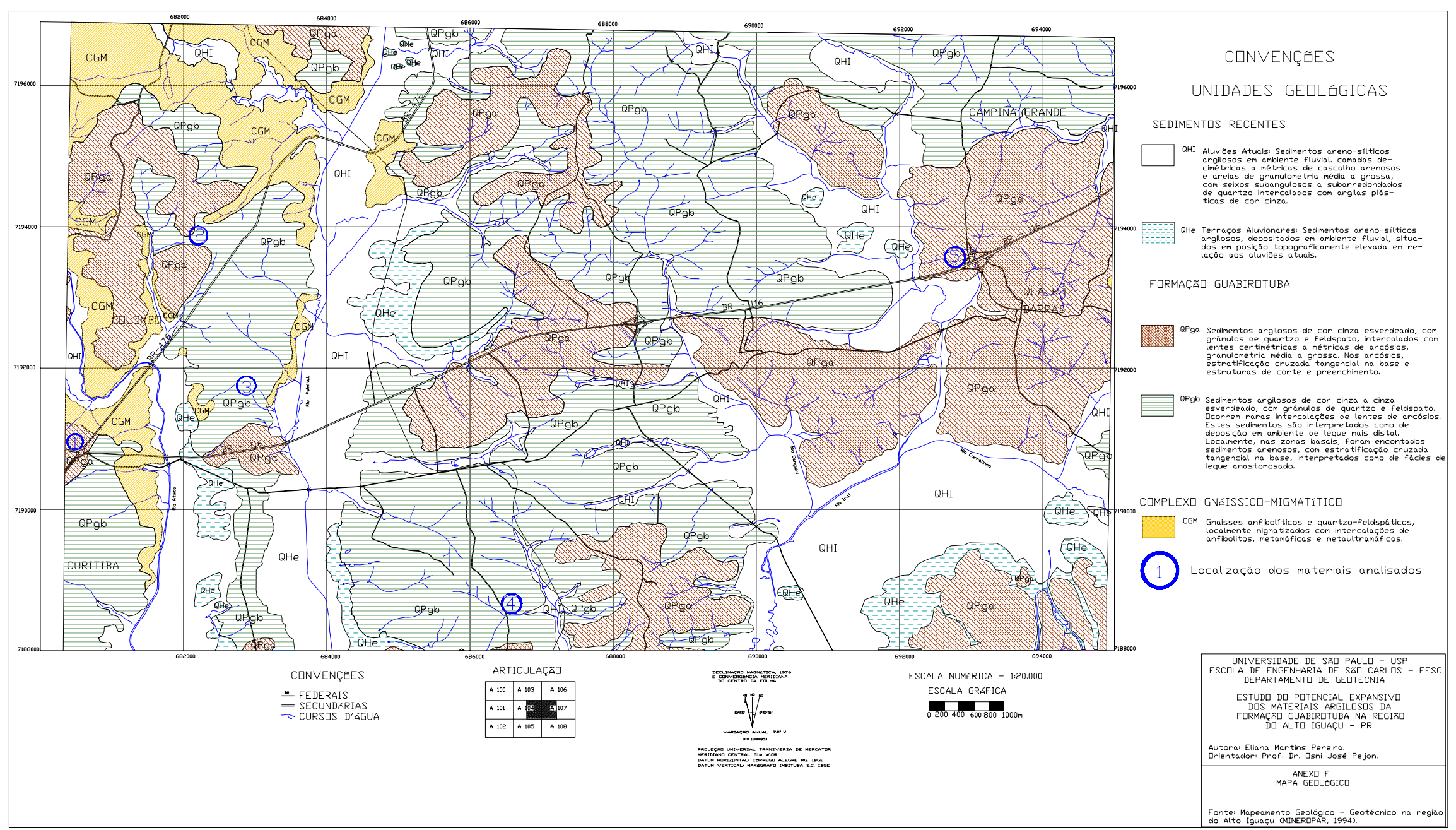

FIGURA 25. Mapa Geológico (Pereira, 1999), no qual estão representados os pontos onde foram obtidas as amostras dos materiais estudados. 
O material 1 (Figura 26), foi coletado em um talude, numa profundidade de cerca de 4,0m. Apresenta coloração marrom avermelhada, por vezes variegada, com grãos de feldspato alterado (caulim) dispersos no material.

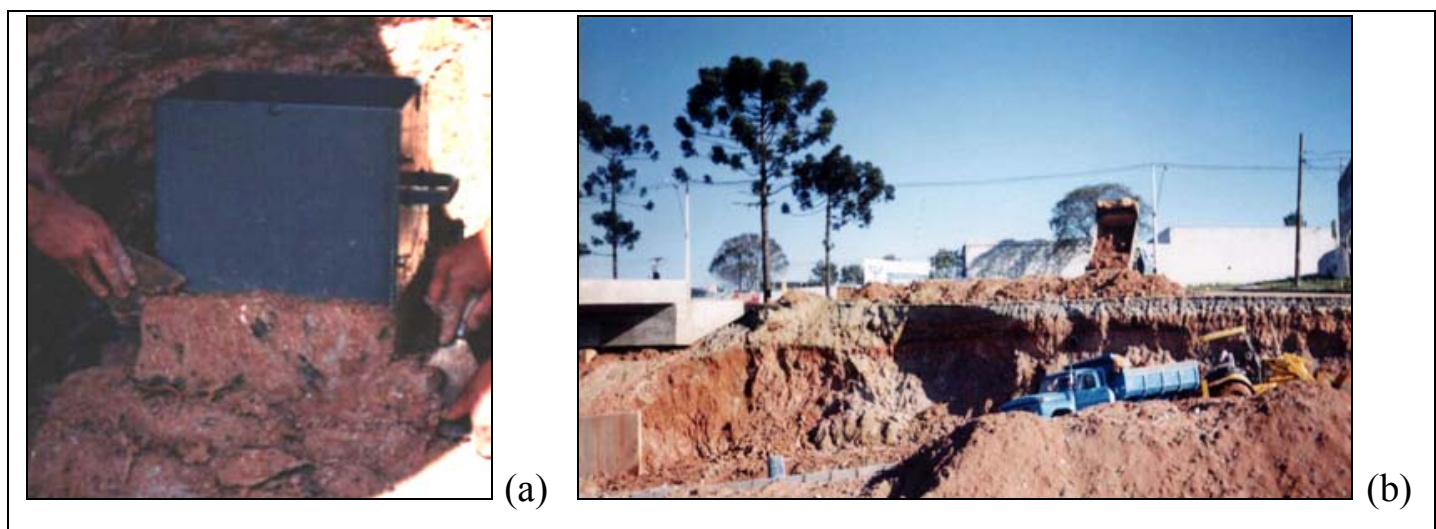

FIGURA 26. a) Aspecto do material 1 e b) Talude onde foi retirado o material 1 indeformado.

O material 2 (Figura 27), foi coletado numa profundidade de cerca de $2,0 \mathrm{~m}$, em um terreno com intenso ravinamento, devido à retirada da cobertura vegetal para novas construções. Apresenta coloração cinza avermelhada.
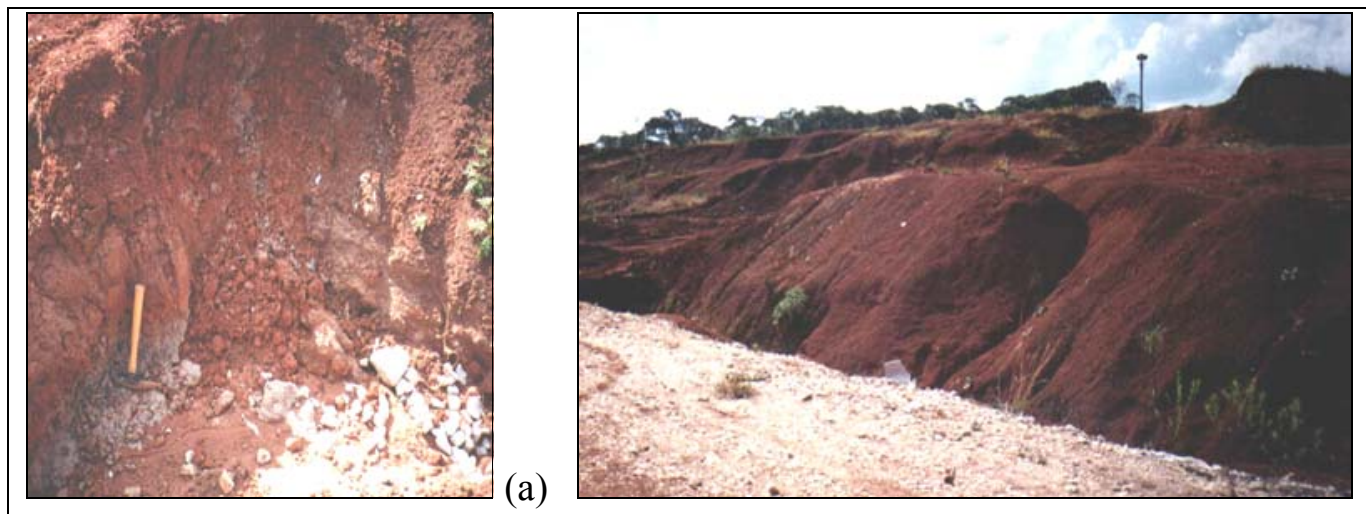

(b)

FIGURA 27. a) Aspecto do "empastilhamento" apresentado pelo material 2 quando exposto a ciclos de secagem e umedecimento e b) Local de retirada do material 2 indeformado.

O material 3 (Figura 28), foi coletado numa profundidade de cerca de 2,0m, em um afloramento de um barranco, que devido a exposição do material apresentava desmoronamento. Apresenta coloração cinza avermelhada. 


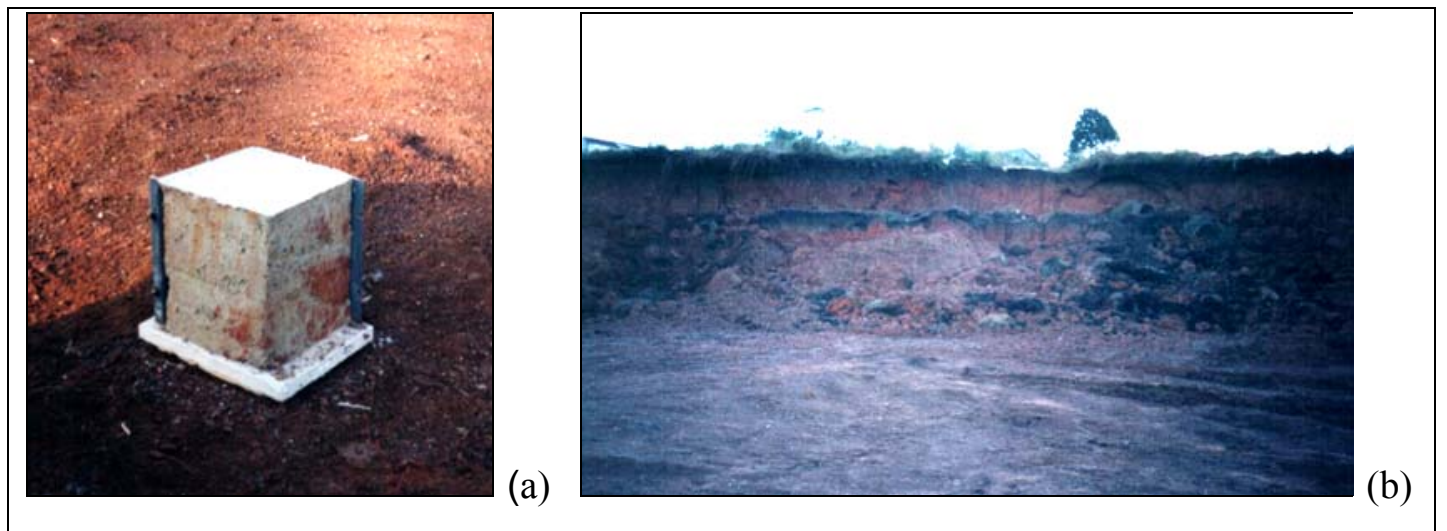

FIGURA 28. a) Material argiloso analisado e b) Local de retirada do material 3.

O material 4 (Figura 29), foi coletado em um afloramento num barranco, numa profundidade de cerca de 1,2m. O material apresenta coloração cinza esverdeada e grãos de feldspato alterado (caulim) dispersos no material.
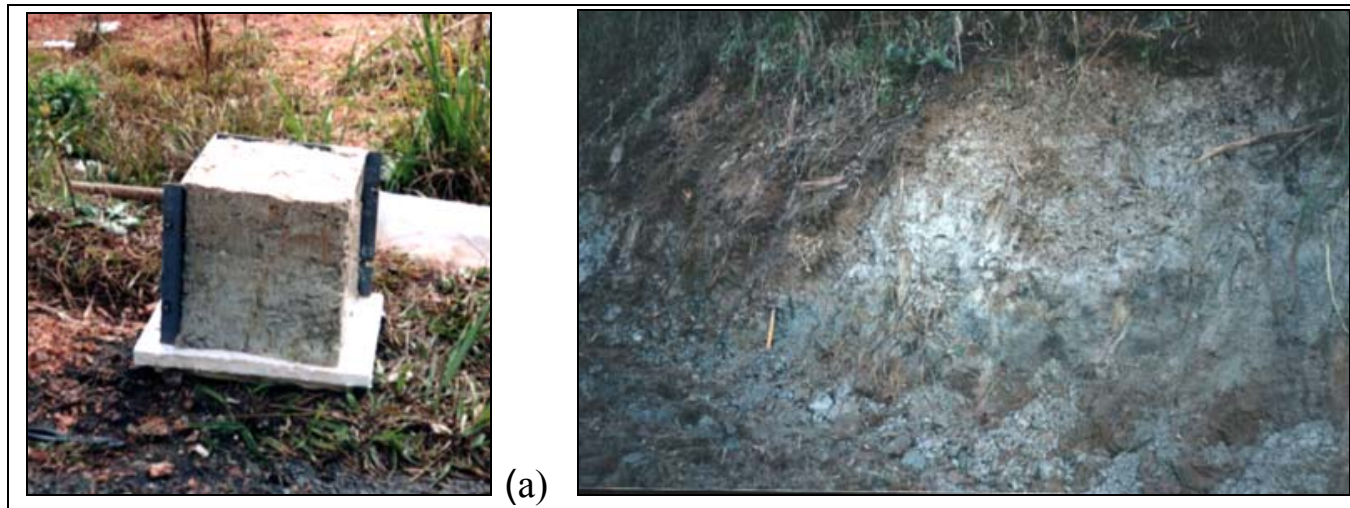

(b)

FIGURA 29. a) Aspecto do material argiloso e b) Local de retirada do material 4.

O material 5 (Figura 30), foi coletado em um afloramento com intenso ravinamento, numa profundidade de cerca de 1,0m. Apresenta coloração cinza esverdeada, com grãos de feldspato alterado (caulim) dispersos no material. 


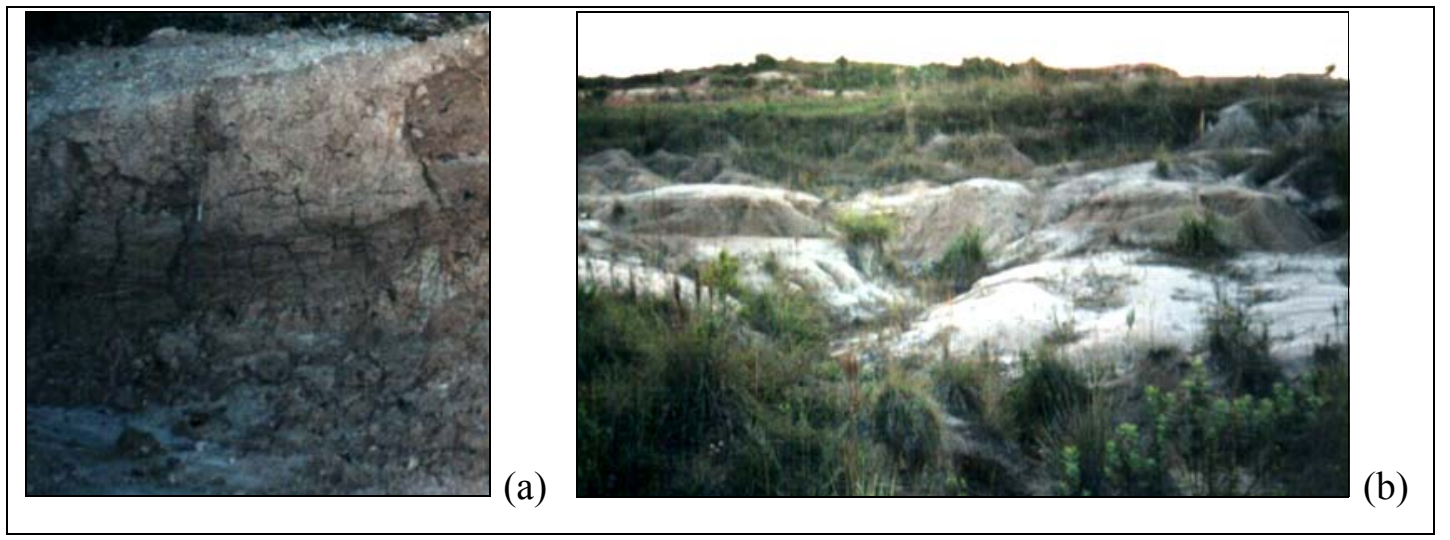

FIGURA 30. a) Aspecto do material 5 e b) Local de retirada do material 5.

\subsubsection{Amostragem}

Os materiais utilizados para a realização dos diferentes ensaios foram coletados em caixas metálicas cúbicas com $25 \mathrm{~cm}$ de lado, através de escavação manual, seguindo as recomendações para retirada, proteção e transporte sugeridas por Nogueira (1998), de forma a obter uma amostra representativa da estrutura, teor de umidade, textura e composição mineral do material na data de sua retirada. A seqüência de procedimentos utilizados, será descrita a seguir:

a) Abertura do local de retirada do material;

b) Ajuste da caixa metálica no material, pressionando-a levemente, provocando sua descida a medida que o bloco foi sendo talhado (Figura 31);

c) Corte do bloco em cunha próximo a base da caixa, para separá-lo do terreno;

d) Retirada do excesso de material e enrasamento do topo e da base do bloco;

e) Retirada da caixa metálica, deposição do bloco sobre uma base de madeira devidamente parafinada (Figura 32), aplicação de uma camada de parafina, recobrimento do material com um tecido poroso (talagarça) e aplicação de uma segunda camada de parafina;

f) Identificação do material indeformado.

Os materiais foram transportados para o laboratório em caixas de isopor e os espaços entre os blocos e as caixas de isopor, preenchidos com material plástico para absorver impactos. Em seguida, no local de destino foram devidamente armazenados em câmara úmida. 


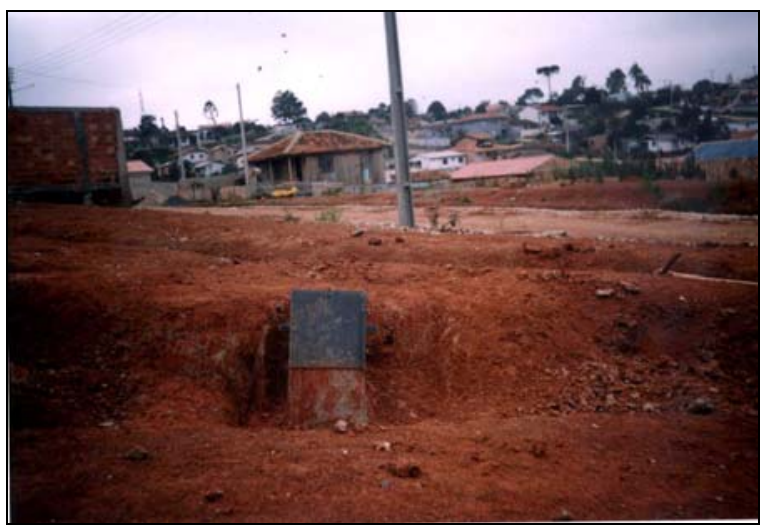

FIGURA 31. Coleta do material indeformado: ajuste da caixa metálica no material.

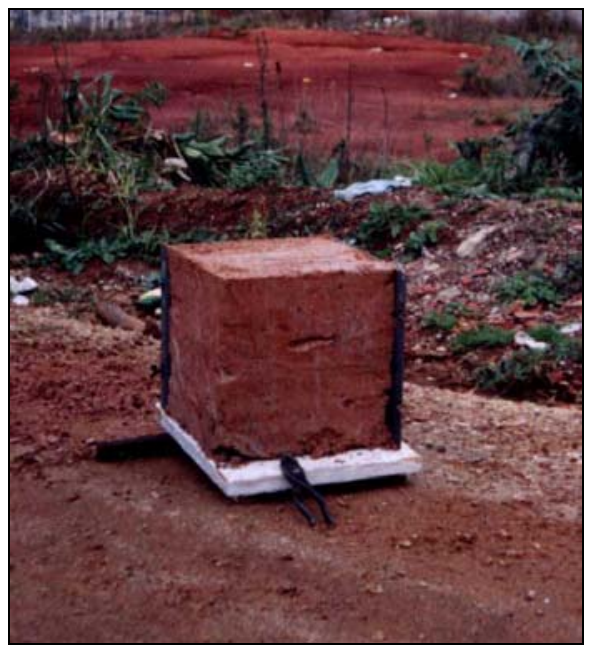

FIGURA 32. Amostragem indeformada: material pronto para ser parafinado.

\subsection{MÉTODOS DE ENSAIO UTILIZADOS}

\subsubsection{Ensaios de Caracterização}

A caracterização do material sedimentar da Formação Guabirotuba foi realizada a partir de amostras retiradas dos materiais indeformados, as quais foram utilizadas para os diferentes ensaios realizados, que serão descritos a seguir: 


\subsubsection{Análise Granulométrica, Índices Físicos e Limites de Consistência}

A caracterização do material envolveu a determinação da distribuição granulométrica e massa específica dos sólidos $\left(\rho_{\mathrm{s}}\right)$, respectivamente, segundo as normas técnicas ABNT-MB-32-NBR 7181/84 e ABNT - NBR 6508/84. A massa específica do solo $(\rho)$ foi determinada a partir da massa do solo obtida em balança e do volume do corpo de prova, e o teor de umidade (w) após secagem do material em estufa.

A massa específica seca $\left(\rho_{\mathrm{d}}\right)$, índice de vazios (e), porosidade $(n)$ e grau de saturação $\left(\mathrm{S}_{\mathrm{r}}\right)$, foram calculados a partir de fórmulas que permitem a correlação entre os índices físicos.

Os ensaios para a determinação dos Limites de Consistência foram realizados conforme as normas ABNT - NBR - 6459/80 (limite de liquidez) e NBR - 9180/82 (limite de plasticidade).

\subsubsection{Análise Térmica Diferencial (ATD)}

Este ensaio foi realizado conforme recomendado por Santos (1989), para os cinco materiais argilosos, sendo utilizado o material passante na peneira \# 400 $(0,037 \mathrm{~mm})$.

\subsubsection{Análise Térmica Gravimétrica (ATG)}

Este ensaio foi realizado para os cinco materiais argilosos, sendo utilizado cerca de $5 \mathrm{~g}$ de material que passa na peneira \# $400(0,037 \mathrm{~mm})$, segundo procedimento proposto por Santos (1989).

\subsubsection{Difração de Raios-X}

O ensaio foi realizado segundo procedimento recomendado por Moore e Reynolds (1989). Utilizou-se material fino (passante na peneira \# $400-0,037 \mathrm{~mm}$ ) que foi sedimentado em lâminas de vidro e submetido a três tratamentos diagnósticos diferenciados, ou seja, natural, glicolado e aquecido a $550^{\circ} \mathrm{C}$. Estes diferentes 
tratamentos tiveram como objetivo ressaltar diferenças de comportamento entre os diversos argilominerais.

\subsubsection{Adsorção de Azul de Metileno}

O ensaio de adsorção de azul de metileno foi realizado pelo método do papel de filtro, para todas as amostras utilizadas nos ensaios de expansão, seguindo o procedimento descrito por Pejon (1992), que consiste na utilização de material que passa na peneira \#10 (2,0mm) e concentração da solução de azul de metileno de 1,5 g/l. Os procedimentos de preparação dos materiais e execução do ensaio são descritos a seguir:

1) Preparação:

a) $\mathrm{O}$ material foi passado na peneira $\mathrm{n}^{\circ} 10(2,0 \mathrm{~mm})$;

b) Determinou-se o teor de umidade do material;

c) Pesou-se cerca de $1 \mathrm{~g}$ de material com a umidade natural;

d) Preparou-se uma suspensão do material pesado com $10 \mathrm{ml}$ de água destilada.

2) Execução:

O material utilizado para a execução do ensaio consiste em um agitador magnético, uma bureta graduada, um béquer, uma haste de vidro e papel de filtro. $\mathrm{O}$ ensaio é realizado mantendo a suspensão previamente preparada em agitação constante, e adicionando-se quantidades de azul de metileno em intervalos de três minutos. A cada intervalo de tempo, retira-se com haste de vidro uma gota da solução e coloca-se sobre o papel de filtro. Caso ocorra uma mancha azul escura, o teste é negativo, se aparecer uma auréola azul clara em torno da mancha escura, o teste é positivo. O ensaio prossegue até a obtenção do teste positivo (Figura 33). A quantidade de azul de metileno necessária para a obtenção do teste positivo é relacionada com a massa seca do solo (expressões 18 a 21) para a determinação de diferentes parâmetros como veremos a seguir.

A partir deste ensaio foram obtidas a capacidade de troca de cátions (CTC) e superfície específica (SE) da fração total do solo e da fração argila, além dos índices VB e Acb que indicam respectivamente a quantidade de azul de metileno adsorvido em 100 $\mathrm{g}$ de solo e em $100 \mathrm{~g}$ de argila contida no solo. 
Estes parâmetros e índices foram calculados a partir das seguintes expressões (Pejon, 1992):

$C T C=\frac{V * C * 100}{M s}$

$S E=\frac{3,67 * V}{M s}$

$V B=\left(\frac{V^{*} 1,5}{1000}\right) *\left(\frac{100}{M_{S}}\right)$

$\mathrm{Acb}=\frac{100 * \mathrm{VB}}{\%<0,002 \mathrm{~mm}}$

Onde: $\mathrm{CTC}=$ capacidade de troca de cátions em $\mathrm{cmol}^{(+)} / \mathrm{Kg} ; \mathrm{V}=$ volume da solução de azul de metileno adsorvido $(\mathrm{ml}) ; \mathrm{C}=$ concentração da solução de azul de metileno (em normalidade); $\mathrm{Ms}=$ massa do solo seco $(\mathrm{g}) ; \mathrm{SE}=$ superfície específica $\left(\mathrm{m}^{2} / \mathrm{g}\right) ; \mathrm{VB}=$ valor de azul de metileno adsorvido ( $\mathrm{g} / 100 \mathrm{~g}$ de solo) e $\mathrm{Acb}=$ índice de atividade da fração argilosa (g/100g argila). 


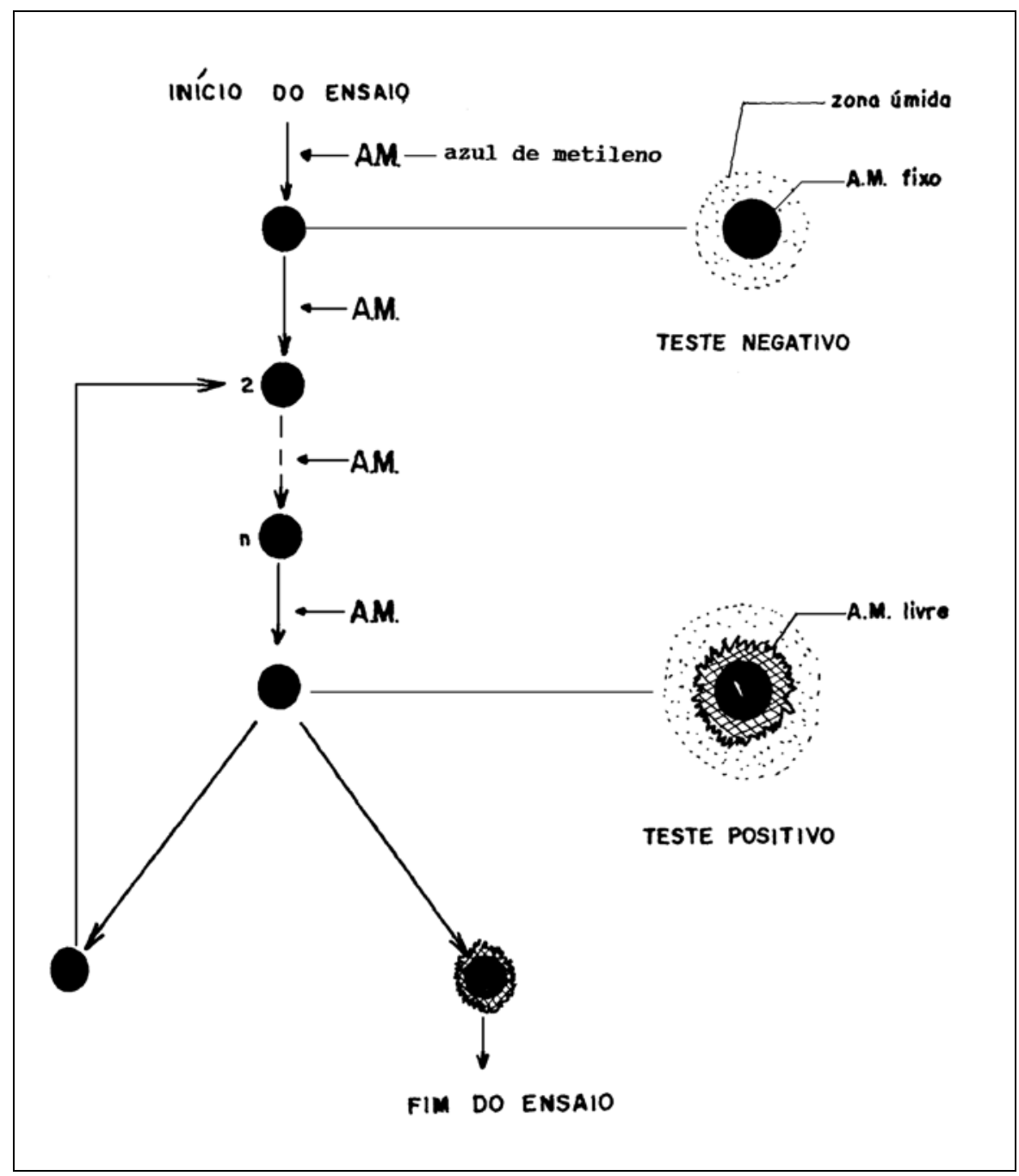

FIGURA 33. Fluxograma do ensaio de adsorção de azul de metileno pelo método do papel de filtro (Pejon, 1992).

\subsubsection{Porosimetria de Mercúrio}

Realizaram-se ensaios de porosimetria por intrusão e reintrusão de mercúrio para amostras dos cinco materiais. A finalidade deste procedimento foi a determinação da distribuição do tamanho dos poros nos materiais.

O princípio desta técnica está baseada na lei da capilaridade que governa a penetração de líquidos em pequenos poros. O volume de mercúrio que penetra nos poros é medido diretamente como uma função da pressão externa aplicada, sendo que esta depende do ângulo de contato, do tamanho e geometria dos poros e da tensão 
superficial. Neste ensaio aplica-se uma pressão para forçar o mercúrio a penetrar nos vazios interpartículas e poros intrapartículas.

As amostras utilizadas no ensaio, foram obtidas quebrando o material em pedaços com dimensões de cerca de $1,5 \mathrm{~cm}$ de lado, que foram secos ao ar e após a constância da massa, colocados em dessecador contendo sílica gel, até que fossem analisados no Instituto de Física da USP de São Carlos.

Utilizou-se o equipamento "PoreSizer 9320 da Micromeritics Instrument Corporation", que apresenta capacidade máxima de aplicação de pressão de 30000psi (cerca de $206 \mathrm{MPa}$ ) e com controle automático de pressão.

\subsubsection{Microscopia Eletrônica de Varredura}

A microscopia eletrônica de varredura foi utilizada para analisar amostras dos cinco materiais argilosos. As amostras observadas no ensaio foram obtidas a partir da quebra do material, perpendicular a direção de deposição deste, com dimensões de cerca de $1 \mathrm{~cm}$ de lado. As amostras foram primeiramente secas ao ar, depois colocadas em estufa com temperatura máxima de $50^{\circ} \mathrm{C}$, e posteriormente metalizadas com uma camada fina de ouro, para que pudessem ser analisadas. Os procedimentos de análise seguiram as recomendações de Goldstein et al. (1992).

Estes ensaios foram realizados no Instituto de Física da USP de São Carlos e no Departamento de Geologia Aplicada da UNESP de Rio Claro.

\subsubsection{Determinação da Curva de Retenção de Água}

Para a obtenção da curva de retenção de água em laboratório, pode-se seguir dois processos: o de infiltração (umedecimento) ou de drenagem (secagem) da água contida no material. O principal objetivo de se obter essas curvas, é a avaliação da sucção em função da umidade do material.

Neste trabalho foram utilizadas duas técnicas para a determinação da Curva de Retenção de Água pelo processo de secagem, sendo uma pelo Método da Câmara de Pressão de Richards (1940) e a outra através do Método do Papel Filtro (Marinho, 1995). Destes foram obtidos dados de sucção matricial e total $(\mathrm{kPa})$ versus umidade gravimétrica $(\%)$. 
A determinação da Curva de Retenção de Água pelo processo de umedecimento, foi realizada através da técnica de imposição de umidade relativa no dessecador de vácuo, onde obteve-se dados de sucção total $(\mathrm{kPa})$ versus umidade gravimétrica $(\%)$.

Cabe ressaltar que para todos os métodos a quantidade de água no solo foi dada em termos de umidade gravimétrica (\%), que segundo Fredlund (2000), é a representação mais precisa deste parâmetro quando se trata de solos deformáveis, além de ser mais comumente utilizada em Mecânica dos Solos. A dificuldade de medição precisa da mudança do volume do material prejudicaria os resultados do teor de umidade volumétrica, visto que, este parâmetro depende desse dado para sua determinação.

Para os dados experimentais obtidos para os materiais argilosos, foram realizados ajustes da curva de retenção com seis modelos matemáticos (equações 8 a 13), propostos por Farrel e Larson (1972), Simmons et al. (1979), Libardi et al. (1979), Van Genuchten (1980) e Driessen (1986)), utilizando o Programa Computacional Soil Water Retention Curve (SWRC) desenvolvido por Dourado Neto et al. (2000) e através do modelo de Fredlund et al. (1994) a partir do Programa Computacional Soil Water Characteristic Curve (SWCC) de Santos e Vilar (1999/2000). O objetivo deste procedimento, visou a obtenção de um modelo ou modelos que melhor se ajustassem a estes tipos de materiais.

Adicionalmente, realizou-se a calibração do papel filtro Whatman $\mathrm{n}^{\circ} 42$, a partir de soluções salinas saturadas e aquosas, que será descrito mais adiante.

\subsubsection{Método da Câmara de Pressão de Richards}

As curvas de retenção de água pelo processo de secagem foram obtidas na câmara de Pressão com Placa Porosa ou de Richards (1940), segundo procedimento descrito em Libardi (1995).

Para o ensaio foram moldados para cada um dos cinco materiais, três corpos de prova cilíndricos, com diâmetros entre 5,26 e 5,35 e alturas entre 0,98 e 1,03cm. Os corpos de prova foram colocados sobre a superfície da placa cerâmica e o conjunto foi submerso parcialmente (até a metade da altura dos corpos de prova) em água destilada para a saturação dos mesmos (Figura 34). Esta saturação foi realizada por um período de 24 horas. 
Em seguida, o conjunto foi colocado no interior da câmara (Figura 35) e foram aplicadas pressões sucessivas de ar $(10,50,100,300,400,600,780 \mathrm{kPa})$. Assim, a sucção induzida foi transmitida ao material, alcançando-se um equilíbrio depois da eliminação parcial da água em cada estágio. Em cada estágio o corpo de prova foi pesado para determinação do seu teor de umidade, sendo que, na condição final de equilíbrio, a pressão de ar aplicada é igual à sucção do material, visto que a pressão na água é a atmosférica.

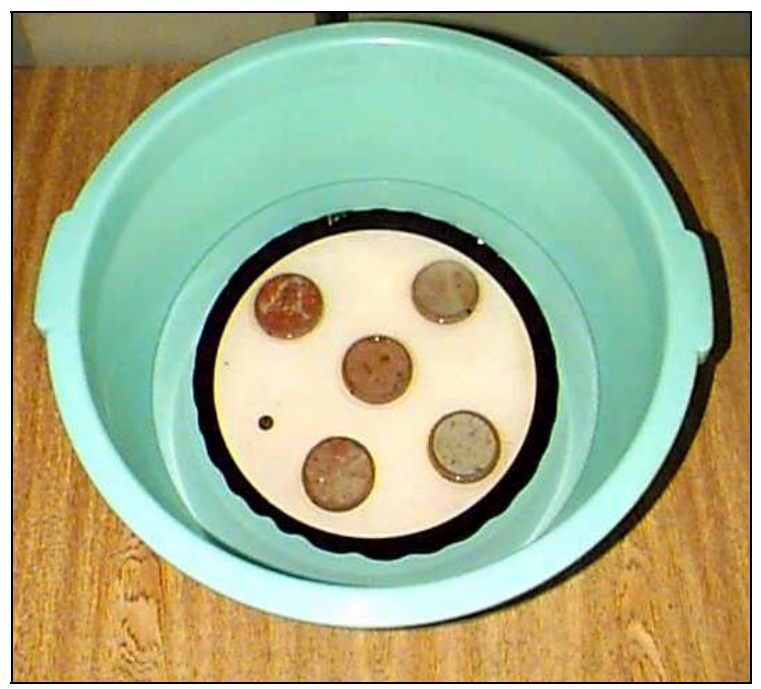

FIGURA 34. Saturação da placa porosa e dos materiais antes de iniciar o ensaio.

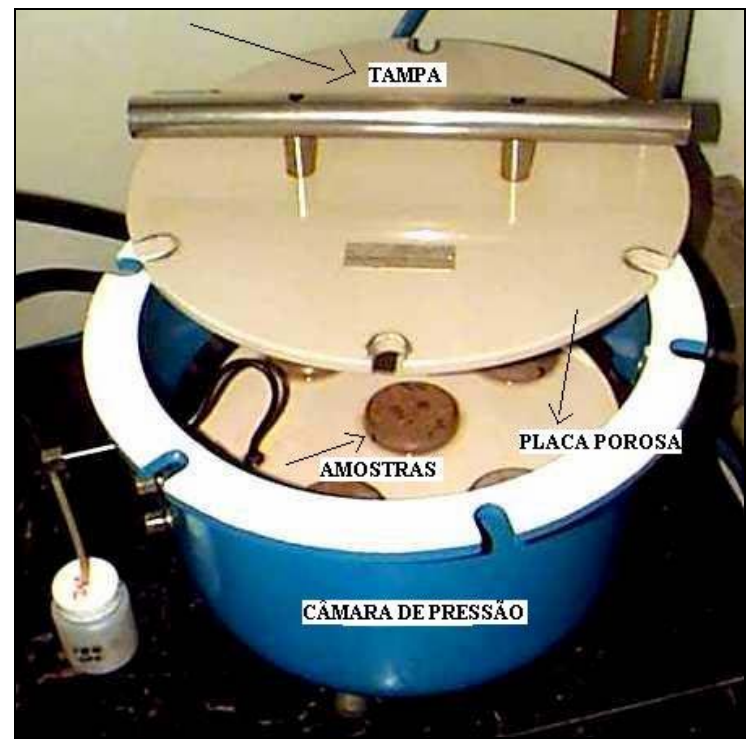

FIGURA 35. Câmara de pressão de Richards (1940) utilizada. 


\subsubsection{Método do Papel Filtro}

As sucções matricial e total dos cinco materiais estudados foram determinadas através da Técnica do Papel Filtro, pelo processo de secagem, conforme procedimento descrito por Marinho (1995).

Para a obtenção da sucção matricial foram talhados para cada material, 20 corpos de prova cilíndricos, com exceção do material 1, para o qual foram retirados 21 corpos de prova, com diâmetros entre 3,72 e 3,80cm e alturas entre 0,98 e 1,03cm.

Para a obtenção da sucção total foram talhados para cada material, 16 corpos de prova cilíndricos, com exceção do material 5, para o qual foram retirados 15 corpos de prova, com diâmetros entre 3,71 e $3,80 \mathrm{~cm}$ e alturas entre 0,98 e $1,04 \mathrm{~cm}$.

Para os dois procedimentos, o início do ensaio foi a partir da condição de saturação, portanto, os corpos de prova foram assentados num papel filtro e o conjunto sobre uma pedra porosa que encontrava-se parcialmente submersa em água destilada. $\mathrm{O}$ tempo de imersão foi de 24 horas.

Após a saturação, os corpos de prova foram deixados secar até que atingissem o teor de umidade desejado. A umidade final de cada um deles foi previamente calculada a partir dos índices físicos e posteriormente, controlados por pesagens sucessivas dos corpos de prova, a fim de obter pontos com teores de umidade, que representassem o material desde a saturação até seco.

Uma vez atingida a umidade desejada, para a determinação da sucção matricial, foram colocados sobre cada superfície da amostra, um papel filtro Whatman $n^{\circ} 42$ com diâmetro pouco menor que do material, em contato direto com amostra (Figura 36). A diferença do procedimento para a determinação da sucção total, é que neste caso, se evitou o contato direto entre o papel e o solo colocando entre eles uma rede de naylon. O papel e o disco de nylon foram inseridos dentro de um disco de PVC $(4,0 \mathrm{~cm}$ de diâmetro), provido de uma pequena câmara obtida por um rebaixo no disco e com dimensões de 3,4cm de diâmetro e 2,00 mm de profundidade (Figura 37).

Em ambos os casos, cada conjunto foi embrulhado hermeticamente com um filme plástico, e firmemente envolto com fita adesiva para garantir um contato firme entre papel-amostra e colocado na câmara úmida com a finalidade de que fosse atingido o equilíbrio de umidade entre o papel e o material. Para a determinação da sucção matricial, o material permaneceu na câmara úmida por cerca de 10 dias e para a obtenção da sucção total, por cerca de 35 dias. Os tempos de equilíbrio do material na 
câmara para a determinação das sucções matricial e total foram os sugeridos por Marinho (1995).

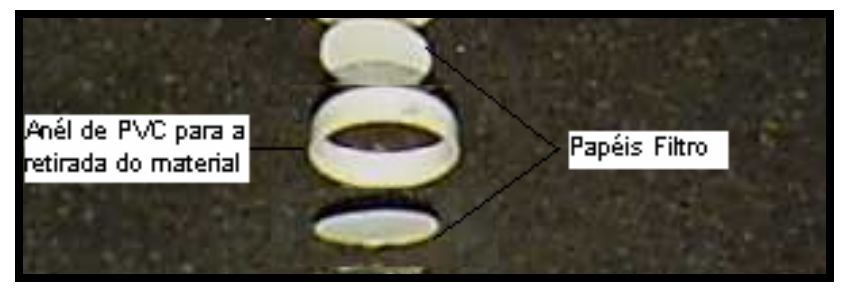

FIGURA 36. Arranjo para a determinação da sucção matricial.

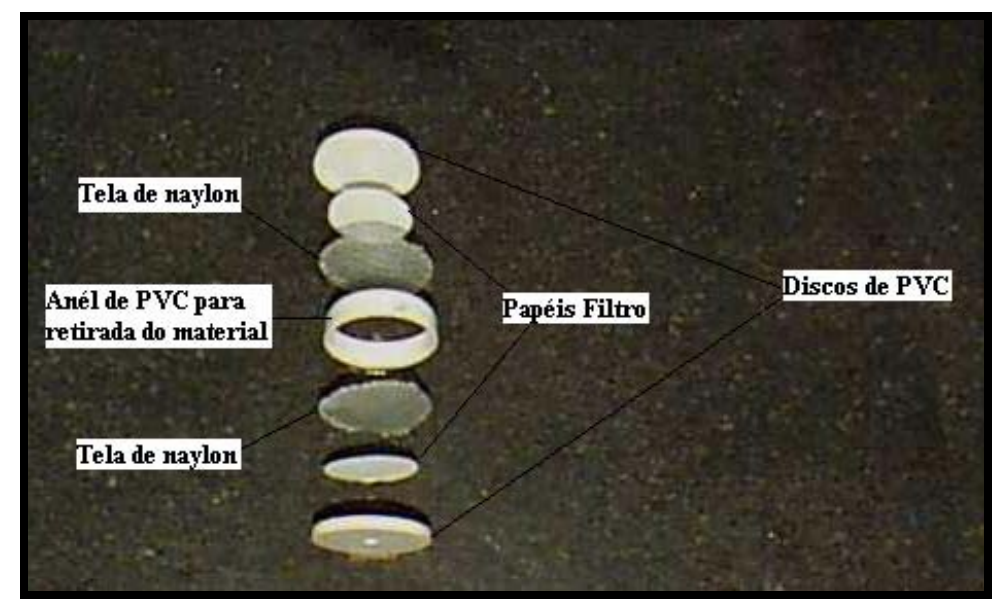

FIGURA 37. Arranjo para a determinação da sucção total.

Após este período, os papéis foram retirados e pesados imediatamente (balança com resolução de $0,0001 \mathrm{~g}$ ), sendo colocados na estufa para secagem (tempo mínimo de 2 horas à $110^{\circ} \mathrm{C}$ ) e posteriormente pesados, sempre evitando a variação da umidade. Com a amostra de material correspondente determinou-se o teor de umidade.

Calcularam-se as umidades de equilíbrio dos papéis e do material de cada amostra. Com a umidade do papel determinou-se a sucção matricial/total, utilizando-se as curvas de calibração para o papel filtro Whatman $n^{\circ} 42$ obtidas por Chandler et al. (1992), que são expressas pelas equações:

Para umidades do papel filtro $>47 \%$ :

Sucção $(\mathrm{kPa})=10^{(6,05-2,48 \log \mathrm{w})}$ 
Para umidades do papel filtro $\leq 47 \%$ :

Sucção $(\mathrm{kPa})=10^{(4,84-0,0622 \mathrm{w})}$

Como foram determinadas por ajuste, tanto a sucção total, como a sucção matricial, relativas a cada teor de umidade do material, foi possível através dos resultados calcular a sucção osmótica pela diferença entre eles.

\subsubsection{Método do dessecador de vácuo}

Foram realizadas Curvas de retenção de água através do método do dessecador de vácuo (Figura 38), no qual a sucção é controlada através da imposição da umidade relativa dentro do dessecador que varia de acordo com o tipo e concentração da solução utilizada (Jucá, 1993). Este ensaio foi executado pelo processo de umedecimento para amostras dos 5 materiais argilosos. Para este fim, foram utilizadas amostras com dimensões de cerca de 4,82 a 3,84cm de diâmetro e 1,50 a 1,04cm de altura, que foram inicialmente submetidas a secagem, até a constância da massa e colocadas em dessecador, que continha solução salina.

Foram utilizadas soluções salinas saturadas de cloreto de sódio, cloreto de potássio e de cloreto de bário, que permitiram impor às amostras, umidades relativas que traduzidas para sucções totais mediante a expressão (24) forneceram sucções de cerca de 40, 24 e $15 \mathrm{MPa}$, respectivamente, preparadas de acordo com a Norma ASTM E 104-85 (1991) e soluções salinas aquosas com diferentes concentrações, que geraram umidades relativas que correspondem a 5, 3 e 1 MPa (Lang, 1967).

A relação entre a sucção e a umidade relativa é dada pela lei de Kelvin, a partir da expressão abaixo (Delage et al., 1997):

$\mathrm{u}_{\mathrm{a}}-\mathrm{u}_{\mathrm{w}}=\frac{\mathrm{RT}}{\mathrm{Mg}} \ln \frac{\mathrm{P}}{\mathrm{Po}}$

Onde: $\mathrm{u}_{\mathrm{a}}, \mathrm{u}_{\mathrm{w}}=$ pressão do ar e da água, respectivamente; $\mathrm{R}=$ constante de gases perfeitos $\left(8,3143 \mathrm{~J} \mathrm{~mol} \mathrm{~K}^{-1}\right) ; \mathrm{T}=$ temperatura absoluta $\left(293^{\circ} \mathrm{K}\right.$ para $\left.20^{\circ} \mathrm{C}\right) ; \mathrm{M}=$ massa molar da água $\left(18,016 \mathrm{~g} \mathrm{~mol}^{-1}\right) ; \mathrm{g} .=$ aceleração gravitacional $\left(9,81 \mathrm{~ms}^{-2}\right) ; \mathrm{P} / \mathrm{Po}=$ umidade relativa, igual a pressão parcial de vapor (P) dividida pela pressão de vapor de saturação (Po); $\mathrm{RT} / \mathrm{Mg}=137.837 \mathrm{kPa}$. 


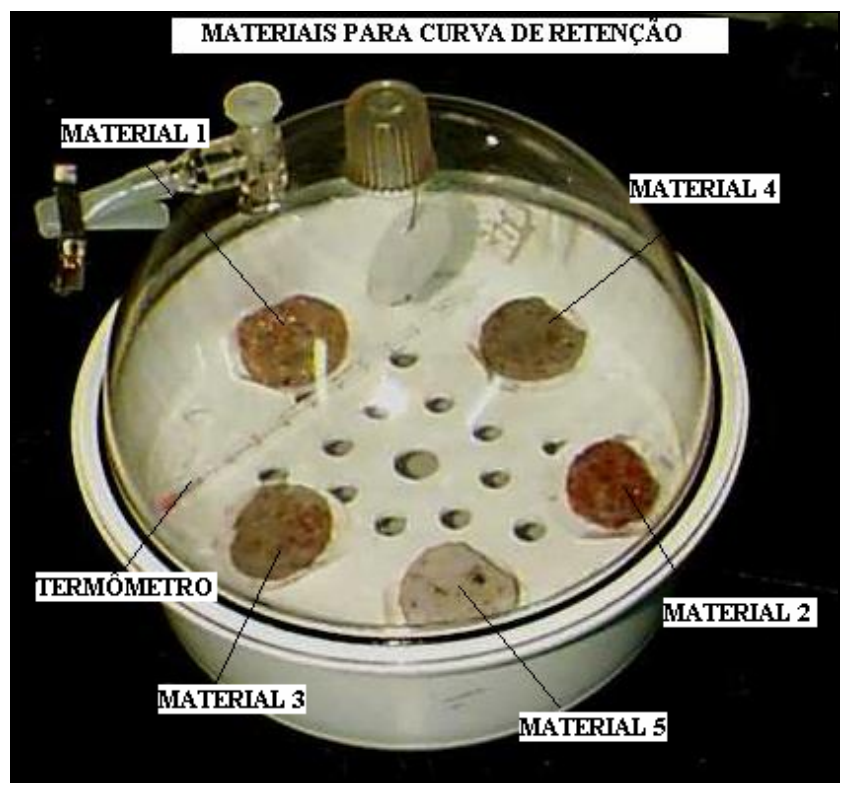

FIGURA 38. Amostras sendo submetidas à imposição de sucção no dessecador de vácuo.

As amostras foram mantidas dentro do dessecador com cada solução salina, até que atingissem o equilíbrio de umidade, que foi controlado por pesagens sucessivas dos corpos de prova até que não houvesse variações significativas de peso, indicando que a transferência de água em forma de vapor havia sido finalizada. Com o objetivo de acelerar os processos de transferência de vapor, foi aplicado dentro do dessecador um vácuo de $40 \mathrm{kPa}$ com auxílio de uma bomba de vácuo manual. Como este ensaio necessita de um rigoroso controle de temperatura, as amostras foram colocadas numa sala climatizada. Os resultados determinaram a relação entre teor de umidade gravimétrica $(\%)$ versus sucção total $(\mathrm{kPa})$.

Visto que, a umidade relativa (e conseqüentemente a sucção total) varia em função da temperatura, foi necessária a correção das sucções ao final dos ensaios para as temperaturas de equilíbrio, que serão mostradas no próximo capítulo.

\subsubsection{Calibração do Papel Filtro}

O procedimento para a calibração consiste em permitir que o papel filtro atinja o estado de equilíbrio com uma sucção conhecida (Marinho, 1995).

A calibração dos papéis filtro Whatman $n^{0} 42$ (Figura 39), seguiu o mesmo procedimento descrito anteriormente, sendo utilizadas as mesmas soluções salinas 
saturadas e aquosas para a realização da curva de retenção de água. $\mathrm{O}$ controle de peso dos papéis filtro foi realizado em balança com resolução de $0,0001 \mathrm{~g}$. Após o equilíbrio de vapor para cada sucção, os papéis foram secos em estufa por cerca de 2 horas, para a determinação do teor de umidade correspondente a cada sucção imposta.

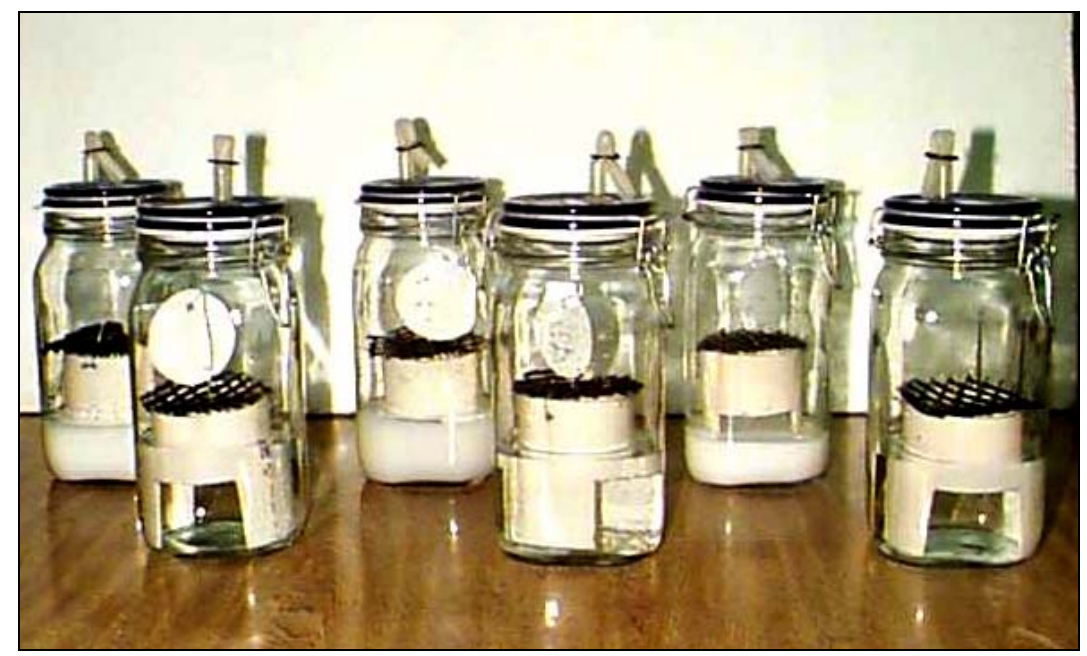

FIGURA 39. Calibração dos papéis filtro Whatman $n^{\circ} 42$.

\subsubsection{Determinação da Condutividade Elétrica do Extrato Aquoso}

Segundo Camargo et al. (1986), a salinidade de um solo, tanto natural como ocasionada por sais nele colocados, pode ser medida pela condutividade elétrica do extrato. A condutividade é aproximadamente proporcional a quantidade de sal da solução, dando uma indicação da concentração de constituintes ionizados.

Como o ensaio teve por objetivo apenas ter uma estimativa da salinidade do material, o método para preparar o extrato, ou seja, a proporção água/solo neste caso, foi de $1: 1$.

Para todas as amostras foram pesados $200 \mathrm{~g}$ de material seco ao ar, adicionados $200 \mathrm{ml}$ de água destilada, agitado manualmente por cerca de 30 segundos, a cada meia hora, cinco vezes, durante 2 horas. Após este procedimento a mistura foi filtrada lentamente em papel filtro (Whatman $\mathrm{n}^{\circ} 42$ ) e procedida a leitura no condutivímetro.

Como calculou-se a sucção osmótica a partir da determinação da sucção matricial/total através do ensaio de papel filtro, o ensaio de condutividade elétrica foi realizado com o objetivo de observar uma relação entre a concentração de sais 
provenientes da solução do material, medidas pelo condutivímetro e a sucção osmótica dos mesmos.

\subsubsection{Ensaios de Expansão}

Para avaliar o potencial à expansão dos materiais foram realizados ensaios de pressão de expansão. Estes foram conduzidos com auxílio de ensaios edométricos convencionais e adicionalmente sob sucção controlada, este último, valendo-se das técnicas de translação de eixos e da imposição da umidade relativa para o controle da sucção.

\subsubsection{Ensaio edométrico convencional utilizando o método da amostra a volume constante}

Para a obtenção da pressão de expansão dos materiais argilosos, utilizou-se o método a volume constante proposto pela Associação Internacional de Mecânica das Rochas (ISRM, 1989).

De forma geral, o método consiste em confinar uma amostra numa célula edométrica (Figura 40), aplicar uma pré-carga inicial de $25 \mathrm{kPa}$, apenas para ajuste do sistema, inundar a amostra com água destilada e a cada deslocamento vertical de $0,01 \mathrm{~mm}(0,05 \%)$, aumentar a carga sobre a amostra até que a expansão seja compensada, ou seja, retorne ao valor inicial (altura inicial da amostra). O processo continua até que se estabilize a deformação, sendo que a pressão equivalente para que isto ocorra corresponde à pressão máxima de expansão. Os dados obtidos são apresentados em gráficos de Pressão de Expansão (kPa) versus tempo (h).

Este ensaio foi realizado para amostras com umidades naturais, secas ao ar e com sucção imposta por soluções salinas. As amostras utilizadas para os ensaios foram talhadas em corpos de prova cilíndricos, a partir dos cinco materiais indeformados.

Os corpos de prova para as amostras com umidades naturais e secas ao ar foram confinados lateralmente em anéis metálicos, com diâmetros de 7,02 e 7,00 cm e alturas de 1,92 e $1,88 \mathrm{~cm}$ e com diâmetros entre $7,60-6,99 \mathrm{~cm}$ e alturas entre $1,87-2,05 \mathrm{~cm}$, respectivamente. 


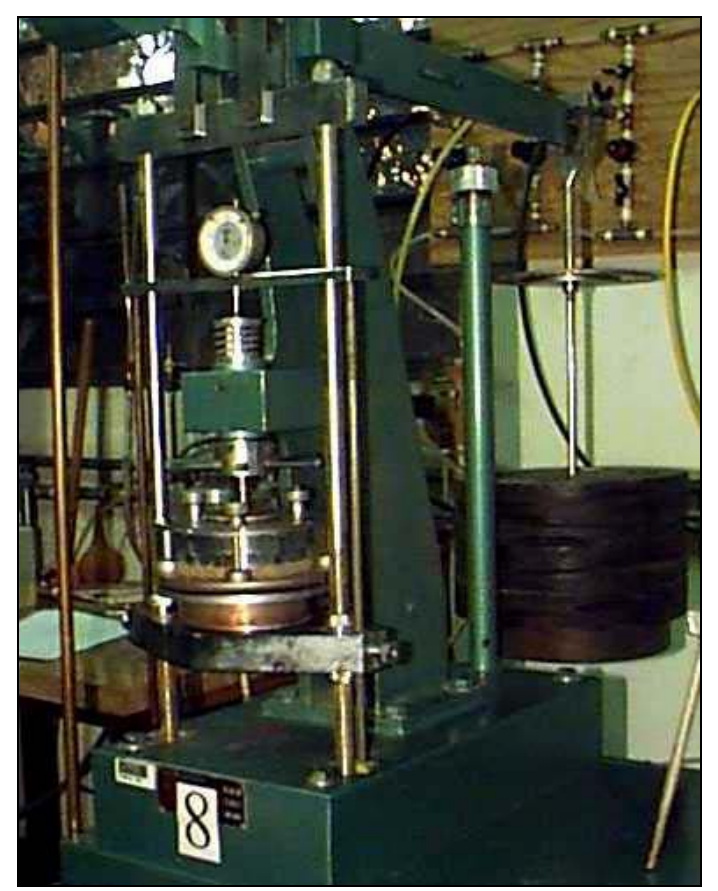

FIGURA 40. Equipamento utilizado para o ensaio de Pressão de Expansão a volume constante.

As amostras submetidas à imposição de sucção pelo processo de umedecimento, foram inicialmente secas ao ar, até a constância da massa e posteriormente moldadas em anéis metálicos com diâmetros entre 7,04-6,99 $\mathrm{cm}$ e alturas entre 2,07-1,91 cm. Posteriormente, para a imposição da sucção as amostras foram colocadas em dessecadores que continham soluções salinas (Figura 41), neste caso, foram utilizadas soluções saturadas de cloreto de sódio, de potássio e de bário preparadas de acordo com a Norma ASTM E 104-85 (1991), e que segundo a norma são capazes de impor sucções totais da ordem de 40, 24 e $15 \mathrm{MPa}$ respectivamente. Foram utilizadas também, soluções salinas de cloreto de sódio com concentrações para imposição de sucções de 5 , 3 e $1 \mathrm{MPa}$ (Lang, 1967).

Apesar das amostras se encontrarem dentro de uma sala climatizada, ocorreram variações de temperatura. Portanto, devido à sensibilidade da umidade relativa e conseqüentemente da sucção final às mudanças de temperatura, fez-se a correção da sucção para as temperaturas de equilíbrio. 


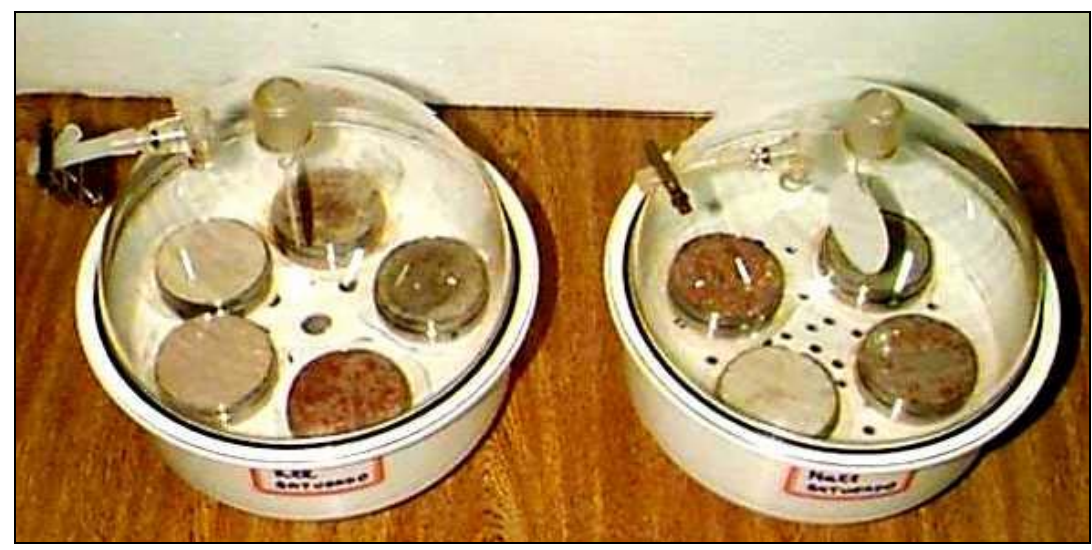

FIGURA 41. Imposição da Umidade Relativa através do método do dessecador de vácuo.

Quando alcançada a sucção de equilíbrio para cada amostra, estas foram imediatamente ensaiadas, tomando-se cuidados para evitar mudanças de temperatura e umidade da amostra o que levaria conseqüentemente à mudanças na sucção imposta. $\mathrm{O}$ procedimento de ensaio foi o mesmo descrito anteriormente para determinação das pressões de expansão citadas acima.

\subsubsection{Edômetro com controle de sucção de Escario baseado na técnica de translação de eixos}

Inicialmente utilizou-se para medir a deformação dos materiais argilosos, o edômetro sob sucção controlada, baseado no edômetro de Escario (1967, 1969). O princípio de funcionamento do equipamento baseia-se na técnica de translação de eixos proposta por Hilf (1956), possuindo uma pedra porosa de alto valor de ar (15 bar) em sua base.

De acordo com Presa (1984), o método consiste na retirada de um corpo de prova num anel similar ao do edômetro convencional, que é colocado em contato com a placa porosa resistente a altas pressões de entrada de ar $(1500 \mathrm{kPa})$ dentro da câmara de pressão. Na parte superior do corpo de prova é colocado uma pedra porosa, que permite a entrada da pressão de ar introduzida na câmara, nos poros do solo.

Este ensaio tinha como finalidade, verificar a pressão de expansão por umedecimento dos materiais em diferentes estágios de sucção. Para isto, as amostras 
dos materiais foram inicialmente saturadas e logo foi imposta uma sucção inicial máxima, que foi a partida para os ensaios de pressão de expansão por este processo.

A saturação das amostras foi realizada por contrapressão, num aparelho de compressão triaxial. Este procedimento foi utilizado, devido ao elevado teor de argila, que dificultava a saturação completa do material por capilaridade. Logo, os materiais foram moldados em anéis cilíndricos com dimensões de $6,56 \mathrm{~cm}$ de diâmetro e $2,04 \mathrm{~cm}$ de altura e posteriormente, confinados dentro da câmara edométrica.

Inicialmente aplicou-se uma pressão de $900 \mathrm{kPa}$ e a quantidade de água expulsa do corpo de prova, foi monitorada através de uma bureta, conectada à câmara até que não ocorressem variações de volume de água, o que se adotou como o equilíbrio da sucção. Após esse equilíbrio, a pressão de ar foi sendo reduzida em estágios para 600, 400, 200 $\mathrm{kPa}$ e à pressão atmosférica. Dos resultados observou-se que nestes testes as amostras não apresentaram deformações.

Com base nos resultados acima descritos, optou-se por realizar outro teste impondo na amostra a sucção máxima possível pelo sistema de ar comprimido, de $900 \mathrm{kPa}$ para depois ser retirada da câmara e ensaiada segundo o indicado no item 4.2.4.1, com a finalidade de observar se haveria diferença na deformação em ambos os processos. Este procedimento mostrou uma leve pressão de expansão, que poderá ser observada nos resultados dos ensaios.

Disto concluiu-se, que para o propósito do estudo, os resultados dos ensaios no edômetro sob sucção controlada, não foram satisfatórios, porque havia a necessidade de impor às amostras pressões de ar mais elevadas (teores de umidade mais baixos), que permitissem resultados de pressões de expansão mais expressivos. Visto que a capacidade máxima do equipamento aqui empregado, é da ordem de $900 \mathrm{kPa}$ optou-se em utilizar uma outra técnica, que permitisse alcançar sucções mais altas e que será descrita a seguir.

\subsubsection{Ensaios edométricos utilizando a técnica de controle de sucção por imposição da umidade relativa}

Para estudar o processo de expansão como uma função de mudanças de umidade, controlando a sucção, foram projetadas e confeccionadas duas câmaras edométricas baseadas no controle de sucção por imposição de umidade relativa (Figura 42), similares à desenvolvida por Esteban e Sáez (1988), com algumas modificações 
consideradas necessárias para este estudo. A técnica utilizada no equipamento consiste em instalar a sucção total através da pressão parcial de vapor de água em equilíbrio com a água do solo.

O princípio do método é o mesmo utilizado no dessecador de vácuo para medir a relação sucção/conteúdo de água, controlando a sucção através da pressão parcial de vapor ou umidade relativa, existente na câmara fechada, onde é posta a amostra.

Os ensaios foram realizados pelo processo de umedecimento com os materiais três e cinco, sendo o primeiro bastante argiloso e o segundo mais arenoso, com o objetivo de observar o comportamento de materiais com diferentes texturas.

As amostras ensaiadas foram inicialmente secas ao ar até a constância de peso e posteriormente confinadas lateralmente em anéis cilíndricos com dimensões de $7,0 \mathrm{~cm}$ de diâmetro e 2,0 cm de altura, sendo colocadas com as faces superior e inferior em contato com pedras porosas de alta permeabilidade. O anel porta amostra é preso por um anel fixador. Sobre a pedra porosa superior foi colocado um cabeçote metálico perfurado (para permitir a entrada da água na amostra em forma de vapor) que recebe a carga aplicada pela prensa, que é transmitida através de um êmbolo metálico. A solução é colocada num recipiente metálico que é suspenso a $4 \mathrm{~cm}$ acima do corpo de prova. Todo o conjunto é confinado em uma câmara de material acrílico, cujos extremos possuem o'rings, necessários para a vedação e aplicação do vácuo $(40 \mathrm{kPa})$ dentro dela. Finalmente, essa câmara é confinada pelo topo e base como mostrado na Figura 43.

A sucção foi pré-estabelecida de acordo com o interesse deste estudo e foi imposta nas amostras através de soluções salinas, que dependendo da concentração, geram umidades relativas que vão impor às amostras diferentes sucções. Os valores de sucção impostos foram de cerca de 40, 24 e $15 \mathrm{MPa}$, mediante soluções saturadas de cloreto de sódio, de potássio e de bário, respectivamente, preparadas de acordo com a Norma ASTM E 104-85 (1991) e solução salina aquosa de cloreto de sódio com concentração para imposição de sucção de 5, 3 e 1 MPa (Lang, 1967). 


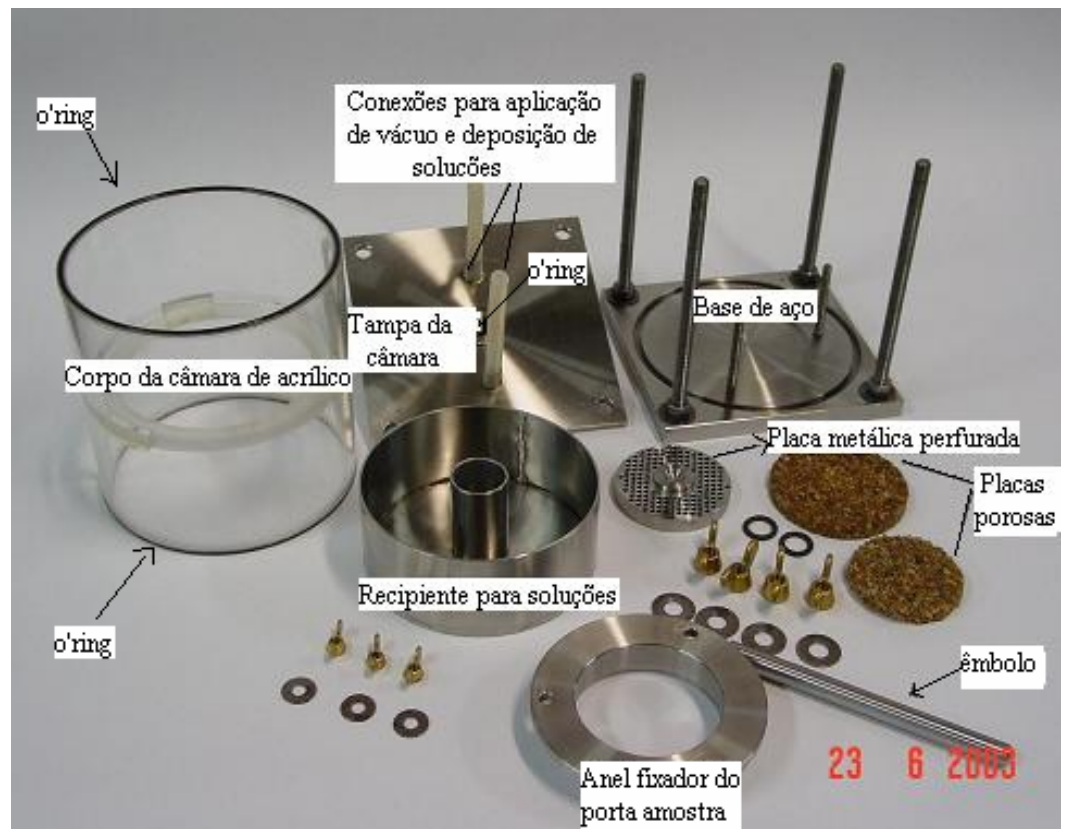

FIGURA 42. Peças confeccionadas para o edômetro com imposição de umidade relativa.

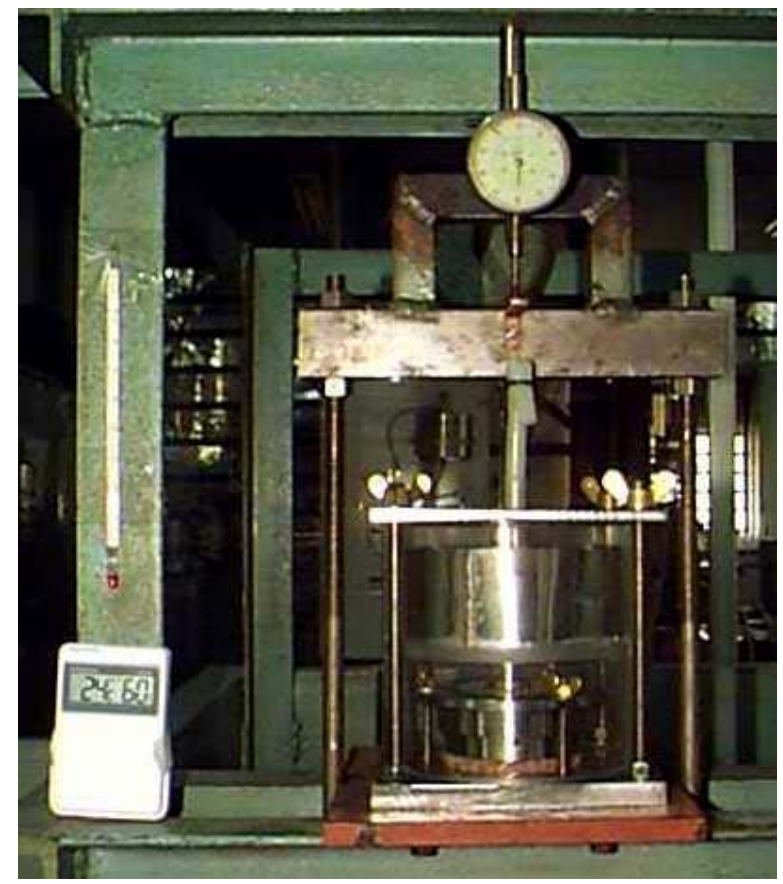

FIGURA 43. Equipamento utilizado para a realização do ensaio edométrico com imposição de umidade relativa. 
Adicionalmente, tendo em vista o tempo muito prolongado requerido para o equilíbrio de umidade através dos dois edômetros acima descritos, foram construídos complementarmente para os materiais restantes, quatro dessecadores com acoplamentos que permitem a medida do deslocamento vertical das amostras mediante extensômetros e também a aplicação de sobrecargas, tal como mostrado na Figura 44. Devido a estes equipamentos foi possível ensaiar todos os materiais simultaneamente.

Estes dessecadores apesar de terem características similares às dos edômetros não foram colocadas em prensas de adensamento por não serem disponíveis uma para cada amostra (4 prensas).

Três dessecadores foram utilizados para a imposição da sucção em amostras dos materiais 1, 2 e 4 com as soluções salinas saturadas e soluções salinas aquosas descritas anteriormente e um dessecador para a imposição de sucção equivalente a $1 \mathrm{MPa}$ (Lang, 1967), numa amostra do material 3. Em todos os casos, o processo foi de umedecimento, sendo que as amostras foram submetidas aos mesmos procedimentos indicados nos item 4.2.4.3.

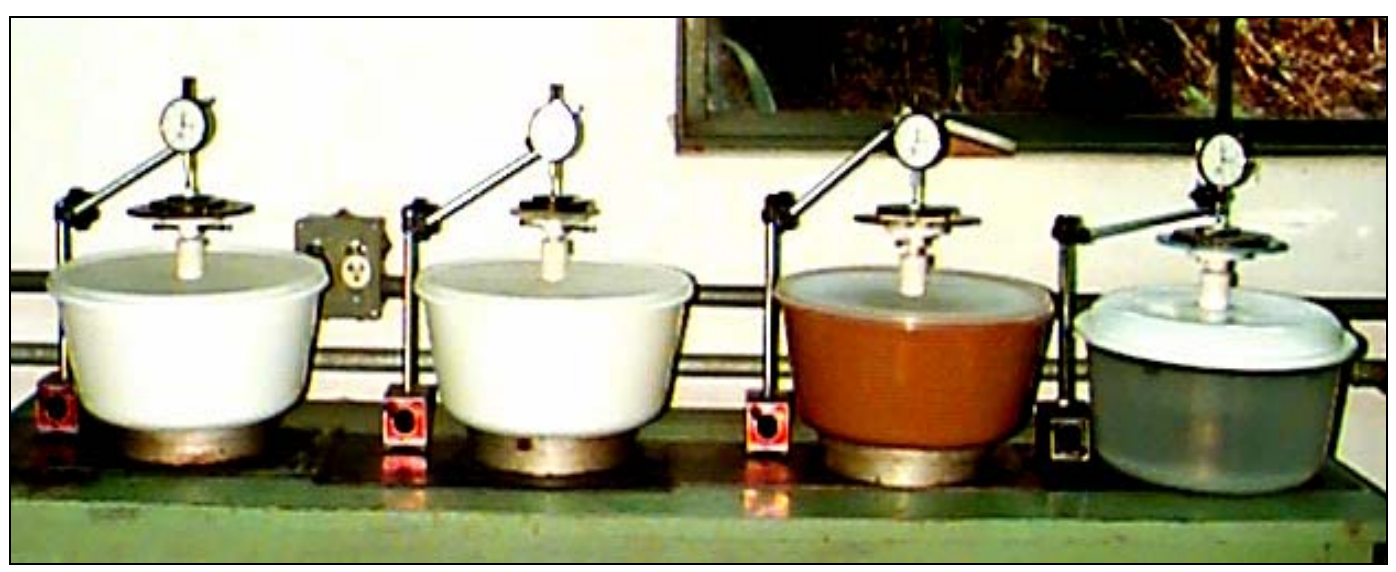

FIGURA 44. Dessecadores onde foram impostas as sucções nos materiais. 


\subsubsection{Ensaios de Adensamento}

Com o objetivo de determinar a tensão de pré-adensamento dos cinco materiais argilosos, foram realizados ensaios de adensamento para as amostras nas quais foram impostas sucções e submetidas aos ensaios de pressão de expansão a volume constante. Após o equilíbrio deformacional das amostras, iniciava-se o ensaio de adensamento.

Devido às altas pressões de expansão, as cargas necessárias para manter o ensaio a volume constante, chegaram muito próximas às limitações da prensa utilizada, portanto, não foi possível a realização deste ensaio para as amostras dos materiais $2,3 \mathrm{e}$ 4, nas quais foram impostas sucção através de $\mathrm{NaCl}$ saturado (40 $\mathrm{MPa})$; para os materiais 2 e 3 , nas quais foram impostas sucção a partir de $\mathrm{KCl}$ saturado (24MPa) e para o material 2 no qual foi imposta sucção através de Cloreto de bário saturado (15MPa). Todas as amostras nas quais foram impostas sucção através de $\mathrm{NaCl}$ com concentração para gerar sucções de 5, 3 e $1 \mathrm{MPa}$, puderam ser submetidas a este ensaio. Os ensaios foram conduzidos em estágios de cerca de 4, 11, 23, 48, 101, 202, 404, 800, 1600 e 2340 a $3200 \mathrm{kPa}$. Todos os estágios dos ensaios foram mantidos até a estabilização da deformação para cada carregamento, que foi geralmente de 24 horas. Esse período mostrou-se suficiente para o desenvolvimento do adensamento dos corpos de prova. As leituras da variação de altura foram efetuadas no extensômetro, nos tempos de 4s, 15s, 1min., 2min., 4min., 6min., 9min., 12min., 16min., 25min., 36min., 49min., 1:04h, 1:40h, 2h, 4h, 8h e 24 h após a aplicação de cada carga. Os resultados são dados em gráficos de relação índice de vazios (e/e $\mathrm{e}_{\mathrm{o}}$, onde, $\mathrm{e}_{\mathrm{o}}$ é índice de vazios inicial da amostra) versus logaritmo da tensão aplicada $(\sigma$ em $\mathrm{kPa})$. As tensões de pré adensamento foram determinadas a partir da proposta de Pacheco Silva (1971). 


\section{CAPÍTULO 5. APRESENTAÇÃO E ANÁlISE DOS RESULTADOS}

\subsection{Ensaios de Caracterização}

\subsubsection{Análise Granulométrica, Índices Físicos e Limites de Consistência}

As curvas de distribuição granulométrica dos cinco materiais ensaiados estão representadas na Figura 45. Na Tabela 08, são mostradas as características dos materiais empregados neste trabalho, os índices físicos e limites de consistência, e também a classificação dos mesmos, segundo a escala da Associação Brasileira de Normas Técnicas (ABNT: 7181/84), Sistema Unificado de Classificação de Solos (SUCS) (Nogueira, 1988) e HRB (Highway Research Board) (Bueno e Vilar, 1995).

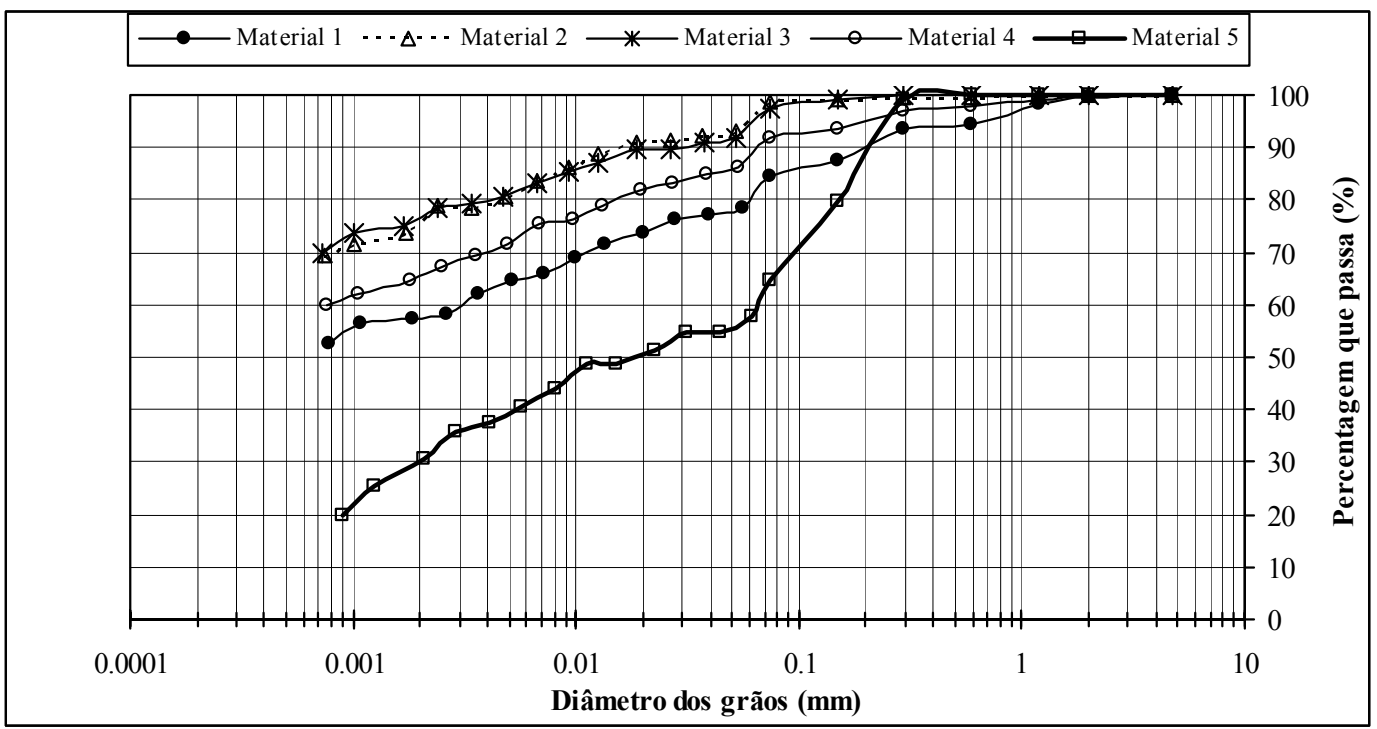

FIGURA 45. Curvas de distribuição granulométrica dos cinco materiais analisados. 
TABELA 08. Características geotécnicas dos materiais

\begin{tabular}{cccccc}
\hline $\begin{array}{c}\text { Características } \\
\text { Geotécnicas }\end{array}$ & Material 1 & Material 2 & Material 3 & Material 4 & Material 5 \\
\hline$\%$ argila & 58,0 & 75,0 & 78,0 & 67,0 & 30,0 \\
$\%$ silte & 26,7 & 23,6 & 19,6 & 24,8 & 34,6 \\
$\%$ areia & 15,3 & 1,4 & 2,4 & 8,2 & 35,4 \\
w (\%) & 36,0 & 41,4 & 36,9 & 51,0 & 24,4 \\
$\rho_{\mathrm{s}}\left(\mathrm{g} / \mathrm{cm}^{3}\right)$ & 2,682 & 2,676 & 2,699 & 2,674 & 2,653 \\
$\rho\left(\mathrm{g} / \mathrm{cm}^{3}\right)$ & 1,701 & 1,654 & 1,672 & 1,576 & 1,865 \\
$\rho_{\mathrm{d}}\left(\mathrm{g} / \mathrm{cm}^{3}\right)$ & 1,251 & 1,170 & 1,221 & 1,044 & 1,499 \\
$\mathrm{e}$ & 1,144 & 1,287 & 1,210 & 1,562 & 0,770 \\
$n(\%)$ & 53,4 & 56,3 & 54,8 & 61,0 & 43,5 \\
Sr (\%) & 84,4 & 86,1 & 82,3 & 87,3 & 84,1 \\
LL $(\%)$ & 86,0 & 100,0 & 81,0 & 83,0 & 42,0 \\
LP (\%) & 31,5 & 44,5 & 41,6 & 35,4 & 23,9 \\
IP (\%) & 54,5 & 55,5 & 39,4 & 47,6 & 18,1 \\
Classificação & Argila & Argila & Argila & Argila & Areia \\
Granulométrica & siltosa & siltosa & siltosa & siltosa & silto- \\
(ABNT) & & & & & argilosa \\
SUCS & CH & MH & MH & CH & CL \\
HRB & A-7 & A-7 & A-7 & A-7 & A-7 \\
\hline & & & & & \\
\hline
\end{tabular}

Como pode ser observado na Tabela 08 , os materiais possuem teores de argila elevados, com exceção do material 5 , todos apresentam mais de $50 \%$ da fração argila. Quanto à textura, a maioria dos materiais são argilas siltosas (exceto o material 5) segundo a classificação da ABNT. A classificação da HRB mostra que em todos os casos trata-se de argilas plásticas e finalmente a classificação SUCS indica que os materiais 1 e 4 são argilas muito plásticas, os materiais 2 e 3 siltes plásticos e o material 5 uma argila pouco plástica.

Os índices físicos mostram que os materiais possuem um grau de saturação elevado (superior a $80 \%$ ) e para a maioria dos materiais um índice de vazios alto, superior a 1. Os limites de liquidez e de plasticidade também são altos, indicando valores característicos de materiais argilosos. 


\subsubsection{Análise Térmica Diferencial (ATD)}

Na Figura 46, são mostrados os termogramas obtidos para os materiais estudados, provenientes das análises térmicas diferencial (ATD).

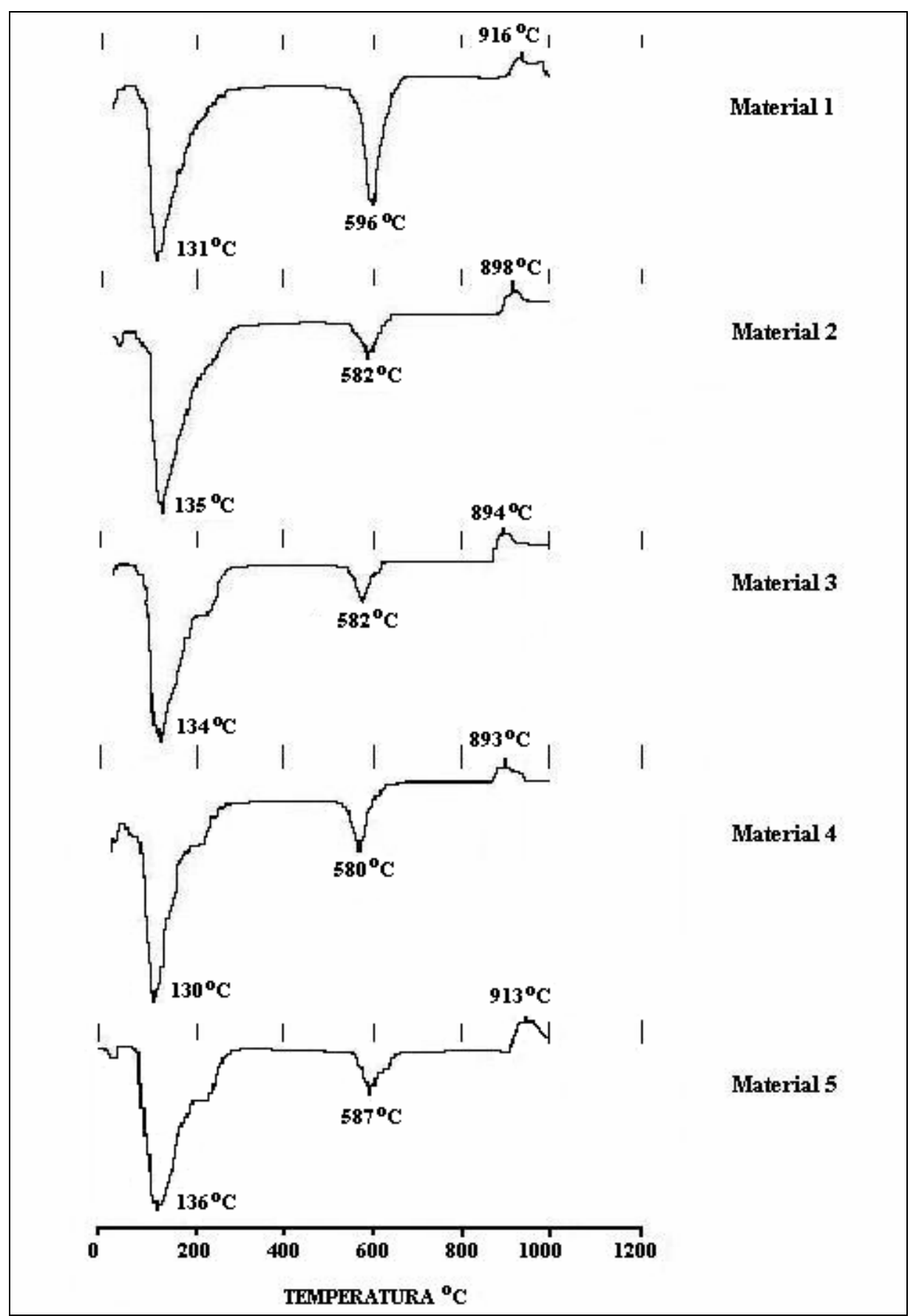

FIGURA 46. Termogramas obtidos para os materiais argilosos. 
A partir dos registros obtidos nos termogramas (Figura 46), pôde-se detectar a presença de argilominerais do grupo da esmectita, e provavelmente caulinita, através de picos característicos.

Em todos os materiais, o primeiro pico endotérmico é de grande intensidade e ocorre numa faixa de aproximadamente 130 a $136^{\circ} \mathrm{C}$, evidenciando a perda de água adsorvida. Nos materiais 1 e 2 ocorre um pico único, indicando argilominerais montmoriloníticos sódicos (Santos, 1989). A presença de $\mathrm{Ca}^{++}$e $\mathrm{Mg}^{++}$, impõem um caráter assimétrico aos picos nesta faixa de temperatura, nas amostras dos materiais 3,4 e 5, sendo estes picos devido à água adsorvida intercalada entre as camadas e a água coordenada aos cátions trocáveis. Também ocorre um segundo pico endotérmico próximo a $600^{\circ} \mathrm{C}$ que representa a perda de hidroxilas estruturais, que pode caracterizar o grupo da caulinita. Um outro pico ocorre próximo a $900^{\circ} \mathrm{C}$, indicando provavelmente a nucleação de mulita (Santos, 1989).

\subsubsection{Análise Térmica Gravimétrica (ATG)}

Na Tabela 09 e nas Figuras 47, 48, 49, 50 e 51, podem ser observados os resultados das análises termogravimétricas para os cinco materiais ensaiados.

TABELA 09. Dados obtidos nos ensaios de ATG

\begin{tabular}{ccccc}
\hline Material & $\begin{array}{c}\text { Temperatura } \\
\left({ }^{\mathbf{0}} \mathbf{C}\right)\end{array}$ & $\begin{array}{c}\text { Pontos Críticos } \\
\text { (Limites considerados) }\end{array}$ & $\begin{array}{c}\text { Perda de massa } \\
(\mathbf{\%})\end{array}$ & $\begin{array}{c}\text { Perda de massa total } \\
\mathbf{( \% )}\end{array}$ \\
\hline 1 & 126 & $20-350$ & 9,72 & 16,33 \\
& 569 & $356-787$ & 6,42 & 15,61 \\
\hline 2 & 128 & $24-376$ & 11,73 & 13,94 \\
& 536 & $376-697$ & 3,42 & 11,03 \\
\hline 3 & 140 & $32-364$ & 10,14 & \\
\hline 4 & 535 & $364-867$ & 3,62 & 17,52 \\
& 125 & $23-343$ & 7,90 & \\
\hline 5 & 519 & $343-744$ & 2,76 & 12,89 \\
& 147 & $22-383$ & 4,74 & \\
\hline
\end{tabular}




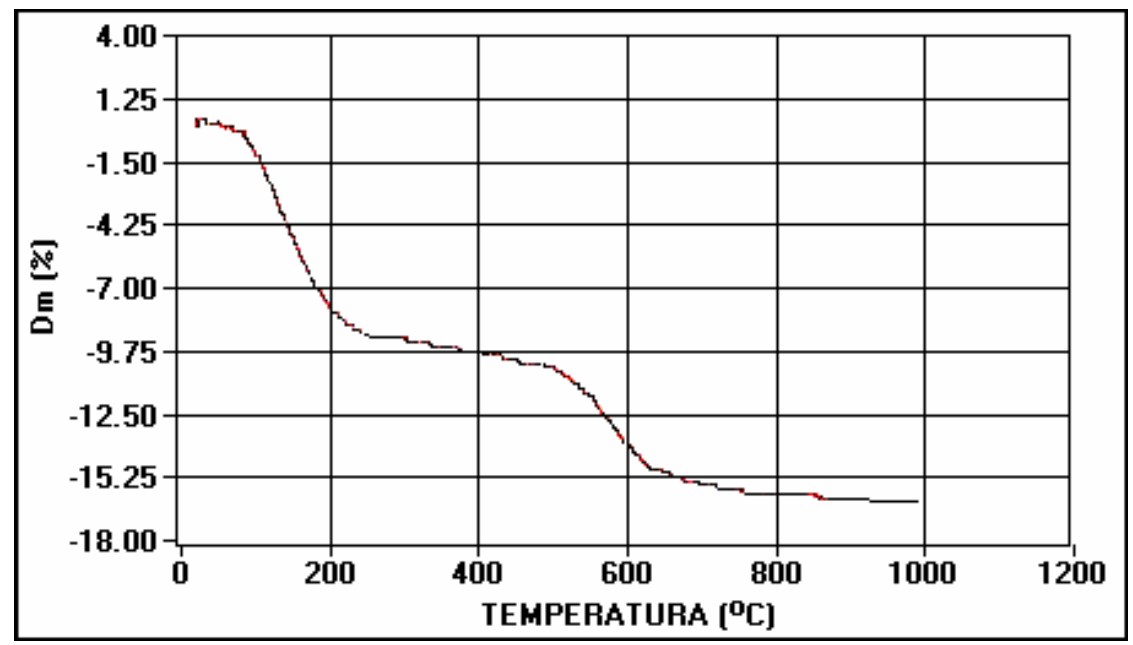

FIGURA 47. Representação da curva termogravimétrica para o material 1.

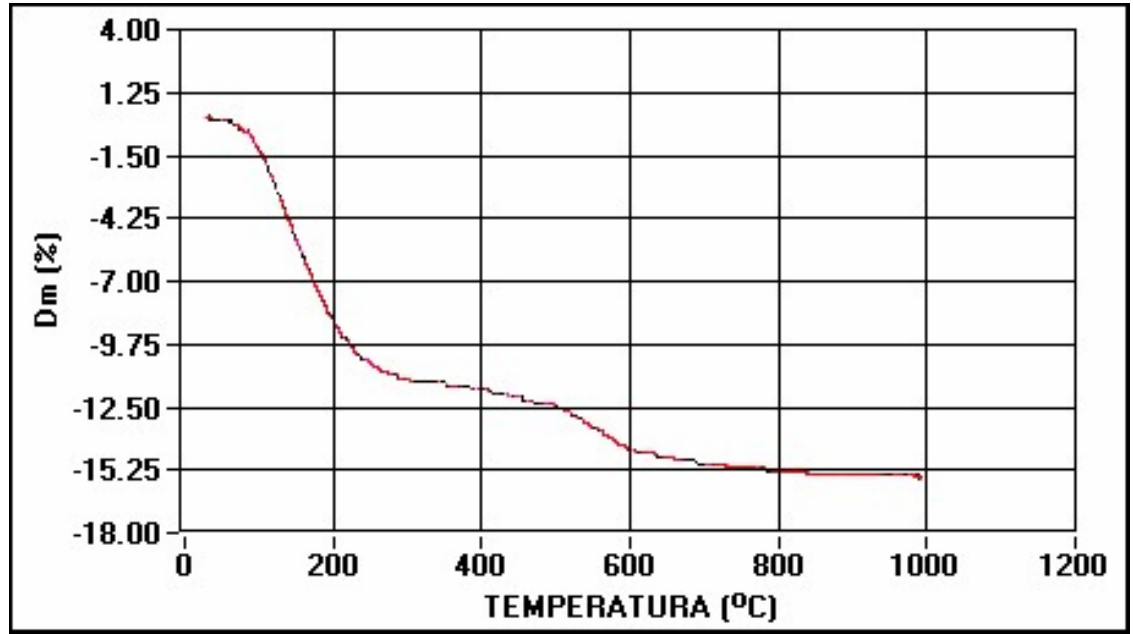

FIGURA 48. Representação da curva termogravimétrica para o material 2.

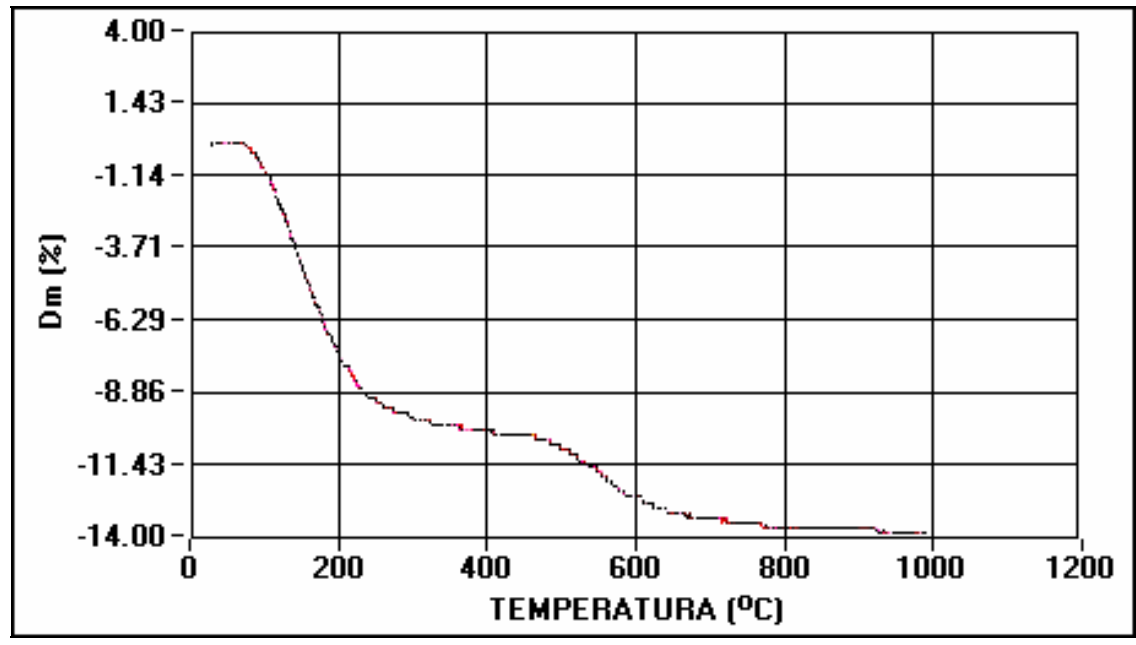

FIGURA 49. Representação da curva termogravimétrica para o material 3. 


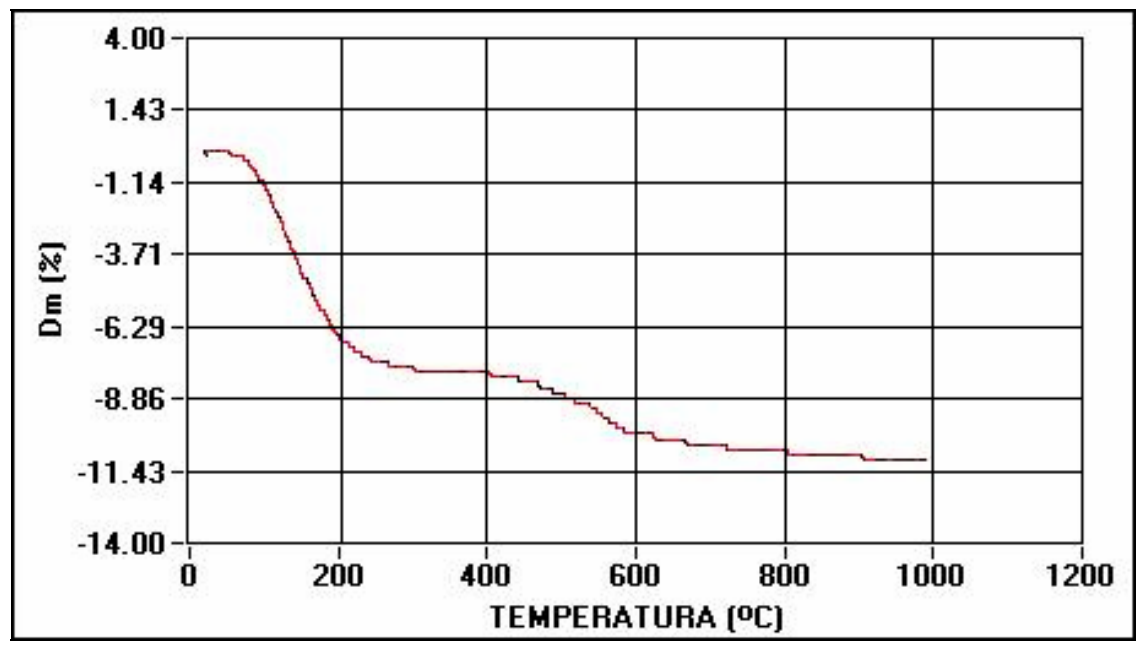

FIGURA 50. Representação da curva termogravimétrica para o material 4.

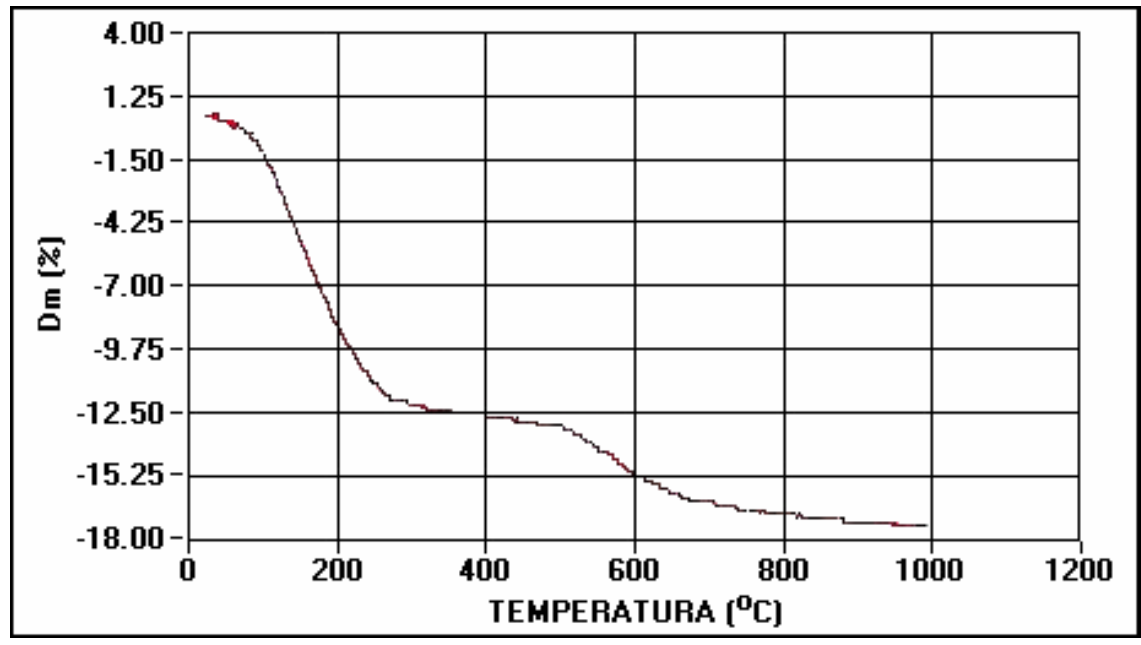

FIGURA 51. Representação da curva termogravimétrica para o material 5.

As informações da análise termogravimétrica (Figuras 47 a 51), confirmam os resultados obtidos no ATD. Em todas as amostras observou-se uma importante perda de massa (em torno de $10 \%$ ) por volta da temperatura de $130^{\circ} \mathrm{C}$, indicando a perda de água de hidratação, característica de argilominerais do grupo das esmectitas. O outro evento térmico, por volta de $550^{\circ} \mathrm{C}$, mostrou em todas as amostras uma perda de massa de 3 a $6 \%$, correspondente a perda de hidroxilas estruturais. 


\subsubsection{Difração de Raios-X}

Os registros dos difratogramas de Raios-X são representados nas Figuras 52, 53, 54,55 e 56.

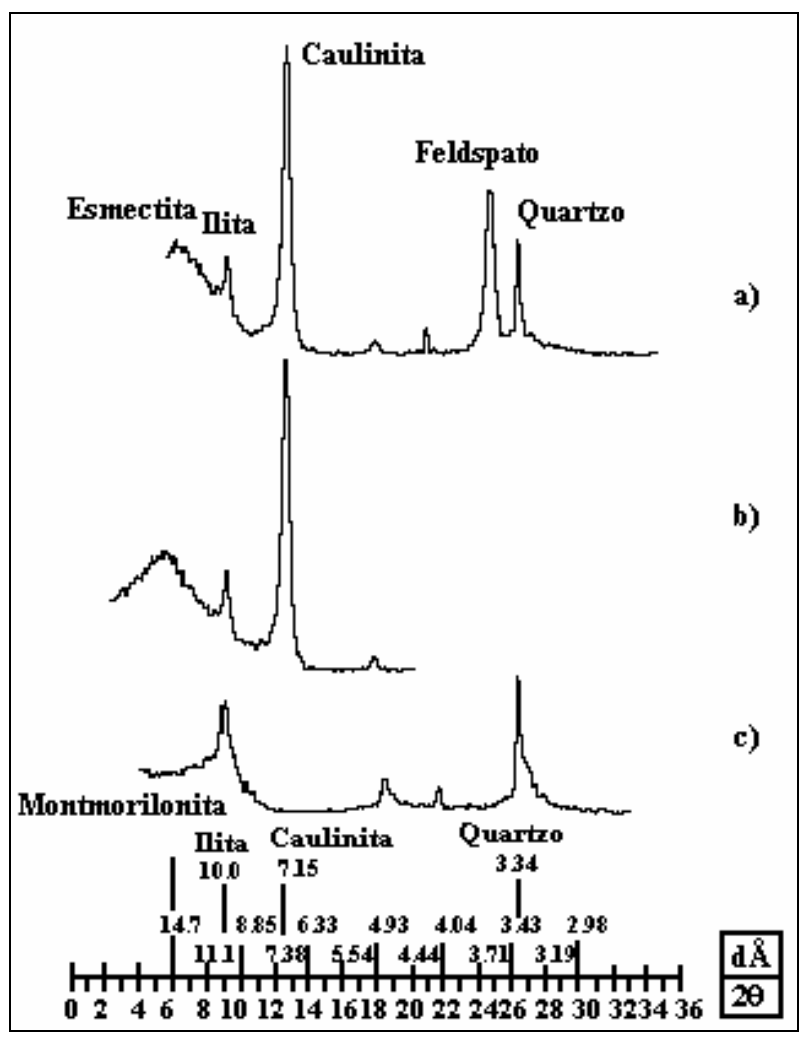

FIGURA 52. Representação dos difratogramas obtidos para o material 1: a) normal; b) etilenoglicol e c) aquecido a $550^{\circ} \mathrm{C}$. 


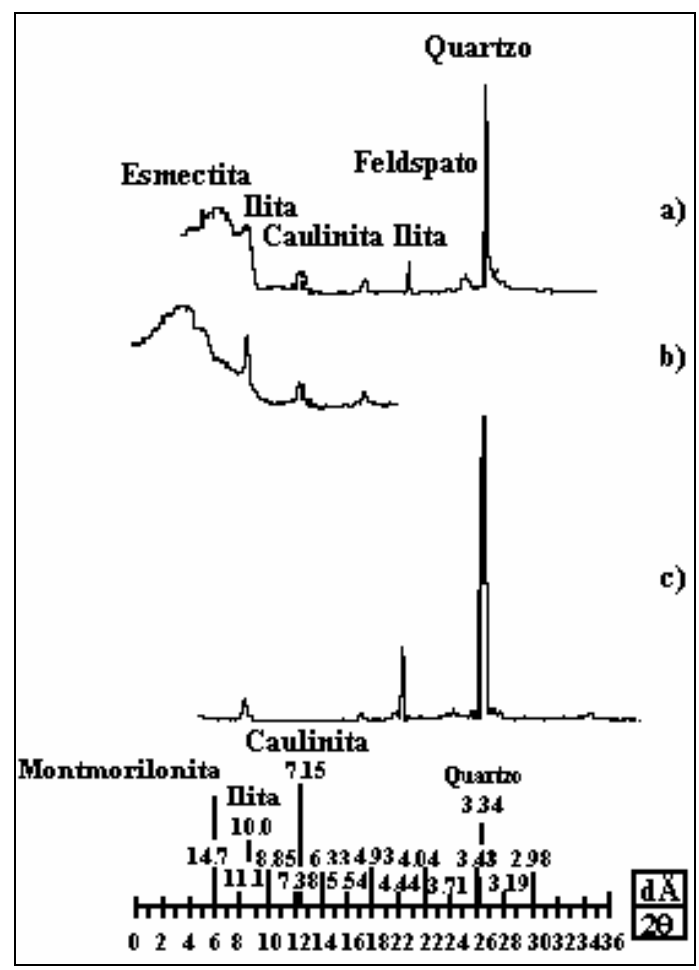

FIGURA 53. Representação dos difratogramas obtidos para o material 2: a) normal; b) etilenoglicol e c) aquecido a $550^{\circ} \mathrm{C}$.

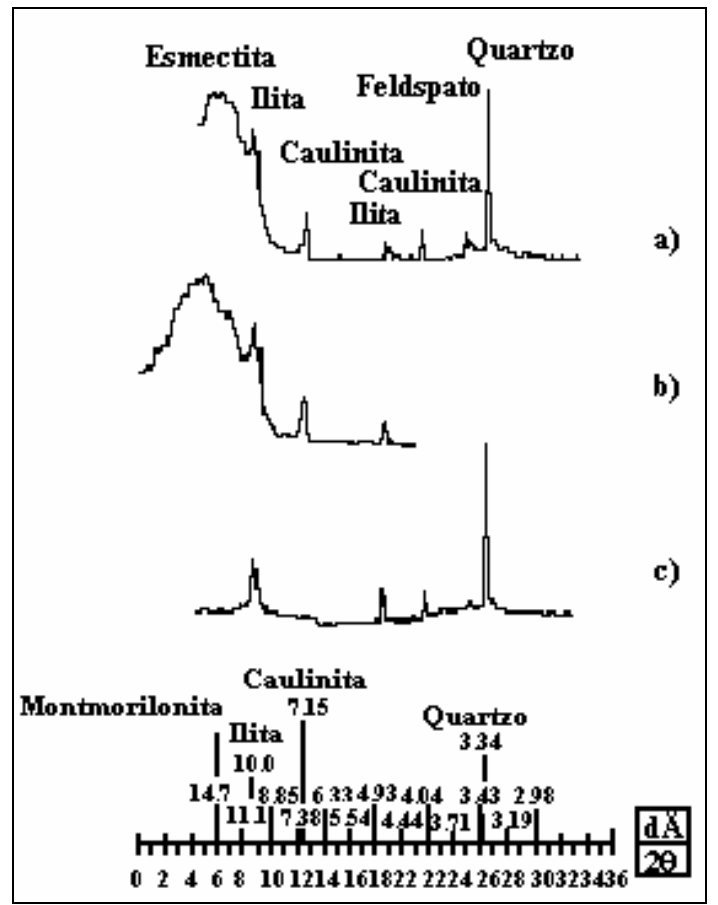

FIGURA 54. Representação dos difratogramas obtidos para o material 3: a) normal; b) etilenoglicol e c) aquecido a $550^{\circ} \mathrm{C}$. 


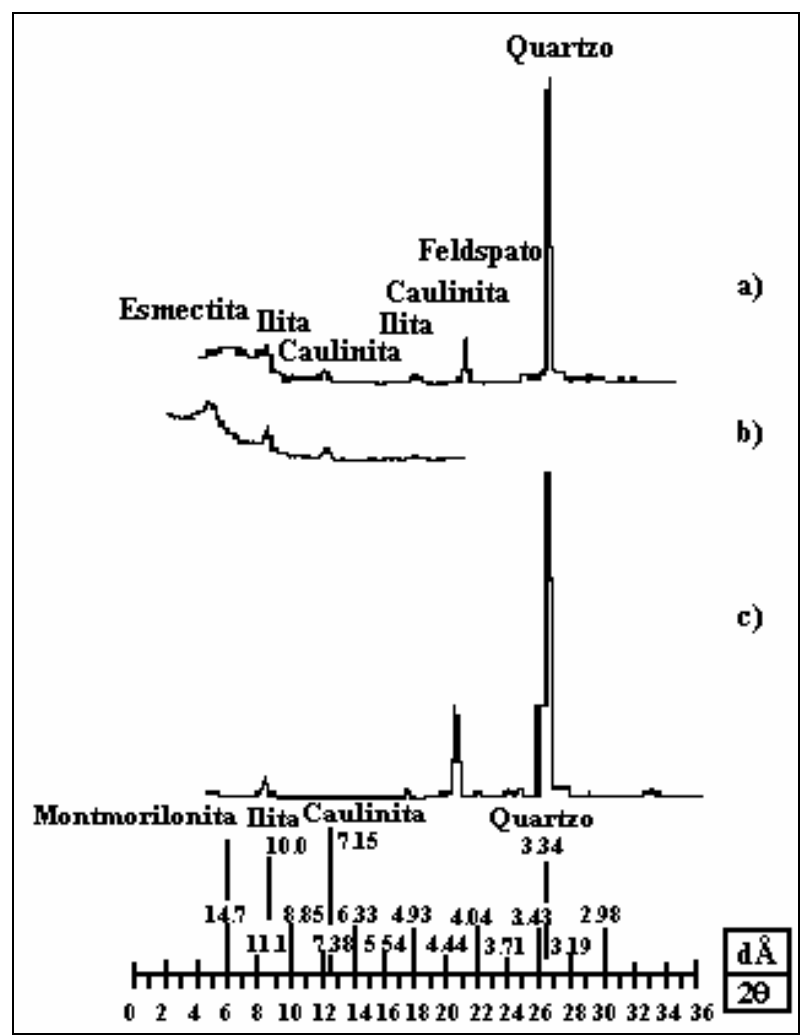

FIGURA 55. Representação dos difratogramas obtidos para o material 4: a) normal; b) etilenoglicol e c) aquecido a $550^{\circ} \mathrm{C}$.

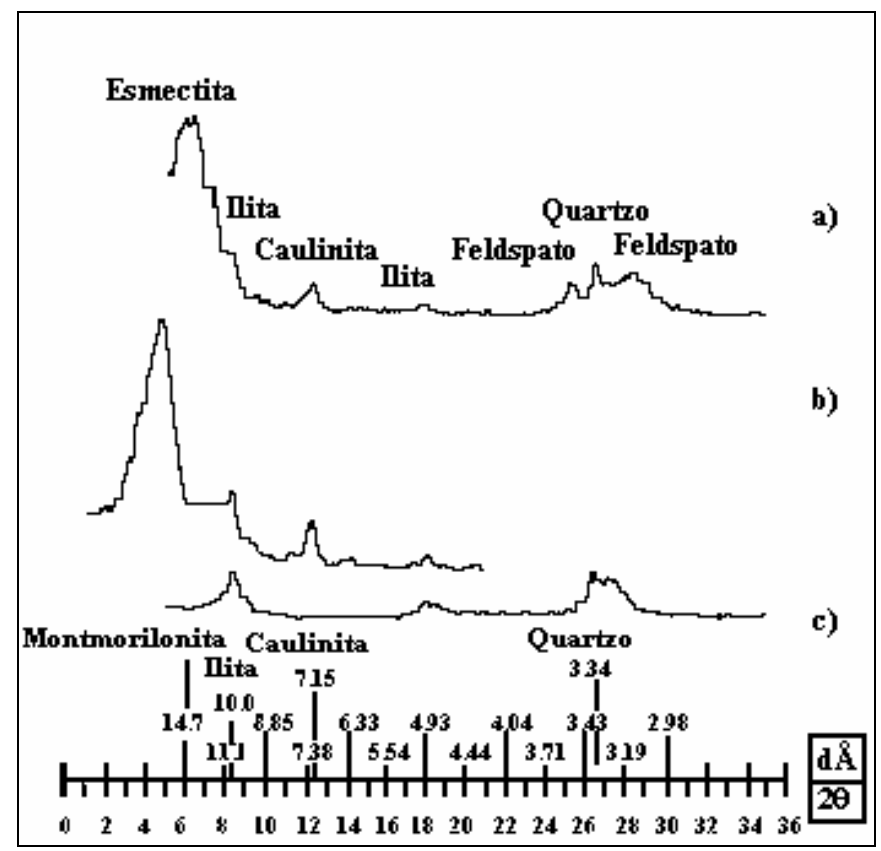

FIGURA 56. Representação dos difratogramas obtidos para o material 5: a) normal; b) etilenoglicol e c) aquecido a $550^{\circ} \mathrm{C}$. 
Os registros dos difratogramas de Raios-X (Figuras 52 a 56) indicam, em todos os materiais, a presença de argilominerais dos grupos da esmectita, das micas (ilita) e da caulinita, demonstrando a mistura de argilominerais que possui o material. Nas Figuras 52 a 56, estão marcadas as posições em que deveriam existir os picos da montmorilonita, ilita, caulinita e quartzo (Santos, 1989). De acordo com o mesmo autor, as variações que ocorrem no caso de misturas são devidas a alguns fatores como às diferentes proporções dos argilominerais identificados e granulometria muito fina, dificultando a orientação preferencial. A partir dos registros obtidos foi possível a realização de uma análise semiquantitativa comparativa para esses materiais, a fim de avaliar a porcentagem dos argilominerais que os compõem. $\mathrm{Na}$ Tabela 10, estão estimadas as porcentagens de cada um dos argilominerais presentes nos materiais, confirmando a presença de argilominerais expansivos, que é um dos fatores responsáveis pelos problemas geotécnicos que vêm ocorrendo na área de abrangência da Formação Guabirotuba.

É importante ressaltar, que apesar das percentagens encontradas na análise semiquantitativa, o comportamento expansivo dos materiais dependerá entre outros fatores, da quantidade total da fração argila contida em cada um deles.

TABELA 10. Análise semiquantitativa para os difratogramas de Raios - X

\begin{tabular}{cccccc}
\hline Material & Esmectita & Ilita & Caulinita & Quartzo & Feldspato \\
\hline 1 & $\mathrm{xx}$ & $\mathrm{xx}$ & $\mathrm{xxxx}$ & $\mathrm{xxx}$ & $\mathrm{xxx}$ \\
2 & $\mathrm{xx}$ & $\mathrm{xx}$ & $\mathrm{x}$ & $\mathrm{xxx}$ & $\mathrm{x}$ \\
3 & $\mathrm{xxx}$ & $\mathrm{xx}$ & $\mathrm{xx}$ & $\mathrm{xxx}$ & $\mathrm{xx}$ \\
4 & $\mathrm{x}$ & $\mathrm{x}$ & $\mathrm{xx}$ & $\mathrm{xxxx}$ & $\mathrm{x}$ \\
5 & $\mathrm{xxxx}$ & $\mathrm{x}$ & $\mathrm{x}$ & $\mathrm{x}$ & $\mathrm{xx}$
\end{tabular}

Onde: $\mathrm{x}=$ baixa porcentagem; $\mathrm{x}=$ média porcentagem; $\mathrm{xx}=$ alta porcentagem e $\mathrm{xxxx}=$ muito alta porcentagem.

\subsubsection{Adsorção de Azul de Metileno}

Estão representados nas Tabelas 11 e 12, os resultados de CTC, SE, VB e Acb, de todas as amostras dos cinco materiais que foram ensaiados para a determinação da pressão de expansão no edômetro convencional.

Estes ensaios tiveram como finalidade, verificar se cada material apresentava heterogeneidade quanto à quantidade de argilominerais do grupo da esmectita, em 
relação às amostras empregadas em cada um deles, já que os ensaios edométricos apresentaram resultados diferentes para teores de umidade muito próximos em cada material.

Com a finalidade de obter informação sobre a heterogeneidade ou homogeneidade dos resultados da CTC da argila (Tabelas 11 e 12), foram determinados os coeficientes de variação para as amostras de cada material. Dos resultados, se observou que para os materiais 1, 2, 3, 4 e 5 os coeficientes de variação foram 14,2; 5,3; 5,7; 14,1 e 9,1 \% respectivamente, demonstrando que os materiais 1 e 4 fornecem resultados mais heterogêneos seguido do material 5, e finalmente os materiais 3 e 2. Apesar de não se contar com valores de referência de resultados de CTC cuja dispersão seja caracterizada por este parâmetro e para estes tipos de materiais, se observou que eles não ultrapassam o 15\%, manifestando uma provável dispersão comumente encontrada nos ensaios geotécnicos (de 10 a 20\% segundo Lumb, 1968).

Quanto à maior heterogeneidade (materiais 1 e 4), talvez esteja relacionada com a maior variabilidade dos argilominerais mais ativos que compõem um mesmo material.

Com base em valores de CTC típicos de alguns tipos de argilominerais, tais como, a montmorilonita $\left(80-150 \mathrm{cmol}^{+} / \mathrm{Kg}\right)$ e ilita $\left(10-40 \mathrm{cmol}^{+} / \mathrm{Kg}\right)$, observa-se que os resultados para as amostras ensaiadas encaixam-se entre estes intervalos de valores, indicando a mistura dos grupos (Tabelas 11 e 12), conforme já verificado nas análises térmicas e na difração de raios-x. Os altos valores de CTC indicam o predomínio de argilominerais com alta capacidade de troca de cátions e superfície específica elevada.

Lautrin (1989), baseado em resultados de ensaios de adsorção de azul de metileno e na composição mineralógica das argilas, elaborou um diagrama, com valores de Acb e porcentagem de argila (\%), com a finalidade de caracterizar a atividade da fração fina dos solos e estimar sua composição. Segundo avaliação dos resultados de Acb e porcentagem da fração argila determinadas neste estudo (Tabelas 11 e 12), os materiais argilosos da Formação Guabirotuba, são classificados de acordo com a proposta de Lautrin (1989), como muito ativos a nocivos.

Os valores do índice VB, como mostrado em Pereira e Pejon (1999), podem ser utilizados como um indicativo da atividade da fração argila do material e conseqüentemente do seu potencial expansivo. 
TABELA 11. Resultados dos Ensaios de Adsorção de Azul de Metileno para as amostras dos materiais 1, 2 e 3

\begin{tabular}{|c|c|c|c|c|c|c|c|c|}
\hline Material & Descrição & $\begin{array}{c}\text { Argila } \\
(\%) \\
\end{array}$ & $\begin{array}{c}\mathrm{CTC} \\
\mathrm{cmol}^{+} / \mathrm{Kg} \\
(\text { solo })\end{array}$ & $\begin{array}{c}\mathrm{CTC} \\
\mathrm{cmol}^{+} / \mathrm{Kg} \\
\text { (argila) } \\
\end{array}$ & $\begin{array}{c}\mathrm{SE} \\
\mathrm{m}^{2} / \mathrm{g} \text { (solo) }\end{array}$ & $\begin{array}{c}\mathrm{SE} \\
\mathrm{m}^{2} / \mathrm{g} \text { (argila) }\end{array}$ & $\begin{array}{c}\text { VB } \\
(\mathrm{g} / 100 \mathrm{~g} \text { de solo })\end{array}$ & $\begin{array}{c}\text { Acb } \\
\text { (g/100g de argila) }\end{array}$ \\
\hline \multirow[t]{8}{*}{1} & Amostra seca ao ar & 58 & 29,35 & 50,61 & 229,73 & 396,09 & 9,39 & 16,19 \\
\hline & Amostra com umidade natural & 58 & 25,23 & 43,50 & 197,46 & 340,44 & 8,07 & 13,91 \\
\hline & Sucção imposta por $\mathrm{NaCl}$ saturado & 58 & 30,33 & 52,30 & 237,43 & 409,36 & 9,70 & 16,73 \\
\hline & Sucção imposta por $\mathrm{KCl}$ saturado & 58 & 25,37 & 43,74 & 198,57 & 342,36 & 8,12 & 13,99 \\
\hline & Sucção imposta porBaCl $\mathrm{Ba}_{2} \cdot 2 \mathrm{H}_{2} \mathrm{O}$ saturado & 58 & 29,15 & 50,26 & 228,16 & 393,37 & 9,33 & 16,08 \\
\hline & Sucção imposta por $\mathrm{NaCl}-5 \mathrm{MPa}$ & 58 & 38,65 & 66,63 & 302,48 & 521,51 & 12,36 & 21,32 \\
\hline & Sucção imposta por $\mathrm{NaCl}-3 \mathrm{MPa}$ & 58 & 31,63 & 54,53 & 247,53 & 426,78 & 10,12 & 17,44 \\
\hline & Sucção imposta por $\mathrm{NaCl}-1 \mathrm{MPa}$ & 58 & 32,51 & 56,05 & 254,45 & 438,51 & 10,40 & 17,93 \\
\hline \multirow[t]{8}{*}{2} & Amostra seca ao ar & 75 & 59,29 & 79,06 & 464,08 & 618,77 & 18,97 & 25,29 \\
\hline & Amostra com umidade natural & 75 & 54,46 & 72,61 & 426,24 & 568,31 & 17,42 & 23,23 \\
\hline & Sucção imposta por $\mathrm{NaCl}$ saturado & 75 & 52,51 & 70,01 & 410,97 & 547,96 & 16,80 & 22,40 \\
\hline & Sucção imposta por $\mathrm{KCl}$ saturado & 75 & 55,37 & 73,82 & 433,37 & 577,83 & 17,71 & 23,62 \\
\hline & Sucção imposta porBaCl${ }_{2} \cdot 2 \mathrm{H}_{2} \mathrm{O}$ saturado & 75 & 60,72 & 80,95 & 475,22 & 633,62 & 19,42 & 25,90 \\
\hline & Sucção imposta por $\mathrm{NaCl}-5 \mathrm{MPa}$ & 75 & 53,46 & 71,28 & 418,46 & 557,95 & 17,10 & 22,80 \\
\hline & Sucção imposta por $\mathrm{NaCl}-3 \mathrm{MPa}$ & 75 & 58,95 & 78,60 & 461,39 & 615,18 & 18,86 & 25,14 \\
\hline & Sucção imposta por $\mathrm{NaCl}-1 \mathrm{MPa}$ & 75 & 57,28 & 76,37 & 448,34 & 597,79 & 18,32 & 24,43 \\
\hline \multirow[t]{8}{*}{3} & Amostra seca ao ar & 78 & 55,98 & 71,77 & 438,19 & 561,78 & 17,91 & 22,96 \\
\hline & Amostra com umidade natural & 78 & 51,53 & 66,07 & 403,33 & 517,09 & 16,48 & 21,13 \\
\hline & Sucção imposta por $\mathrm{NaCl}$ saturado & 78 & 59,98 & 76,89 & 469,44 & 601,85 & 19,19 & 24,60 \\
\hline & Sucção imposta por $\mathrm{KCl}$ saturado & 78 & 56,09 & 71,91 & 439,03 & 562,85 & 17,94 & 23,00 \\
\hline & Sucção imposta por $\mathrm{BaCl}_{2} \cdot 2 \mathrm{H}_{2} \mathrm{O}$ saturado & 78 & 61,26 & 78,54 & 479,46 & 614,70 & 19,60 & 25,12 \\
\hline & Sucção imposta por $\mathrm{NaCl}-5 \mathrm{MPa}$ & 78 & 54,68 & 70,11 & 428,02 & 548,74 & 17,49 & 22,43 \\
\hline & Sucção imposta por $\mathrm{NaCl}-3 \mathrm{MPa}$ & 78 & 55,42 & 71,05 & 433,79 & 556,15 & 17,73 & 22,73 \\
\hline & Sucção imposta por $\mathrm{NaCl}-1 \mathrm{MPa}$ & 78 & 53,46 & 68,54 & 418,46 & 536,49 & 17,10 & 21,93 \\
\hline
\end{tabular}


TABELA 12. Resultados dos Ensaios de Adsorção de Azul de Metileno para as amostras dos materiais 4 e 5

\begin{tabular}{|c|c|c|c|c|c|c|c|c|}
\hline Material & Descrição & $\begin{array}{c}\text { Argila } \\
(\%)\end{array}$ & $\begin{array}{c}\mathrm{CTC} \\
\mathrm{cmol}^{+} / \mathrm{Kg} \\
(\mathrm{solo})\end{array}$ & $\begin{array}{c}\mathrm{CTC} \\
\mathrm{cmol}^{+} / \mathrm{Kg} \\
\text { (argila) }\end{array}$ & $\begin{array}{c}\mathrm{SE} \\
\mathrm{m}^{2} / \mathrm{g} \text { (solo) }\end{array}$ & $\begin{array}{c}\mathrm{SE} \\
\mathrm{m}^{2} / \mathrm{g} \text { (argila) }\end{array}$ & $\begin{array}{c}\text { VB } \\
(\mathrm{g} / 100 \mathrm{~g} \text { de solo })\end{array}$ & $\begin{array}{c}\text { Acb } \\
(\mathrm{g} / 100 \mathrm{~g} \text { de argila })\end{array}$ \\
\hline \multirow[t]{9}{*}{4} & Amostra seca ao ar & 67 & 44,92 & 67,04 & 351,58 & 524,74 & 14,37 & 21,45 \\
\hline & Amostra com umidade natural & 67 & 47,74 & 71,25 & 373,63 & 557,65 & 15,27 & 22,79 \\
\hline & Sucção imposta por $\mathrm{NaCl}$ saturado & 67 & 33,65 & 50,22 & 263,37 & 393,09 & 10,76 & 16,07 \\
\hline & Sucção imposta por $\mathrm{KCl}$ saturado & 67 & 44,89 & 67,00 & 351,38 & 524,44 & 14,36 & 21,43 \\
\hline & Sucção imposta por $\mathrm{BaCl}_{2} \cdot 2 \mathrm{H}_{2} \mathrm{O}$ saturado & 67 & 46,59 & 69,54 & 364,68 & 544,30 & 14,91 & 22,25 \\
\hline & Sucção imposta por $\mathrm{NaCl}-5 \mathrm{MPa}$ & 67 & 48,25 & 72,02 & 377,68 & 563,70 & 15,44 & 23,04 \\
\hline & Sucção imposta por $\mathrm{NaCl}-3 \mathrm{MPa}$ & 67 & 55,68 & 83,11 & 435,83 & 650,49 & 17,81 & 26,59 \\
\hline & Sucção imposta por $\mathrm{NaCl}-1 \mathrm{MPa}$ & 67 & 44,07 & 65,78 & 344,94 & 514,83 & 14,10 & 21,04 \\
\hline & $\begin{array}{l}900 \mathrm{kPa} \text { de sucção - imposta no } \\
\text { Edômetro de translação de eixos }\end{array}$ & 67 & 37,52 & 56,00 & 293,66 & 438,29 & 12,00 & 17,91 \\
\hline \multirow[t]{8}{*}{5} & Amostra seca ao ar & 30 & 32,57 & 108,57 & 254,93 & 849,77 & 10,42 & 34,73 \\
\hline & Amostra com umidade natural & 30 & 27,46 & 91,54 & 214,94 & 716,48 & 8,79 & 29,28 \\
\hline & Sucção imposta por $\mathrm{NaCl}$ saturado & 30 & 30,56 & 101,87 & 239,19 & 797,30 & 9,78 & 32,59 \\
\hline & Sucção imposta por $\mathrm{KCl}$ saturado & 30 & 32,97 & 109,90 & 258,06 & 860,21 & 10,55 & 35,16 \\
\hline & Sucção imposta por $\mathrm{BaCl}_{2} 2 \mathrm{H}_{2} \mathrm{O}$ saturado & 30 & 29,51 & 98,38 & 231,01 & 770,04 & 9,44 & 31,47 \\
\hline & Sucção imposta por $\mathrm{NaCl}-5 \mathrm{MPa}$ & 30 & 36,42 & 121,39 & 285,04 & 950,13 & 11,65 & 38,83 \\
\hline & Sucção imposta por $\mathrm{NaCl}-3 \mathrm{MPa}$ & 30 & 28,71 & 95,70 & 224,72 & 749,05 & 9,18 & 30,62 \\
\hline & Sucção imposta por $\mathrm{NaCl}-1 \mathrm{MPa}$ & 30 & 30,34 & 101,14 & 237,48 & 791,59 & 9,71 & 32,35 \\
\hline
\end{tabular}




\subsubsection{Porosimetria por Intrusão de Mercúrio}

Os resultados dos ensaios de porosimetria por intrusão de mercúrio para amostras dos cinco materiais estão representados nos gráficos que serão mostrados a seguir, através das curvas de volume acumulado de mercúrio e diâmetro médio dos poros, curvas de diâmetro dos poros e logaritmo do volume diferencial de mercúrio e curvas de volume de poros acumulados e pressão absoluta aplicada (Figuras 57, 58, 59, 60, 61).

Cabe ressaltar que as curvas geradas para o material 1, apresentaram um resultado anômalo em relação aos demais, necessitando cautela quanto à interpretação das mesmas.

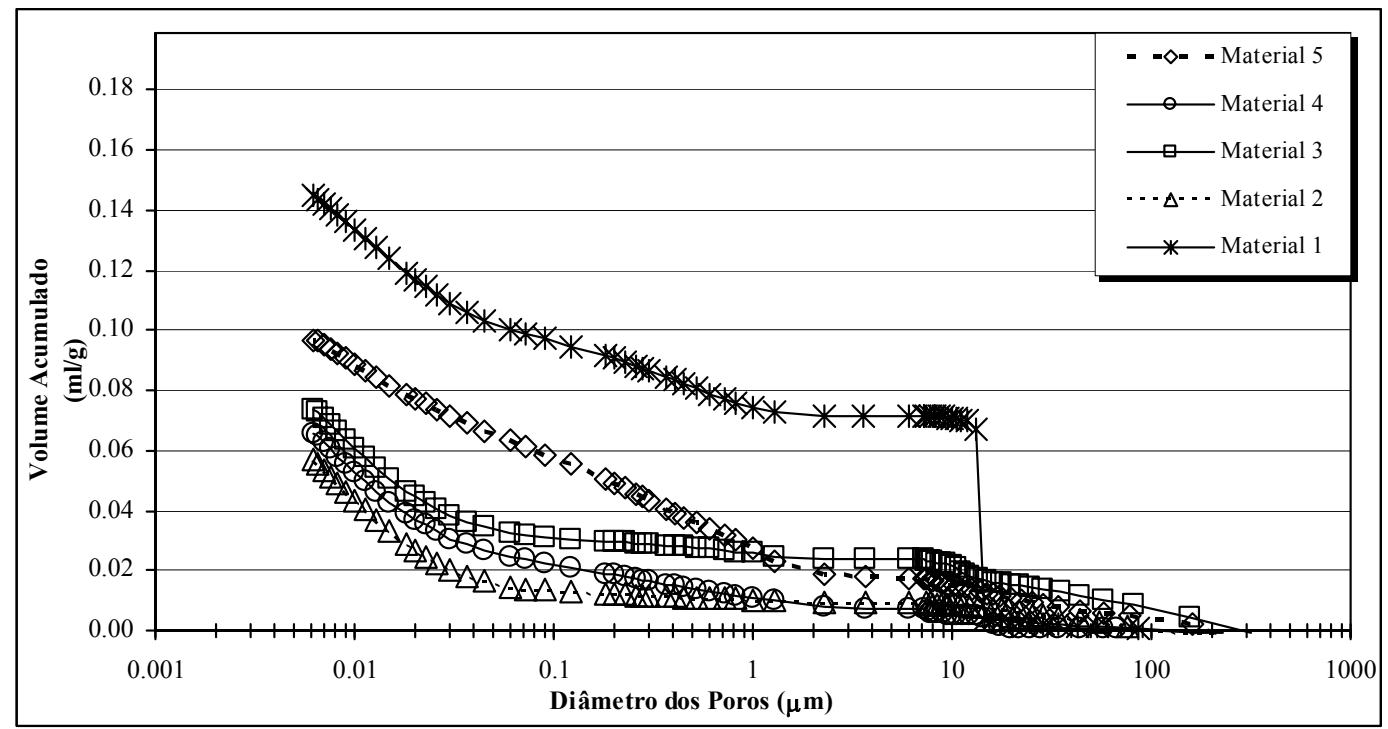

FIGURA 57. Distribuição do tamanho dos poros para os cinco materiais estudados.

Webb e Orr (1997) consideram poros menores que $20 \AA(0,002 \mu \mathrm{m})$ como microporos, de $20 \AA$ a $500 \AA$ como mesoporos e maiores que $500 \AA(0,05 \mu \mathrm{m})$ como macroporos.

Observa-se na Figura 57, que as amostras 1 e 5, apresentaram intrusão de maior volume de mercúrio na faixa de macroporos, da ordem de 0,1043 e $0,0673 \mathrm{ml} / \mathrm{g}$, respectivamente, enquanto que para as amostras 2,3 e 4 o volume de intrusão de mercúrio nos macroporos, foi da ordem de 0,0173, 0,0353 e 0,0278 ml/g, respectivamente. Pode-se observar a semelhança entre as curvas 2,3 e 4, que apresentam valores altos da fração argila (Tabela 08), se comparadas com as curvas dos 
materiais 1 e 5, que apresentam valores da fração areia de 15,3 e 35,4\% respectivamente.

Pode-se notar que nas curvas obtidas não são observados poros inferiores a 0,002 $\mu \mathrm{m}$, que caracterizariam os microporos dos materiais, devido à necessidade de pressões superiores (que excedem a capacidade do equipamento utilizado para o ensaio) para a introdução de mercúrio nestes poros.

$\mathrm{Na}$ Figura 58 representa-se a distribuição do tamanho dos poros em relação ao volume de mercúrio acumulado em termos percentuais (volume do mercúrio/ volume de vazios do solo).

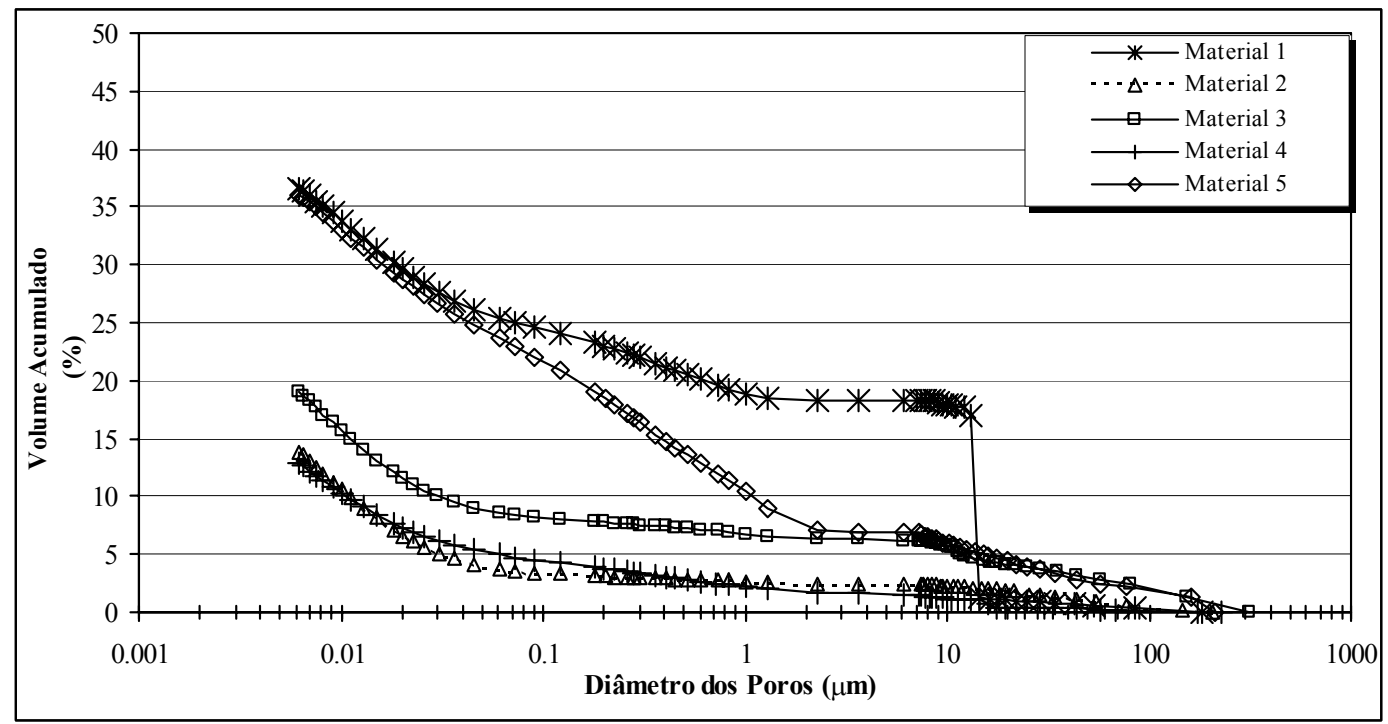

FIGURA 58. Distribuição do tamanho dos poros para os cinco materiais em termos percentuais.

A partir do gráfico da Figura 58, foi possível realizar uma estimativa da distribuição do tamanho dos poros nas amostras analisadas em termos percentuais, cujos resultados estão representados na Tabela 13.

TABELA 13. Estimativa da porcentagem de macroporos, mesoporos e microporos nas amostras analisadas para os cinco materiais

\begin{tabular}{cccccc}
\hline Material & 1 & 2 & 3 & 4 & 5 \\
\hline \% aproximada de macroporos & 26,2 & 4,1 & 9,0 & 5,3 & 24,8 \\
\% aproximada de microporos e mesoporos & 73,8 & 95,9 & 91,0 & 94,7 & 75,2 \\
\hline
\end{tabular}


Os materiais 2, 3 e 4 (Tabela 13) apresentam uma maior porcentagem de mesoporos e microporos em relação aos materiais 1 e 5 , característica relacionada com a maior porcentagem de argila desses materiais (Tabela 08).

O tamanho e distribuição dos poros são importantes na definição da sucção matricial do solo. Assim sendo, a partir da lei capilar pode-se estimar a sucção matricial que é dada a partir da expressão abaixo, admitindo-se que o ângulo de contato é zero (Ridley e Wray, 1996):

$\psi_{m}=\frac{2 \sigma_{s}}{r}$

Onde: $\sigma_{\mathrm{s}}=$ corresponde à tensão superficial da água, cujo valor é da ordem de $0,0149 \mathrm{kPa}$ para a temperatura de $20^{\circ} \mathrm{C}$, e $r=$ ao raio do poro $(\mathrm{cm})$.

Da expressão 25 se observa que a sucção do material aumenta com a redução do tamanho dos poros e isto deve ocorrer de igual forma com a porcentagem da fração argila, devido a que, nessa fração os espaços interpartículas são menores. Ambos os fatores, entre outros, como veremos mais adiante, devem favorecer a geração de uma maior pressão de expansão do material.

Admitindo a exeqüibilidade da equação 25 , pode-se relacionar os limites correspondentes ao tamanho dos poros segundo Webb e Orr (1997) com suas respectivas sucções. Disto resultou que, os macroporos (maiores que $0,05 \mu \mathrm{m}$ ) apresentam aproximadamente sucções matriciais inferiores a $298 \mathrm{kPa}$, os mesoporos $(0,002$ a $0,05 \mu \mathrm{m})$, sucções matriciais entre 298 e $7450 \mathrm{kPa}$ e os microporos (inferiores a $0,002 \mu \mathrm{m})$, valores de sucção matricial superiores a $7450 \mathrm{kPa}$.

Nas Figuras 59 e 60, estão representados os histogramas de freqüência das amostras dos cinco materiais argilosos. 


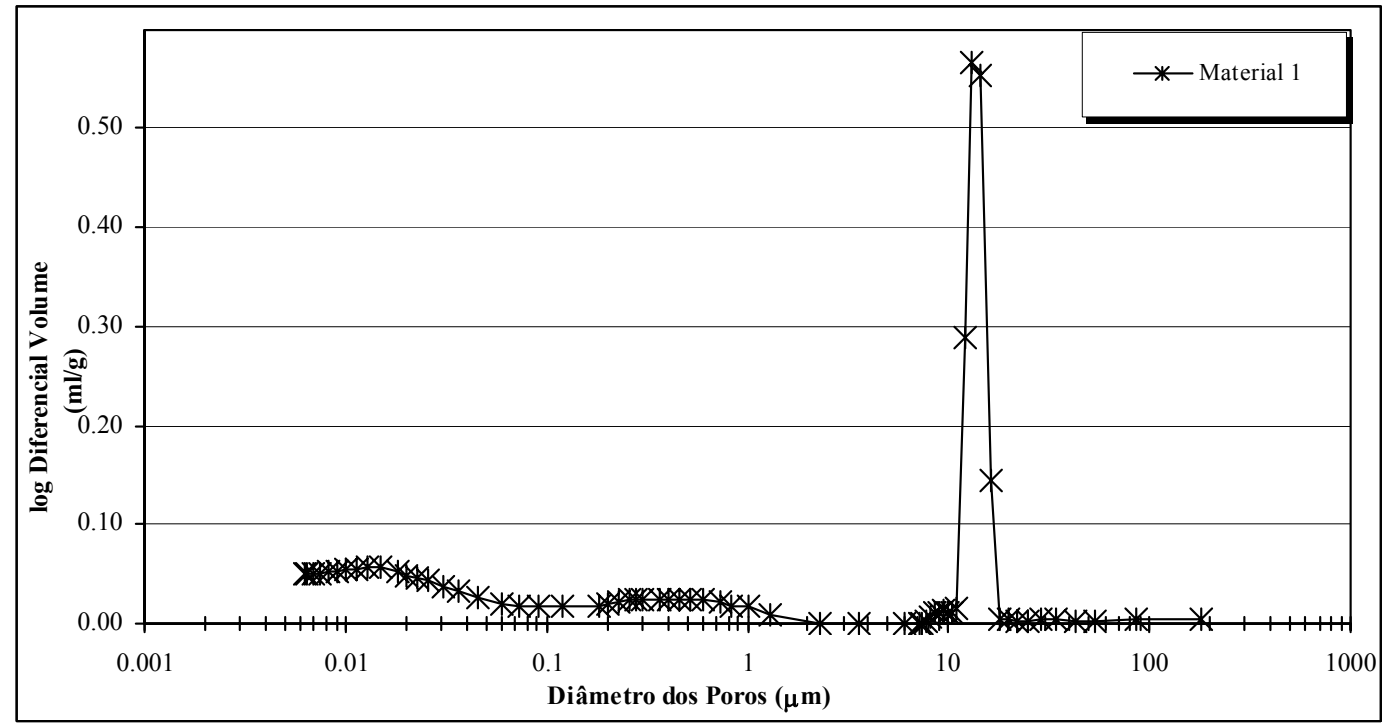

FIGURA 59. Diâmetro dos poros em função do Logaritmo do Volume Diferencial de Mercúrio introduzido na amostra do material 1.

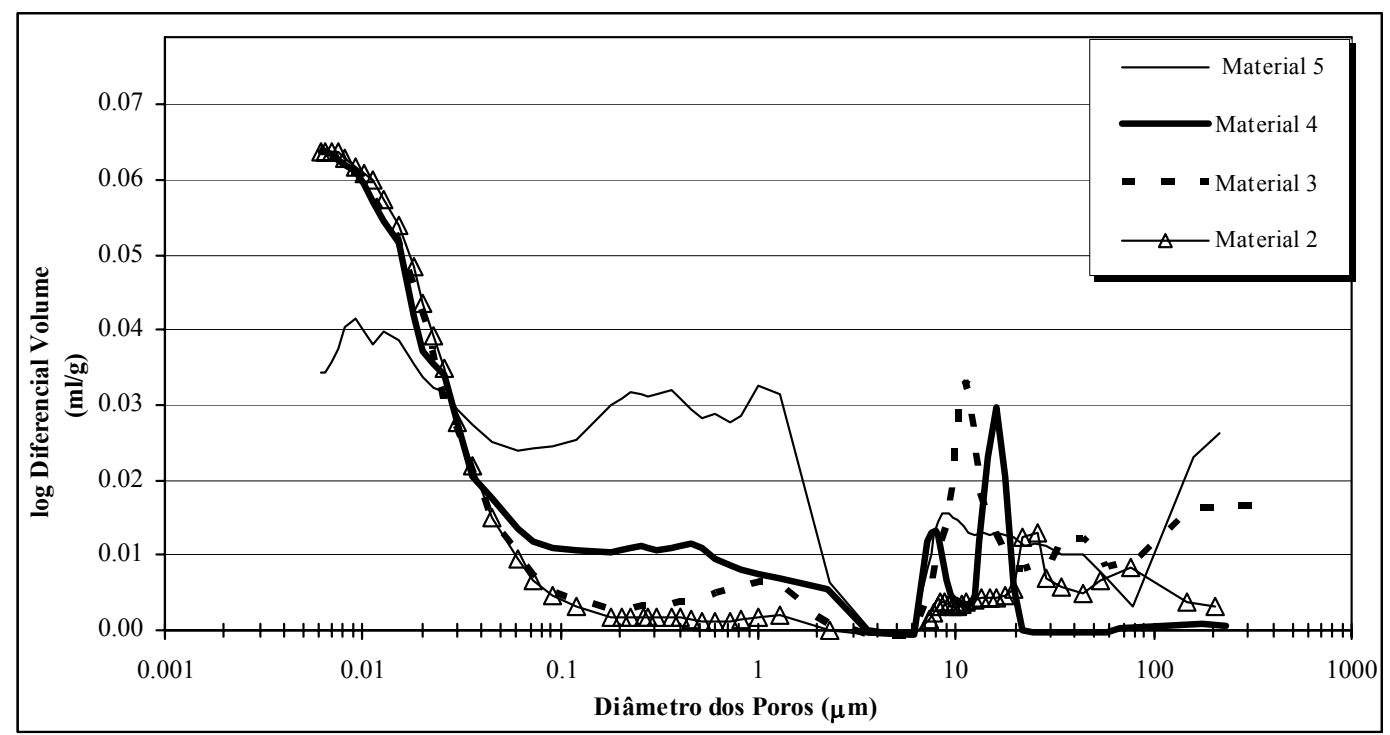

FIGURA 60. Diâmetro dos poros em função do Logaritmo do Volume Diferencial de Mercúrio introduzido nas amostras dos materiais 2, 3, 4 e 5.

O gráfico da Figura 60 mostra que para os materiais 2, 3 e 4 pode-se distinguir com mais clareza a concentração de mesoporos em relação aos macroporos. Já na amostra do material 5, não há uma distribuição bem definida do tamanho dos poros até as dimensões de poros medidos. 


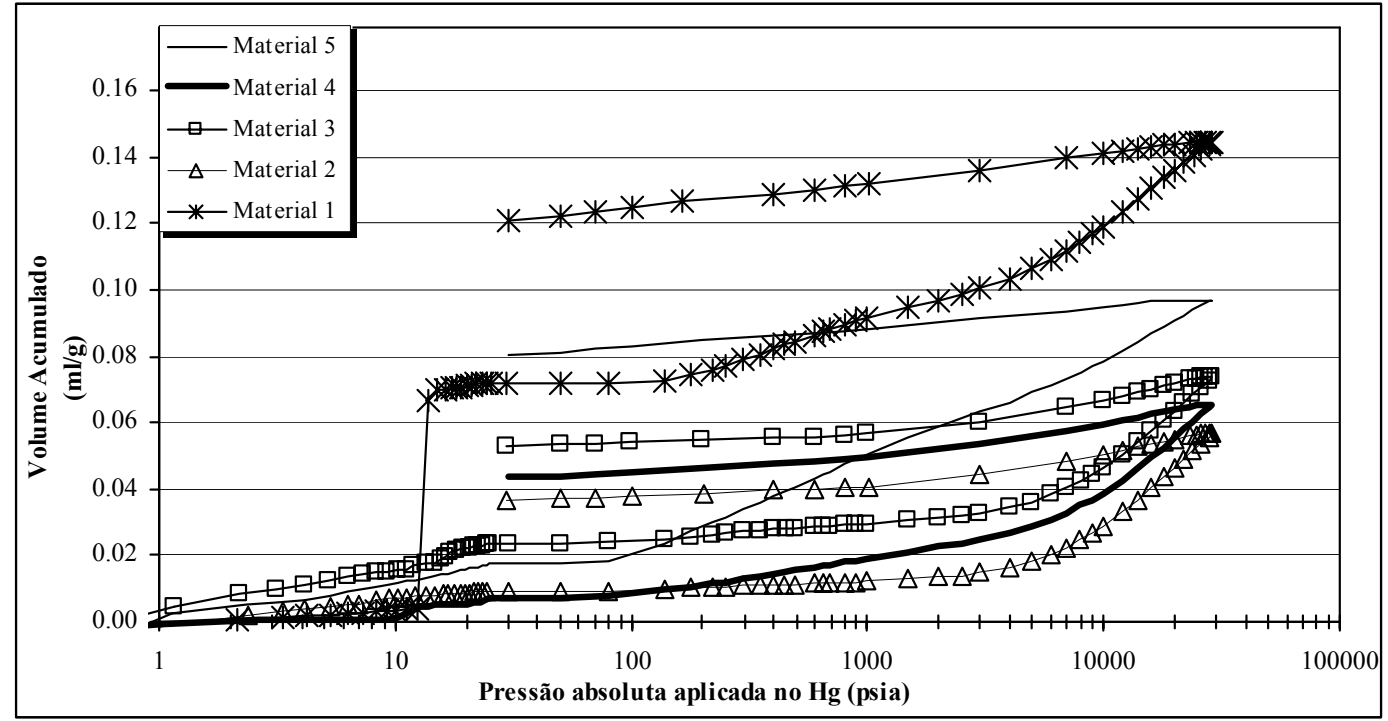

FIGURA 61. Curvas de Volume de Poros Acumulados em função da Pressão Absoluta Aplicada.

As curvas mostradas na Figura 61, representam a intrusão e a extrusão de mercúrio com a pressão aplicada. Observa-se que as curvas de intrusão não coincidem com as de extrusão, devido provavelmente, às formas irregulares dos poros no formato de garrafas ou pescoço, que impedem que seja extraído todo o mercúrio dos materiais no processo de extrusão.

\subsubsection{Microscopia Eletrônica de Varredura (MEV)}

As imagens obtidas para amostras dos cinco materiais através do MEV são mostradas nas Figuras 62 e 63 (material 1), 64 e 65 (material 2), 66 e 67 (material 3), 68 e 69 (material 4) e 70, 71 e 72 (material 5).

A Figura 62 mostra a composição mineralógica do material 1, onde podem ser observados argilominerais dos grupos da caulinita, ilita e esmectita, além de quartzo. Nota-se que os minerais não apresentam uma orientação preferencial. Na Figura 63, vêse detalhe da presença de argilominerais do grupo da caulinita. Observa-se também, a falta de orientação dos argilominerais e a ocorrência de vazios entre as placas de caulinita. 


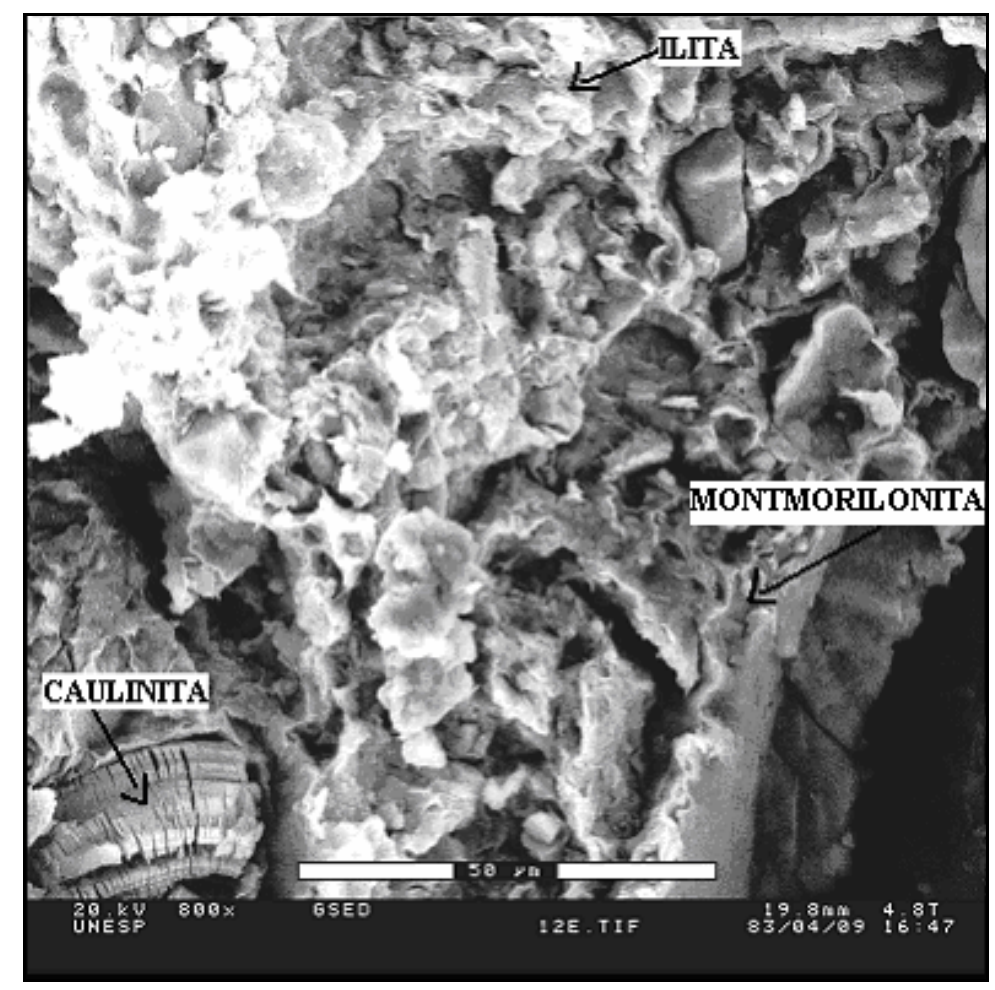

FIGURA 62. Composição mineralógica do material 1. Presença de caulinita, ilita e montmorilonita.

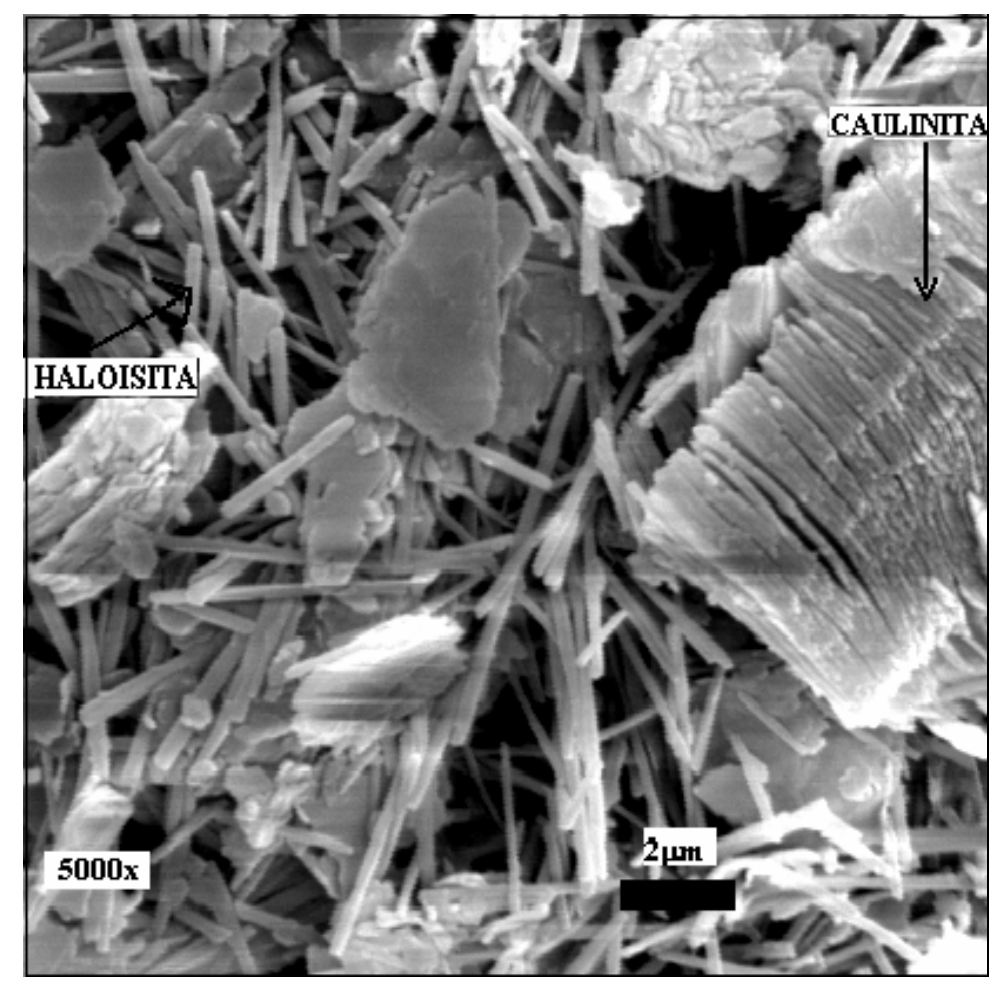

FIGURA 63. Imagem da amostra do material 1 , mostrando a presença de caulinita e haloisita. 
Nas Figuras 64 e 65, estão representadas imagens obtidas para o material 2. Tratase do material que apresentou o maior potencial expansivo. Pode-se observar na Figura 64, as trincas no material devido ao processo de secagem, o que deve favorecer o processo expansivo, quando o material é umedecido. Na Figura 65 observa-se a textura bem orientada do material e os vazios de pequenas dimensões entre as placas de argilominerais.

$\mathrm{Na}$ Figura 66, observam-se vazios de grandes dimensões no material 3 e na Figura 67, a presença de microvazios entre as placas dos argilominerais, o que provavelmente favorece a expansão do material, quando submetido a variações de umidade.

Nas Figuras 68 e 69, estão representadas imagens de microscopia realizadas para o material 4, onde na primeira são mostradas as trincas geradas devido ao processo de secagem e na segunda uma visão geral da textura medianamente orientada e do predomínio de argilominerais na composição mineralógica deste material.

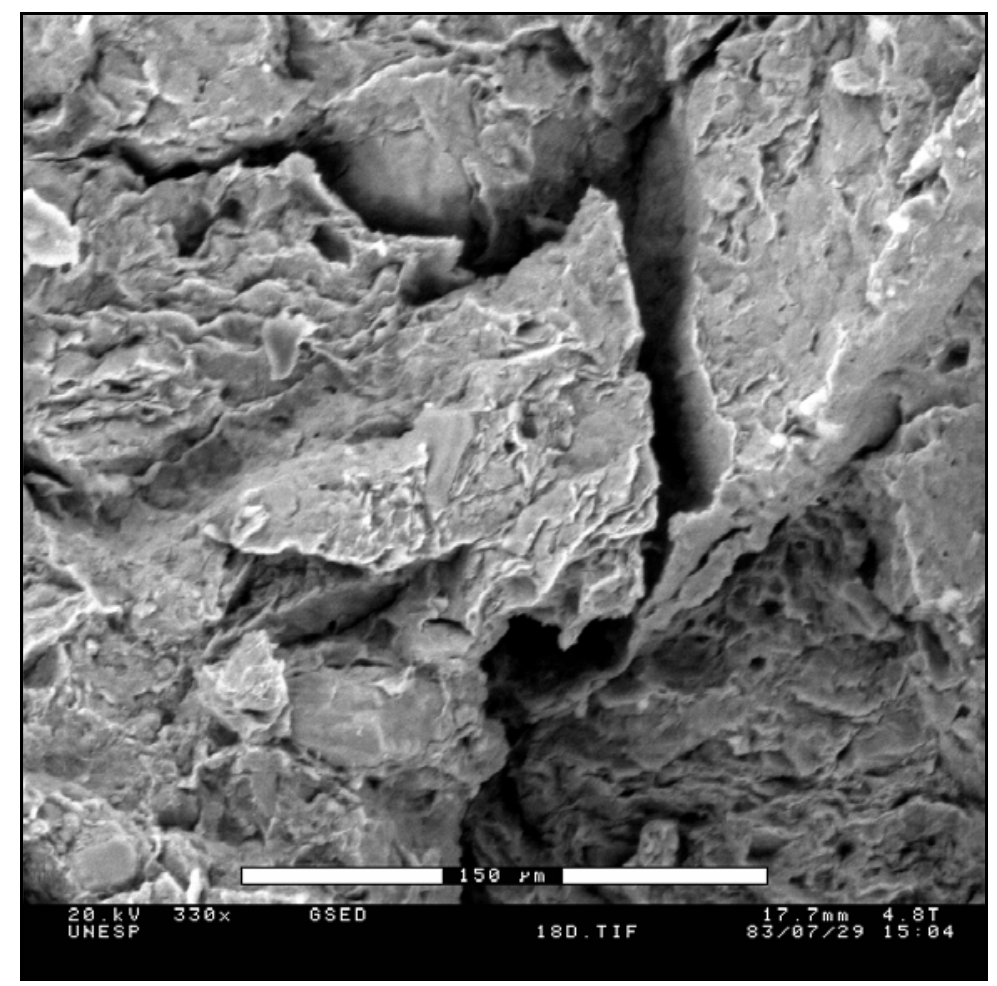

FIGURA 64. Fendas geradas no material 2, devido ao processo de secagem. 


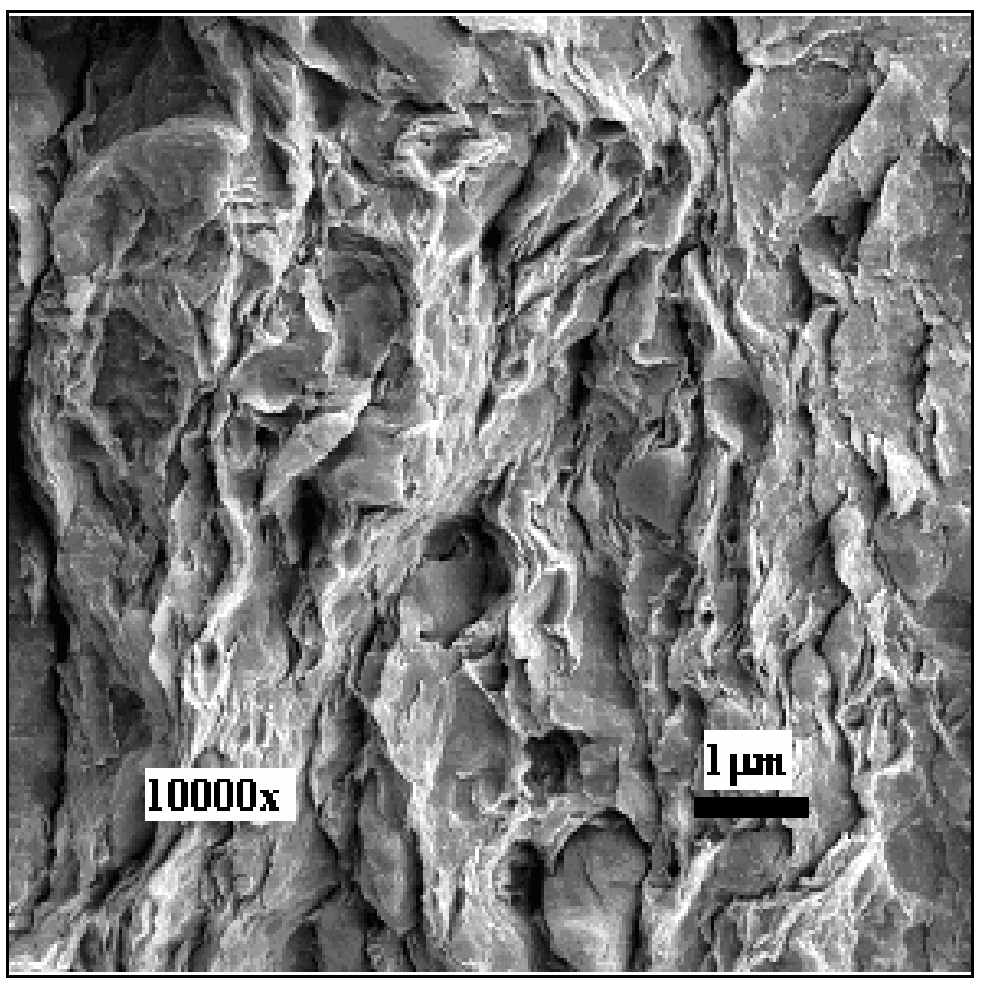

FIGURA 65. Aspecto da textura orientada do material 2.

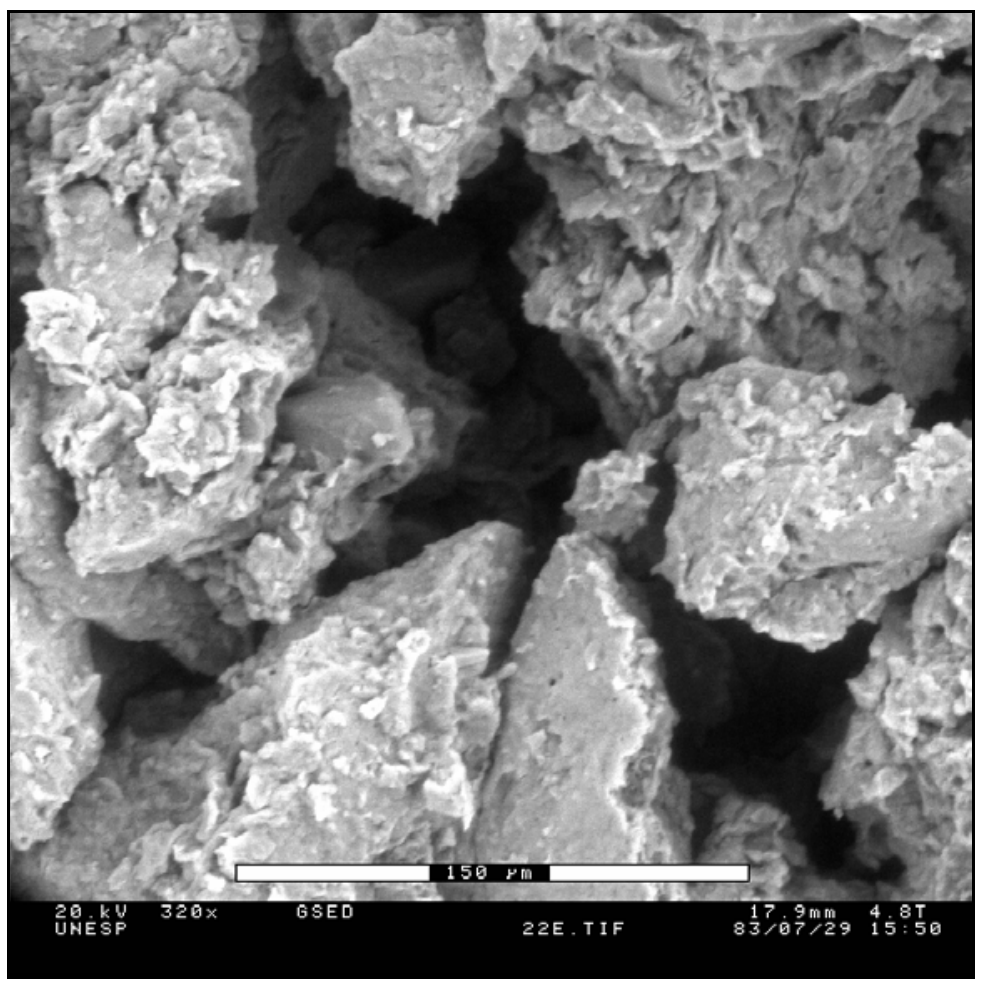

FIGURA 66. Vazios de grandes dimensões no material 3. 


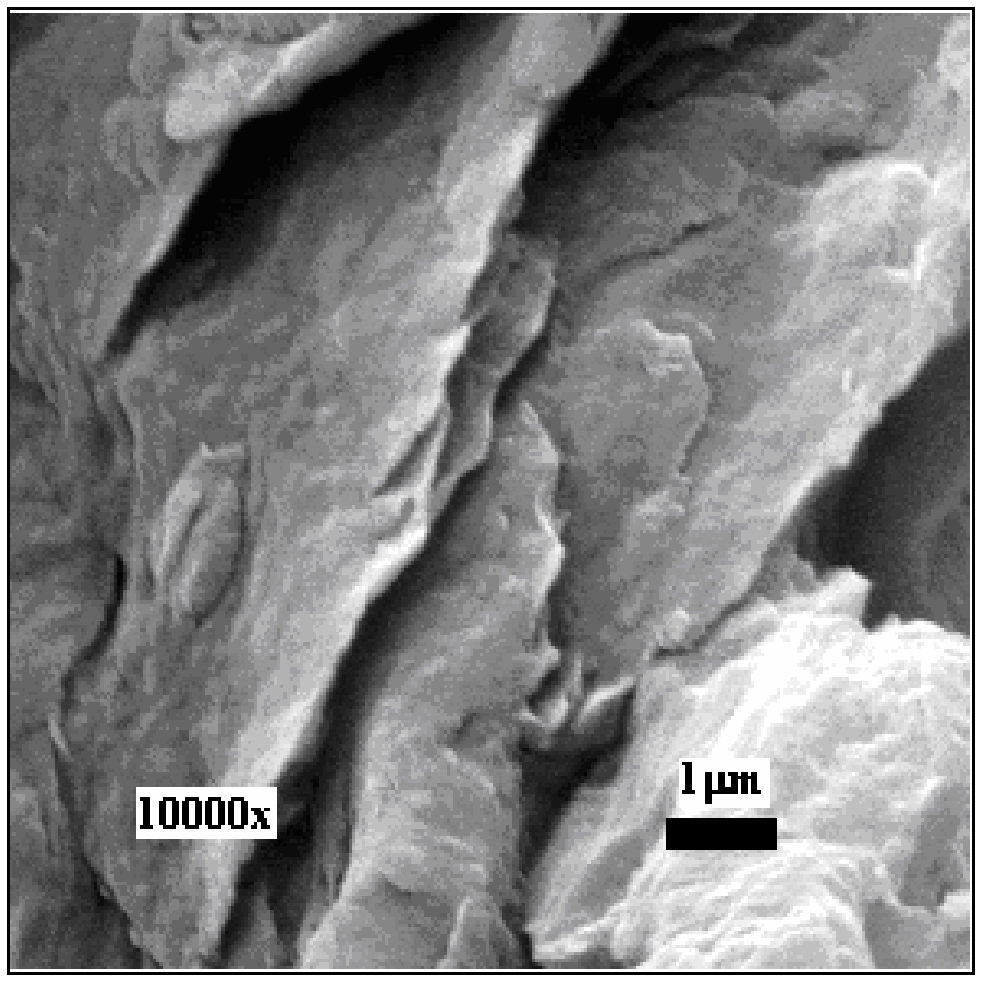

FIGURA 67. Detalhe dos microvazios entre as placas dos argilominerais no material 3.

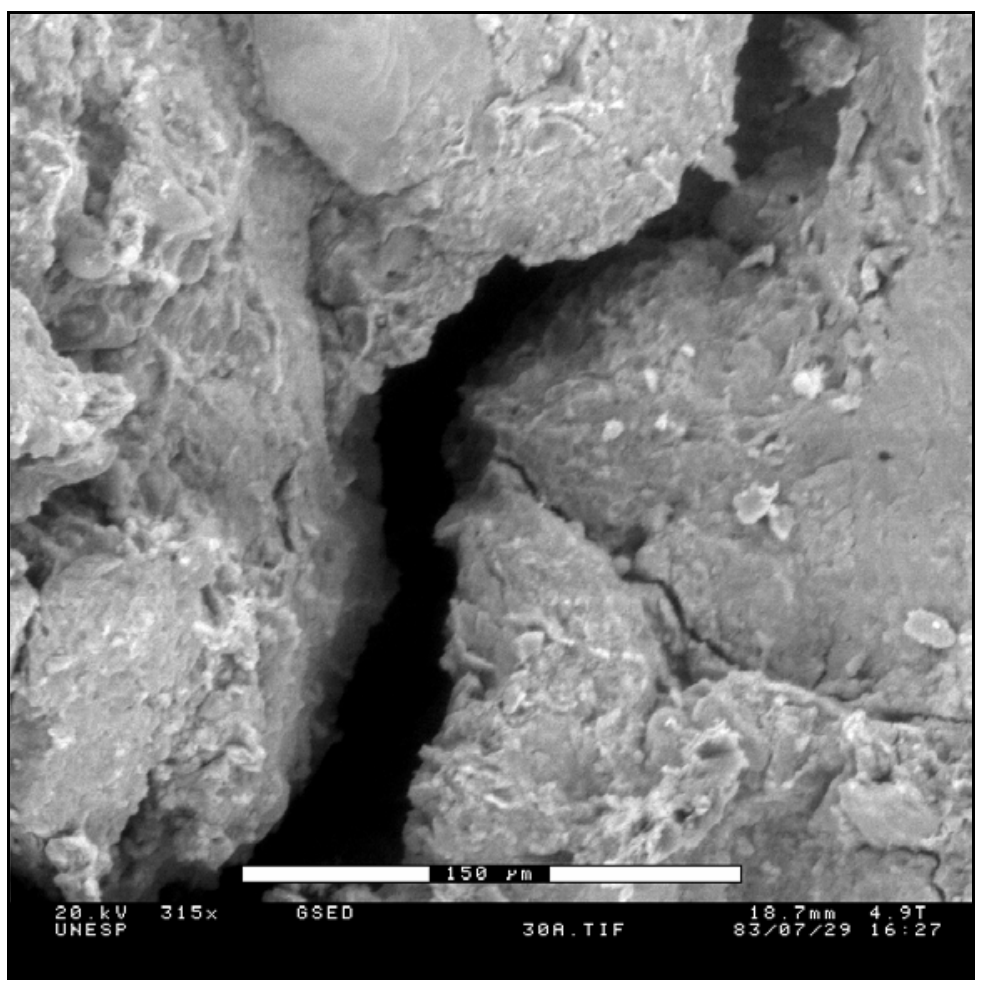

FIGURA 68. Presença de trincas de grandes dimensões no material 4. 


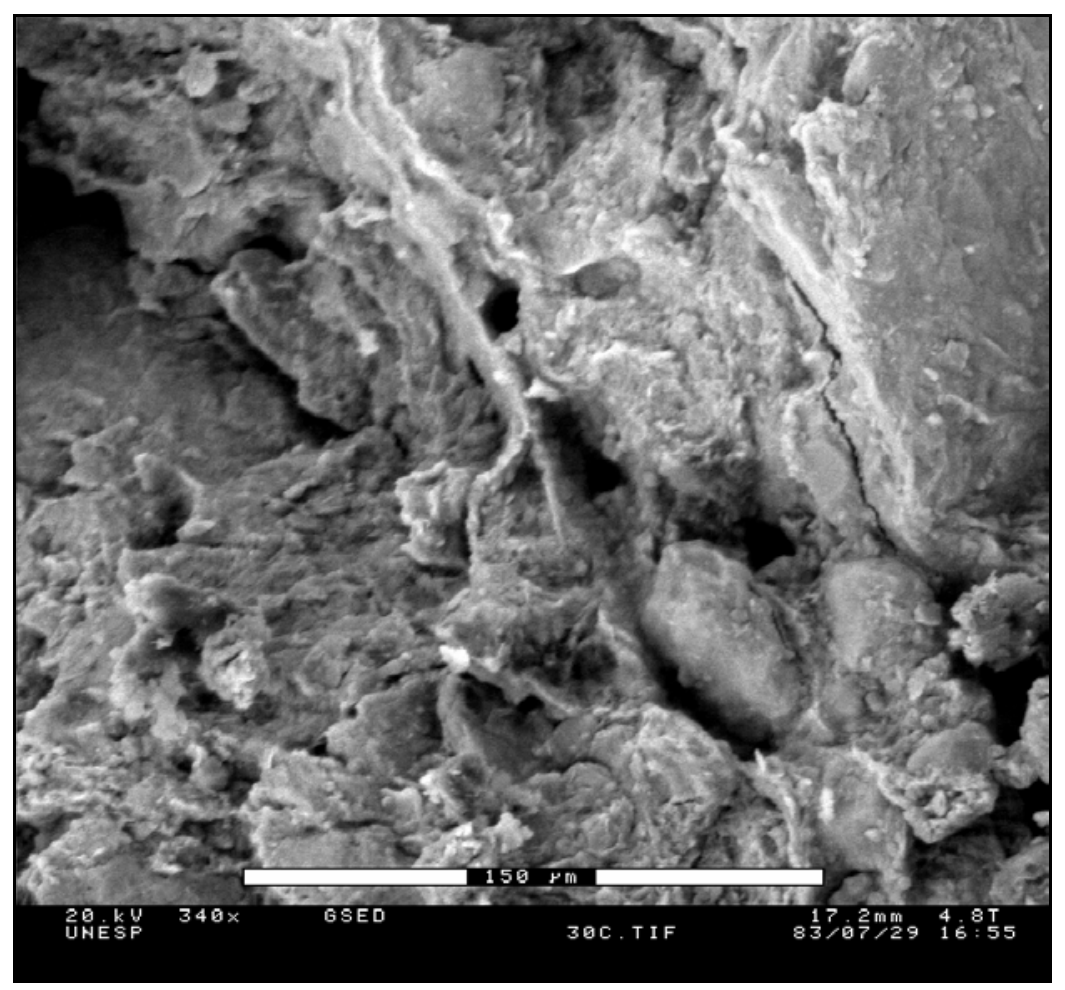

FIGURA 69. Aspecto geral da textura do material 4.

$\mathrm{Na}$ Figura 70a, pode-se observar minerais em processo de alteração e na 70b, a análise qualitativa da composição química do material no ponto $\mathrm{A}$, determinada pela leitura de EDS, caracterizando a presença de feldspato sódico em meio ao argilominerais que compõem o material 5.

As Figuras 71 e 72 mostram a presença de argilominerais do grupo das esmectitas e um grande número de vazios diminutos entre as camadas dos argilominerais no material 5. 


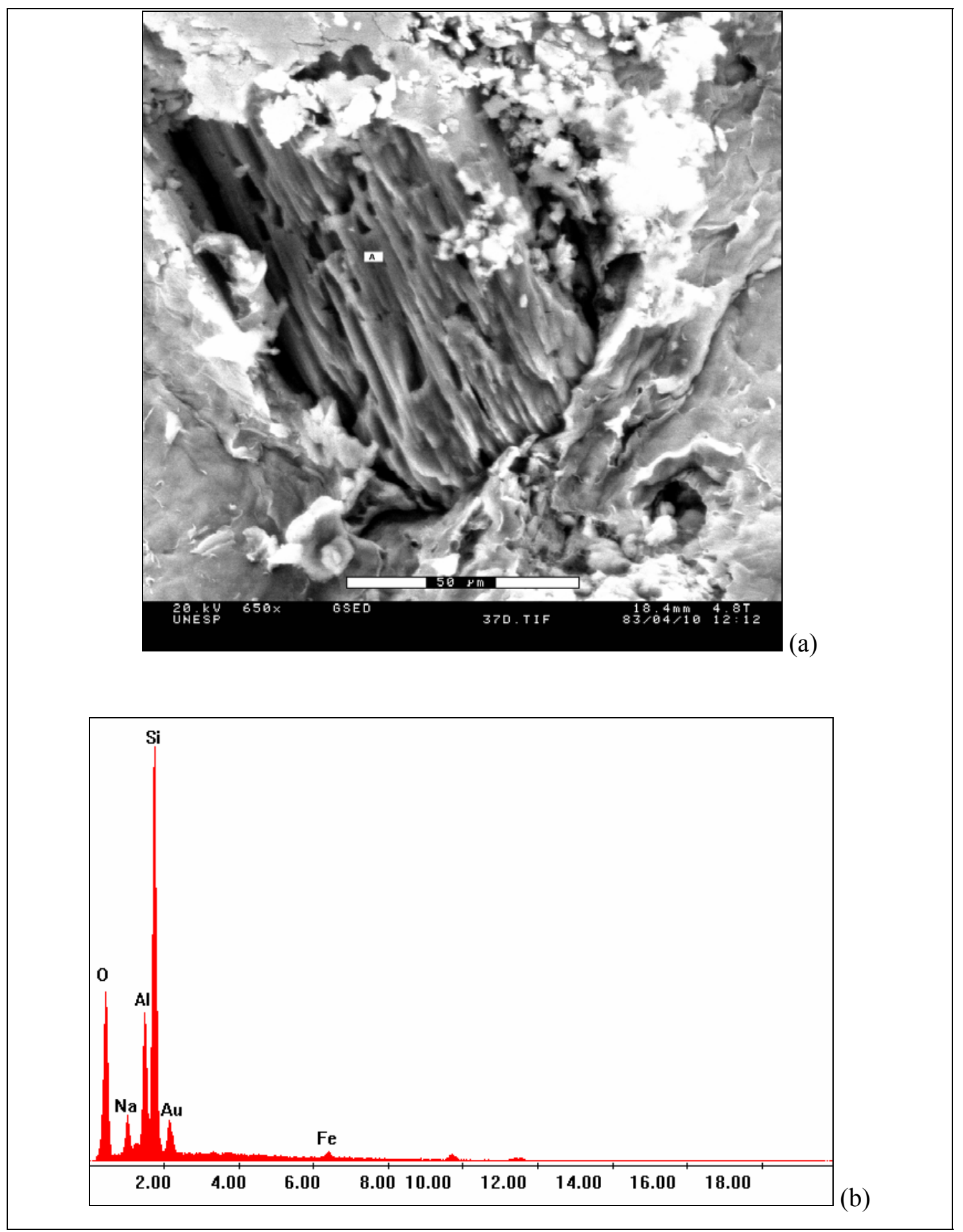

FIGURA 70. a) Presença de feldspato na composição mineralógica do material 5 e b) Composição química do mineral central (feldspato sódico alterado). 


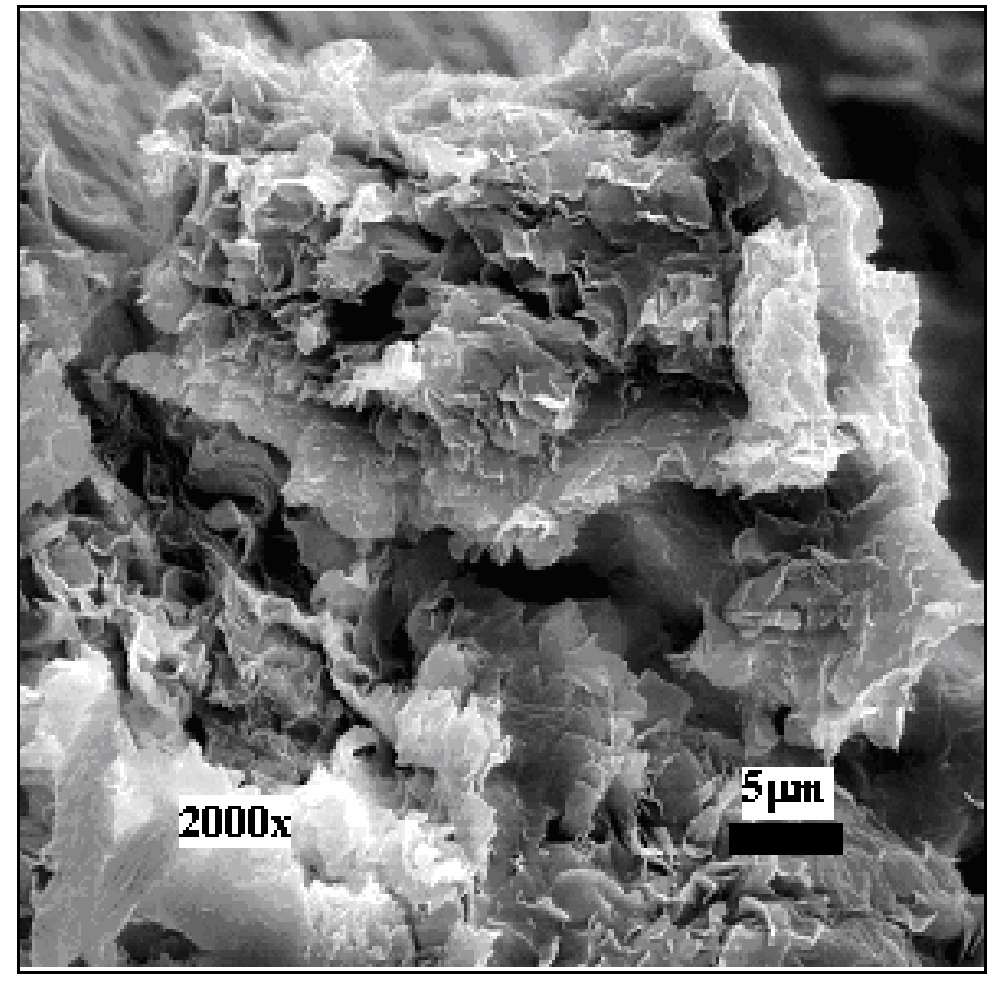

FIGURA 71. Aspecto de argilominerais do grupo das esmectitas (montmorilonita) presentes no material 5.

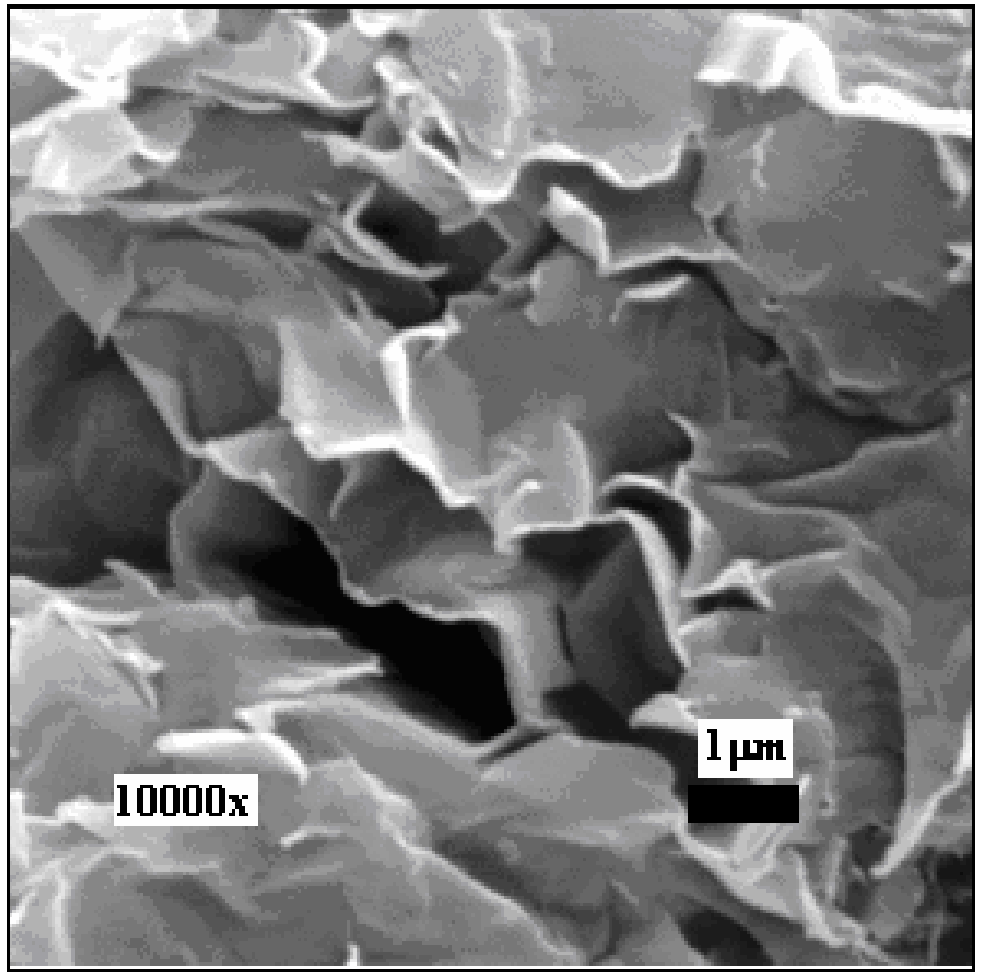

FIGURA 72. Detalhe da foto anterior. 


\subsubsection{Condutividade Elétrica}

Os valores de condutividade obtidos à temperatura constante de $20^{\circ} \mathrm{C}$ para os materiais $1,2,3,4$ e 5 foram de $74,3 \mu \mathrm{S} ; 58,7 \mu \mathrm{S} ; 40,1 \mu \mathrm{S} ; 54,00 \mu \mathrm{S}$ e $19,3 \mu \mathrm{S}$, respectivamente. Os resultados mostram que existem concentrações heterogêneas de sais dissolvidos na água do solo, o que deve influir na sucção osmótica quando trata-se da retenção de água de cada material.

\subsection{Retenção de Água no Solo}

\subsubsection{Resultados dos ensaios de Papel Filtro e Câmara de Pressão}

Os resultados dos ensaios da câmara de pressão (sucção matricial) e Papel Filtro (sucções total e matricial), permitiram a determinação das curvas representativas dos dados em gráficos de Sucção Matricial ou Total (kPa) e Umidade Gravimétrica (\%) para os cinco materiais estudados. Para que os dados experimentais obtidos em cada ensaio pudessem ser visualizados em conjunto, optou-se por colocá-los num mesmo gráfico, onde já estão representadas as curvas de ajuste geradas mediante regressões não lineares, a partir dos modelos matemáticos citados anteriormente (equações 8 a 13).

Nas Tabelas 14 e 15, são mostrados os resultados experimentais dos ensaios de papel filtro para a determinação da sucção matricial e nas Figuras 73, 74, 75, 76 e 77, os gráficos representativos destes dados. 
TABELA 14. Dados Experimentais de Umidade gravimétrica (\%) e Sucção matricial (kPa) obtidos para os materiais 1, 2 e 3, a partir do método do Papel Filtro

\begin{tabular}{|c|c|c|c|c|c|}
\hline \multicolumn{2}{|c|}{ Material 1 } & \multicolumn{2}{|c|}{ Material 2} & \multicolumn{2}{|c|}{ Material 3} \\
\hline \multicolumn{6}{|c|}{ Dados Experimentais } \\
\hline $\begin{array}{c}\text { Umidade Gravimétrica } \\
(\%)\end{array}$ & $\begin{array}{c}\text { Sucção Matricial } \\
(\mathrm{kPa})\end{array}$ & $\begin{array}{c}\text { Umidade Gravimétrica } \\
(\%)\end{array}$ & $\begin{array}{c}\text { Sucção Matricial } \\
(\mathrm{kPa})\end{array}$ & $\begin{array}{c}\text { Umidade Gravimétrica } \\
(\%)\end{array}$ & $\begin{array}{c}\text { Sucção Matricial } \\
(\mathrm{kPa})\end{array}$ \\
\hline 10,6 & 8069,9 & 10,9 & 37015,6 & 10,9 & 33061,7 \\
\hline 17,6 & 1814,0 & 11,0 & 36011,5 & 11,0 & 28786,2 \\
\hline 24,0 & 512,6 & 11,1 & 35667,5 & 11,3 & 28363,4 \\
\hline 24,3 & 490,5 & 19,2 & 10087,9 & 16,6 & 12999,5 \\
\hline 26,4 & 360,9 & 21,2 & 6538,0 & 23,4 & 4122,2 \\
\hline 26,7 & 336,0 & 22,0 & 5488,6 & 24,4 & 3141,1 \\
\hline 27,2 & 311,0 & 24,8 & 4323,9 & 25,0 & 2933,5 \\
\hline 29,6 & 187,9 & 26,4 & 2931,5 & 26,8 & 2167,0 \\
\hline 30,3 & 156,7 & 27,2 & 2583,6 & 27,0 & 2075,6 \\
\hline 33,0 & 92,7 & 28,0 & 1813,0 & 29,9 & 1247,4 \\
\hline 34,1 & 62,0 & 28,3 & 1736,2 & 31,8 & 785,8 \\
\hline 34,9 & 60,6 & 29,0 & 1509,7 & 32,8 & 529,8 \\
\hline 36,3 & 39,5 & 31,6 & 856,4 & 39,3 & 78,4 \\
\hline 37,4 & 25,9 & 38,0 & 180,5 & 42,1 & 23,8 \\
\hline 38,0 & 16,7 & 44,3 & 20,4 & 43,5 & 11,4 \\
\hline 38,5 & 15,3 & 44,5 & 20,2 & 43,6 & 10,6 \\
\hline 39,7 & 7,6 & 46,1 & 6,2 & 44,1 & 7,5 \\
\hline 39,7 & 7,5 & 46,4 & 5,8 & 44,9 & 6,3 \\
\hline 40,3 & 6,1 & & & & \\
\hline
\end{tabular}


TABELA 15. Dados Experimentais de Umidade gravimétrica (\%) e Sucção matricial $(\mathrm{kPa})$ obtidos para os materiais 4 e 5, através do método do Papel Filtro

\begin{tabular}{|c|c|c|c|}
\hline \multicolumn{2}{|c|}{ Material 4} & \multicolumn{2}{|c|}{ Material 5} \\
\hline \multicolumn{4}{|c|}{ Dados Experimentais } \\
\hline $\begin{array}{c}\text { Umidade Gravimétrica } \\
(\%)\end{array}$ & $\begin{array}{c}\text { Sucção Matricial } \\
(\mathrm{kPa})\end{array}$ & $\begin{array}{c}\text { Umidade Gravimétrica } \\
(\%)\end{array}$ & $\begin{array}{c}\text { Sucção Matricial } \\
(\mathrm{kPa})\end{array}$ \\
\hline 8,7 & 34743,8 & 6,1 & 32556,0 \\
\hline 8,9 & 34656,8 & 6,5 & 28161,7 \\
\hline 9,0 & 32207,0 & 6,5 & 27953,6 \\
\hline 16,0 & 12771,1 & 6,9 & 24435,2 \\
\hline 16,9 & 10907,1 & 8,5 & 14309,6 \\
\hline 17,7 & 8706,0 & 9,2 & 11519,3 \\
\hline 18,5 & 8078,9 & 10,0 & 8166,5 \\
\hline 21,8 & 4579,0 & 11,6 & 4792,9 \\
\hline 28,1 & 2148,0 & 12,4 & 3549,3 \\
\hline 34,6 & 857,9 & 12,9 & 3367,1 \\
\hline 35,5 & 721,4 & 14,0 & 2229,0 \\
\hline 38,4 & 523,7 & 14,9 & 1573,4 \\
\hline 39,1 & 422,5 & 14,9 & 1459,4 \\
\hline 40,0 & 304,5 & 15,7 & 1025,8 \\
\hline 41,5 & 232,4 & 19,3 & 256,0 \\
\hline 48,0 & 62,3 & 22,6 & 69,3 \\
\hline 48,1 & 58,5 & 25,4 & 14,9 \\
\hline 49,3 & 37,7 & 26,6 & 6,9 \\
\hline 50,9 & 18,8 & 26,7 & 6,4 \\
\hline 51,1 & 14,4 & 26,9 & 5,7 \\
\hline
\end{tabular}

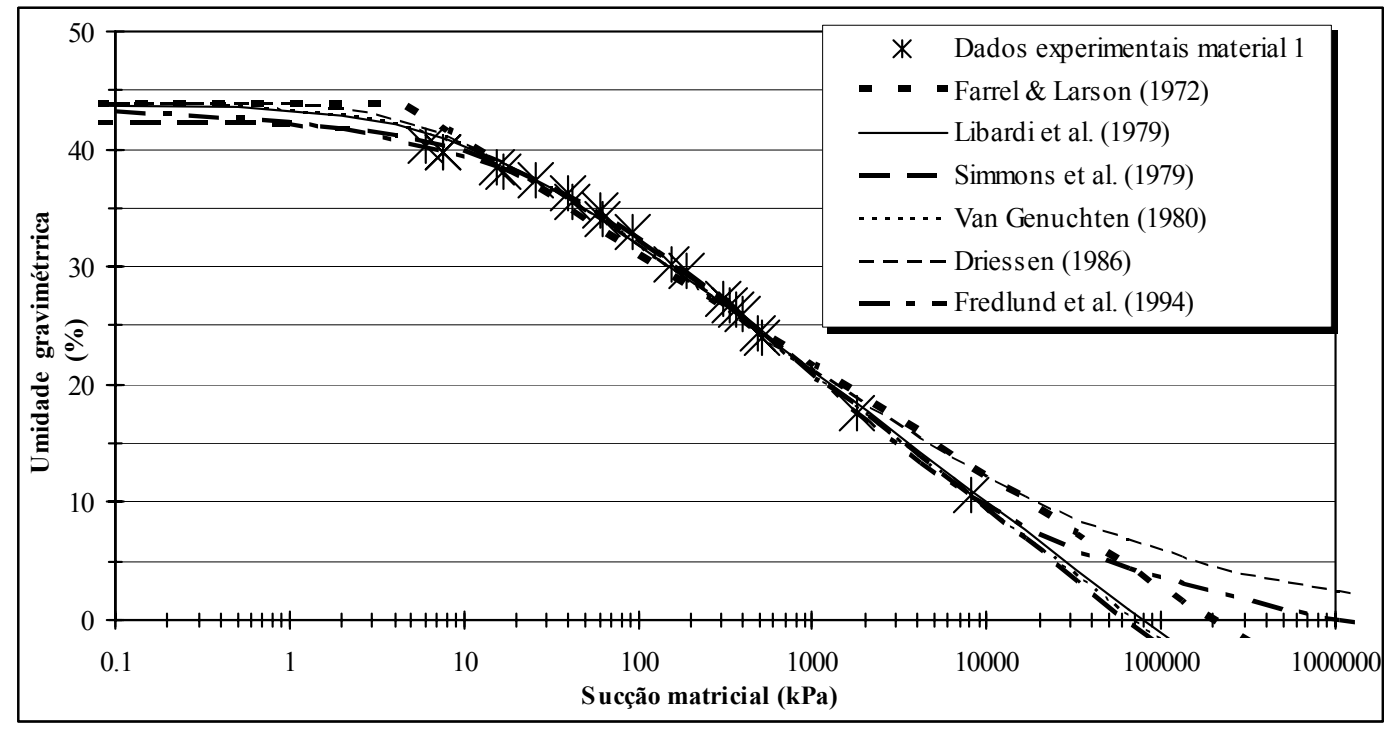

FIGURA 73. Curva de retenção para o material 1 (Papel Filtro). 


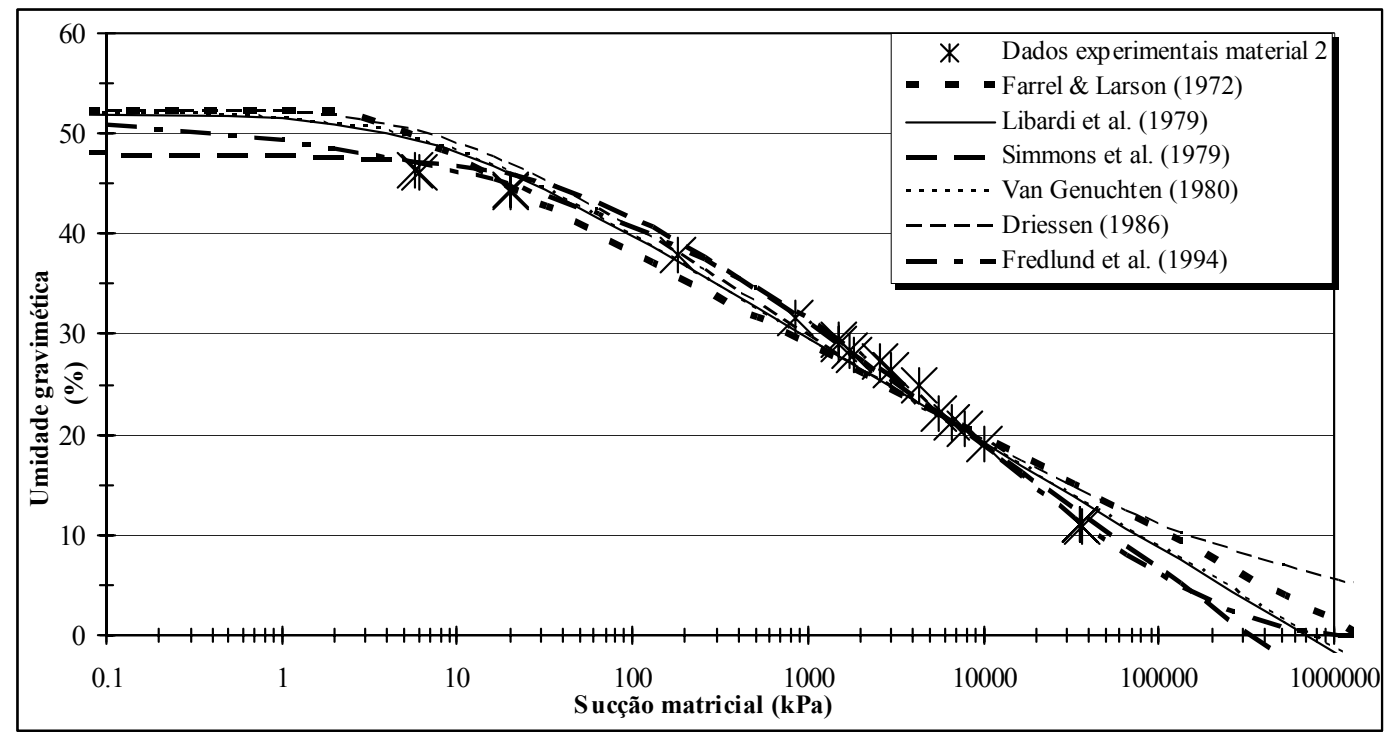

FIGURA 74. Curva de retenção para o material 2 (Papel Filtro).

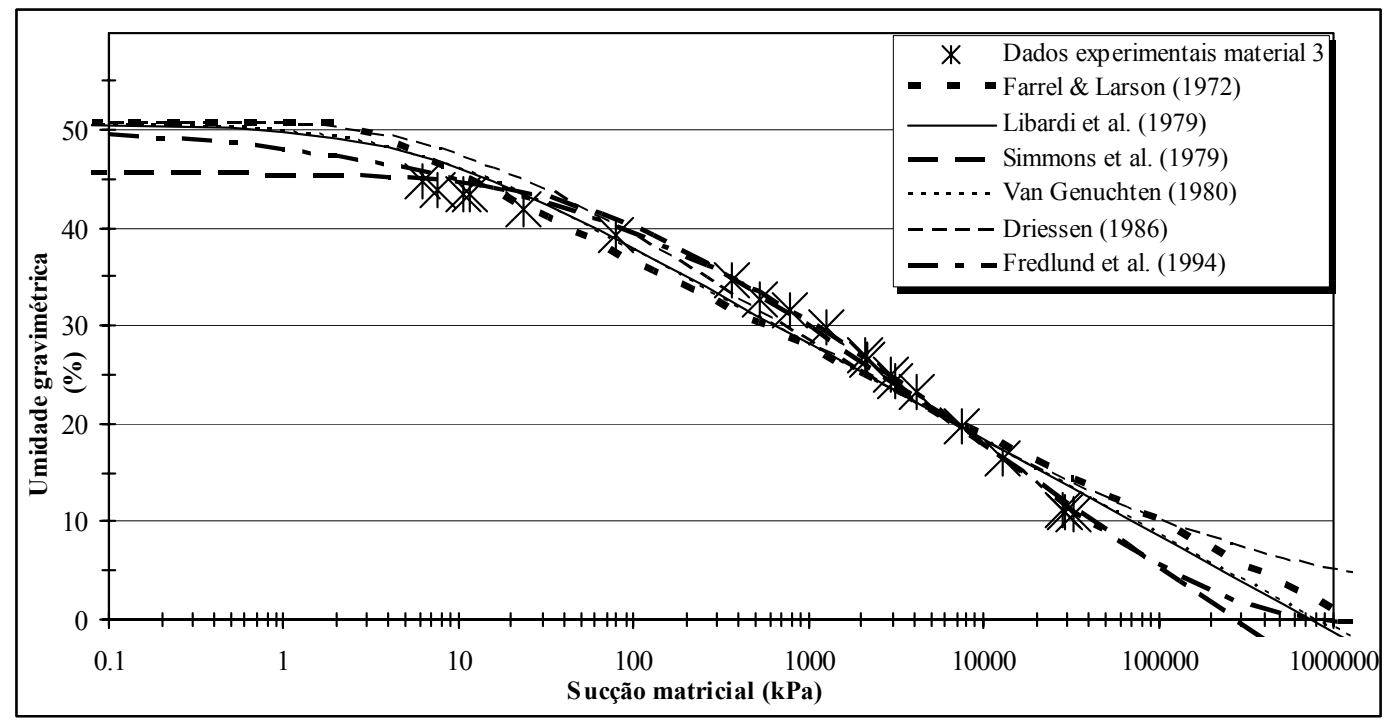

FIGURA 75. Curva de retenção para o material 3 (Papel Filtro). 


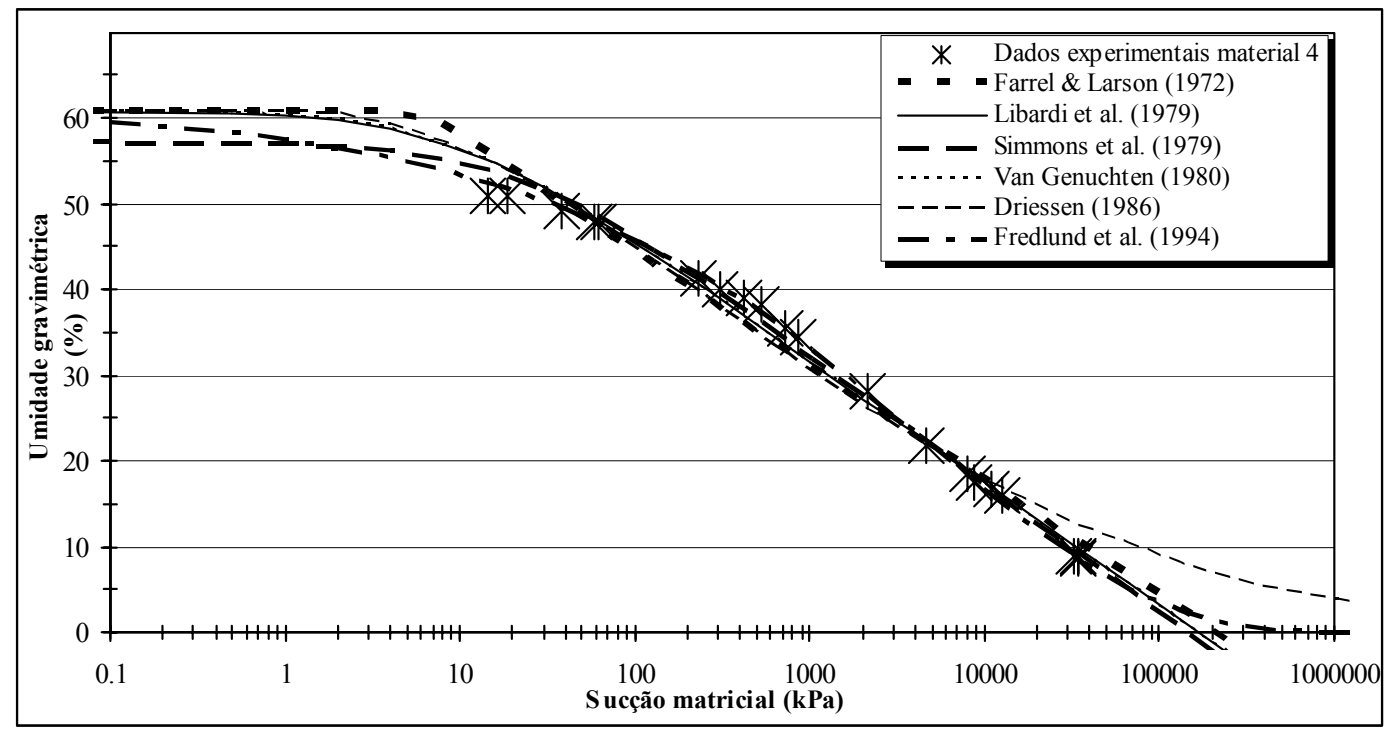

FIGURA 76. Curva de retenção para o material 4 (Papel Filtro).

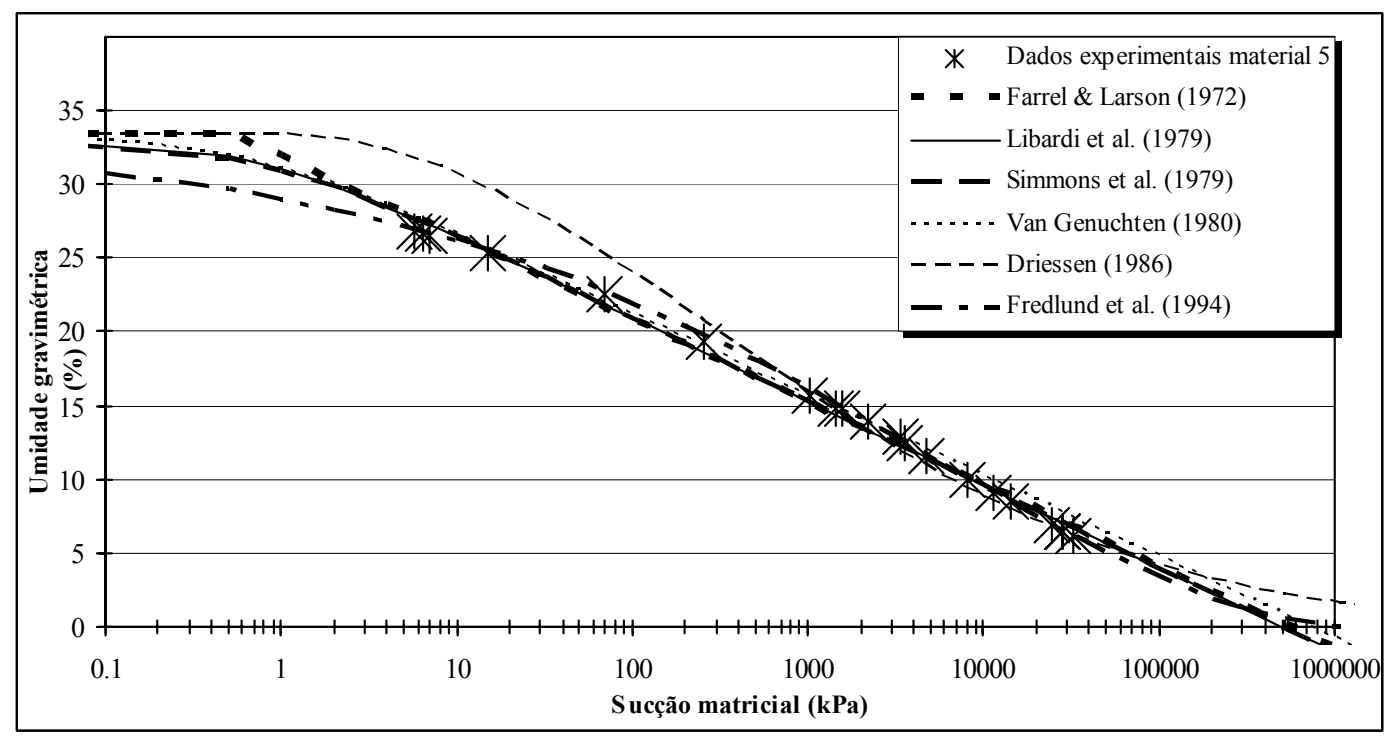

FIGURA 77. Curva de retenção para o material 5 (Papel Filtro).

Os parâmetros de ajuste das Curvas de Retenção (relativos a cada modelo) para os valores experimentais gerados no ensaio de papel filtro (sucção matricial) podem ser observados nas Tabelas 16, 17, 18, 19, 20 e 21. 
TABELA 16. Parâmetros de ajuste da Curva de Retenção através da equação matemática de Farrel \& Larson (1972)

\begin{tabular}{cccccc}
\hline $\begin{array}{c}\text { PARÂMETROS } \\
\text { Material }\end{array}$ & $\begin{array}{c}\mathrm{w}_{\mathrm{S}} \\
(\%)\end{array}$ & $\begin{array}{c}\psi_{\text {crit }} \\
(\mathrm{kPa})\end{array}$ & $\begin{array}{c}\mathrm{w}_{\mathrm{r}} \\
(\%)\end{array}$ & $\alpha$ & $\mathrm{r}^{2}$ \\
\hline 1 & 43,8 & 4,5719 & 10,6 & 8,0885 & 0,975 \\
2 & 52,1 & 3,0254 & 10,9 & 10,2883 & 0,969 \\
3 & 50,7 & 2,6235 & 10,9 & 10,3252 & 0,963 \\
4 & 61,0 & 5,9605 & 8,7 & 8,9911 & 0,983 \\
5 & 33,4 & 0,5436 & 6,1 & 11,2913 & 0,995 \\
\hline
\end{tabular}

TABELA 17. Parâmetros de ajuste da Curva de Retenção através da equação matemática de Simmons, Nielsen \& Biggar (1979)

\begin{tabular}{ccccc}
\hline $\begin{array}{c}\text { PARÂMETROS } \\
\text { Material }\end{array}$ & $\begin{array}{c}\mathrm{w}_{\mathrm{S}} \\
\mathbf{( \% )}\end{array}$ & $\alpha$ & $\beta$ & $\mathrm{r}^{2}$ \\
\hline 1 & 42,4 & 15,4889 & $-19,6261$ & 0,996 \\
2 & 48,0 & 43,6961 & $-18,6672$ & 0,989 \\
3 & 45,7 & 57,3637 & $-18,5455$ & 0,986 \\
4 & 57,3 & 21,8168 & $-15,3411$ & 0,992 \\
5 & 33,2 & 0,6769 & $-40,7446$ & 0,995 \\
\hline
\end{tabular}

TABELA 18. Parâmetros de ajuste da Curva de Retenção através da equação matemática de Libardi et al. (1979)

\begin{tabular}{ccccc}
\hline $\begin{array}{c}\text { PARÂMETROS } \\
\text { Material }\end{array}$ & $\begin{array}{c}\mathrm{w}_{\mathrm{S}} \\
(\boldsymbol{\%})\end{array}$ & $\alpha$ & $\beta$ & $\mathrm{r}^{2}$ \\
\hline 1 & 43,8 & 9,5055 & $-20,6021$ & 0,994 \\
2 & 52,1 & 7,1876 & $-22,0284$ & 0,980 \\
3 & 50,7 & 5,3234 & $-23,4054$ & 0,972 \\
4 & 61,0 & 9,1154 & $-16,0921$ & 0,990 \\
5 & 33,4 & 0,6154 & $-40,795$ & 0,995 \\
\hline
\end{tabular}

TABELA 19. Parâmetros de ajuste da Curva de Retenção através da equação matemática de Van Genuchten (1980)

\begin{tabular}{ccccccc}
\hline $\begin{array}{c}\text { PARÂMETROS } \\
\text { Material }\end{array}$ & $\begin{array}{c}\mathrm{W}_{\mathrm{S}} \\
\left(\mathrm{cm}^{3} / \mathrm{cm}^{3}\right)\end{array}$ & $\begin{array}{c}\mathrm{W}_{\mathrm{r}} \\
\left(\mathrm{cm}^{3} / \mathrm{cm}^{3}\right)\end{array}$ & $\begin{array}{c}\alpha \\
(1 / \mathrm{kPa})\end{array}$ & $\mathrm{n}$ & $\mathrm{m}$ & $\mathrm{r}^{2}$ \\
\hline 1 & 0,438 & $-21,152$ & 0,1038 & 1,0023 & 0,0023 & 0,994 \\
2 & 0,521 & $-6,474$ & 0,1292 & 1,0067 & 0,0067 & 0,978 \\
3 & 0,507 & $-6,37$ & 0,1766 & 1,0064 & 0,0064 & 0,970 \\
4 & 0,610 & $-17,445$ & 0,1057 & 1,0035 & 0,0035 & 0,989 \\
5 & 0,334 & $-21,512$ & 1,595 & 1,0011 & 0,0011 & 0,995 \\
\hline
\end{tabular}

Cabe ressaltar, que os resultados de umidade gravimétrica residual negativos da Tabela 19, não tem significado físico, foram obtidos por ajuste da curva de retenção. 
TABELA 20. Parâmetros de ajuste da Curva de Retenção através da equação matemática de Driessen (1986)

\begin{tabular}{cccc}
\hline $\begin{array}{c}\text { PARÂMETROS } \\
\text { Material }\end{array}$ & $\begin{array}{c}\mathrm{w}_{\mathrm{S}} \\
(\%)\end{array}$ & $\gamma$ & $\mathrm{r}^{2}$ \\
\hline 1 & 43,8 & 0,0152 & 0,988 \\
2 & 52,1 & 0,0117 & 0,968 \\
3 & 50,7 & 0,012 & 0,958 \\
4 & 61,0 & 0,0144 & 0,976 \\
5 & 33,4 & 0,0156 & 0,921 \\
\hline
\end{tabular}

TABELA 21. Parâmetros de ajuste da Curva de Retenção através da equação matemática de Fredlund et al. (1994)

\begin{tabular}{ccccccc}
\hline $\begin{array}{c}\text { PARÂMETROS } \\
\text { Material }\end{array}$ & $\begin{array}{c}\mathrm{w}_{\mathrm{S}} \\
\left(\mathrm{cm}^{3} / \mathrm{cm}^{3}\right)\end{array}$ & $\begin{array}{c}\psi_{\mathrm{r}} \\
(\mathrm{kPa})\end{array}$ & $\mathrm{a}$ & $\mathrm{n}$ & $\mathrm{m}$ & $\mathrm{r}^{2}$ \\
\hline 1 & 0,438 & $10^{6}$ & $7,16 \mathrm{E}+02$ & 0,492 & 2,433 & 0,999 \\
2 & 0,521 & $10^{6}$ & $1,71 \mathrm{E}+16$ & 0,301 & 13347,528 & 0,998 \\
3 & 0,507 & $10^{6}$ & $7,60 \mathrm{E}+16$ & 0,30 & 20591,015 & 0,998 \\
4 & 0,610 & $10^{6}$ & $6,69 \mathrm{E}+14$ & 0,323 & 10996,987 & 0,999 \\
5 & 0,334 & $10^{6}$ & $2,15 \mathrm{E}+17$ & 0,237 & 4895,804 & 0,999 \\
\hline
\end{tabular}

Nas Tabelas 22 e 23, são mostrados os resultados experimentais dos ensaios de papel filtro para a determinação da sucção total e nas Figuras 78, 79, 80, 81 e 82, os gráficos representativos destes dados. 
TABELA 22. Dados Experimentais de Umidade gravimétrica (\%) e Sucção total (kPa) obtidos para os materiais 1, 2 e 3, através do Método do Papel Filtro

\begin{tabular}{|c|c|c|c|c|c|}
\hline \multicolumn{2}{|c|}{ Material 1} & \multicolumn{2}{|c|}{ Material 2} & \multicolumn{2}{|c|}{ Material 3} \\
\hline \multicolumn{6}{|c|}{ Dados Experimentais } \\
\hline $\begin{array}{c}\text { Umidade Gravimétrica } \\
(\%)\end{array}$ & $\begin{array}{c}\text { Sucção Total } \\
(\mathrm{kPa})\end{array}$ & $\begin{array}{c}\text { Umidade Gravimétrica } \\
(\%)\end{array}$ & $\begin{array}{l}\text { Sucção Total } \\
(\mathrm{kPa})\end{array}$ & $\begin{array}{c}\text { Umidade Gravimétrica } \\
(\%)\end{array}$ & $\begin{array}{c}\text { Sucção Total } \\
(\mathrm{kPa})\end{array}$ \\
\hline 7,8 & 31774,0 & 13,9 & 35735,5 & 14,2 & 34108,2 \\
\hline 8,5 & 26086,5 & 17,9 & 21219,8 & 16,7 & 23026,7 \\
\hline 10,1 & 19901,2 & 18,0 & 21014,4 & 17,1 & 22590,9 \\
\hline 11,0 & 15444,7 & 18,6 & 18951,5 & 17,5 & 22388,3 \\
\hline 18,2 & 3749,6 & 25,0 & 6024,5 & 24,9 & 6108,8 \\
\hline 20,8 & 2139,4 & 25,7 & 5964,1 & 25,9 & 5448,4 \\
\hline 25,4 & 1034,0 & 27,3 & 4283,2 & 31,6 & 1969,6 \\
\hline 31,9 & 305,9 & 32,6 & 1423,5 & 34,6 & 1046,6 \\
\hline 34,3 & 186,6 & 33,0 & 1354,4 & 36,4 & 615,7 \\
\hline 36,2 & 102,6 & 38,3 & 376,1 & 38,3 & 359,0 \\
\hline 36,5 & 97,6 & 39,0 & 349,9 & 39,3 & 272,2 \\
\hline 37,3 & 66,5 & 42,7 & 92,6 & 39,7 & 264,2 \\
\hline 38,6 & 44,6 & 43,2 & 80,5 & 40,7 & 153,0 \\
\hline 38,8 & 40,7 & 43,5 & 80,3 & 42,6 & 76,3 \\
\hline 39,0 & 30,3 & 44,3 & 37,9 & 44,8 & 31,6 \\
\hline 39,1 & 29,5 & 44,9 & 32,5 & 46,8 & 9,6 \\
\hline
\end{tabular}


TABELA 23. Dados Experimentais de Umidade gravimétrica (\%) e Sucção total (kPa) obtidos para os materiais 4 e 5, a partir do método do Papel Filtro

\begin{tabular}{|c|c|c|c|}
\hline \multicolumn{2}{|c|}{ Material 4} & \multicolumn{2}{|c|}{ Material 5} \\
\hline \multicolumn{4}{|c|}{ Dados Experimentais } \\
\hline $\begin{array}{c}\text { Umidade Gravimétrica } \\
(\%)\end{array}$ & $\begin{array}{l}\text { Sucção Total } \\
(\mathrm{kPa})\end{array}$ & $\begin{array}{c}\text { Umidade Gravimétrica } \\
(\%)\end{array}$ & $\begin{array}{c}\text { Sucção Total } \\
(\mathrm{kPa})\end{array}$ \\
\hline 12,4 & 28435,4 & 8,4 & 22319,7 \\
\hline 13,0 & 27343,4 & 8,4 & 21890,0 \\
\hline 14,8 & 24224,4 & 9,1 & 17233,5 \\
\hline 15,7 & 23342,8 & 10,3 & 12089,3 \\
\hline 22,6 & 8657,1 & 13,2 & 4968,6 \\
\hline 29,3 & 2852,0 & 15,1 & 2393,2 \\
\hline 34,2 & 1497,9 & 17,6 & 1006,2 \\
\hline 35,5 & 1254,0 & 19,6 & 522,0 \\
\hline 37,0 & 958,9 & 19,6 & 514,9 \\
\hline 39,6 & 665,2 & 21,5 & 262,5 \\
\hline 42,6 & 372,7 & 23,8 & 82,0 \\
\hline 44,4 & 244,4 & 24,2 & 61,1 \\
\hline 45,7 & 187,3 & 25,4 & 30,0 \\
\hline 46,8 & 144,9 & 26,1 & 18,7 \\
\hline 50,0 & 63,5 & 28,5 & 3,7 \\
\hline 52,6 & 25,0 & & \\
\hline
\end{tabular}

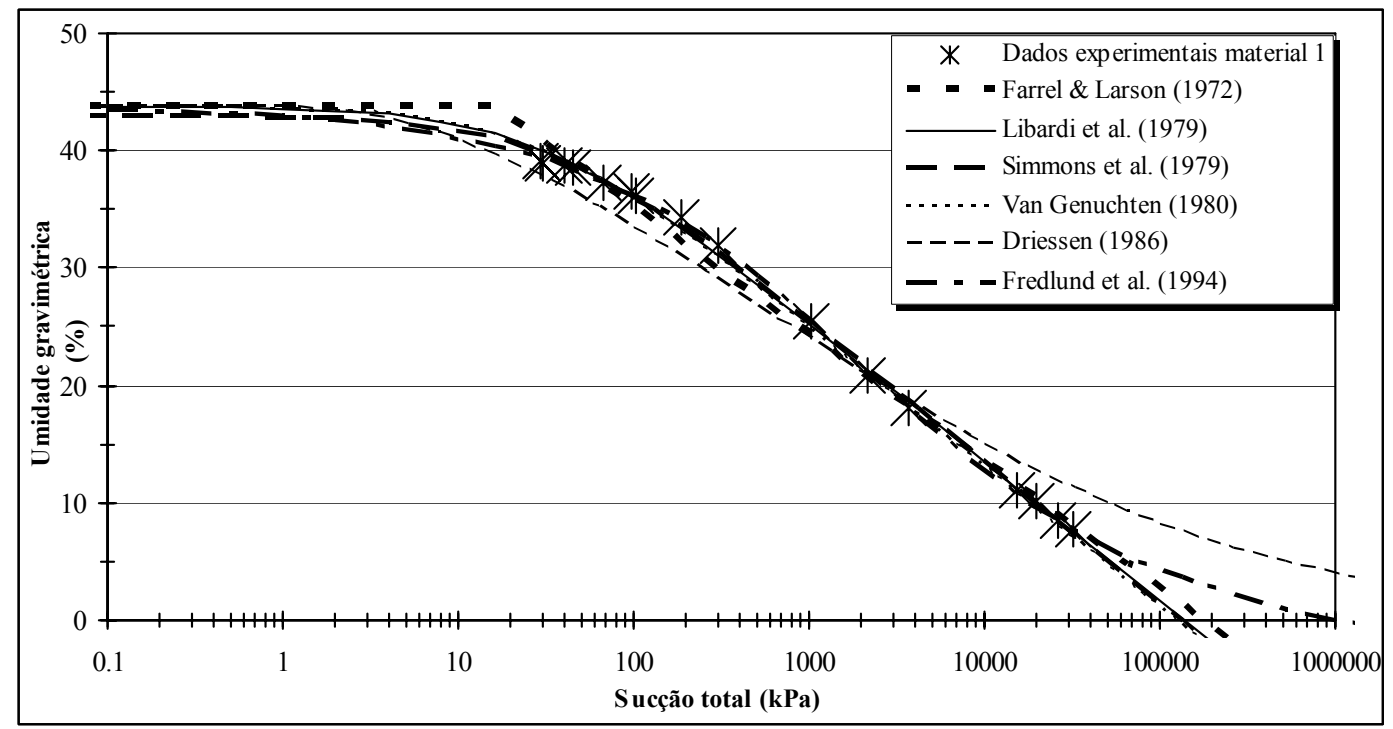

FIGURA 78. Curva de retenção para o material 1 (Papel Filtro). 


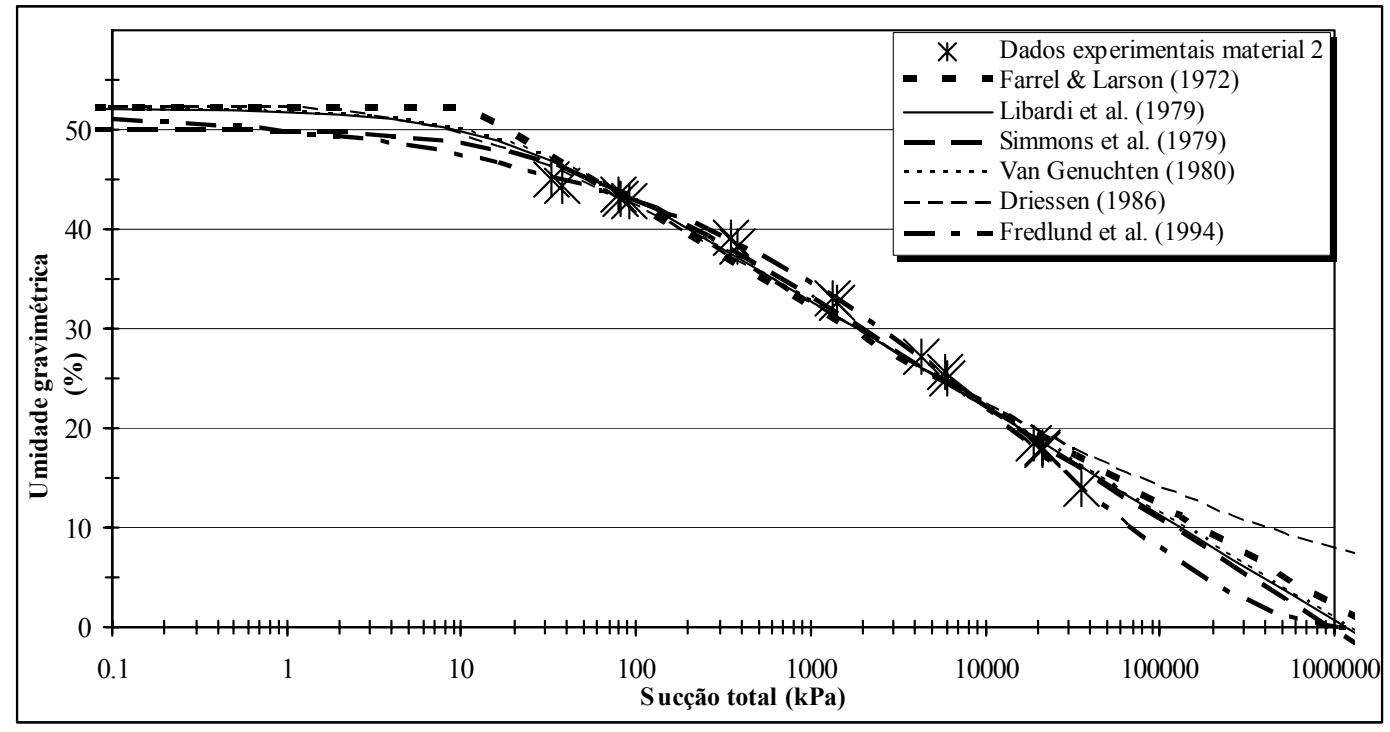

FIGURA 79. Curva de retenção para o material 2 (Papel Filtro).

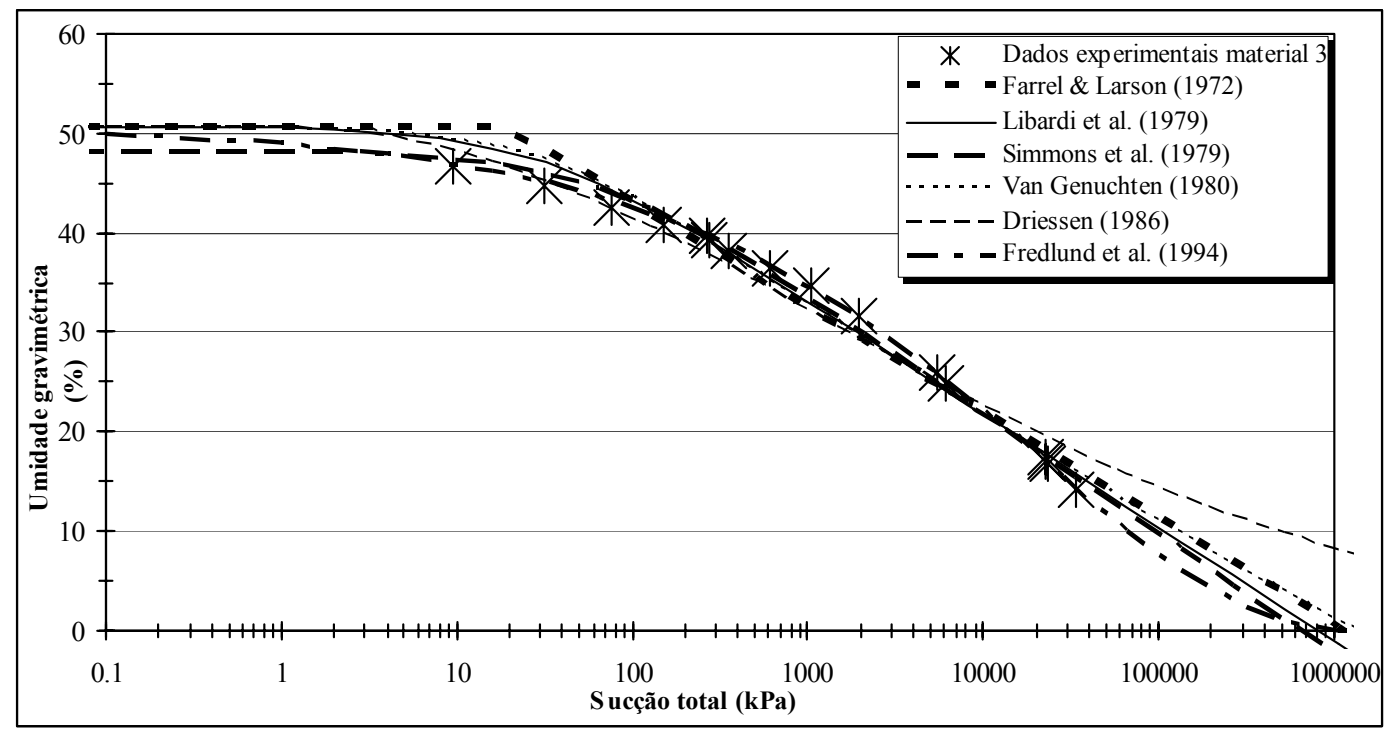

FIGURA 80. Curva de retenção para o material 3 (Papel Filtro). 


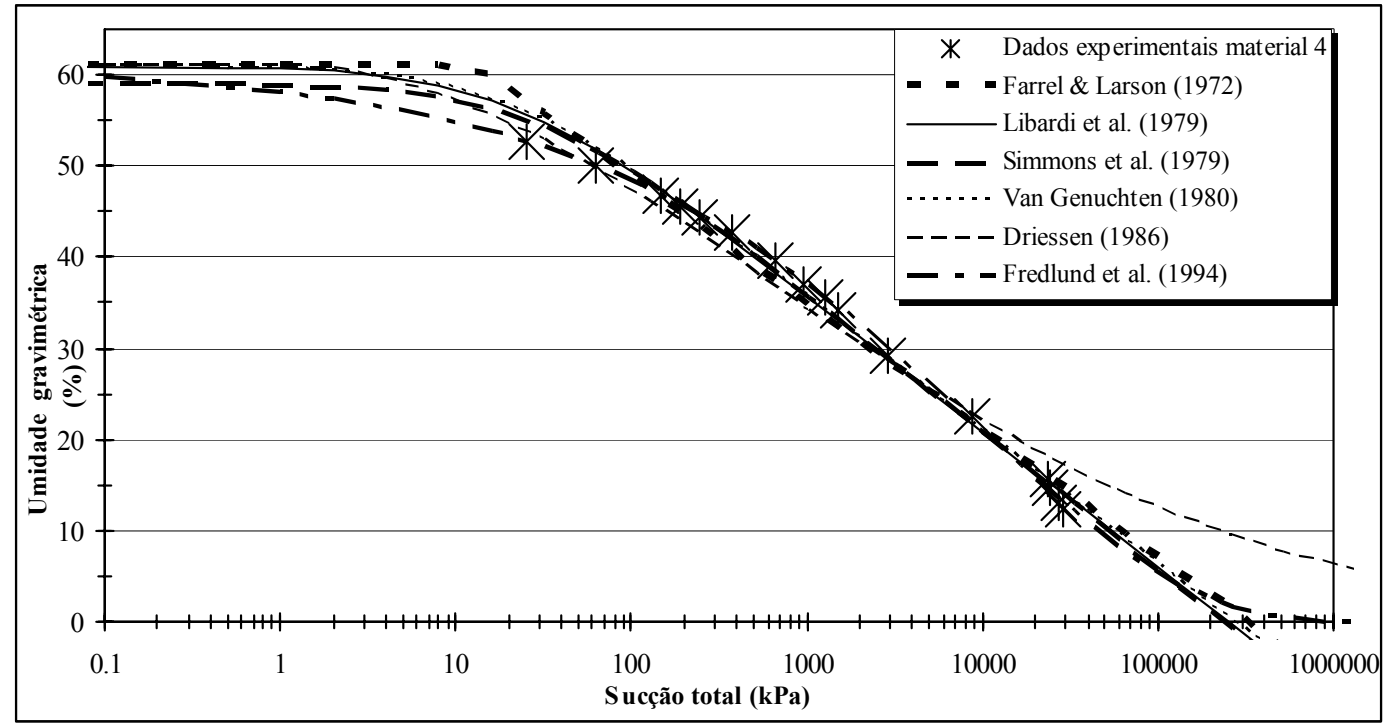

FIGURA 81. Curva de retenção para o material 4 (Papel Filtro).

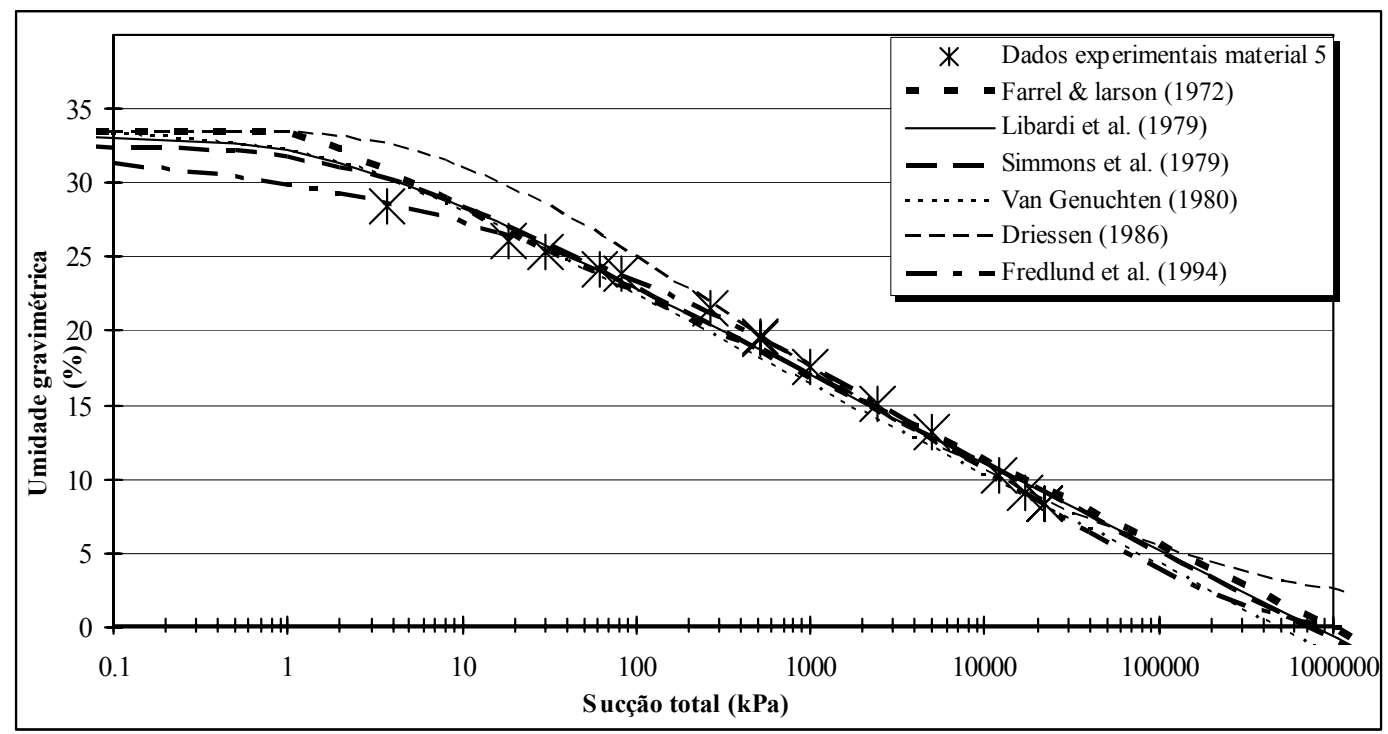

FIGURA 82. Curva de retenção para o material 5 (Papel Filtro).

Os parâmetros de ajuste das Curvas de Retenção para os valores experimentais gerados no ensaio de papel filtro (sucção total) podem ser observados nas Tabelas 24 , $25,26,27,28$ e 29. 
TABELA 24. Parâmetros de ajuste da Curva de Retenção através da equação matemática de Farrel \& Larson (1972)

\begin{tabular}{cccccc}
\hline $\begin{array}{c}\text { PARÂMETROS } \\
\text { Material }\end{array}$ & $\begin{array}{c}\mathrm{w}_{\mathrm{S}} \\
(\%)\end{array}$ & $\begin{array}{c}\psi_{\text {crit }} \\
(\mathrm{kPa})\end{array}$ & $\begin{array}{c}\mathrm{w}_{\mathrm{r}} \\
(\%)\end{array}$ & $\alpha$ & $\mathrm{r}^{2}$ \\
\hline 1 & 43,8 & 16,2971 & 7,8 & 7,6504 & 0,992 \\
2 & 52,1 & 10,8993 & 13,9 & 8,7392 & 0,982 \\
3 & 50,7 & 18,956 & 11,3 & 8,5782 & 0,974 \\
4 & 61,0 & 13,3428 & 12,3 & 8,0762 & 0,985 \\
5 & 33,4 & 1,2522 & 8,4 & 10,1368 & 0,986 \\
\hline
\end{tabular}

TABELA 25. Parâmetros de ajuste da Curva de Retenção através da equação matemática de Simmons, Nielsen \& Biggar (1979)

\begin{tabular}{ccccc}
\hline $\begin{array}{c}\text { PARÂMETROS } \\
\text { Material }\end{array}$ & $\begin{array}{c}\mathrm{w}_{\mathrm{S}} \\
(\boldsymbol{\%})\end{array}$ & $\alpha$ & $\beta$ & $\mathrm{r}^{2}$ \\
\hline 1 & 43,0 & 35,8039 & $-19,096$ & 0,998 \\
2 & 50,0 & 32,1903 & $-20,5208$ & 0,989 \\
3 & 48,3 & 62,5452 & $-19,1096$ & 0,991 \\
4 & 59,1 & 29,9935 & $-15,1732$ & 0,994 \\
5 & 32,7 & 2,3236 & $-38,6994$ & 0,990 \\
\hline
\end{tabular}

TABELA 26. Parâmetros de ajuste da Curva de Retenção através da equação matemática de Libardi et al. (1979)

\begin{tabular}{ccccc}
\hline $\begin{array}{c}\text { PARÂMETROS } \\
\text { Material }\end{array}$ & $\begin{array}{c}\mathrm{w}_{\mathrm{S}} \\
\mathbf{( \% )}\end{array}$ & $\alpha$ & $\beta$ & $\mathrm{r}^{2}$ \\
\hline 1 & 43,8 & 28,1394 & $-19,3996$ & 0,998 \\
2 & 52,1 & 16,4123 & $-21,3843$ & 0,987 \\
3 & 50,7 & 29,2959 & $-20,1723$ & 0,987 \\
4 & 61,0 & 20,1254 & $-15,4678$ & 0,993 \\
5 & 33,4 & 1,6469 & $-39,0852$ & 0,990 \\
\hline
\end{tabular}

TABELA 27. Parâmetros de ajuste da Curva de Retenção através da equação matemática de Van Genuchten (1980)

\begin{tabular}{ccccccc}
\hline $\begin{array}{c}\text { PARÂMETROS } \\
\text { Material }\end{array}$ & $\begin{array}{c}\mathrm{w}_{\mathrm{S}} \\
\left(\mathrm{cm}^{3} / \mathrm{cm}^{3}\right)\end{array}$ & $\begin{array}{c}\mathrm{W}_{\mathrm{r}} \\
\left(\mathrm{cm}^{3} / \mathrm{cm}^{3}\right)\end{array}$ & $\begin{array}{c}\alpha \\
(1 / \mathrm{kPa})\end{array}$ & $\mathrm{n}$ & $\mathrm{m}$ & $\mathrm{r}^{2}$ \\
\hline 1 & 0,438 & $-15,557$ & 0,0348 & 1,0033 & 0,0033 & 0,998 \\
2 & 0,521 & $-12,635$ & 0,0592 & 1,0036 & 0,0036 & 0,987 \\
3 & 0,507 & $-1,40$ & 0,0272 & 1,0294 & 0,0286 & 0,983 \\
4 & 0,610 & $-16,134$ & 0,0479 & 1,0039 & 0,0039 & 0,992 \\
5 & 0,334 & $-20,233$ & 0,596 & 1,0013 & 0,0013 & 0,990 \\
\hline
\end{tabular}

Os valores negativos de umidade gravimétrica residual (Tabela 27), foram obtidos através do ajuste dos dados experimentais e não apresentam significado físico. 
TABELA 28. Parâmetros de ajuste da Curva de Retenção através da equação matemática de Driessen (1986)

\begin{tabular}{cccc}
\hline $\begin{array}{c}\text { PARÂMETROS } \\
\text { Material }\end{array}$ & $\begin{array}{c}\mathrm{w}_{\mathrm{S}} \\
(\%)\end{array}$ & $\gamma$ & $\mathrm{r}^{2}$ \\
\hline 1 & 43,8 & 0,0126 & 0,964 \\
2 & 52,1 & 0,0099 & 0,982 \\
3 & 50,7 & 0,0095 & 0,971 \\
4 & 61,0 & 0,012 & 0,972 \\
5 & 33,4 & 0,0136 & 0,980 \\
\hline
\end{tabular}

TABELA 29. Parâmetros de ajuste da Curva de Retenção através da equação matemática de Fredlund et al. (1994)

\begin{tabular}{ccccccc}
\hline $\begin{array}{c}\text { PARÂMETROS } \\
\text { Material }\end{array}$ & $\begin{array}{c}\mathrm{W}_{\mathrm{S}} \\
\left(\mathrm{cm}^{3} / \mathrm{cm}^{3}\right)\end{array}$ & $\begin{array}{c}\psi_{\mathrm{r}} \\
(\mathrm{kPa})\end{array}$ & $\mathrm{a}$ & $\mathrm{n}$ & $\mathrm{m}$ & $\mathrm{r}^{2}$ \\
\hline 1 & 0,438 & $10^{6}$ & $2,12 \mathrm{E}+03$ & 0,51 & 2,641 & 0,999 \\
2 & 0,521 & $10^{6}$ & $6,57 \mathrm{E}+14$ & 0,313 & 5603,021 & 0,999 \\
3 & 0,507 & $10^{6}$ & $4,36 \mathrm{E}+14$ & 0,332 & 7615,298 & 0,999 \\
4 & 0,610 & $10^{6}$ & $6,08 \mathrm{E}+12$ & 0,331 & 2346,873 & 0,999 \\
5 & 0,334 & $10^{6}$ & $1,46 \mathrm{E}+17$ & 0,249 & 5812,917 & 0,999 \\
\hline
\end{tabular}

Nas Tabelas 30 e 31, podem ser observados os resultados experimentais dos ensaios de câmara de pressão para a determinação da curva de retenção e nas Figuras $83,84,85,86$ e 87 , os gráficos representativos destes dados. 

TABELA 30. Resultados experimentais obtidos no ensaio de câmara de pressão para os materiais 1,2 e 3

\begin{tabular}{|c|c|c|c|c|c|c|c|c|c|c|c|c|}
\hline $\begin{array}{c}\text { Corpo de } \\
\text { Prova } \\
\end{array}$ & 1 & 1.1 & 1.2 & & 2 & 2.1 & 2.2 & & 3 & 3.1 & 3.2 & \\
\hline$\psi_{\mathrm{m}}$ & W & W & W & $\mathrm{W}_{\text {média }}$ & W & W & W & $\mathrm{W}_{\text {média }}$ & W & W & W & $\mathrm{W}_{\text {média }}$ \\
\hline $\mathrm{kPa}$ & $\%$ & $\%$ & $\%$ & $\%$ & $\%$ & $\%$ & $\%$ & $\%$ & $\%$ & $\%$ & $\%$ & $\%$ \\
\hline 10 & 35,8 & 34,7 & 35,8 & 35,4 & 39,7 & 39,8 & 40,2 & 39,9 & 40,0 & 39,9 & 40,2 & 40,0 \\
\hline 50 & 33,6 & 32,5 & 33,8 & 33,3 & 36,1 & 36,3 & 36,7 & 36,4 & 37,8 & 37,8 & 38,1 & 37,9 \\
\hline 100 & 32,1 & 31,2 & 32,6 & 32,0 & 34,8 & 34,8 & 35,6 & 35,1 & 36,9 & 36,7 & 37,1 & 36,9 \\
\hline 300 & 30,0 & 29,3 & 30,8 & 30,1 & 34,2 & 34,3 & 35,0 & 34,5 & 36,3 & 36,3 & 36,6 & 36,4 \\
\hline 400 & 27,2 & 26,2 & 27,6 & 27,0 & 30,7 & 30,5 & 31,7 & 31,0 & 33,4 & 33,1 & 33,2 & 33,2 \\
\hline 600 & 24,4 & 23,7 & 24,9 & 24,3 & 30,0 & 29,7 & 31,1 & 30,3 & 32,4 & 32,1 & 32,1 & 32,2 \\
\hline 780 & 24,1 & 23,4 & 24,6 & 24,0 & 29,6 & 29,1 & 30,7 & 29,8 & 31,9 & 31,6 & 31,6 & 31,7 \\
\hline
\end{tabular}

TABELA 31. Resultados experimentais obtidos no ensaio de câmara de pressão para os materiais 4 e 5

\begin{tabular}{|c|c|c|c|c|c|c|c|c|}
\hline Corpo de Prova & 4 & 4.1 & 4.2 & & 5 & 5.1 & 5.2 & \\
\hline$\psi_{\mathrm{m}}$ & $\mathrm{w}$ & $\mathrm{w}$ & $\mathrm{w}$ & $\mathrm{W}_{\text {média }}$ & $\mathrm{w}$ & $\mathrm{w}$ & $\mathrm{W}$ & $\mathrm{W}_{\text {média }}$ \\
\hline $\mathrm{kPa}$ & $\%$ & $\%$ & $\%$ & $\%$ & $\%$ & $\%$ & $\%$ & $\%$ \\
\hline 10 & 45,2 & 44,3 & 43,7 & 44,4 & 22,9 & 24,2 & 22,6 & 23,2 \\
\hline 50 & 42,5 & 41,2 & 40,6 & 41,4 & 20,3 & 19,8 & 19,1 & 19,7 \\
\hline 100 & 39,5 & 38,3 & 37,5 & 38,4 & 18,3 & 17,3 & 16,7 & 17,5 \\
\hline 300 & 36,3 & 35,1 & 33,7 & 35,0 & 17,6 & 16,7 & 16,2 & 16,8 \\
\hline 400 & 33,6 & 32,1 & 31,0 & 32,2 & 15,8 & 15,4 & 14,8 & 15,4 \\
\hline 600 & 33,0 & 31,7 & 30,3 & 31,7 & 15,6 & 15,3 & 14,7 & 15,2 \\
\hline 780 & 32,0 & 30,7 & 30,0 & 30,9 & 15,3 & 15,1 & 14,5 & 15,0 \\
\hline
\end{tabular}




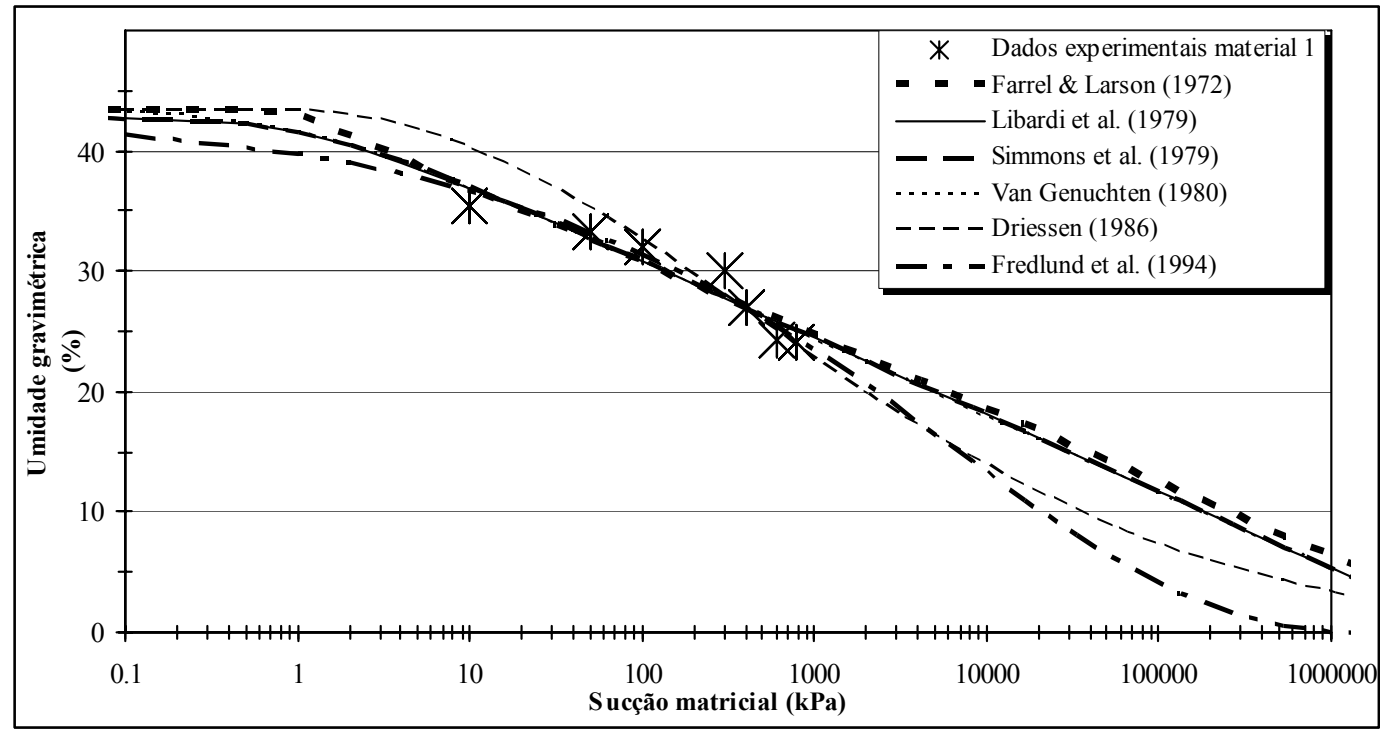

FIGURA 83. Curva de retenção para o material 1 (Câmara de Pressão).

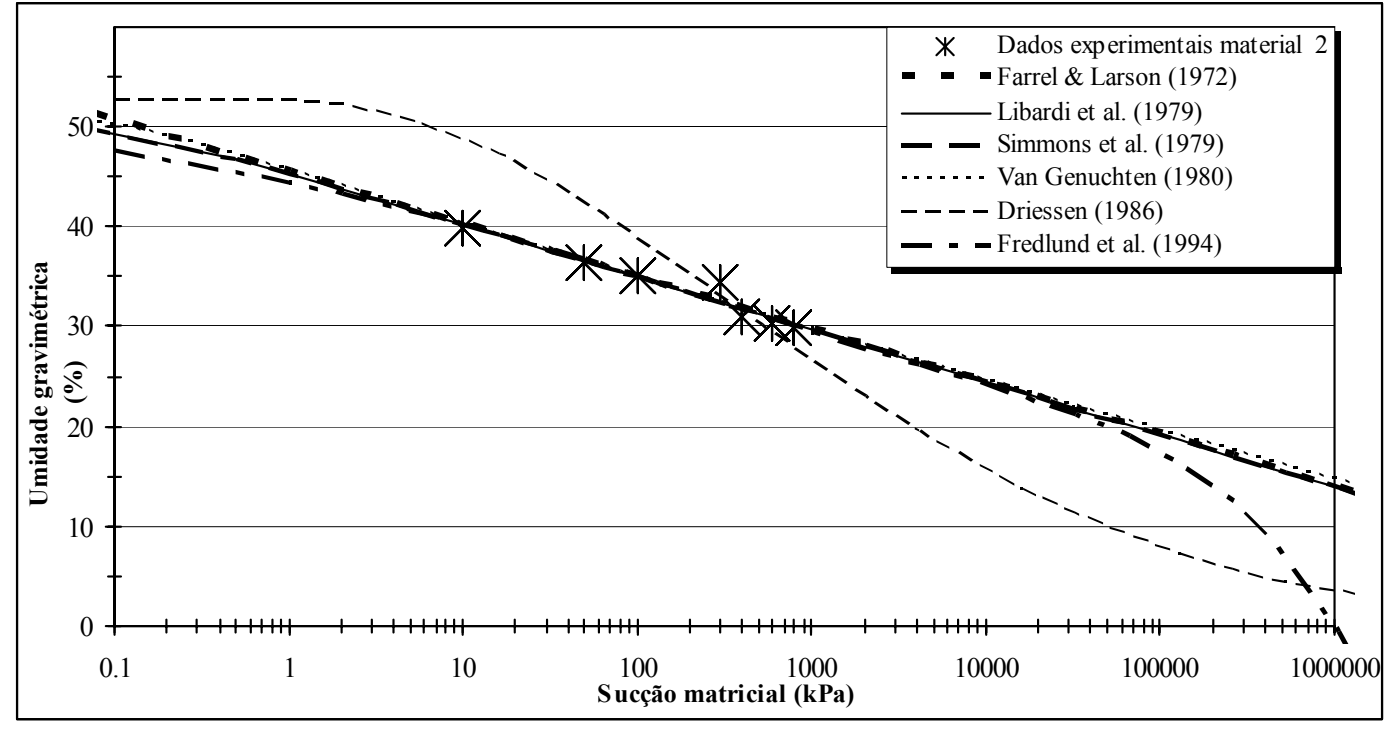

FIGURA 84. Curva de retenção para o material 2 (Câmara de Pressão). 


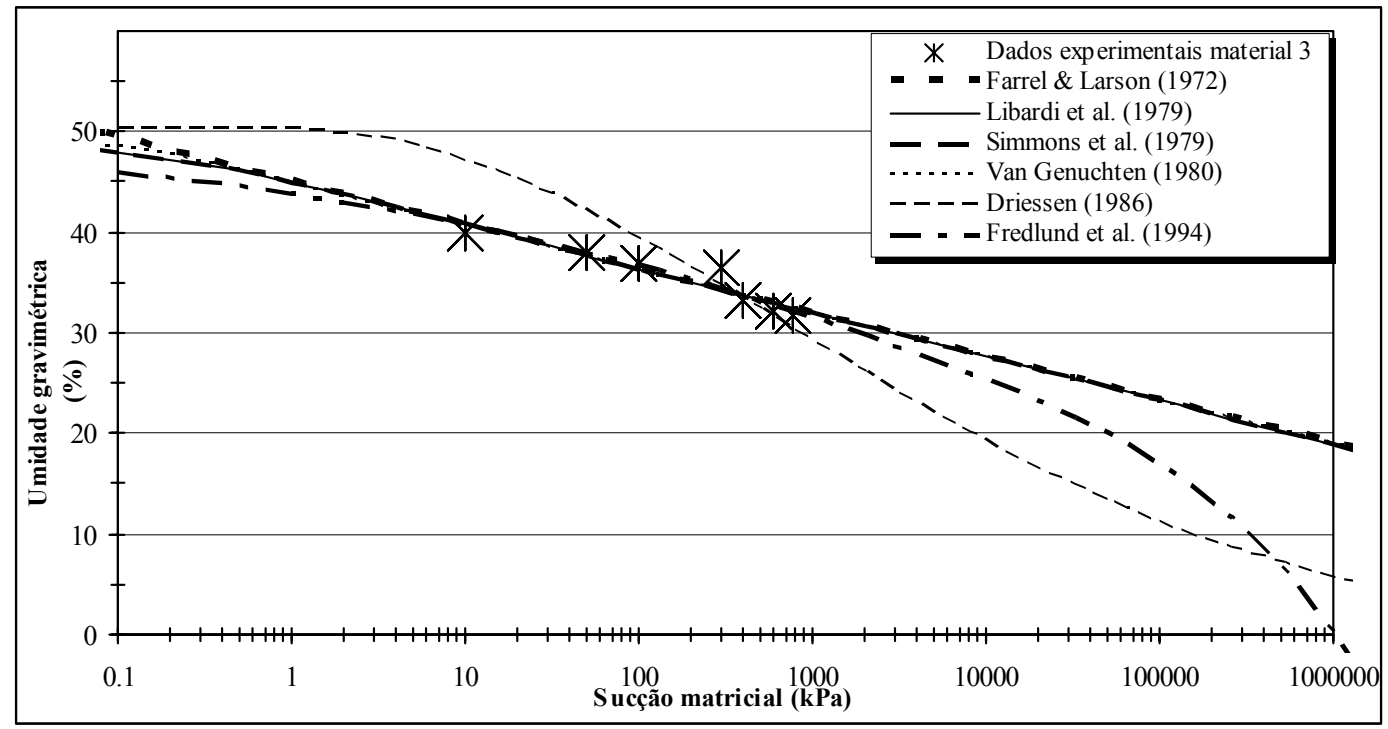

FIGURA 85. Curva de retenção para o material 3 (Câmara de Pressão).

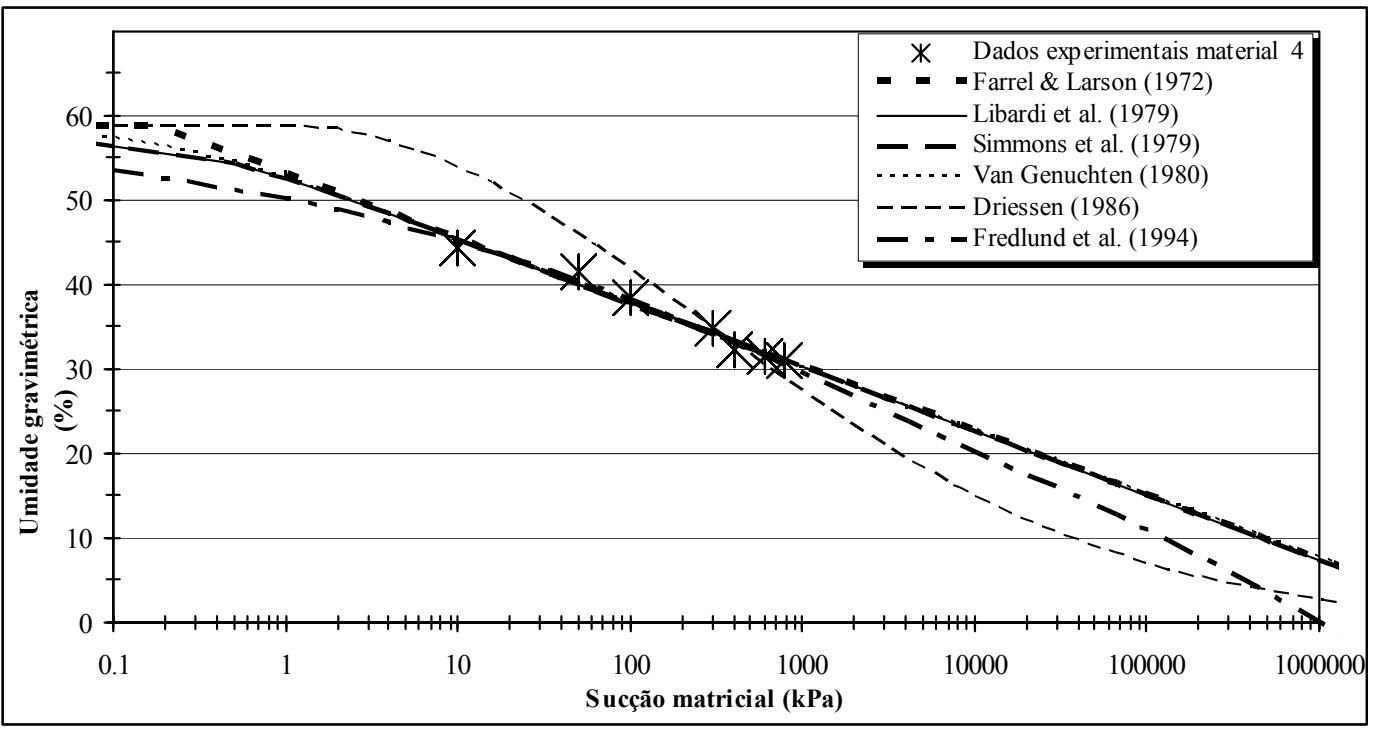

FIGURA 86. Curva de retenção para o material 4 (Câmara de Pressão). 


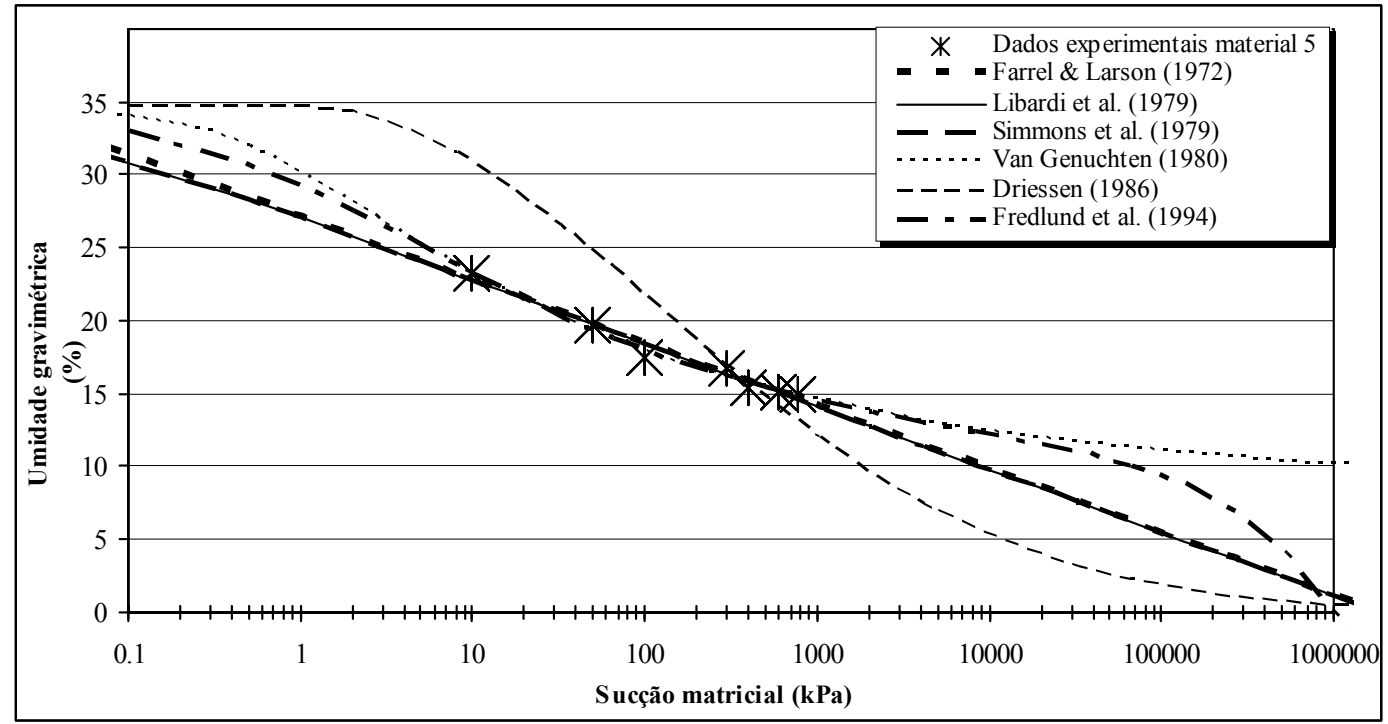

FIGURA 87. Curva de retenção para o material 5 (Câmara de Pressão).

Os parâmetros de ajuste das Curvas de Retenção para as equações 8 a 13 a partir dos dados experimentais gerados no ensaio da câmara de pressão (sucção matricial) podem ser observados nas Tabelas 32, 33, 34, 35, 36 e 37.

TABELA 32. Parâmetros de ajuste da Curva de Retenção através da equação matemática de Farrel \& Larson (1972)

\begin{tabular}{cccccc}
\hline $\begin{array}{c}\text { PARÂMETROS } \\
\text { Materiais }\end{array}$ & $\begin{array}{c}\mathrm{w}_{\mathrm{S}} \\
(\%)\end{array}$ & $\begin{array}{c}\psi_{\text {crit }} \\
(\mathrm{kPa})\end{array}$ & $\begin{array}{c}\mathrm{w}_{\mathrm{r}} \\
(\%)\end{array}$ & $\alpha$ & $\mathrm{r}^{2}$ \\
\hline 1 & 43,3 & 0,8908 & 24,1 & 7,2245 & 0,952 \\
2 & 52,6 & 0,0434 & 29,8 & 10,0103 & 0,986 \\
3 & 50,2 & 0,0658 & 31,7 & 9,8115 & 0,973 \\
4 & 58,8 & 0,173 & 30,8 & 8,4877 & 0,992 \\
5 & 34,7 & 0,0175 & 0 & 18,4605 & 0,981 \\
\hline
\end{tabular}

TABELA 33. Parâmetros de ajuste da Curva de Retenção através da equação matemática de Simmons, Nielsen \& Biggar (1979)

\begin{tabular}{ccccc}
\hline $\begin{array}{c}\text { PARÂMETROS } \\
\text { Material }\end{array}$ & $\begin{array}{c}\mathrm{W}_{\mathrm{S}} \\
\left(\mathrm{cm}^{3} / \mathrm{cm}^{3}\right)\end{array}$ & $\alpha$ & $\beta$ & $\mathrm{r}^{2}$ \\
\hline 1 & 43,2 & 1,2024 & $-35,9439$ & 0,955 \\
2 & 52,6 & 0,0439 & $-43,8012$ & 0,986 \\
3 & 50,2 & 0,0676 & $-52,8179$ & 0,973 \\
4 & 58,8 & 0,1814 & $-30,1887$ & 0,992 \\
5 & 34,7 & 0,0175 & $-53,1933$ & 0,995 \\
\hline
\end{tabular}


TABELA 34. Parâmetros de ajuste da Curva de Retenção através da equação matemática de Libardi et al. (1979)

\begin{tabular}{ccccc}
\hline $\begin{array}{c}\text { PARÂMETROS } \\
\text { Material }\end{array}$ & $\begin{array}{c}\mathrm{w}_{\mathrm{S}} \\
(\%)\end{array}$ & $\alpha$ & $\beta$ & $\mathrm{r}^{2}$ \\
\hline 1 & 43,3 & 1,1303 & $-36,0271$ & 0,954 \\
2 & 52,6 & 0,0438 & $-43,8012$ & 0,986 \\
3 & 50,2 & 0,0675 & $-52,8124$ & 0,973 \\
4 & 58,8 & 0,1807 & $-30,1893$ & 0,992 \\
5 & 34,7 & 0,0175 & $-53,1933$ & 0,995 \\
\hline
\end{tabular}

TABELA 35. Parâmetros de ajuste da Curva de Retenção através da equação matemática de Van Genuchten (1980)

\begin{tabular}{ccccccc}
\hline $\begin{array}{c}\text { PARÂMETROS } \\
\text { Material }\end{array}$ & $\begin{array}{c}\mathrm{W}_{\mathrm{S}} \\
\left(\mathrm{cm}^{3} / \mathrm{cm}^{3}\right)\end{array}$ & $\begin{array}{c}\mathrm{W}_{\mathrm{r}} \\
\left(\mathrm{cm}^{3} / \mathrm{cm}^{3}\right)\end{array}$ & $\begin{array}{c}\alpha \\
(1 / \mathrm{kPa})\end{array}$ & $\mathrm{n}$ & $\mathrm{m}$ & $\mathrm{r}^{2}$ \\
\hline 1 & 0,433 & $-11,3490$ & 0,8680 & 1,0024 & 0,0024 & 0,954 \\
2 & 0,526 & $-2,029$ & 15,5649 & 1,0097 & 0,0096 & 0,986 \\
3 & 0,502 & $-7,236$ & 13,9131 & 1,0025 & 0,0025 & 0,973 \\
4 & 0,588 & $-13,374$ & 5,305 & 1,0024 & 0,0024 & 0,992 \\
5 & 0,347 & 0,086 & 1,9318 & 1,1938 & 0,1623 & 0,997 \\
\hline
\end{tabular}

Os resultados negativos de umidade gravimétrica residual (Tabela 35), não possuem significado físico, no entanto, foram utilizados apenas para a obtenção do ajuste da curva de retenção.

TABELA 36. Parâmetros de ajuste da Curva de Retenção através da equação matemática de Driessen (1986)

\begin{tabular}{cccc}
\hline $\begin{array}{c}\text { PARÂMETROS } \\
\text { Material }\end{array}$ & $\begin{array}{c}\mathrm{w}_{\mathrm{S}} \\
(\%)\end{array}$ & $\gamma$ & $\mathrm{r}^{2}$ \\
\hline 1 & 43,3 & 0,0134 & 0,928 \\
2 & 52,6 & 0,0143 & 0,796 \\
3 & 50,2 & 0,0113 & 0,821 \\
4 & 58,8 & 0,0161 & 0,856 \\
5 & 34,7 & 0,0222 & 0,787 \\
\hline
\end{tabular}

TABELA 37. Parâmetros de ajuste da Curva de Retenção através da equação matemática de Fredlund et al. (1994)

\begin{tabular}{ccccccc}
\hline $\begin{array}{c}\text { PARÂMETROS } \\
\text { Material }\end{array}$ & $\begin{array}{c}\mathrm{W}_{\mathrm{S}} \\
\left(\mathrm{cm}^{3} / \mathrm{cm}^{3}\right)\end{array}$ & $\begin{array}{c}\psi_{\mathrm{r}} \\
(\mathrm{kPa})\end{array}$ & $\mathrm{a}$ & $\mathrm{n}$ & $\mathrm{m}$ & $\mathrm{r}^{2}$ \\
\hline 1 & 0,433 & $10^{6}$ & $9,80 \mathrm{E}+14$ & 0,28 & 3802,641 & 0,974 \\
2 & 0,526 & $10^{6}$ & 11,709 & 0,257 & 1,011 & 0,986 \\
3 & 0,502 & $10^{6}$ & 12134,627 & 0,199 & 2,528 & 0,977 \\
4 & 0,587 & $10^{6}$ & 11399,012 & 0,233 & 3,932 & 0,995 \\
5 & 0,347 & $10^{6}$ & 0,867 & 0,62 & 0,584 & 0,997 \\
\hline
\end{tabular}


Nas Tabelas 38, 39, 40, 41 e 42 e nas Figuras 88, 89, 90, 91 e 92, são mostrados os resultados da variação de volume das amostras em função do aumento da sucção imposta dentro da câmara de pressão.

TABELA 38. Resultados para amostras do material 1

\begin{tabular}{|c|c|c|c|c|c|c|c|c|c|}
\hline \multicolumn{10}{|c|}{ MATERIAL 1} \\
\hline Amostra & $\begin{array}{l}\text { Sucção } \\
\text { matricial } \\
(\mathrm{kPa})\end{array}$ & $\begin{array}{l}\text { Volume } \\
\left(\mathrm{cm}^{3}\right)\end{array}$ & $\begin{array}{c}\text { Contração } \\
(\%)\end{array}$ & Amostra & $\begin{array}{c}\text { Volume } \\
\left(\mathrm{cm}^{3}\right)\end{array}$ & $\begin{array}{c}\text { Contração } \\
(\%)\end{array}$ & Amostra & $\begin{array}{l}\text { Volume } \\
\left(\mathrm{cm}^{3}\right)\end{array}$ & $\begin{array}{c}\text { Contração } \\
(\%)\end{array}$ \\
\hline \multirow{7}{*}{1} & 10 & 22,03 & 0 & \multirow{7}{*}{1.1} & 22,28 & 0 & \multirow{7}{*}{1.2} & 21,90 & 0 \\
\hline & 50 & 22,03 & 0 & & 22,28 & 0 & & 21,90 & 0 \\
\hline & 100 & 22,03 & 0 & & 22,28 & 0 & & 21,90 & 0 \\
\hline & 300 & 19,67 & 10,7 & & 22,28 & 0 & & 21,90 & 0 \\
\hline & 400 & 19,60 & 11,0 & & 22,28 & 0 & & 20,18 & 7,9 \\
\hline & 600 & 19,24 & 12,7 & & 20,33 & 8,8 & & 19,35 & 11,6 \\
\hline & 780 & 18,65 & 15,3 & & 19,00 & 14,7 & & 18,57 & 15,2 \\
\hline
\end{tabular}

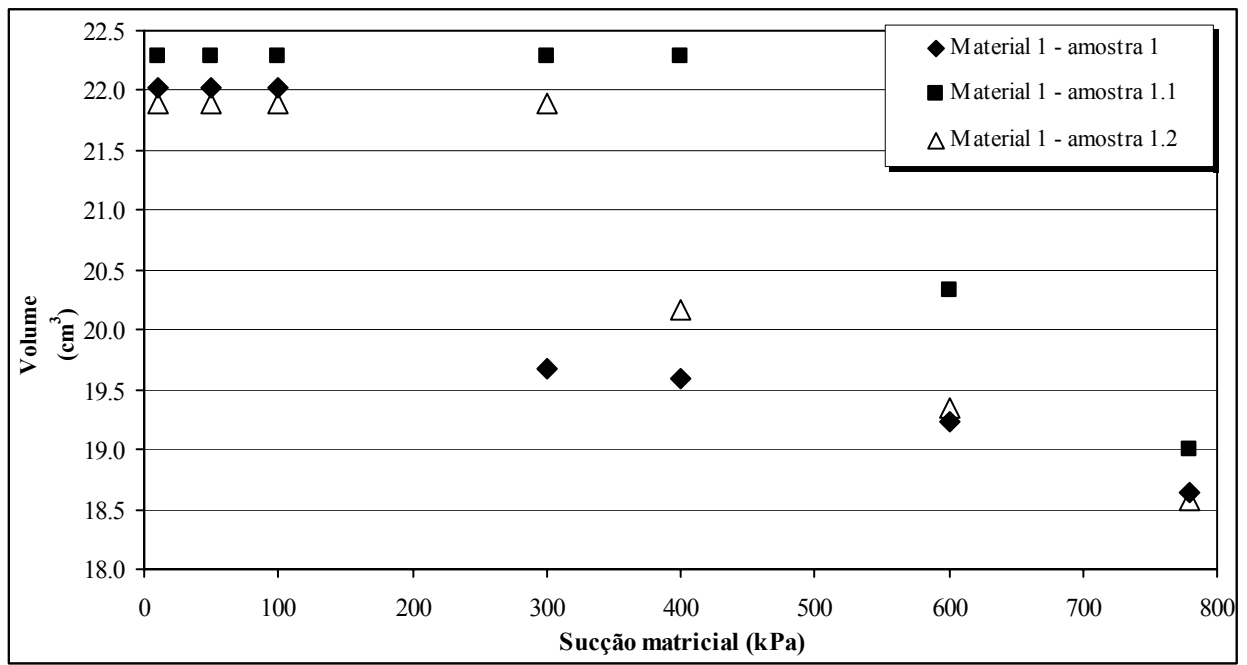

FIGURA 88. Representação dos dados de Variação de volume e Sucção matricial para o material 1.

TABELA 39. Resultados para amostras do material 2

\begin{tabular}{|c|c|c|c|c|c|c|c|c|c|}
\hline \multicolumn{10}{|c|}{ MATERIAL 2} \\
\hline Amostra & $\begin{array}{c}\text { Sucção } \\
\text { matricial } \\
(\mathrm{kPa})\end{array}$ & $\begin{array}{c}\text { Volume } \\
\left(\mathrm{cm}^{3}\right)\end{array}$ & $\begin{array}{c}\text { Contração } \\
(\%)\end{array}$ & Amostra & $\begin{array}{c}\text { Volume } \\
\left(\mathrm{cm}^{3}\right)\end{array}$ & $\begin{array}{c}\text { Contração } \\
(\%)\end{array}$ & Amostra & $\begin{array}{c}\text { Volume } \\
\left(\mathrm{cm}^{3}\right)\end{array}$ & $\begin{array}{c}\text { Contração } \\
(\%)\end{array}$ \\
\hline \multirow{7}{*}{2} & 10 & 21,76 & 0 & \multirow{7}{*}{2.1} & 22,37 & 0 & \multirow{7}{*}{2.2} & 22,01 & 0 \\
\hline & 50 & 21,76 & 0 & & 22,37 & 0 & & 22,01 & 0 \\
\hline & 100 & 21,76 & 0 & & 22,37 & 0 & & 22,01 & 0 \\
\hline & 300 & 21,76 & 0 & & 20,52 & 8,3 & & 20,84 & 5,3 \\
\hline & 400 & 21,76 & 0 & & 20,00 & 10,6 & & 20,62 & 6,3 \\
\hline & 600 & 19,50 & 10,4 & & 19,61 & 12,3 & & 19,79 & 10,1 \\
\hline & 780 & 19,22 & 11,7 & & 19,41 & 13,2 & & 19,22 & 12,7 \\
\hline
\end{tabular}




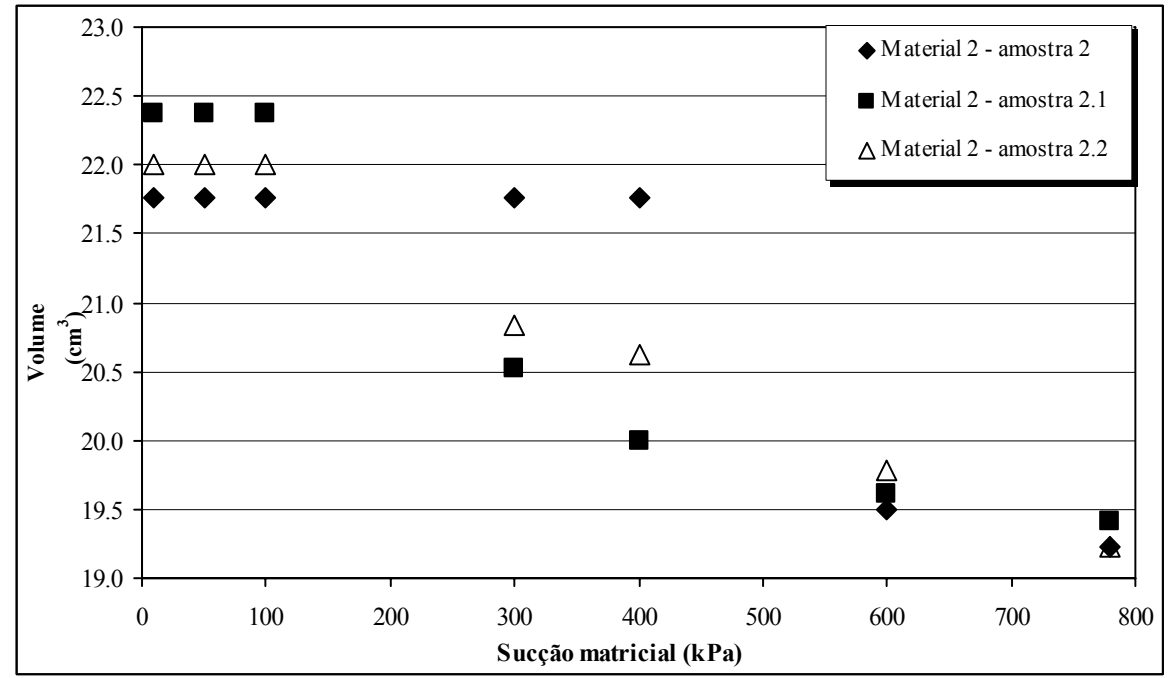

FIGURA 89. Representação dos dados de Variação de volume e Sucção matricial para o material 2.

TABELA 40. Resultados para amostras do material 3

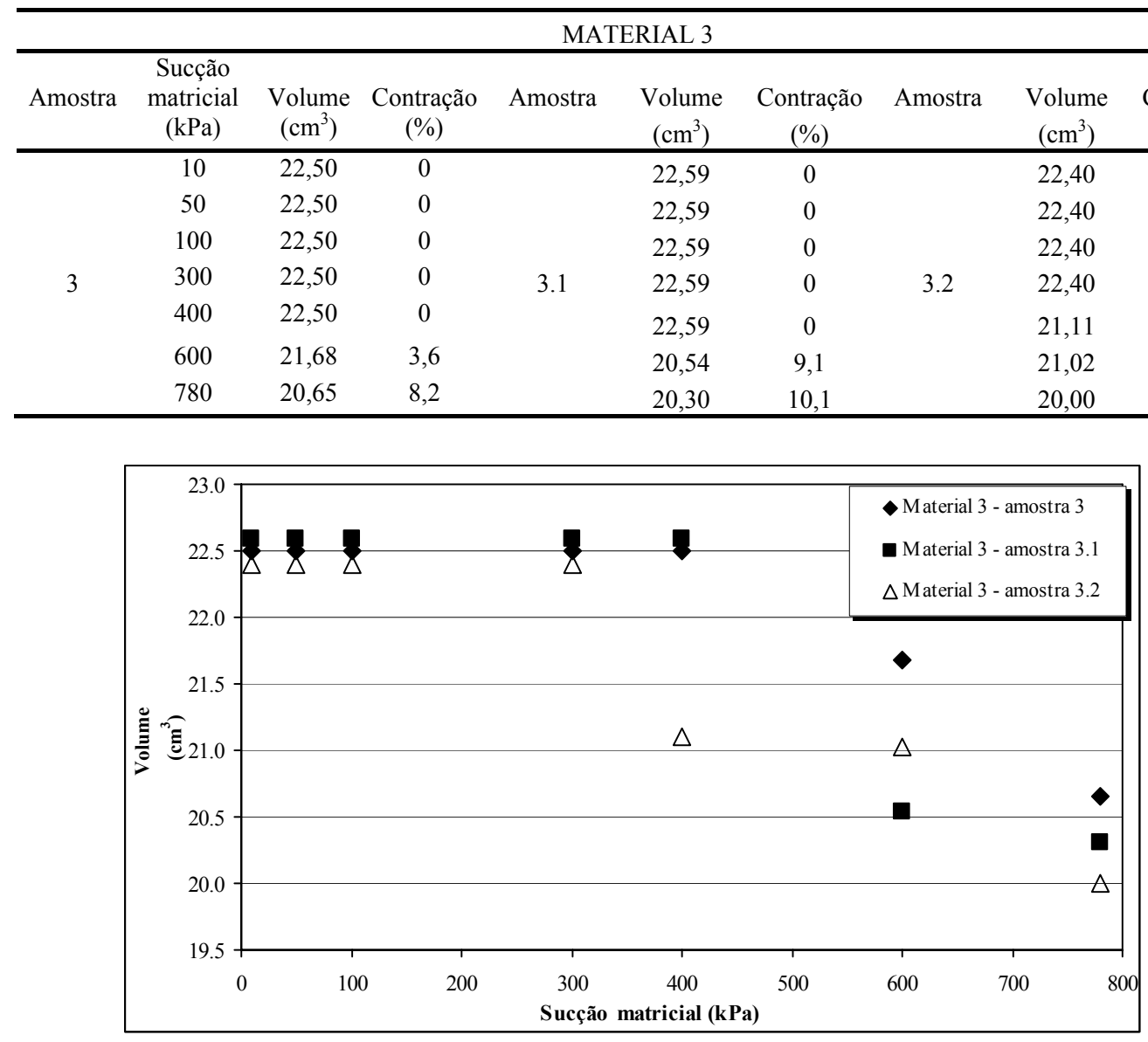

FIGURA 90. Representação dos dados de Variação de volume e Sucção matricial para o material 3. 
TABELA 41. Resultados para amostras do material 4

\begin{tabular}{|c|c|c|c|c|c|c|c|c|c|}
\hline \multicolumn{10}{|c|}{ MATERIAL 4} \\
\hline Amostra & $\begin{array}{c}\text { Sucção } \\
\text { matricial } \\
(\mathrm{kPa})\end{array}$ & $\begin{array}{c}\text { Volume } \\
\left(\mathrm{cm}^{3}\right)\end{array}$ & $\begin{array}{c}\text { Contração } \\
(\%)\end{array}$ & Amostra & $\begin{array}{c}\text { Volume } \\
\left(\mathrm{cm}^{3}\right)\end{array}$ & $\begin{array}{c}\text { Contração } \\
(\%)\end{array}$ & Amostra & $\begin{array}{c}\text { Volume } \\
\left(\mathrm{cm}^{3}\right)\end{array}$ & $\begin{array}{c}\text { Contração } \\
(\%)\end{array}$ \\
\hline \multirow{7}{*}{4} & 10 & 21,84 & 0 & \multirow{7}{*}{4.1} & 21,90 & 0 & \multirow{7}{*}{4.2} & 22,06 & 0 \\
\hline & 50 & 21,84 & 0 & & 21,90 & 0 & & 22,06 & 0 \\
\hline & 100 & 21,84 & 0 & & 21,90 & 0 & & 22,06 & 0 \\
\hline & 300 & 21,84 & 0 & & 21,90 & 0 & & 22,06 & 0 \\
\hline & 400 & 21,68 & 0,70 & & 21,73 & 0,78 & & 20,29 & 8,0 \\
\hline & 600 & 19,08 & 12,6 & & 17,96 & 17,99 & & 17,00 & 22,9 \\
\hline & 780 & 18,25 & 16,4 & & 17,25 & 21,23 & & 16,13 & 26,9 \\
\hline
\end{tabular}

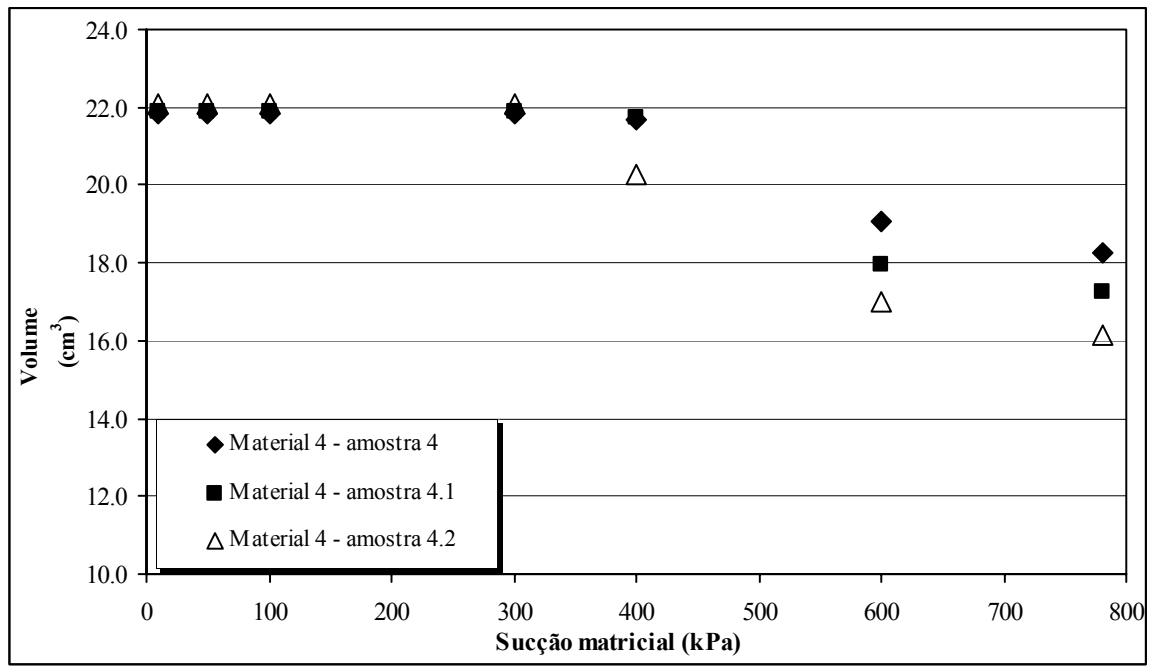

FIGURA 91. Representação dos dados de Variação de volume e Sucção matricial para o material 4.

TABELA 42. Resultados para amostras do material 5

\begin{tabular}{|c|c|c|c|c|c|c|c|c|c|}
\hline \multicolumn{10}{|c|}{ MATERIAL 5} \\
\hline Amostra & $\begin{array}{l}\text { Sucção } \\
\text { matricial } \\
(\mathrm{kPa})\end{array}$ & $\begin{array}{l}\text { Volume } \\
\left(\mathrm{cm}^{3}\right)\end{array}$ & $\begin{array}{c}\text { Contração } \\
(\%)\end{array}$ & Amostra & $\begin{array}{l}\text { Volume } \\
\left(\mathrm{cm}^{3}\right)\end{array}$ & $\begin{array}{c}\text { Contração } \\
(\%)\end{array}$ & Amostra & $\begin{array}{l}\text { Volume } \\
\left(\mathrm{cm}^{3}\right)\end{array}$ & $\begin{array}{c}\text { Contração } \\
(\%)\end{array}$ \\
\hline \multirow{7}{*}{5} & 10 & 22,37 & 0 & \multirow{7}{*}{5.1} & 22,01 & 0 & \multirow{7}{*}{5.2} & 23,15 & 0 \\
\hline & 50 & 22,37 & 0 & & 22,01 & 0 & & 23,15 & 0 \\
\hline & 100 & 22,37 & 0 & & 22,01 & 0 & & 23,15 & 0 \\
\hline & 300 & 22,37 & 0 & & 22,01 & 0 & & 23,15 & 0 \\
\hline & 400 & 22,37 & 0 & & 22,01 & 0 & & 23,15 & 0 \\
\hline & 600 & 22,37 & 0 & & 22,01 & 0 & & 23,15 & 0 \\
\hline & 780 & 21,84 & 2,4 & & 21,16 & 3,9 & & 23,15 & 0 \\
\hline
\end{tabular}




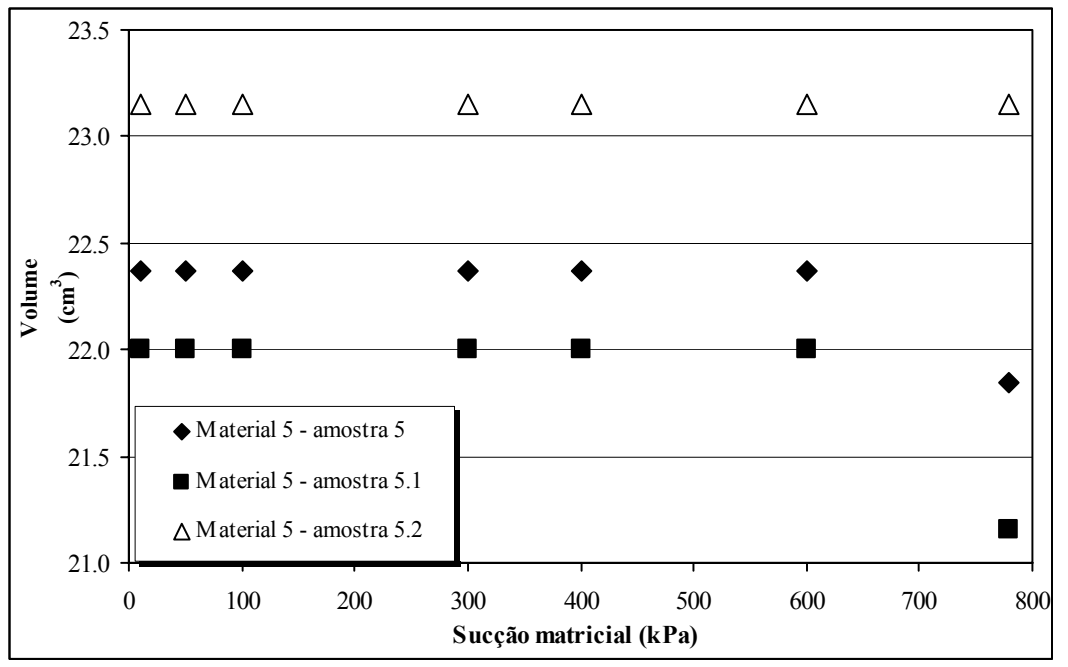

FIGURA 92. Representação dos dados de Variação de volume e Sucção matricial para o material 5.

As variações de volumes médias para os materiais 1, 2, 3, 4 e 5 foram de 15,07; 12,$53 ; 9,67 ; 21,51$ e $2,10 \%$, respectivamente. Destes resultados, observa-se que o material 4, apresentou uma redução de cerca de $1 / 5$ em seu volume inicial para a sucção máxima aplicada $(780 \mathrm{kPa})$, que foi a mais significativa em relação aos materiais com porcentagem da fração argila superior a $50 \%$, sendo que, o material 5, mais arenoso, foi o que sofreu a menor contração.

\subsubsection{Análise dos resultados dos ajustes das curvas de retenção}

Como já mostrado anteriormente, os dados experimentais de umidade gravimétrica e sucção matricial (Tabelas 14 e 15 e 30 e 31), obtidos para os cinco materiais pelas técnicas do Papel Filtro e Câmara de Pressão foram ajustados por seis modelos matemáticos (equações 8 a 13). Inicialmente, com o objetivo de verificar qual modelo melhor representava os materiais argilosos da Formação Guabirotuba, fez-se uma comparação entre os coeficientes de determinação $\left(\mathrm{r}^{2}\right)$ provenientes de cada curva de ajuste. Como pode ser visto nas Figuras 73 a 77 e 83 a 87, em alguns casos, apesar do coeficiente de determinação ser próximo a 1, resolveu-se testar a qualidade dos ajustes para os resultados provenientes dos dois métodos de ensaio (papel filtro e câmara de pressão), a partir do denominado erro padrão de estimativa $(\varepsilon)$, definido 
como o somatório do quadrado dos resíduos, dividido pelo número de determinações consideradas menos dois, que é dado pela expressão (Spiegel, 1969):

$\varepsilon=\sqrt{\frac{\sum\left(\mathrm{w}-\mathrm{w}_{\text {prev. }}\right)^{2}}{\mathrm{n}-2}}$

Onde: $\mathrm{w}=$ umidade gravimétrica medida e $\mathrm{w}_{\text {prev. }}=$ umidade gravimétrica prevista (a partir da curva de ajuste) e $n=$ total de pontos experimentais.

De acordo com Spiegel (1969), alguns estatísticos consideram conveniente utilizar a expressão 26 com o denominador n-2, visto que, é uma correção do número total de amostras (n), sendo mais representativo do erro quando trata-se da análise de pequenas amostras, o que deve favorecer uma determinação mais precisa em relação aos dados de curva de retenção aqui avaliados.

As Tabelas 43 e 44 mostram os erros no ajuste das curvas de retenção para os cinco materiais estudados.

TABELA 43. Resultados dos erros de estimativa obtidos para o método da Câmara de Pressão (sucção matricial)

\section{Método da Câmara de Pressão}

\begin{tabular}{cccccc}
\hline & \multicolumn{5}{c}{$\varepsilon$} \\
\cline { 2 - 6 } Autores & \multicolumn{5}{c}{ Materiais } \\
\cline { 2 - 6 } & 1 & 2 & 3 & 4 & 5 \\
\hline Farrel \& Larson (1972) & 2,69 & 1,10 & 1,35 & 0,98 & 0,36 \\
Simmons, Nielsen \& Biggar (1979) & 2,56 & 1,09 & 1,35 & 0,97 & 0,36 \\
Libardi et al. (1979) & 2,55 & 1,09 & 1,34 & 0,96 & 0,36 \\
Van Genuchten (1980) & 2,55 & 1,08 & 1,38 & 0,96 & 0,20 \\
Driessen (1986) & 6,61 & 26,80 & 16,57 & 26,10 & 21,20 \\
Fredlund et al. (1994) & 1,51 & 1,06 & 1,11 & 0,59 & 0,20 \\
\hline
\end{tabular}

Observando as curvas de ajuste para os dados dos ensaios de papel filtro (Figuras 73 a 77) foi possível verificar que o modelo de Fredlund et al. (1994) ajusta-se melhor aos valores experimentais para os cinco materiais, o que é evidenciado a partir dos coeficientes de determinação $\left(\mathrm{r}^{2}\right)$ que estão muito próximos a 1 e confirmado pela análise de estimativa de erro. Os demais modelos apresentaram deficiências ou para 
valores de baixa sucção mais próximos às umidades de saturação do material ou para altos valores de sucção.

TABELA 44. Resultados dos erros de estimativa obtidos para o método do Papel Filtro (sucção matricial)

\begin{tabular}{cccccc}
\hline Método do Papel Filtro & \multicolumn{5}{c}{$\varepsilon$} \\
\cline { 2 - 6 } & \multicolumn{5}{c}{ Materiais } \\
\cline { 2 - 6 } Autores & 1 & 2 & 3 & 4 & 5 \\
\hline Farrel \& Larson (1972) & 1,90 & 5,06 & 5,99 & 4,90 & 0,40 \\
Simmons, Nielsen \& Biggar (1979) & 0,18 & 0,95 & 0,93 & 1,60 & 0,34 \\
Libardi et al. (1979) & 0,46 & 3,33 & 4,50 & 2,97 & 0,35 \\
Van Genuchten (1980) & 0,55 & 3,62 & 4,77 & 3,15 & 0,65 \\
Driessen (1986) & 0,93 & 5,27 & 6,87 & 6,86 & 5,88 \\
Fredlund et al. (1994) & 0,06 & 0,34 & 0,68 & 0,41 & 0,05 \\
\hline
\end{tabular}

Observa-se a partir dos gráficos representativos dos ensaios da câmara de pressão (Figuras 83 a 87) que as curvas de ajuste a partir do modelo de Fredlund et al. (1994), de igual forma, ajustam-se melhor aos valores experimentais para os cinco materiais.

As Tabelas 43 e 44 mostram que erros de estimativa situam-se numa faixa de 0,05 a 26,8 e que de forma geral, ocorre um maior erro nos ajustes das curvas obtidas para a Técnica da Câmara de Pressão se comparados com a Técnica do Papel Filtro, devido provavelmente ao número reduzido de pontos experimentais obtidos a partir do primeiro método.

Para ambos os métodos, a proposição matemática de Fredlund et al. (1994) apresentou os melhores resultados e ,portanto, a melhor qualidade nos ajustes, e a de Driessen (1986), os maiores erros na modelagem das curvas de ajuste.

\subsubsection{Comparação dos resultados obtidos pelas técnicas da Câmara de Pressão e do Papel Filtro}

Com o propósito de analisar as técnicas da Câmara de Pressão (Sucção Matricial) e Papel Filtro (Sucção Matricial e Total), são mostradas abaixo as curvas de retenção, realizadas pelo processo de secagem para os materiais 3 e 5, que são representativas dos demais materiais. Para que os dados experimentais obtidos de cada material pudessem ser visualizados em conjunto, optou-se por colocá-los num mesmo gráfico (Figuras 93 e 94), onde já estão representadas as curvas de ajuste geradas mediante regressões não 
lineares, a partir do modelo matemático de Fredlund et al. (1994). Cabe ressaltar que decidiu-se utilizar este modelo, porque foi o que apresentou um melhor ajuste para os materiais argilosos, como já explicado no item anterior.

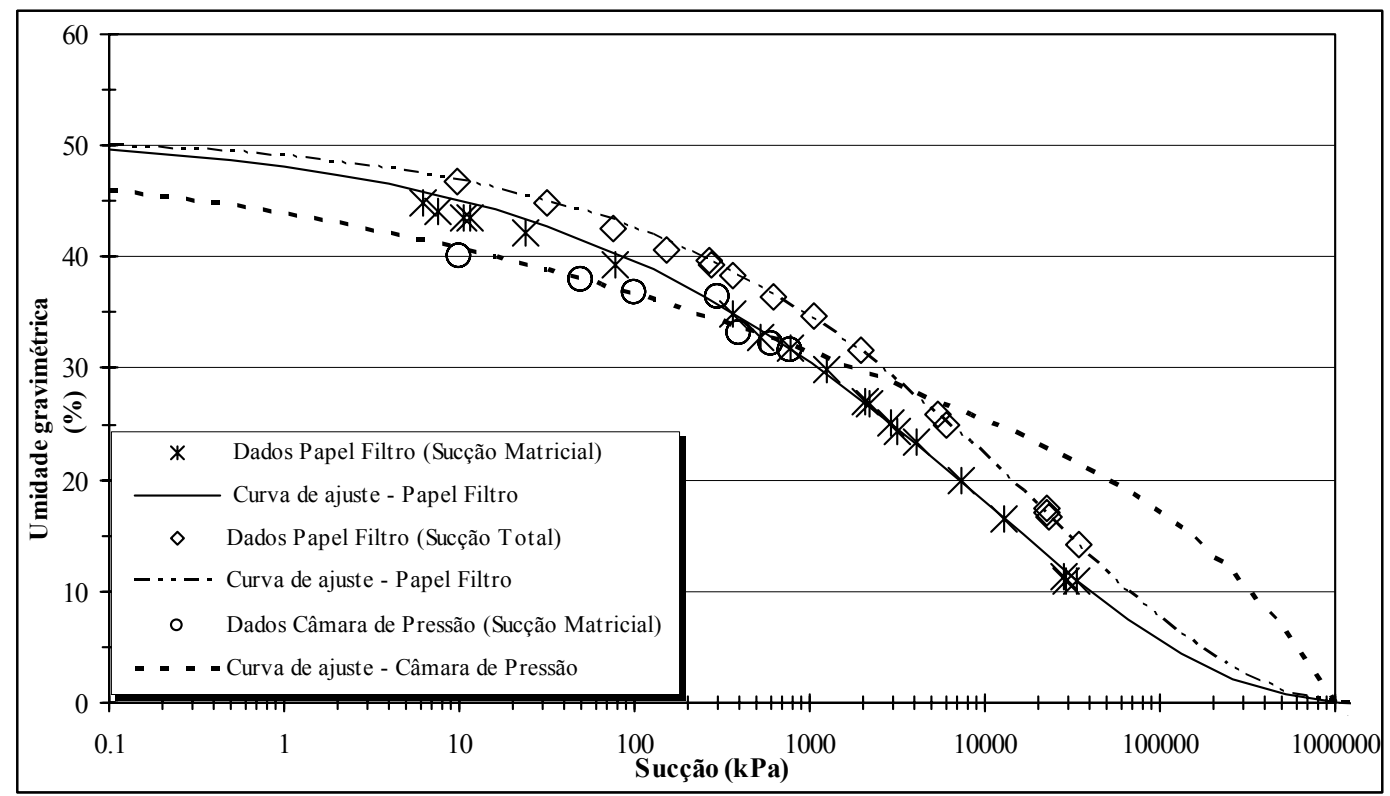

FIGURA 93. Curvas de retenção para amostras do material 3.

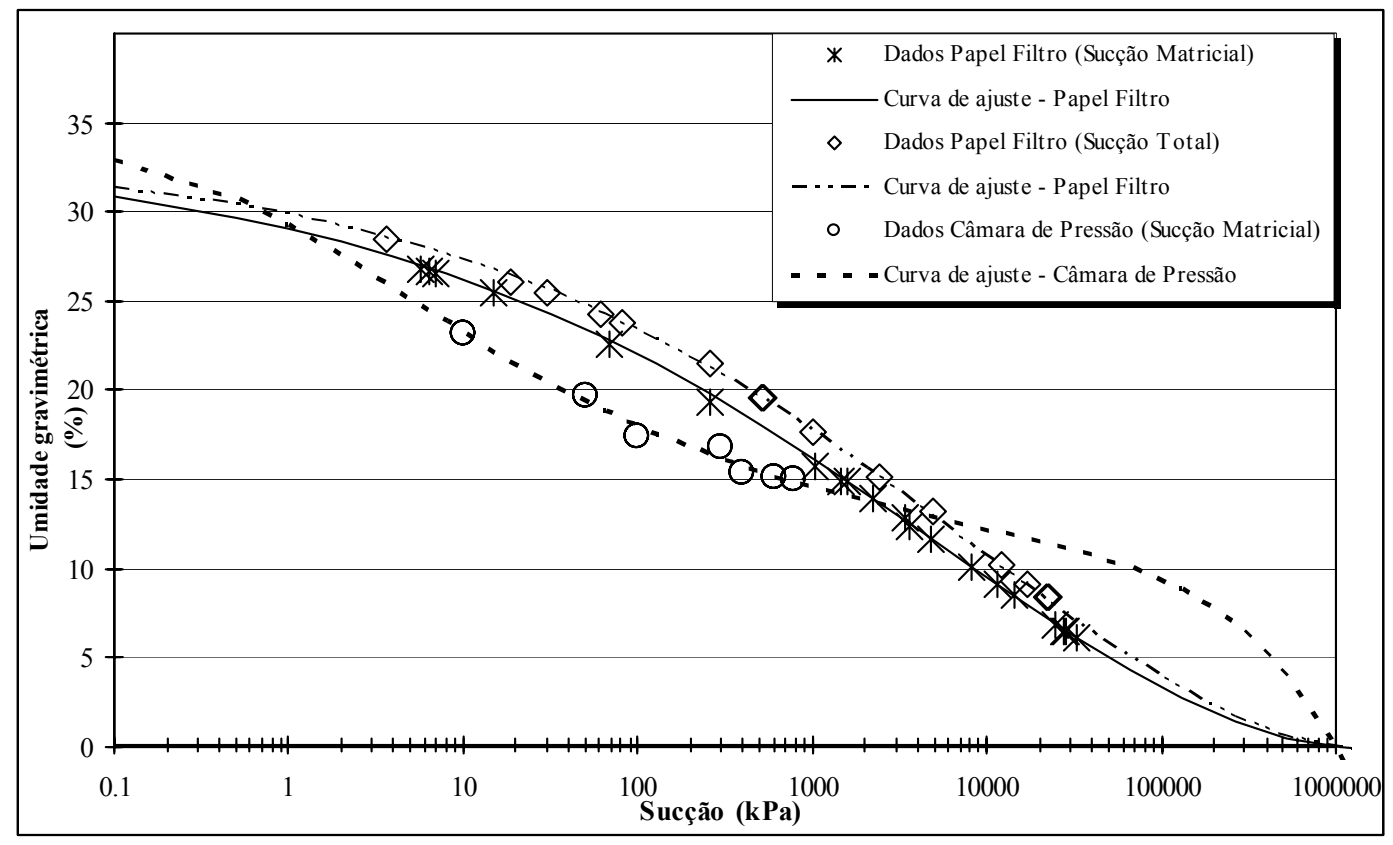

FIGURA 94. Curvas de retenção para amostras do material 5. 
Quanto aos dados experimentais para as duas técnicas, pode-se dizer que para todos os materiais, os resultados da técnica da câmara de pressão (Figuras 83 a 87) em relação aos do papel filtro (Figuras 73 a 77) para a determinação da sucção matricial foram mais baixos. Não se encontraram justificativas plausíveis para esse comportamento.

Nas curvas de ajuste para os resultados da câmara de pressão (Figuras 83 a 87) é evidente a necessidade de dados em toda sua extensão, sendo que a falta de valores para as sucções mais elevadas descaracteriza a forma da curva, que deveria ser sigmoidal. Desta forma, os ajustes para os dados experimentais do papel filtro (matricial e total), representam melhor a forma típica da curva para materiais argilosos.

Os valores de sucção total foram superiores aos de sucção matricial, mostrando coerência, já que na primeira está incorporada a parcela de sucção osmótica (Figuras 93 e 94).

Observando-se todas as curvas de variação de umidade em função da sucção verifica-se que para um mesmo valor de sucção, os materiais com maior porcentagem da fração argila, apresentam maior retenção de água, do que os que possuem uma maior porcentagem de areia. Esta constatação pode ser visualizada nas Figuras 93 e 94, onde estão representadas as curvas para os materiais 3 e 5, compostos por 78 e $30 \%$ de argila respectivamente.

Analisando os dados experimentais em relação aos dados gerados através dos ajustes, pode-se observar que para a Técnica do Papel Filtro (Tabelas 14 e 15, e Tabelas 22 e 23), os valores estão mais próximos aos experimentais, se comparado com a Técnica da Câmara de Pressão (Tabelas 30 e 31). Os coeficientes de determinação $\left(\mathrm{r}^{2}\right.$ ) dos ajustes para a Câmara de Pressão (Tabelas 32 a 37) são menores para todos os materiais em relação aos provenientes do ensaio do Papel Filtro (Tabelas 16 a 21 e 24 a 29). O ensaio do papel filtro apresenta uma melhor seqüência de dados (evidenciado pelo menor erro de estimativa em relação à câmara de pressão) e adicionalmente se observou no procedimento melhor versatilidade do ensaio devido ao menor tempo de realização do mesmo.

De forma geral, pode-se dizer que a Técnica do Papel Filtro se apresentou como a alternativa mais adequada para a determinação da Curva de Retenção dos materiais analisados da Formação Guabirotuba. Por se tratar de materiais argilosos, havia a necessidade da utilização de um método com o qual fossem determinadas sucções elevadas, sendo que esta técnica permitiu alcançar este propósito. Além disso, o ensaio é 
relativamente rápido em relação a outros métodos e pode ser facilmente realizado, porque não necessita de equipamento especial como é o caso da câmara de pressão. No entanto, deve-se levar em consideração alguns cuidados, como por exemplo, quanto ao contato da amostra com o papel filtro (sucção matricial) e com o ganho de umidade dos papéis de filtro após a retirada da estufa para a determinação do teor de umidade (o que pode levar a valores de sucção errôneos).

Quanto à determinação da sucção matricial a partir do método da Câmara de Pressão, deve-se ressaltar que neste caso, o tempo de equilíbrio para cada sucção foi extremamente demorado, além do que, o limite de sucção que pode ser alcançado a partir da técnica da translação de eixos é de $10.000 \mathrm{kPa}$, sendo que, no presente estudo, foi necessário a obtenção de uma faixa de sucção superior a esta, o que pode ser realizado pelo método do Papel filtro.

\subsubsection{Determinação da Sucção Osmótica}

Nas Figuras 95 a 99, são mostradas as curvas de retenção (sucção matricial e total versus umidade gravimétrica) para cada material, obtidas pelo método do papel filtro e ajustadas pela equação 13. Cabe ressaltar que decidiu-se utilizar esta equação visto o melhor ajuste, evidenciados pelos coeficientes de determinação $\left(\mathrm{r}^{2}\right)$ obtidos (Tabelas 21 e 29).

Como era esperado, observou-se que em todos os casos a sucção total é maior que a matricial para o mesmo valor de umidade e isto ocorre na faixa onde os dados experimentais podem ser comparados. 


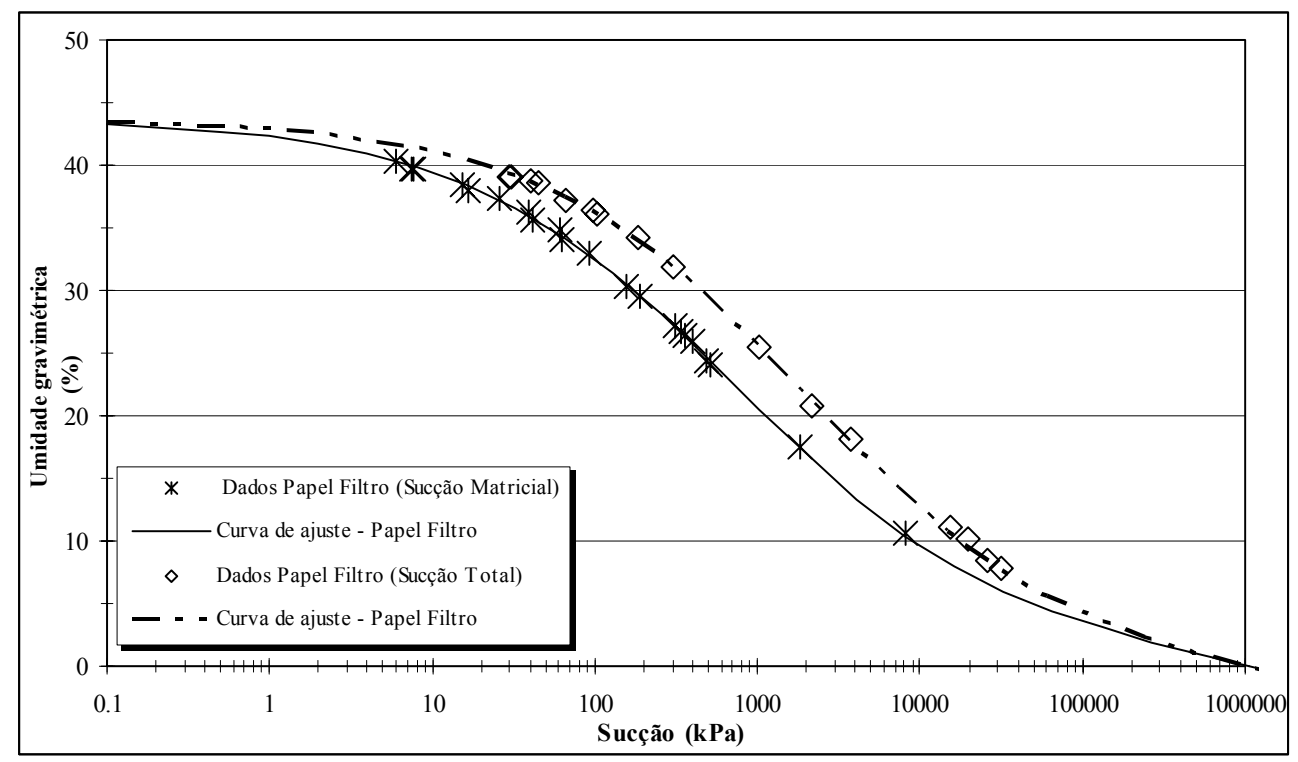

FIGURA 95. Curvas de retenção obtidas para o material 1 (Papel Filtro).

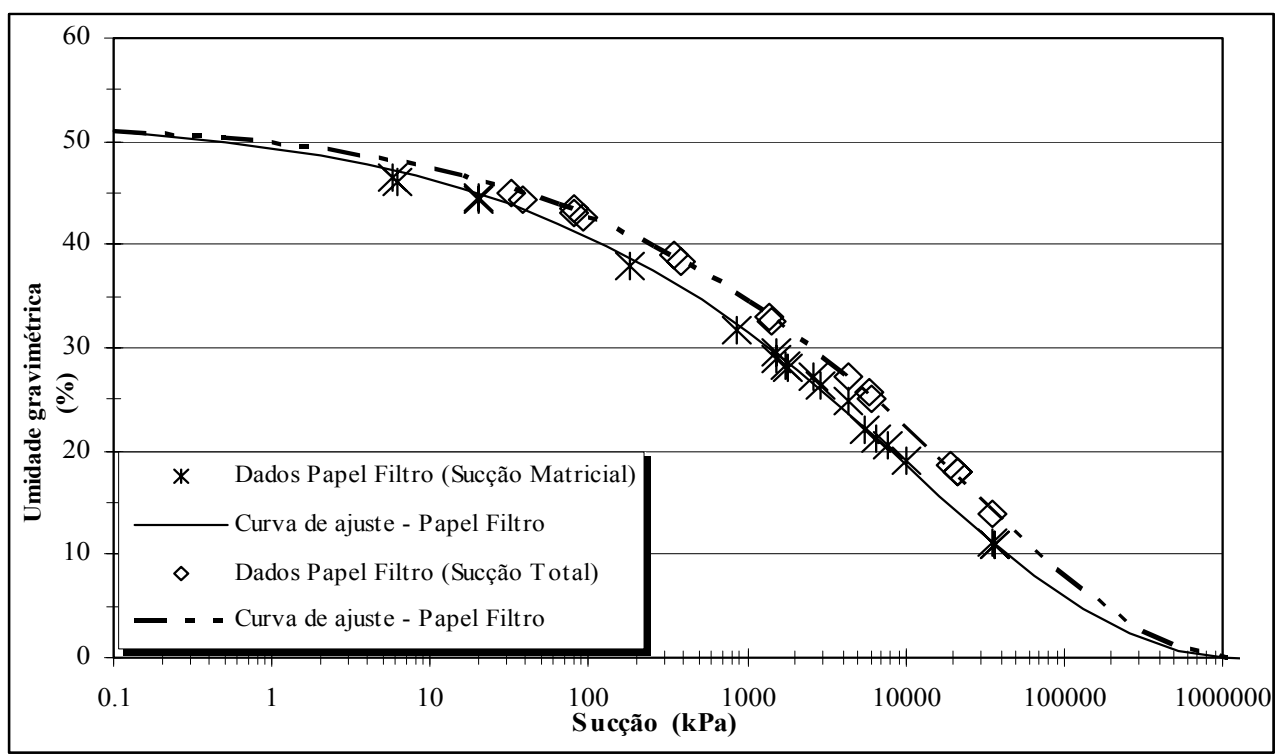

FIGURA 96. Curvas de retenção obtidas para o material 2 (Papel Filtro). 


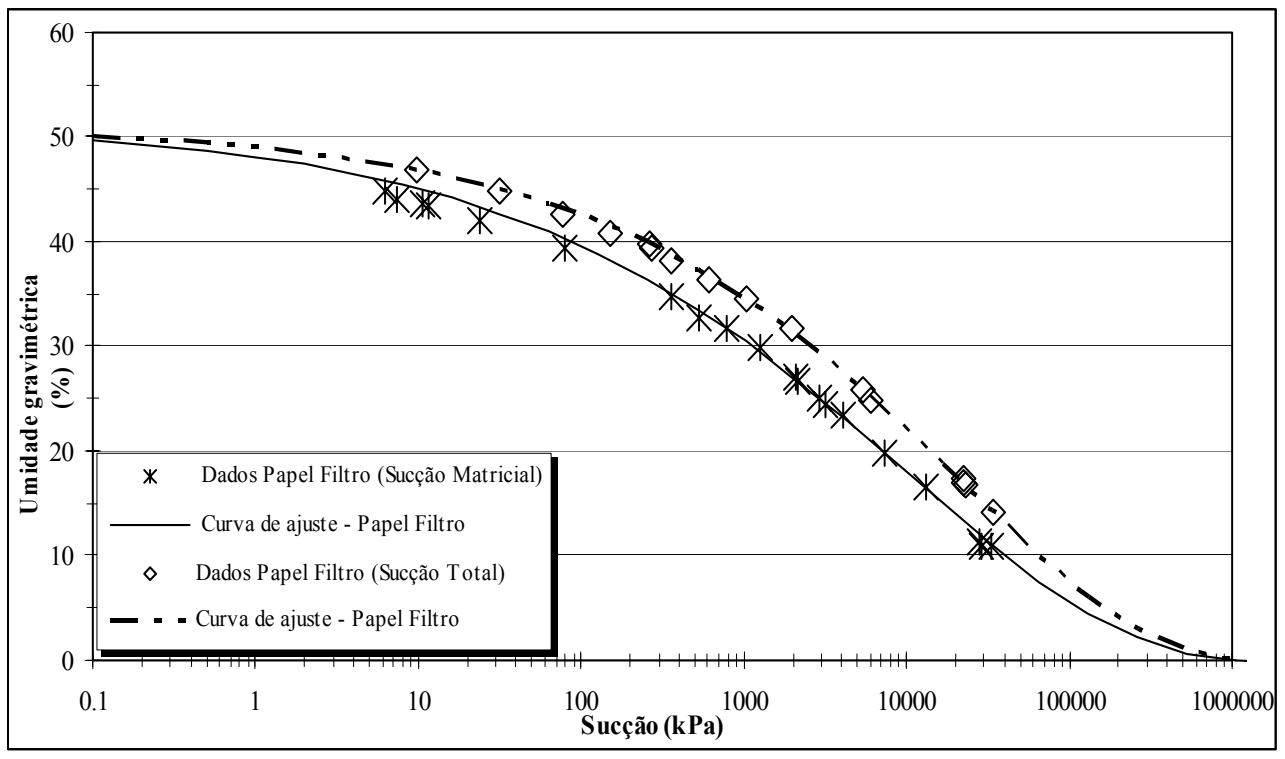

FIGURA 97. Curvas de retenção obtidas para o material 3 (Papel Filtro).

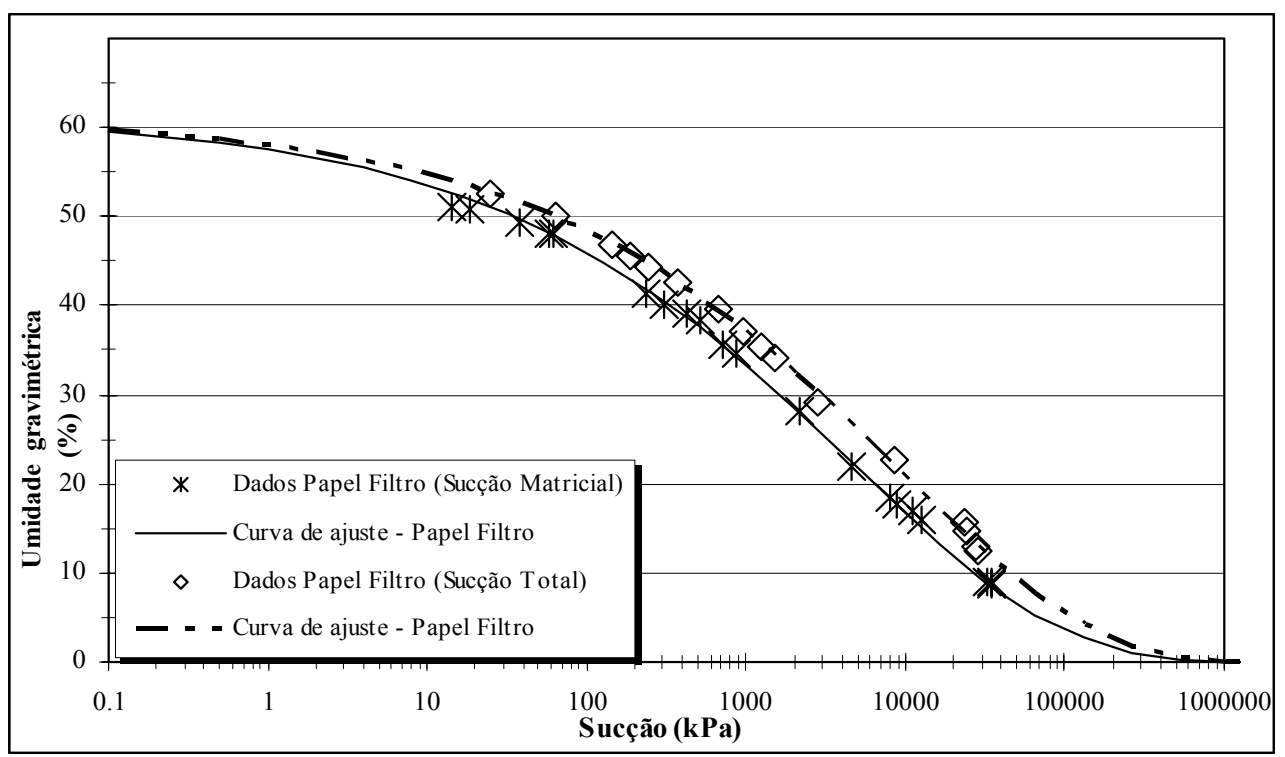

FIGURA 98. Curvas de retenção obtidas para o material 4 (Papel Filtro). 


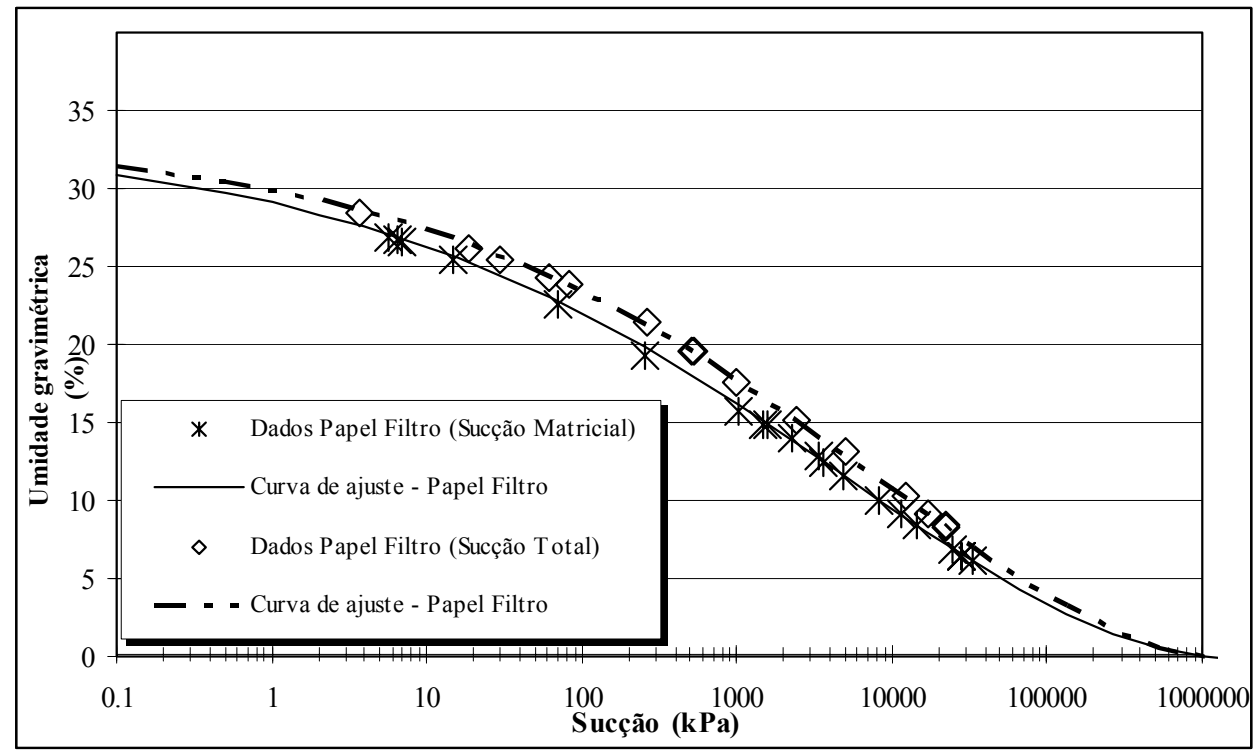

FIGURA 99. Curvas de retenção obtidas para o material 5 (Papel Filtro).

A sucção osmótica foi determinada pela diferença entre os dados de sucção matricial e total obtidos através do método do papel filtro, mostradas nas Figuras 95 a 99 e são representadas na Figura 100, expresso como sucção osmótica e umidade gravimétrica normalizada. No entanto, cada valor obtido nessa figura corresponde à diferença entre a sucção total (experimental) menos a sucção matricial (ajustada) ou vice-versa para um determinado teor de umidade. Não foram utilizados dados ajustados que fossem extrapolados, isto para não incluir valores que pudessem conduzir a erros de estimativa.

A utilização da umidade gravimétrica normalizada ao invés de umidade gravimétrica neste gráfico se deveu a que, os teores de saturação de cada material são diferentes, o que prejudicaria a comparação da sucção osmótica para um mesmo valor de umidade. A transformação foi realizada com auxílio da expressão 27 (Fredlund, 2002):

$\mathrm{W}_{\text {normalizada }}=\frac{\mathrm{W}-\mathrm{w}_{\mathrm{f}}}{\mathrm{W}_{\mathrm{i}}-\mathrm{w}_{\mathrm{f}}}$

Onde: $\mathrm{w}=$ umidade gravimétrica $(\%)$ correspondente a cada valor de sucção osmótica; $\mathrm{W}_{\mathrm{f}}=$ umidade gravimétrica final $(\%)$ e $\mathrm{w}_{\mathrm{i}}=$ umidade gravimétrica inicial (\%). 


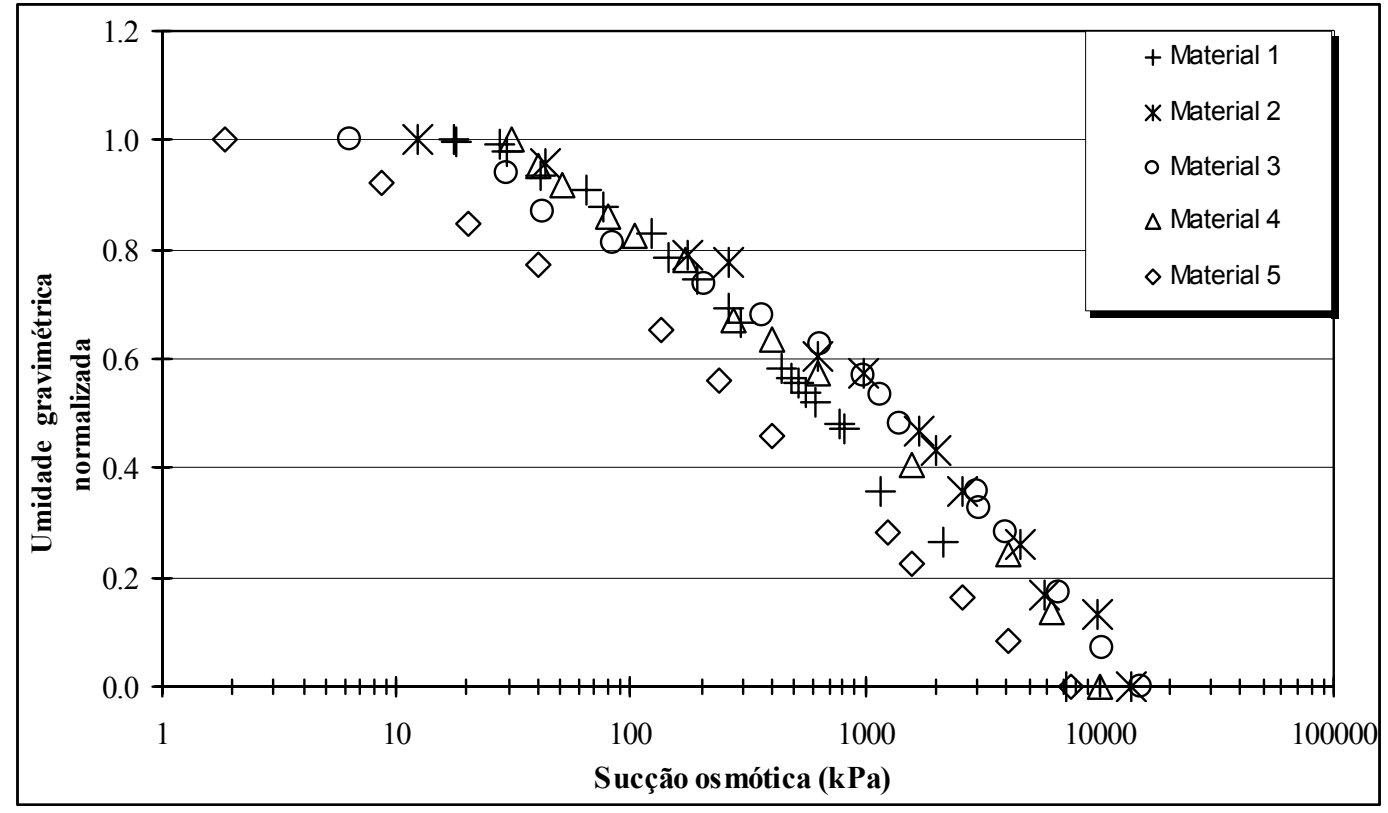

FIGURA 100. Representação dos dados de umidade gravimétrica normalizada e sucção osmótica $(\mathrm{kPa})$ para os cinco materiais.

Observa-se na Figura 100, que para todos os materiais os valores de sucção osmótica tornam-se crescentes à medida que o material apresenta-se mais seco. Este comportamento foi semelhante ao observado por Tang et al. (2002), em determinações de sucções osmóticas a partir de ensaios com papel filtro. Adicionalmente, para um mesmo teor de umidade, a sucção osmótica apresenta-se maior para o material 4 seguido dos materiais 3,2,1 e 5, isto ocorre até aproximadamente $300 \mathrm{kPa}$ de sucção, posteriormente os dados experimentais dos materiais com teores de argila mais altos $(2$, 3 e 4) tornam-se relativamente próximos.

Com o objetivo de verificar a influência da concentração dos eletrólitos presentes na água dos poros sobre a sucção osmótica, mediu-se a condutividade elétrica de cada amostra, conforme apresentado no item 5.1.8.

$\mathrm{Na}$ Tabela 45 são mostrados os dados de condutividade elétrica e os valores mínimos e máximos obtidos de sucção osmótica com suas respectivas umidades gravimétricas para cada material e a média dos resultados para o intervalo de dados analisados 
TABELA 45. Intervalos de dados de umidade gravimétrica (\%) e respectivas Sucções Osmóticas $(\mathrm{kPa})$, Sucções Osmóticas médias e Condutividade Elétrica para os cinco materiais

\begin{tabular}{|c|c|c|c|c|c|c|}
\hline Material & $\begin{array}{c}\mathrm{W}_{\text {inicial }} \\
(\%)\end{array}$ & $\begin{array}{c}\mathrm{W}_{\text {final }} \\
(\%)\end{array}$ & $\begin{array}{c}\text { Sucção } \\
\text { Osmótica } \\
(\mathrm{kPa})\end{array}$ & $\begin{array}{c}\text { Sucção } \\
\text { Osmótica } \\
(\mathrm{kPa})\end{array}$ & $\begin{array}{l}\text { Sucção } \\
\text { osmótica } \\
\text { média } \\
(\mathrm{kPa})\end{array}$ & $\begin{array}{c}\text { Condutividade } \\
\text { Elétrica } \\
(\mu \mathrm{S})\end{array}$ \\
\hline 1 & 39,09 & 10,61 & 17,73 & 7180,06 & 727 & 74,3 \\
\hline 2 & 44,90 & 13,91 & 12,25 & 13535,48 & 3250 & 58,7 \\
\hline 3 & 46,80 & 14,20 & 6,34 & 14938,19 & 2939 & 40,1 \\
\hline 4 & 51,11 & 12,44 & 30,78 & 10002,38 & 1822 & 54,0 \\
\hline 5 & 28,45 & 8,36 & 1,83 & 7619,72 & 1498 & 19,3 \\
\hline
\end{tabular}

Foram confrontados os dados de sucção osmótica final e inicial (Tabela 45) com os valores de condutividade elétrica obtidos para cada material (item 5.1.8), buscando observar se havia alguma tendência que mostrasse uma relação entre eles (Figuras $101 \mathrm{e}$ 102).

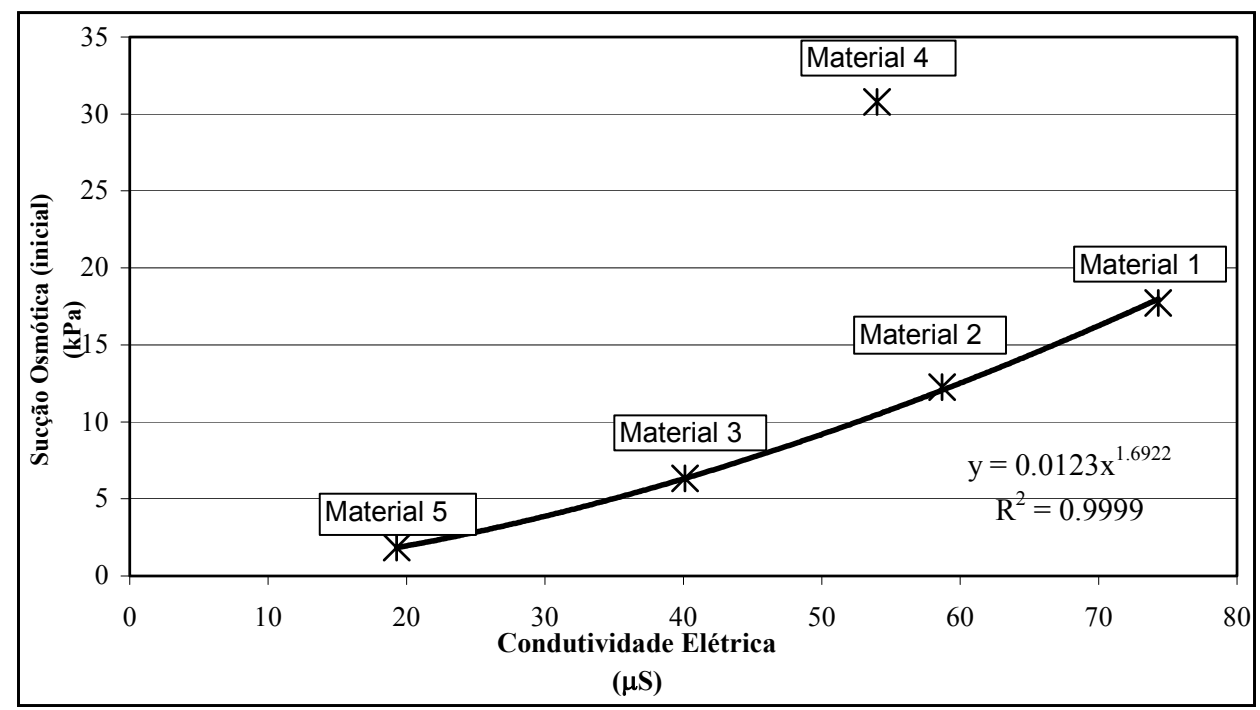

FIGURA 101. Representação dos dados de condutividade elétrica em função dos valores de sucção osmótica inicial para cada material. 


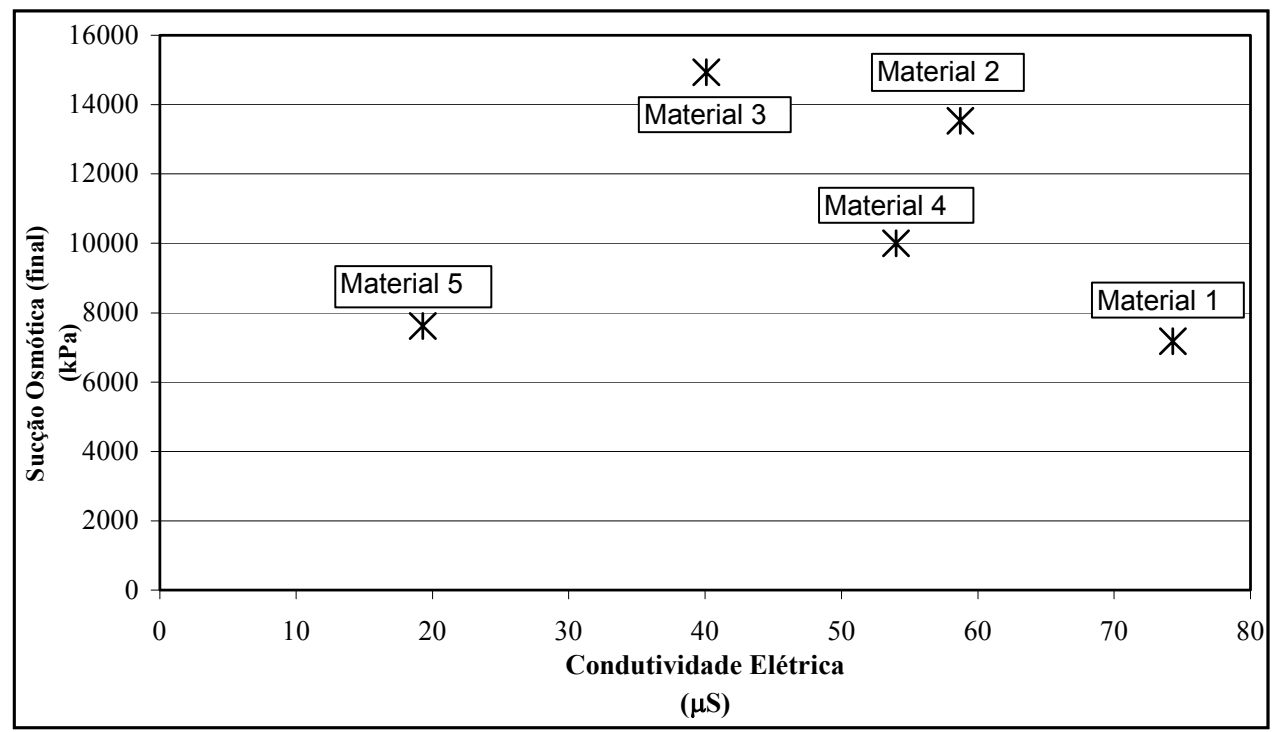

FIGURA 102. Representação dos dados de condutividade elétrica em função dos valores de sucção osmótica final para cada material.

Como mostra a Figura 100, os valores utilizados para a comparação entre os dados de sucção osmótica inicial e final em relação aos dados de condutividade representam para todos os materiais no primeiro caso, valores de umidade gravimétrica próximos a umidade gravimétrica de saturação e no segundo caso, valores onde o material apresenta-se bastante seco. Como pode ser visto na Figura 101, de forma geral, a condutividade elétrica apresenta uma boa correlação com a sucção osmótica quando o material encontra-se com um teor de umidade elevado. Com exceção do material 4, observa-se para os demais materiais, um aumento da sucção osmótica com o aumento da condutividade elétrica. No entanto, quando os materiais apresentam-se mais secos (Figura 102) não se observa o mesmo comportamento. Isto era esperado, pois a variação de umidade afeta também os valores de condutividade elétrica, esta última medida somente para as condições iniciais de cada amostra.

\subsubsection{Análise dos resultados de Sucção Total, Matricial e Osmótica}

Nas Figuras 103, 104 e 105, são mostrados os gráficos de Sucção Matricial, Total e Osmótica versus Umidade Gravimétrica respectivamente. 


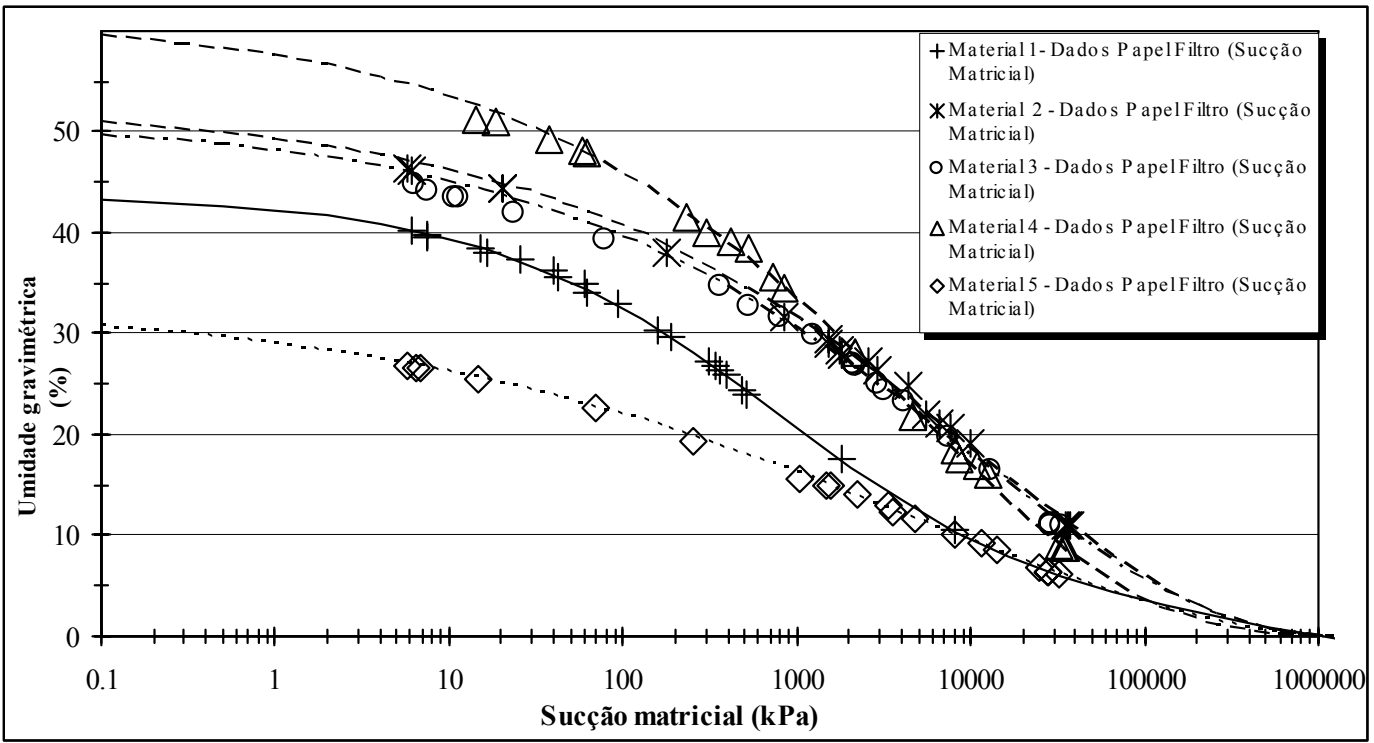

FIGURA 103. Curvas de Retenção obtidas para os cinco materiais pelo método do Papel Filtro (Sucção Matricial).

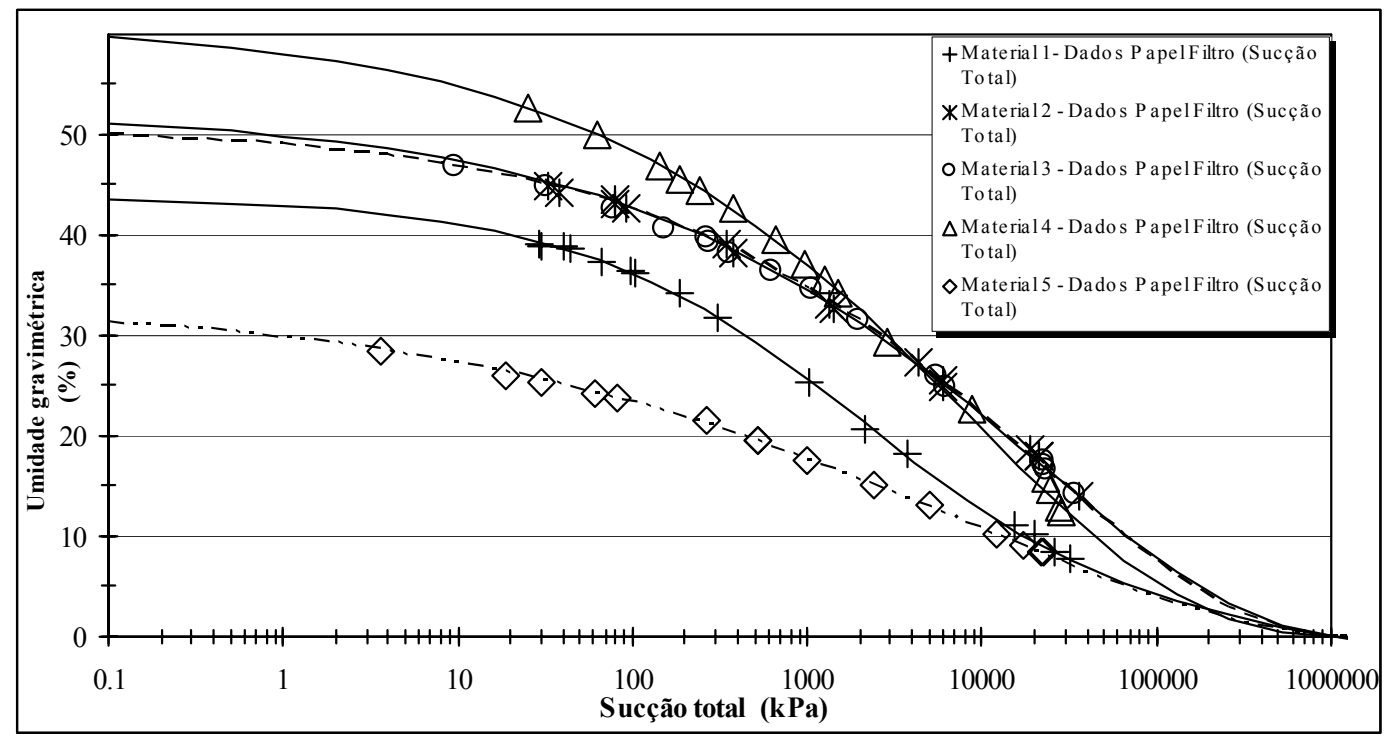

FIGURA 104. Curvas de Retenção obtidas para os cinco materiais pelo método do Papel Filtro (Sucção Total). 


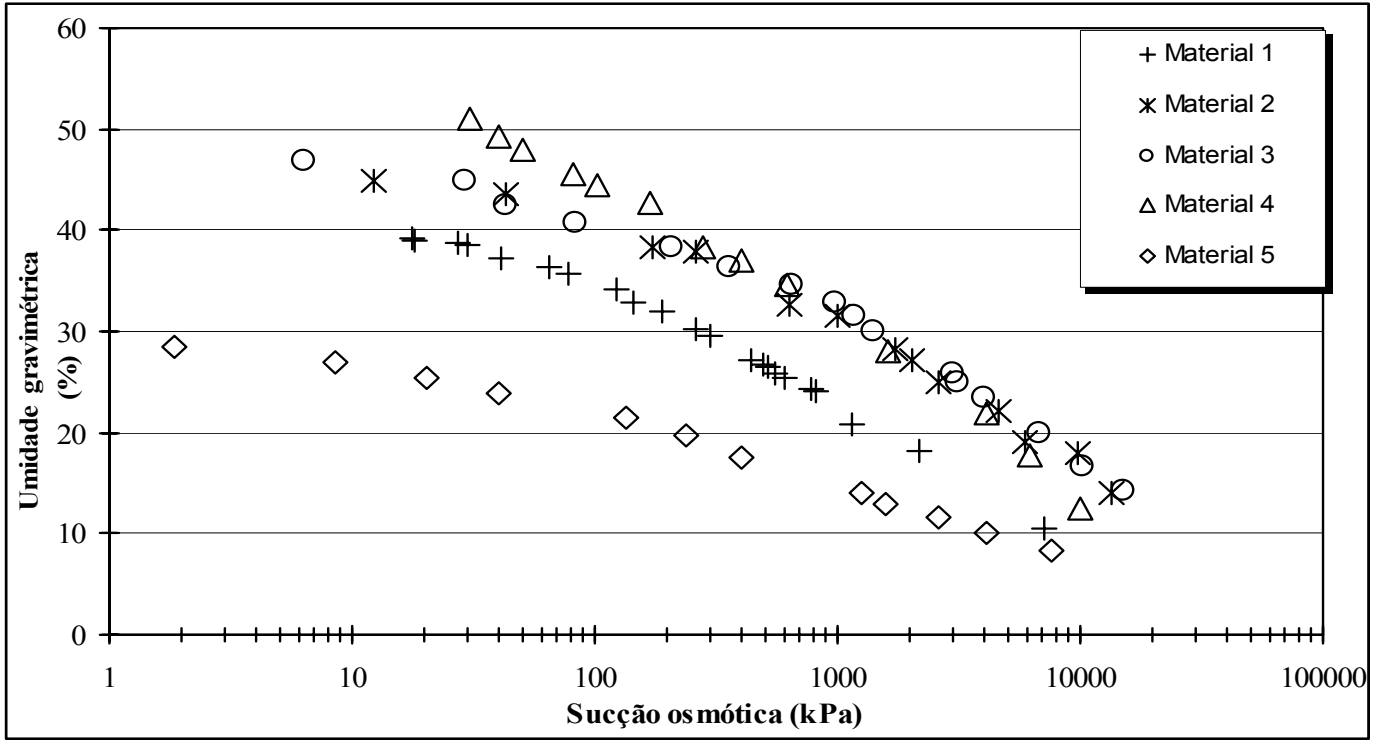

FIGURA 105. Representação dos dados de umidade gravimétrica (\%) e sucção osmótica $(\mathrm{kPa})$ para os cinco materiais.

A partir da Figura 103, verifica-se que os 5 materiais apresentam curvas típicas de materiais argilosos, mostrando grandes variações de sucção matricial com as mudanças de umidade. Destes mesmos gráficos observa-se que para um mesmo valor de sucção o material 4 possui maior retenção, seguido dos materiais 2, 3, 1 e 5, sendo que na maioria dos casos a maior retenção foi proporcional ao teor da fração argila (vide Tabela 08). Finalmente, observa-se que aproximadamente a partir de $1000 \mathrm{kPa}$ de sucção os resultados experimentais dos materiais com maiores teores de argila são muito próximos, fato que, provavelmente pode ser devido à maior e relativa proximidade da porcentagem de meso e microporos observados na Tabela 13.

Os comportamentos observados acima também foram similares aos observados nas curvas de retenção da Figura 104, porém, expressos como sucção total e umidade gravimétrica.

Na Figura 105, observa-se dos resultados de sucção osmótica que os materiais 2, 3 e 4 (em relação aos materiais 1 e 5) apresentam maiores valores de sucção osmótica, sendo muito próximos a partir dos $150 \mathrm{kPa}$ aproximadamente. Em geral, estes resultados mostram, uma maior influência da sucção osmótica para os materiais com maior porcentagem da fração argila (vide Tabela 08). 


\subsubsection{Resultados dos ensaios de curva de retenção pelo método do dessecador de}

vácuo

Os ensaios de curva de retenção para os materiais estudados, foram realizados com a finalidade de servir como referência de comparação em relação ao equilíbrio de sucção obtido nas amostras destinadas aos ensaios de pressão de expansão. Isto devido a que, as amostras para ensaios de pressão de expansão por serem de maior tamanho (7 $\mathrm{cm}$ de diâmetro e $2 \mathrm{~cm}$ de altura) mostraram um tempo de equilíbrio de sucção mais demorado. O maior tempo devido a uma transferência muito lenta de água em forma de vapor em alguns casos, mascara o equilíbrio que é monitorado pelas pesagens sucessivas até constância do peso.

São apresentados na Tabela 46, os resultados experimentais dos ensaios realizados no dessecador de vácuo para a determinação da sucção total e na Figura 106, os gráficos representativos destes dados.

TABELA 46. Resultados de Umidade Gravimétrica (\%) e Sucção Total (kPa), obtidos através do método do dessecador de vácuo

\begin{tabular}{|c|c|c|c|c|c|c|c|}
\hline & & & $\begin{array}{c}\text { Material } \\
1 \\
\end{array}$ & $\begin{array}{c}\text { Material } \\
2 \\
\end{array}$ & $\begin{array}{c}\text { Material } \\
\mathbf{3} \\
\end{array}$ & $\begin{array}{c}\text { Material } \\
4 \\
\end{array}$ & $\begin{array}{c}\text { Material } \\
\mathbf{5} \\
\end{array}$ \\
\hline & \multicolumn{7}{|c|}{ Dados Experimentais } \\
\hline Soluções Salinas & $\begin{array}{c}\mathrm{T}_{\text {equlibrio }} \\
{ }^{0} \mathrm{C} \\
\end{array}$ & $\begin{array}{c}\text { Sucção } \\
\text { Total } \\
(\mathrm{kPa}) \\
\end{array}$ & $\begin{array}{l}\mathrm{W} \\
(\%) \\
\end{array}$ & $\begin{array}{r}\mathrm{W} \\
(\%) \\
\end{array}$ & $\begin{array}{c}\mathrm{W} \\
(\%) \\
\end{array}$ & $\begin{array}{l}\mathrm{W} \\
(\%) \\
\end{array}$ & $\begin{array}{l}\mathrm{W} \\
(\%) \\
\end{array}$ \\
\hline $\mathrm{NaCl}$ saturado & 20,2 & 38851,00 & 8,86 & 15,23 & 15,06 & 11,12 & 8,17 \\
\hline $\mathrm{KCl}$ saturado & 24,2 & 23603,00 & 9,43 & 16,55 & 16,03 & 13,25 & 8,96 \\
\hline $\mathrm{BaCl}_{2} \cdot 2 \mathrm{H}_{2} \mathrm{O}$ saturado & 22,3 & 13869,00 & 10,81 & 18,61 & 18,15 & 14,41 & 9,44 \\
\hline $\mathrm{NaCl}-5 \mathrm{MPa}$ & 23,7 & 4980,34 & 14,99 & 22,95 & 22,47 & 18,31 & 11,98 \\
\hline $\mathrm{NaCl}-3 \mathrm{MPa}$ & 23,3 & 2988,26 & 15,90 & 24,26 & 23,98 & 19,77 & 13,63 \\
\hline $\mathrm{NaCl}-1 \mathrm{MPa}$ & 24,0 & 996,62 & 19,60 & 27,91 & 28,08 & 23,47 & 16,13 \\
\hline
\end{tabular}




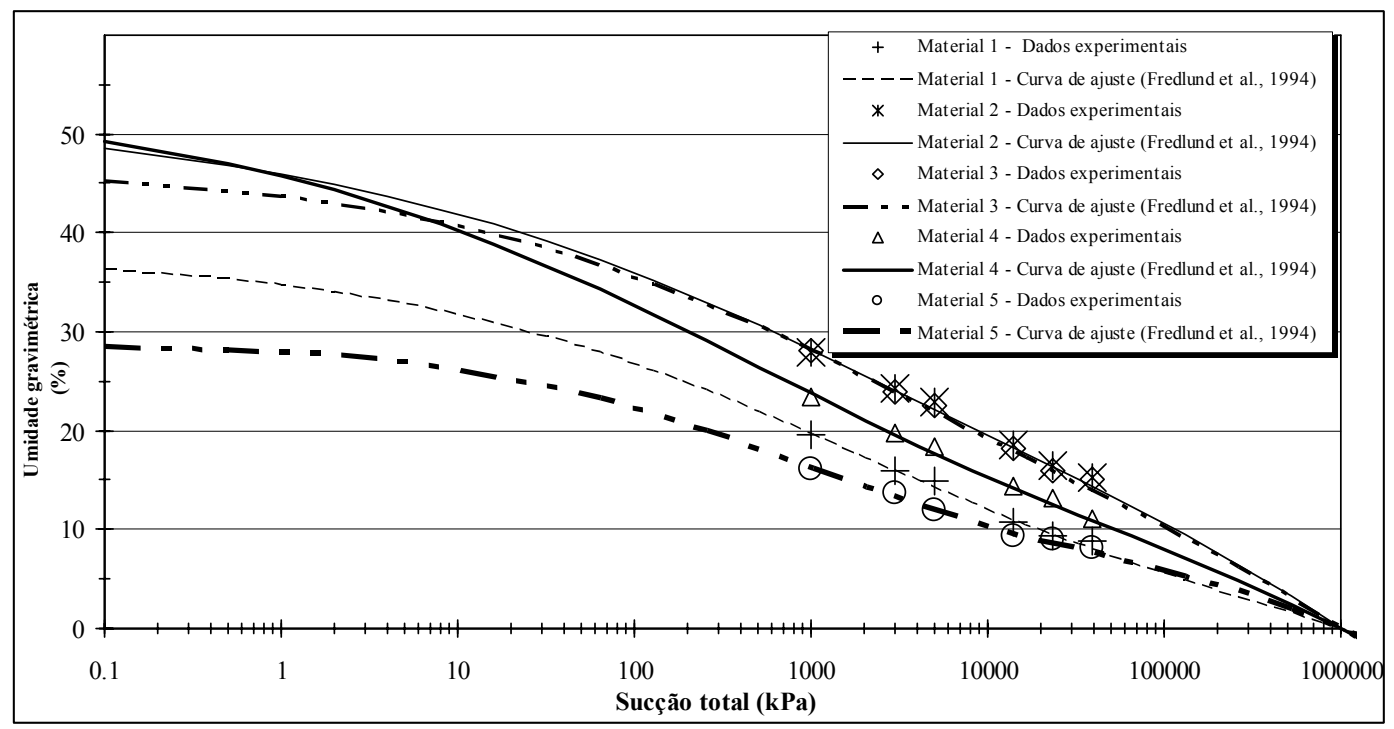

FIGURA 106. Representação das Curvas de retenção geradas a partir do método do dessecador de vácuo.

Os parâmetros de ajuste das Curvas de Retenção para a equação matemática de Fredlund et al. (1994) a partir dos dados experimentais gerados no ensaio do dessecador de vácuo (sucção total) podem ser observados na Tabela 47.

TABELA 47. Parâmetros de ajuste da Curva de Retenção através da equação matemática de Fredlund et al. (1994)

\begin{tabular}{ccccccc}
\hline $\begin{array}{c}\text { PARÂMETROS } \\
\text { Material }\end{array}$ & $\begin{array}{c}\mathrm{w}_{\mathrm{s}} \\
\left(\mathrm{cm}^{3} / \mathrm{cm}^{3}\right)\end{array}$ & $\begin{array}{c}\psi_{\mathrm{r}} \\
(\mathrm{kPa})\end{array}$ & $\mathrm{a}$ & $\mathrm{n}$ & $\mathrm{m}$ & $\mathrm{r}^{2}$ \\
\hline 1 & 0,379 & $10^{6}$ & $2,93 \mathrm{E}+03$ & 0,320 & 3,142 & 0,999 \\
2 & 0,521 & $10^{6}$ & $7,94 \mathrm{E}+03$ & 0,252 & 3,397 & 0,999 \\
3 & 0,468 & $10^{6}$ & $2,83 \mathrm{E}+03$ & 0,318 & 2,411 & 0,999 \\
4 & 0,538 & $10^{6}$ & $6,28 \mathrm{E}+02$ & 0,273 & 2,722 & 0,999 \\
5 & 0,289 & $10^{6}$ & $2,36+\mathrm{E} 02$ & 0,476 & 1,315 & 0,999 \\
\hline
\end{tabular}

\subsubsection{Resultados da calibração dos papéis filtro através das soluções salinas}

A calibração do papel filtro Whatman $\mathrm{n}^{\circ} 42$, segundo procedimento descrito no item 4.2.2.4, foi realizada nesta pesquisa, com o intuito de verificar se a calibração para o mesmo papel determinada por Chandler et al. (1992), eram condizentes com os obtidos neste estudo (faixa de 1000 a $40000 \mathrm{kPa}$ ), quando se trata dos materiais argilosos da Formação Guabirotuba analisados. 
São apresentados na Tabela 48, os resultados dos ensaios realizados através de soluções salinas no dessecador de vácuo para a calibração dos papéis filtro Whatman $\mathrm{n}^{\circ} 42$. Complementarmente a este procedimento, também foram colocados papéis filtro junto às amostras cuja imposição de sucção era destinada aos ensaios edométricos convencionais e junto com as amostras para a geração da curva de retenção, a fim de que atingissem o equilíbrio para cada sucção imposta, sendo os resultados representados na Tabela 48 .

TABELA 48. Dados experimentais obtidos para a calibração do papel filtro Whatman $\mathrm{n}^{\circ} 42$

\begin{tabular}{|c|c|c|c|c|c|c|}
\hline \multicolumn{7}{|c|}{ CALIBRAÇÃO DO PAPEL FILTRO } \\
\hline & \multicolumn{2}{|c|}{ Dessecador de vácuo } & \multicolumn{2}{|c|}{$\begin{array}{c}\text { Equilíbrio junto com } \\
\text { amostras para Curva de } \\
\text { Retenção } \\
\end{array}$} & \multicolumn{2}{|c|}{$\begin{array}{c}\text { Equilíbrio junto com } \\
\text { amostras para ensaios } \\
\text { edométricos convencionais }\end{array}$} \\
\hline \multicolumn{7}{|c|}{ DADOS EXPERIMENTAIS } \\
\hline Soluções Salinas & $\mathrm{w} \%$ & $\begin{array}{c}\text { Sucção Total } \\
(\mathrm{kPa})\end{array}$ & $\mathrm{w} \%$ & $\begin{array}{c}\text { Sucção Total } \\
(\mathrm{kPa})\end{array}$ & $\mathrm{w} \%$ & $\begin{array}{c}\text { Sucção Total } \\
(\mathrm{kPa})\end{array}$ \\
\hline $\mathrm{NaCl}$ saturado & 8,27 & 39627,00 & 8,06 & 39872,00 & 8,02 & 39668,00 \\
\hline $\mathrm{KCl}$ saturado & 10,95 & 23538,00 & 10,03 & 23764,00 & 10,32 & 23538,00 \\
\hline $\mathrm{BaCl}_{2} \cdot 2 \mathrm{H}_{2} \mathrm{O}$ saturado & 12,98 & 14495,00 & 12,89 & 14495,00 & 12,18 & 14864,00 \\
\hline $\mathrm{NaCl}-5 \mathrm{MPa}$ & 20,72 & 4980,11 & 18,80 & 5014,54 & 19,49 & 4982,63 \\
\hline $\mathrm{NaCl}-3 \mathrm{MPa}$ & 22,87 & 2988,94 & 22,33 & 2988,99 & 23,52 & 2988,51 \\
\hline $\mathrm{NaCl}-1 \mathrm{MPa}$ & 28,50 & 996,62 & 28,25 & 996,62 & 28,48 & 996,63 \\
\hline
\end{tabular}

Na Figura 107 são mostrados os resultados da Tabela 48, os quais foram plotados em conjunto, com a finalidade de se obter uma equação (28) representativa dos mesmos, que relacionasse a umidade do papel Whatman $n^{0} 42$ e sucção total. Isto foi realizado para ser comparado com a calibração do mesmo papel, porém, proveniente de Chandler et al. (1992), mostradas nas equações 22 e 23. Cabe relembrar que a calibração foi feita para uma faixa de sucção total entre 1000 e $40000 \mathrm{kPa}$, em função das sucções que forneceram as soluções salinas utilizadas neste estudo. 


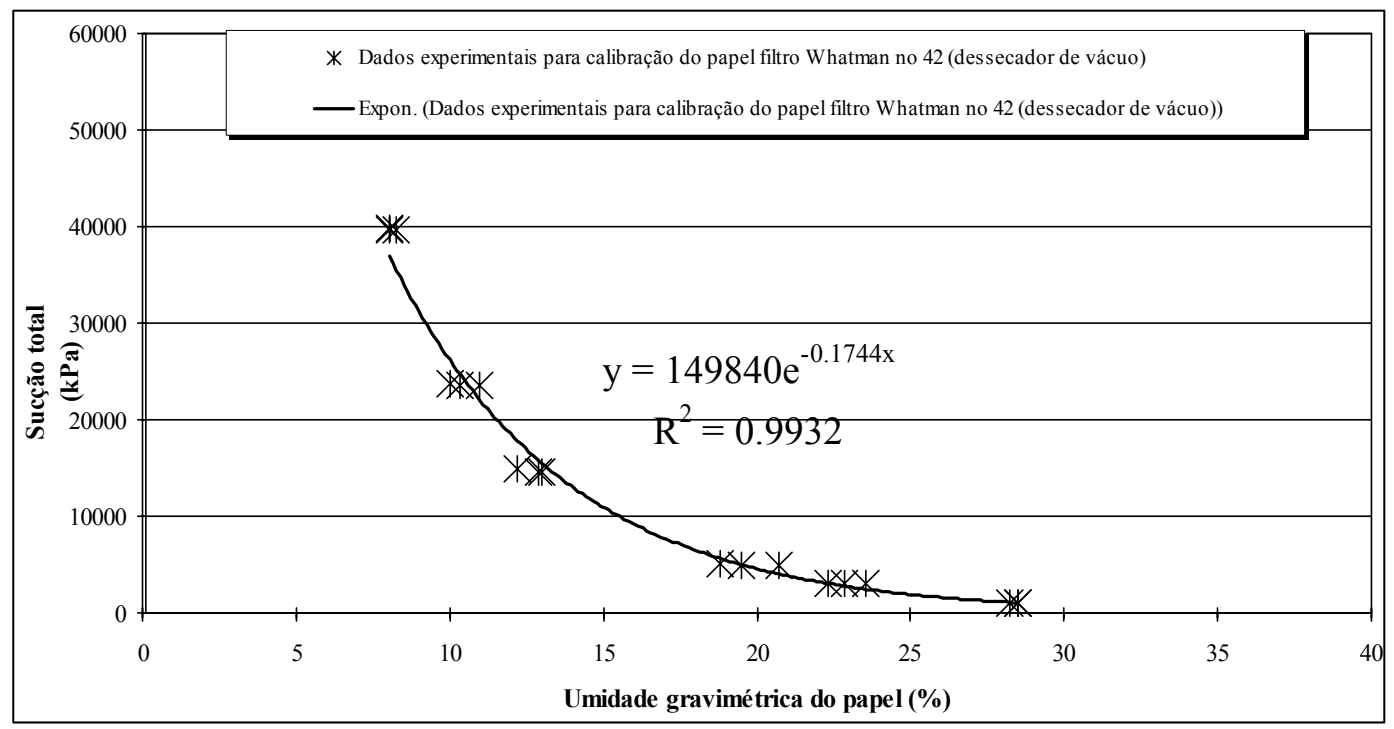

FIGURA 107. Representação conjunta dos dados experimentais gerados para a calibração do papel filtro Whatman $n^{\circ} 42$.

$\psi_{\mathrm{t}}=149840 \mathrm{e}^{-0,1744 \mathrm{w}}$

Onde:

$\psi_{\mathrm{t}}=$ sucção total $(\mathrm{kPa})$ e $\mathrm{w}=$ umidade gravimétrica do papel filtro $(\%)$, obtida no ensaio de papel filtro para a determinação da sucção total.

\subsubsection{Técnicas do Dessecador de vácuo e do Papel Filtro}

Nas Figuras 108 a 112 encontram-se os resultados das curvas de retenção obtidos pelo processo de secagem com auxílio dos métodos de papel filtro e por umedecimento pelo método do dessecador de vácuo. Para os resultados dos ensaios de papel filtro a sucção total foi calculada, empregando-se as curvas de calibração de Chandler et al. (1992) (equações 22 e 23) e a obtida neste trabalho (equação 28). Já os resultados dos ensaios do dessecador de vácuo, são incluídos para comparar as curvas de retenção entre ambos os processos (umedecimento e secagem). 


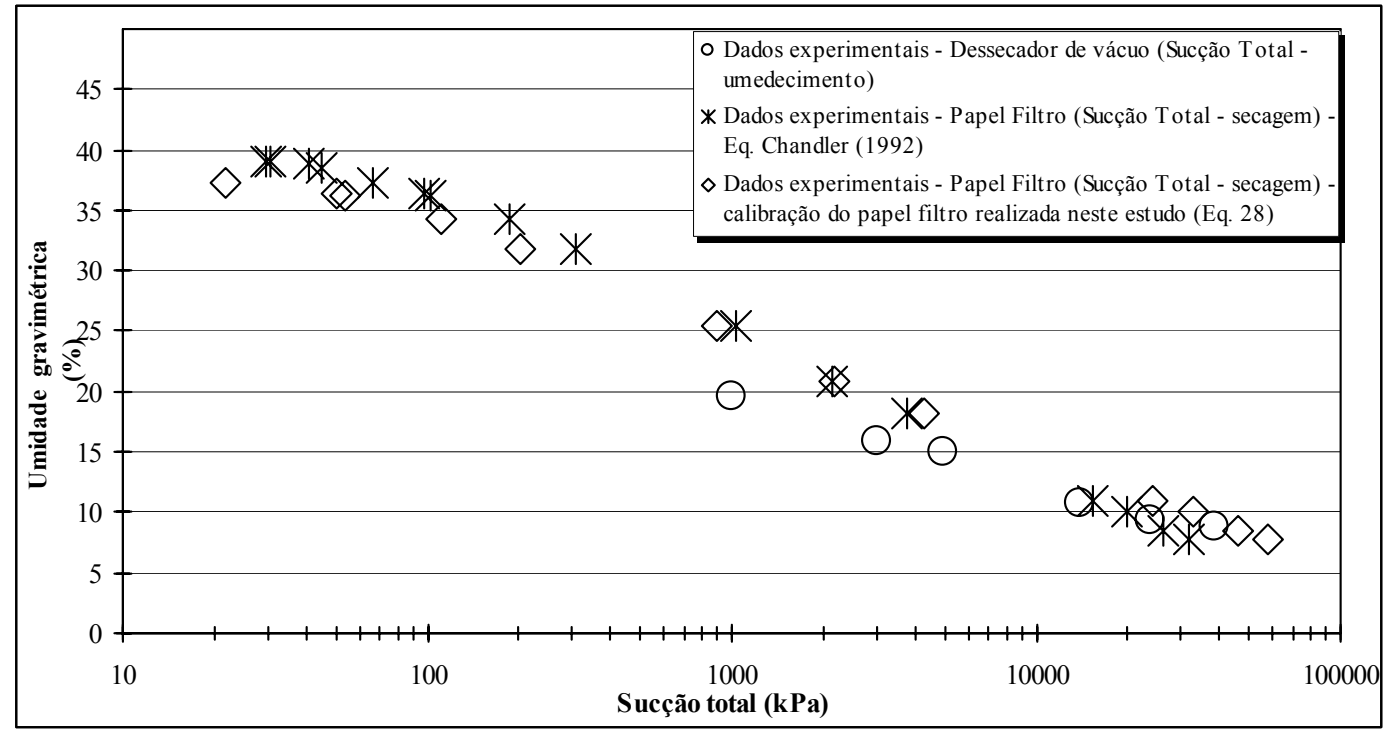

FIGURA 108. Análise dos dados experimentais (umidade gravimétrica (\%) e sucção total $(\mathrm{kPa})$ ) obtidos para o Material 1 (papel filtro).

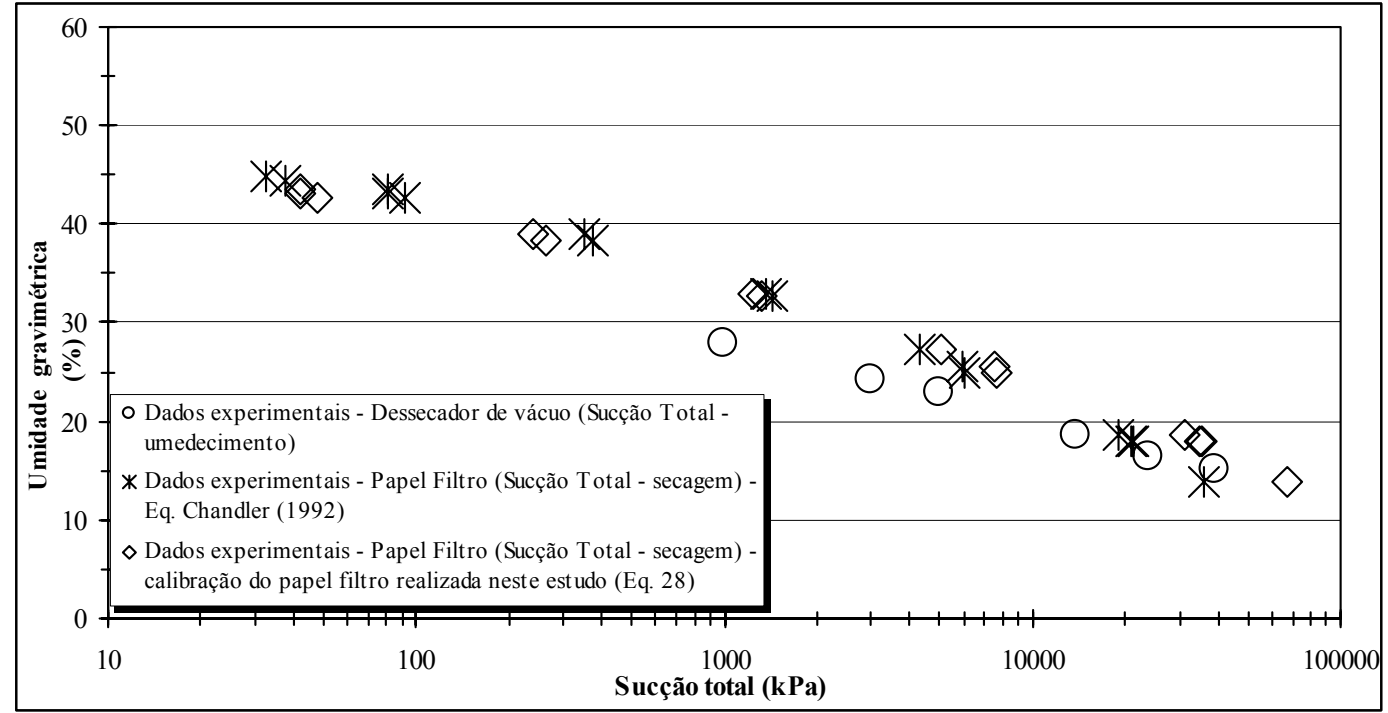

FIGURA 109. Análise dos dados experimentais (umidade gravimétrica (\%) e sucção total $(\mathrm{kPa})$ ) obtidos para o Material 2 (papel filtro). 


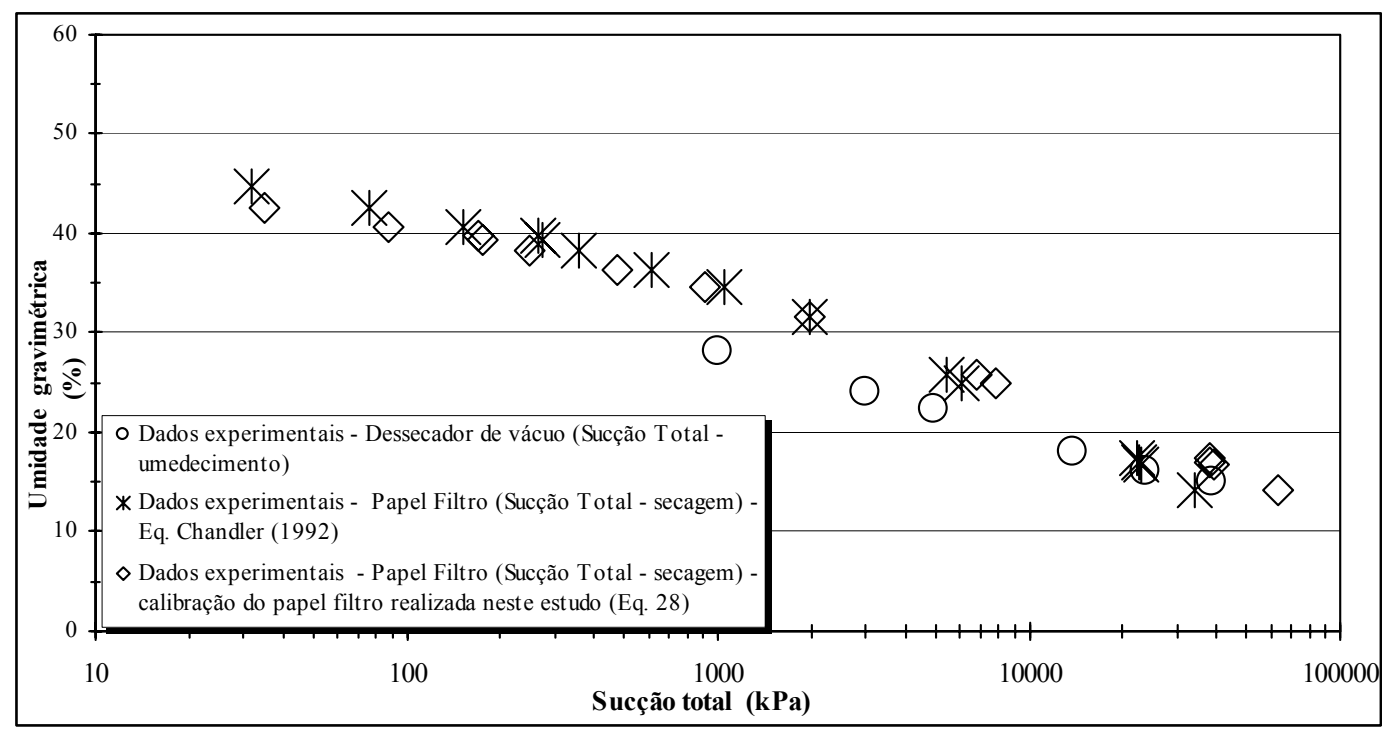

FIGURA 110. Análise dos dados experimentais (umidade gravimétrica (\%) e sucção total $(\mathrm{kPa})$ ) obtidos para o Material 3 (papel filtro).

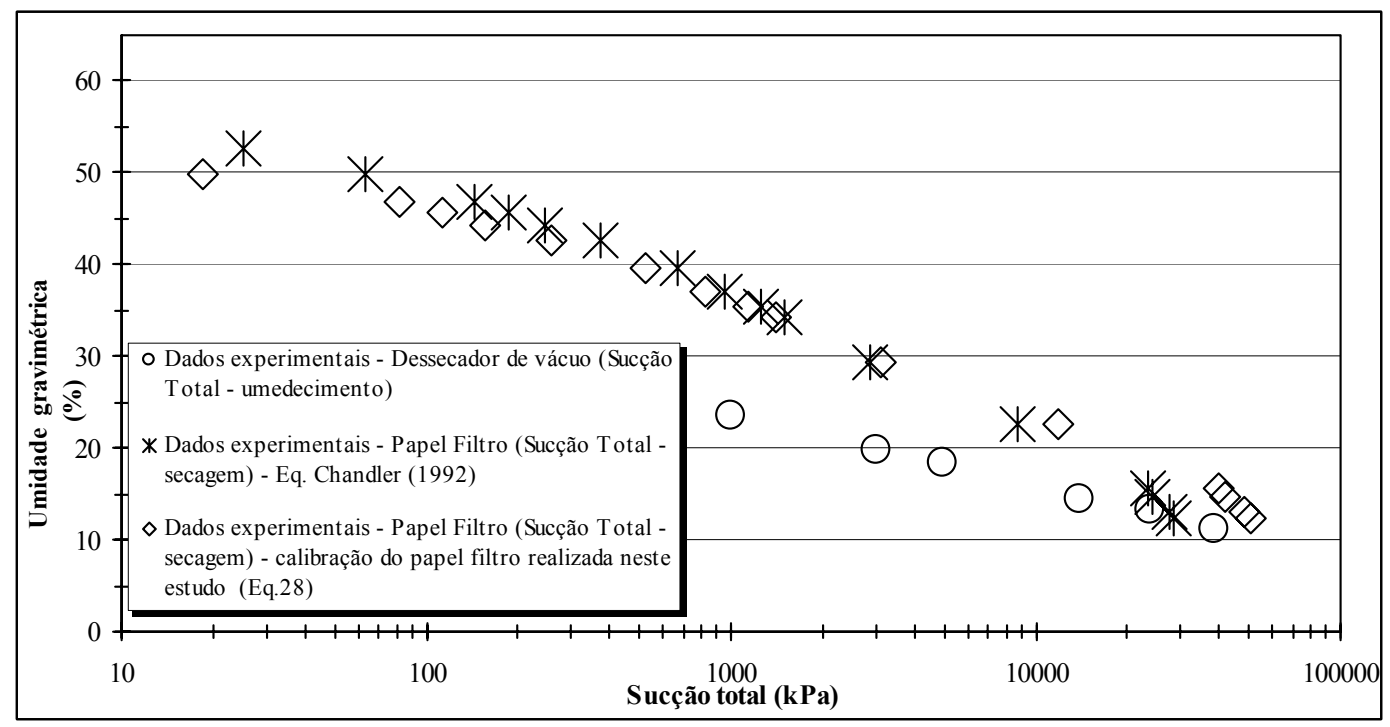

FIGURA 111. Análise dos dados experimentais (umidade gravimétrica (\%) e sucção total $(\mathrm{kPa})$ ) obtidos para o Material 4 (papel filtro). 


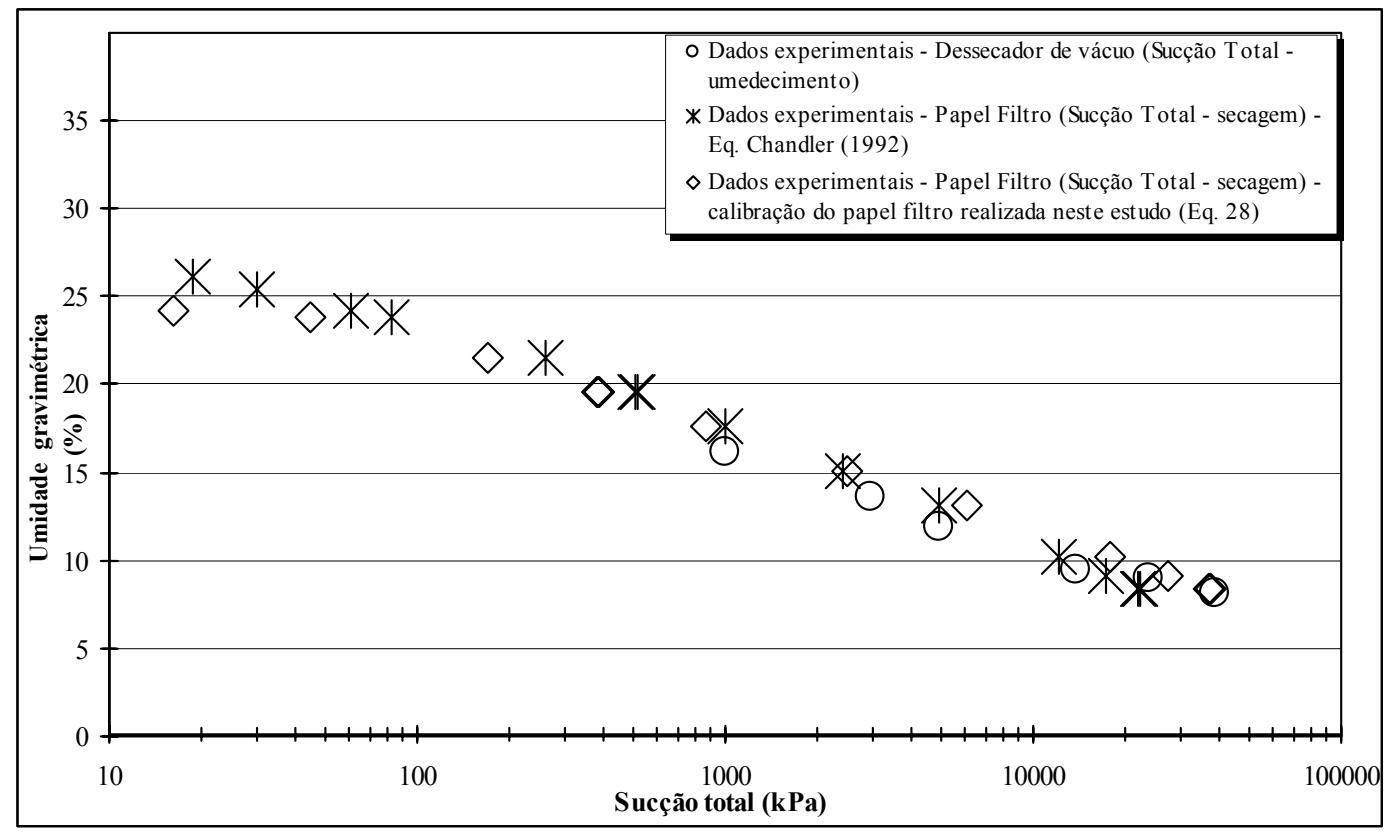

FIGURA 112. Análise dos dados experimentais (umidade gravimétrica (\%) e sucção total $(\mathrm{kPa})$ ) obtidos para o Material 5 (papel filtro).

Quanto aos resultados experimentais obtidos através do ensaio de papel filtro, gerados a partir das duas calibrações para o mesmo tipo de papel (Whatman $n^{\circ} 42$ ), pode-se dizer que, dentro da faixa de sucção observada, entre 1.000 e $40.000 \mathrm{kPa}$, os dados de sucção total obtidos a partir da calibração de Chandler et al. (1992), foram na maioria inferiores aos obtidos pela calibração realizada neste estudo, acentuando-se a diferença de valores com o aumento da sucção total. Esta diferença ocorre aproximadamente a partir de uma umidade do papel inferior a $13 \%$ ou sucções superiores aos $1.000 \mathrm{kPa}$. Outros autores apresentam diferenças semelhantes como pode ser visto na Figura 113, onde têm-se uma recompilação da calibração de diversos pesquisadores fornecida por Marinho (1995). 


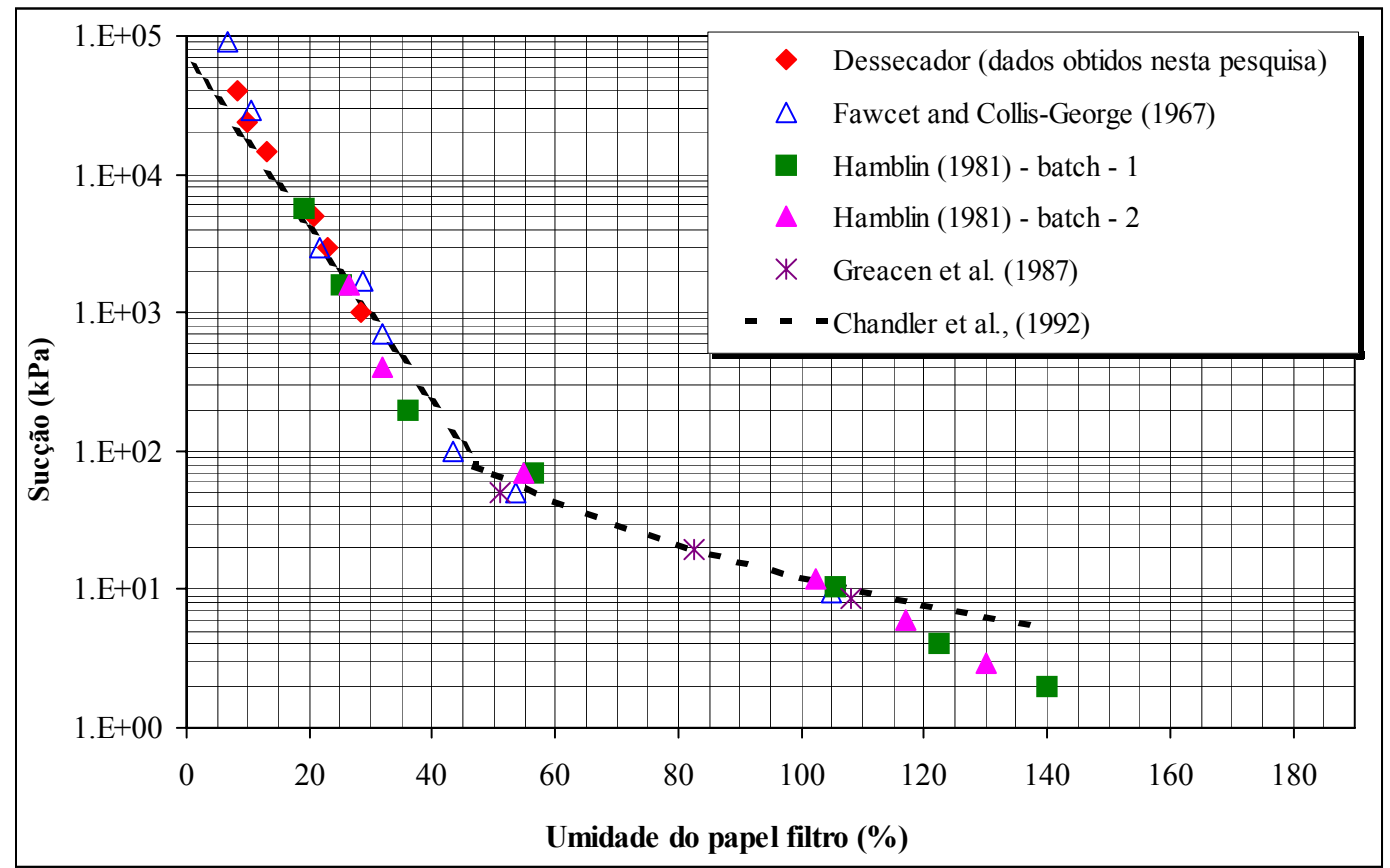

FIGURA 113. Dados experimentais obtidos neste estudo e de diversos autores (Marinho, 1995) da calibração do papel filtro Whatman $n^{\circ} 42$, bem como, a curva de ajuste a partir de Chandler et al. (1992).

Neste gráfico também foram incluídos os resultados obtidos neste estudo, além da curva de calibração de Chandler et al. (1992), determinada a partir das equações 22 e 23. Como pode-se observar, os dados provenientes da calibração pelo dessecador se situam entre os determinados por outros autores.

Quando comparados os resultados das curvas de retenção pelos processos de umedecimento e secagem, se observa, como esperado, diferenças entre umidades para um mesmo valor de sucção. O maior teor de umidade para uma determinada sucção ocorre para o processo de secagem, isto é devido provavelmente ao fenômeno de histerese, que é mais acentuado nos materiais argilo-siltosos (materiais 1 ao 4) do que no material areno-silto-argiloso (material 5). 


\subsection{Ensaios de Expansão}

\subsubsection{Ensaios edométricos convencionais}

Os índices físicos das amostras ensaiadas estão representados na Tabela 49. Na Tabela 50 estão representados todos os resultados obtidos para as amostras submetidas aos ensaios de pressão de expansão com umidades iniciais natural, secas ao ar e com imposição de sucção. Pode-se observar que as amostras com umidade natural apresentaram uma pressão de expansão nula ou praticamente nula, provavelmente por possuírem graus de saturação bastante elevados. Os valores de pressão de expansão das amostras com umidade natural variaram num intervalo entre $0 \mathrm{kPa}$ a $11,1 \mathrm{kPa}$ e para as amostras secas ao ar, num intervalo entre $458 \mathrm{kPa}$ e $4639 \mathrm{kPa}$. Cabe ressaltar, que os valores para a pressão de expansão estão intimamente ligados aos teores de umidade nas quais as amostras foram ensaiadas, e podem variar caso sejam modificados estes teores.

São mostradas nas Tabelas 51, 52 e 53, os valores de sucção total que foram impostos às amostras em função da temperatura e umidade relativa. Na Figura 114, estão representados os dados de sucção total e temperatura (Tabelas 51, 52 e 53), com as respectivas equações, que permitiram a correção da sucção total, devido às variações de temperatura, quando utilizadas as soluções salinas saturadas. Para as soluções salinas de $\mathrm{NaCl}$ em diferentes concentrações, o mesmo procedimento foi realizado, no entanto, utilizando a calibração de Lang (1967)

Os resultados de pressão de expansão para as amostras secas ao ar e também para aquelas submetidas à imposição de sucção para cada material foram plotados conjuntamente em gráficos de Pressão de Expansão (kPa) e Tempo (h) (Figuras 115, 116, 117, 118 e 119). Devido às amostras com umidade natural apresentarem uma pressão de expansão muito baixa, os resultados não foram plotados em gráficos. 
TABELA 49. Índices físicos das amostras ensaiadas

\begin{tabular}{|c|c|c|c|c|c|c|c|c|}
\hline Material & Descrição & $\begin{array}{c}\mathrm{W}_{\text {equilibrio }} \\
(\%)\end{array}$ & $\begin{array}{c}\rho_{\mathrm{s}} \\
\left(\mathrm{g} / \mathrm{cm}^{3}\right)\end{array}$ & $\begin{array}{c}\rho \\
\left(\mathrm{g} / \mathrm{cm}^{3}\right)\end{array}$ & $\begin{array}{c}\rho_{\mathrm{d}} \\
\left(\mathrm{g} / \mathrm{cm}^{3}\right)\end{array}$ & $\mathrm{e}$ & $\begin{array}{c}n \\
(\%) \\
\end{array}$ & $\begin{array}{c}\mathrm{Sr} \\
(\%) \\
\end{array}$ \\
\hline \multirow[t]{8}{*}{1} & Amostra seca ao ar & 7,5 & 2,682 & 1,713 & 1,593 & 0,684 & 40,6 & 29,6 \\
\hline & Amostra com umidade natural & 36,0 & 2,682 & 1,717 & 1,263 & 1,124 & 52,9 & 85,9 \\
\hline & Sucção imposta por $\mathrm{NaCl}$ saturado & 8,8 & 2,682 & 1,810 & 1,663 & 0,612 & 38,0 & 38,6 \\
\hline & Sucção imposta por $\mathrm{KCl}$ saturado & 9,6 & 2,682 & 1,824 & 1,665 & 0,611 & 37,9 & 42,0 \\
\hline & Sucção imposta por $\mathrm{BaCl}_{2} \cdot 2 \mathrm{H}_{2} \mathrm{O}$ saturado & 11,5 & 2,682 & 1,857 & 1,666 & 0,610 & 37,9 & 50,5 \\
\hline & Sucção imposta por $\mathrm{NaCl}-5000 \mathrm{kPa}$ & 15,5 & 2,682 & 1,933 & 1,674 & 0,602 & 37,6 & 69,0 \\
\hline & Sucção imposta por $\mathrm{NaCl}-3000 \mathrm{kPa}$ & 16,0 & 2,682 & 1,935 & 1,669 & 0,607 & 37,8 & 70,5 \\
\hline & Sucção imposta por $\mathrm{NaCl}-1000 \mathrm{kPa}$ & 20,0 & 2,682 & 1,925 & 1,604 & 0,672 & 40,2 & 79,9 \\
\hline \multirow[t]{8}{*}{2} & Amostra seca ao ar & 12,7 & 2,676 & 2,072 & 1,838 & 0,455 & 31,3 & 74,4 \\
\hline & Amostra com umidade natural & 41,4 & 2,676 & 1,751 & 1,238 & 1,161 & 53,7 & 95,4 \\
\hline & Sucção imposta por $\mathrm{NaCl}$ saturado & 14,9 & 2,676 & 2,015 & 1,753 & 0,526 & 34,5 & 75,9 \\
\hline & Sucção imposta por $\mathrm{KCl}$ saturado & 16,6 & 2,676 & 2,057 & 1,763 & 0,518 & 34,1 & 86,0 \\
\hline & Sucção imposta por $\mathrm{BaCl}_{2} \cdot 2 \mathrm{H}_{2} \mathrm{O}$ saturado & 18,1 & 2,676 & 2,052 & 1,738 & 0,540 & 35,1 & 89,7 \\
\hline & Sucção imposta por $\mathrm{NaCl}-5000 \mathrm{kPa}$ & 22,0 & 2,676 & 1,991 & 1,632 & 0,640 & 39,0 & 91,9 \\
\hline & Sucção imposta por $\mathrm{NaCl}-3000 \mathrm{kPa}$ & 23,3 & 2,676 & 1,967 & 1,595 & 0,677 & 40,4 & 92,0 \\
\hline & Sucção imposta por $\mathrm{NaCl}-1000 \mathrm{kPa}$ & 28,2 & 2,676 & 1,894 & 1,478 & 0,811 & 44,8 & 92,9 \\
\hline \multirow[t]{8}{*}{3} & Amostra seca ao ar & 12,4 & 2,699 & 1,977 & 1,759 & 0,535 & 34,8 & 62,6 \\
\hline & Amostra com umidade natural & 36,9 & 2,699 & 1,749 & 1,278 & 1,112 & 52,7 & 89,5 \\
\hline & Sucção imposta por $\mathrm{NaCl}$ saturado & 14,7 & 2,699 & 1,931 & 1,683 & 0,604 & 37,6 & 65,8 \\
\hline & Sucção imposta por $\mathrm{KCl}$ saturado & 16,7 & 2,699 & 1,974 & 1,692 & 0,595 & 37,3 & 75,6 \\
\hline & Sucção imposta por $\mathrm{BaCl}_{2} \cdot 2 \mathrm{H}_{2} \mathrm{O}$ saturado & 17,8 & 2,699 & 1,982 & 1,682 & 0,605 & 37,7 & 79,7 \\
\hline & Sucção imposta por $\mathrm{NaCl}-5000 \mathrm{kPa}$ & 22,5 & 2,699 & 1,937 & 1,582 & 0,706 & 41,4 & 85,9 \\
\hline & Sucção imposta por $\mathrm{NaCl}-3000 \mathrm{kPa}$ & 23,9 & 2,699 & 1,911 & 1,543 & 0,749 & 42,8 & 86,0 \\
\hline & Sucção imposta por $\mathrm{NaCl}-1000 \mathrm{kPa}$ & 28,7 & 2,699 & 1,848 & 1,436 & 0,879 & 46,8 & 88,0 \\
\hline \multirow[t]{8}{*}{4} & Amostra seca ao ar & 8,2 & 2,674 & 1,730 & 1,600 & 0,671 & 40,2 & 32,3 \\
\hline & Amostra com umidade natural & 51,0 & 2,674 & 1,657 & 1,097 & 1,437 & 53,8 & 94,9 \\
\hline & Sucção imposta por $\mathrm{NaCl}$ saturado & 10,6 & 2,674 & 1,813 & 1,639 & 0,632 & 38,7 & 45,0 \\
\hline & Sucção imposta por $\mathrm{KCl}$ saturado & 13,0 & 2,674 & 1,840 & 1,628 & 0,643 & 39,1 & 54,3 \\
\hline & Sucção imposta por $\mathrm{BaCl}_{2} \cdot 2 \mathrm{H}_{2} \mathrm{O}$ saturado & 14,2 & 2,674 & 1,941 & 1,700 & 0,573 & 36,4 & 66,2 \\
\hline & Sucção imposta por $\mathrm{NaCl}-5000 \mathrm{kPa}$ & 17,7 & 2,674 & 1,990 & 1,690 & 0,582 & 36,8 & 81,4 \\
\hline & Sucção imposta por $\mathrm{NaCl}-3000 \mathrm{kPa}$ & 19,9 & 2,674 & 1,969 & 1,657 & 0,614 & 38,1 & 82,1 \\
\hline & Sucção imposta por $\mathrm{NaCl}-1000 \mathrm{kPa}$ & 23,7 & 2,674 & 1,896 & 1,533 & 0,744 & 42,7 & 85,0 \\
\hline \multirow[t]{8}{*}{5} & Amostra seca ao ar & 8,1 & 2,653 & 1,801 & 1,665 & 0,593 & 37,2 & 36,4 \\
\hline & Amostra com umidade natural & 24,4 & 2,653 & 1,870 & 1,504 & 0,764 & 43,3 & 84,7 \\
\hline & Sucção imposta por $\mathrm{NaCl}$ saturado & 7,6 & 2,653 & 1,820 & 1,692 & 0,568 & 36,2 & 35,3 \\
\hline & Sucção imposta por $\mathrm{KCl}$ saturado & 9,0 & 2,653 & 1,769 & 1,622 & 0,635 & 38,8 & 37,6 \\
\hline & Sucção imposta por $\mathrm{BaCl}_{2} \cdot 2 \mathrm{H}_{2} \mathrm{O}$ saturado & 9,7 & 2,653 & 1,872 & 1,706 & 0,555 & 35,7 & 46,5 \\
\hline & Sucção imposta por $\mathrm{NaCl}-5000 \mathrm{kPa}$ & 12,3 & 2,653 & 1,829 & 1,629 & 0,629 & 38,6 & 51,9 \\
\hline & Sucção imposta por $\mathrm{NaCl}-3000 \mathrm{kPa}$ & 13,0 & 2,653 & 1,816 & 1,607 & 0,651 & 39,4 & 53,1 \\
\hline & Sucção imposta por $\mathrm{NaCl}-1000 \mathrm{kPa}$ & 17,1 & 2,653 & 1,834 & 1,566 & 0,694 & 41,0 & 65,4 \\
\hline
\end{tabular}


TABELA 50. Resultados obtidos para o ensaio de Pressão de Expansão no Edômetro convencional para as amostras dos cinco materiais

\begin{tabular}{|c|c|c|c|c|c|}
\hline Material & Descrição & $\begin{array}{c}\mathrm{W}_{\text {equilíbrio }} \\
(\%) \\
\end{array}$ & $\begin{array}{c}\mathrm{T}_{\text {equilibrio }} \\
\left({ }^{0} \mathrm{C}\right) \\
\end{array}$ & $\begin{array}{l}\text { Sucção Total } \\
(\mathrm{MPa}) \\
\end{array}$ & $\begin{array}{c}\text { Pressão de Expansão } \\
(\mathrm{kPa})\end{array}$ \\
\hline \multirow[t]{8}{*}{1} & Amostra seca ao ar & 7,5 & - & $46^{*}$ & 457,85 \\
\hline & Amostra com umidade natural & 36,0 & - & $0,0002 *$ & 0 \\
\hline & Sucção imposta por $\mathrm{NaCl}$ saturado & 8,8 & 24 & 40 & 418,43 \\
\hline & Sucção imposta por $\mathrm{KCl}$ saturado & 9,6 & 24 & 24 & 274,21 \\
\hline & Sucção imposta por $\mathrm{BaCl}_{2} \cdot 2 \mathrm{H}_{2} \mathrm{O}$ saturado & 11,5 & 25 & 15 & 193,08 \\
\hline & Sucção imposta por $\mathrm{NaCl}-5000 \mathrm{kPa}$ & 15,5 & 24 & 5 & 140,39 \\
\hline & Sucção imposta por $\mathrm{NaCl}-3000 \mathrm{kPa}$ & 16,0 & 23,2 & 3 & 84,99 \\
\hline & Sucção imposta por $\mathrm{NaCl}-1000 \mathrm{kPa}$ & 20,0 & 23,2 & 1 & 35,33 \\
\hline \multirow[t]{8}{*}{2} & Amostra seca ao ar & 12,7 & - & $60 *$ & 4639,08 \\
\hline & Amostra com umidade natural & 41,4 & - & $0,01 *$ & 0 \\
\hline & Sucção imposta por $\mathrm{NaCl}$ saturado & 14,9 & 24 & 40 & 4189,33 \\
\hline & Sucção imposta por $\mathrm{KCl}$ saturado & 16,6 & 24 & 24 & 2968,9 \\
\hline & Sucção imposta por $\mathrm{BaCl}_{2} \cdot 2 \mathrm{H}_{2} \mathrm{O}$ saturado & 18,1 & 25 & 15 & 1465,19 \\
\hline & Sucção imposta por $\mathrm{NaCl}-5000 \mathrm{kPa}$ & 22,0 & 24 & 5 & 729,4 \\
\hline & Sucção imposta por $\mathrm{NaCl}-3000 \mathrm{kPa}$ & 23,3 & 23,2 & 3 & 599,75 \\
\hline & Sucção imposta por $\mathrm{NaCl}-1000 \mathrm{kPa}$ & 28,2 & 23,2 & 1 & 181,63 \\
\hline \multirow[t]{8}{*}{3} & Amostra seca ao ar & 12,4 & - & $58 *$ & 2949,82 \\
\hline & Amostra com umidade natural & 36,9 & - & $0,06^{*}$ & 11,11 \\
\hline & Sucção imposta por $\mathrm{NaCl}$ saturado & 14,7 & 24 & 40 & 2076,58 \\
\hline & Sucção imposta por $\mathrm{KCl}$ saturado & 16,7 & 24 & 24 & 1670,75 \\
\hline & Sucção imposta por $\mathrm{BaCl}_{2} \cdot 2 \mathrm{H}_{2} \mathrm{O}$ saturado & 17,9 & 25 & 15 & 978,82 \\
\hline & Sucção imposta por $\mathrm{NaCl}-5000 \mathrm{kPa}$ & 22,5 & 24 & 5 & 696,8 \\
\hline & Sucção imposta por $\mathrm{NaCl}-3000 \mathrm{kPa}$ & 23,9 & 23,2 & 3 & 555,65 \\
\hline & Sucção imposta por $\mathrm{NaCl}-1000 \mathrm{kPa}$ & 28,7 & 23,2 & 1 & 170,18 \\
\hline \multirow[t]{9}{*}{4} & Amostra seca ao ar & 8,1 & - & $98 *$ & 3004,44 \\
\hline & Amostra com umidade natural & 51,0 & - & $0,0001 *$ & 4,24 \\
\hline & Sucção imposta por $\mathrm{NaCl}$ saturado & 10,6 & 24 & 40 & 1889,9 \\
\hline & Sucção imposta por $\mathrm{KCl}$ saturado & 13,0 & 24 & 24 & 1158,45 \\
\hline & Sucção imposta por $\mathrm{BaCl}_{2} \cdot 2 \mathrm{H}_{2} \mathrm{O}$ saturado & 14,2 & 25 & 15 & 913,91 \\
\hline & Sucção imposta por $\mathrm{NaCl}-5000 \mathrm{kPa}$ & 17,7 & 24 & 5 & 658,09 \\
\hline & Sucção imposta por $\mathrm{NaCl}-3000 \mathrm{kPa}$ & 18,9 & 23,2 & 3 & 256,98 \\
\hline & Sucção imposta por $\mathrm{NaCl}-1000 \mathrm{kPa}$ & 23,7 & 23,2 & 1 & 106,16 \\
\hline & Translação de eixos $(900 \mathrm{kPa})$ & 34,7 & - & 0,9 & 62,11 \\
\hline \multirow[t]{8}{*}{5} & Amostra seca ao ar & 8,2 & - & $29 *$ & 724,5 \\
\hline & Amostra com umidade natural & 24,4 & - & $0,03 *$ & 11,12 \\
\hline & Sucção imposta por $\mathrm{NaCl}$ saturado & 7,6 & 24 & 40 & 1155,7 \\
\hline & Sucção imposta por $\mathrm{KCl}$ saturado & 9,0 & 24 & 24 & 707,85 \\
\hline & Sucção imposta por $\mathrm{BaCl}_{2} \cdot 2 \mathrm{H}_{2} \mathrm{O}$ saturado & 9,7 & 25 & 15 & 499,22 \\
\hline & Sucção imposta por $\mathrm{NaCl}-5000 \mathrm{kPa}$ & 12,3 & 24 & 5 & 189,32 \\
\hline & Sucção imposta por $\mathrm{NaCl}-3000 \mathrm{kPa}$ & 13,0 & 23,2 & 3 & 129,15 \\
\hline & Sucção imposta por $\mathrm{NaCl}-1000 \mathrm{kPa}$ & 17,1 & 23,2 & 1 & 51,04 \\
\hline
\end{tabular}

\footnotetext{
*Sucção Total obtida da Curva de Retenção - Método do Dessecador de Vácuo.
} 
Os resultados de umidade de equilíbrio para cada sucção imposta nas amostras utilizadas para os ensaios edométricos (Tabela 50), foram muito próximos aos determinados através da curva de retenção obtida no dessecador de vácuo, o que sugere a eficiência deste método, independente do tamanho da amostra de material analisada (em média 7 por $2 \mathrm{~cm}$ e 4,5 por $1,2 \mathrm{~cm}$ para as amostras de adensamento e curva de retenção respectivamente).

TABELA 51. Valores de sucção total em função da temperatura, umidade relativa para a solução salina de Cloreto de sódio saturado

\begin{tabular}{cccc}
\hline $\begin{array}{c}\text { Temperatura } \\
{ }^{\circ} \mathrm{C}\end{array}$ & Umidade relativa & RT/Mg & $\begin{array}{c}\text { Sucção Total } \\
(\mathrm{kPa})\end{array}$ \\
\hline 15 & & & 37.897 \\
20 & 75.6 & 135.485 & 38.737 \\
25 & 75.5 & 137.837 & 39.770 \\
30 & 75.3 & 140.189 & 40.817 \\
35 & 75.1 & 142.541 & 41.877 \\
40 & 74.9 & 144.894 & 42.950 \\
\hline
\end{tabular}

TABELA 52. Valores de sucção total em função da temperatura, umidade relativa para a solução salina de Cloreto de potássio saturado

\begin{tabular}{cccc}
\hline $\begin{array}{c}\text { Temperatura } \\
{ }^{\circ} \mathrm{C}\end{array}$ & Umidade relativa & $\mathrm{RT} / \mathrm{Mg}$ & $\begin{array}{c}\text { Sucção Total } \\
(\mathrm{kPa})\end{array}$ \\
\hline 15 & 85.9 & 135.485 & 20.592 \\
20 & 85.1 & 137.837 & 22.239 \\
25 & 84.3 & 140.189 & 23.943 \\
30 & 83.6 & 142.541 & 25.533 \\
35 & 83.0 & 144.894 & 26.998 \\
40 & 82.3 & 147.246 & 28.683 \\
\hline
\end{tabular}

TABELA 53. Valores de sucção total em função da temperatura, umidade relativa para a solução salina de Cloreto de bário saturado

\begin{tabular}{cccc}
\hline $\begin{array}{c}\text { Temperatura } \\
\mathrm{C}\end{array}$ & Umidade relativa & $\mathrm{RT} / \mathrm{Mg}$ & $\begin{array}{c}\text { Sucção Total } \\
(\mathrm{kPa})\end{array}$ \\
\hline 15 & 92.0 & 135.485 & 11297 \\
20 & 91.0 & 137.837 & 13000 \\
25 & 90.0 & 140.189 & 14770 \\
30 & 89.0 & 142.541 & 16611 \\
35 & 88.0 & 144.894 & 18522 \\
40 & 87.0 & 147.246 & 20506 \\
\hline
\end{tabular}

Nas Tabelas 51, 52 e 53, a relação $\mathrm{RT} / \mathrm{Mg}$ é determinada por: $\mathrm{R}=$ constante de gases perfeitos $\left(8,3143 \mathrm{~J}_{\mathrm{mol} \mathrm{K}}^{-1}\right) ; \mathrm{T}=$ temperatura absoluta; $\mathrm{M}=$ massa molar da água $\left(18,016 \mathrm{~g} \mathrm{~mol}^{-1}\right)$ e $\mathrm{g}=$ aceleração gravitacional $\left(9,81 \mathrm{~ms}^{-2}\right)$. 


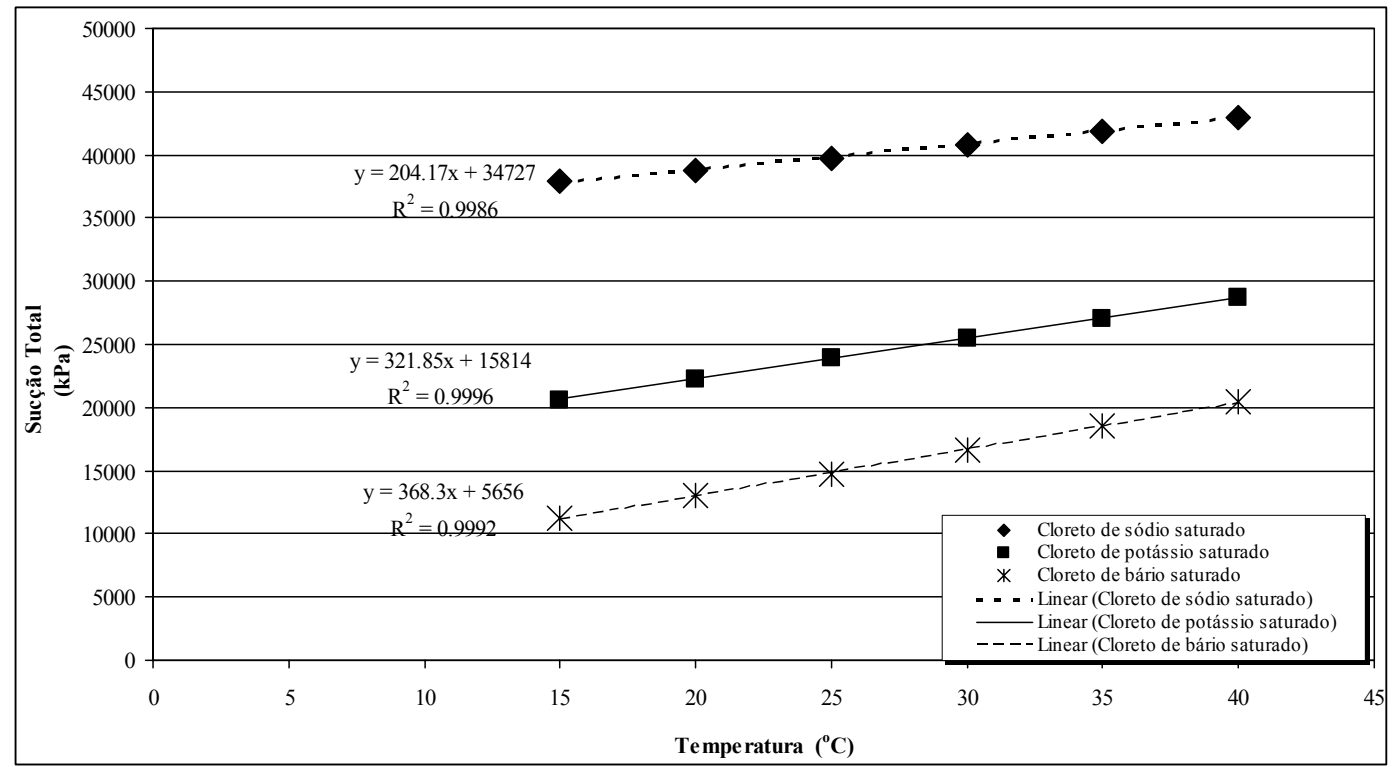

FIGURA 114. Correção da sucção total em função da temperatura para as soluções salinas saturadas de Cloreto de Sódio, Potássio e Bário.

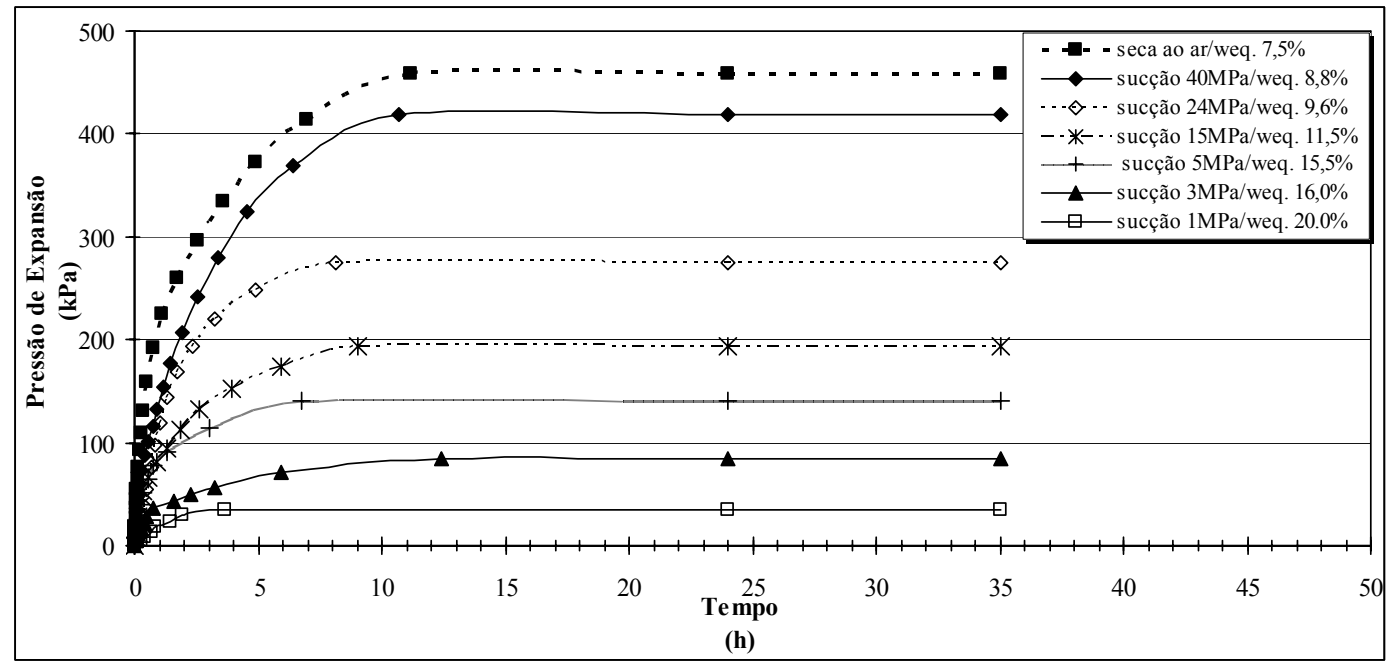

FIGURA 115. Resultados dos ensaios de Pressão de Expansão para o material 1. 


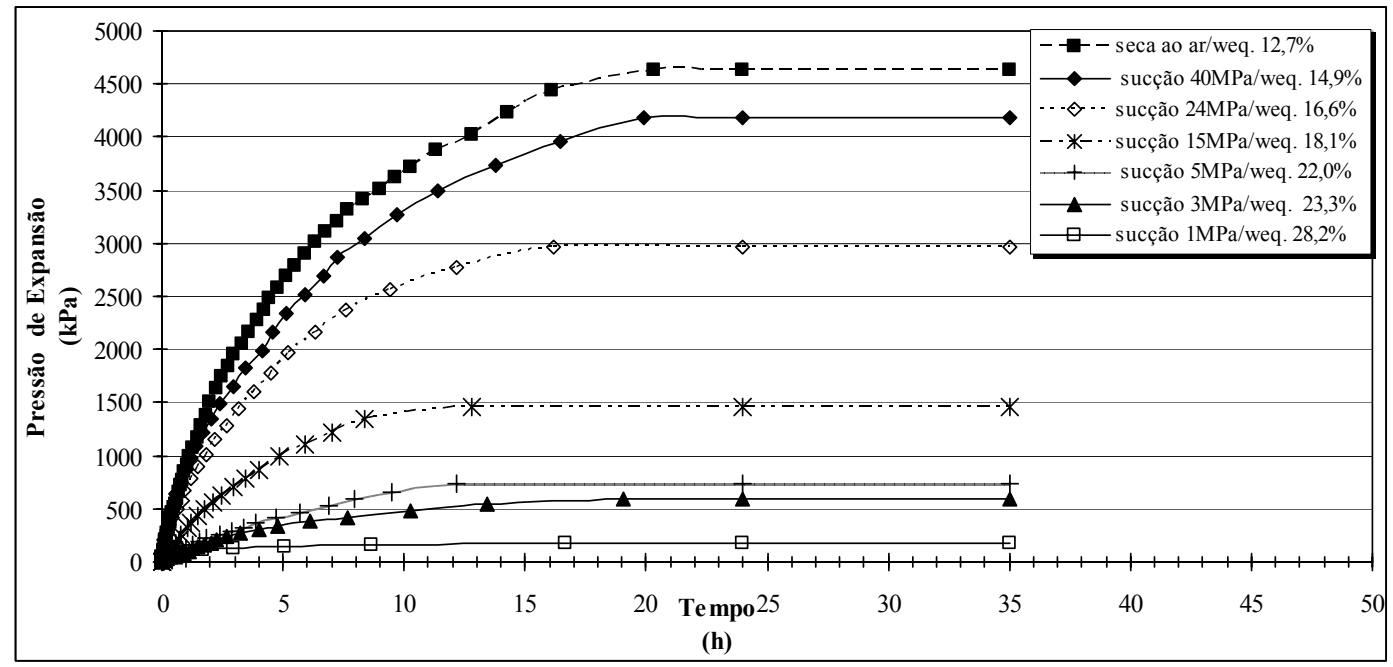

FIGURA 116. Resultados dos ensaios de Pressão de Expansão para o material 2.

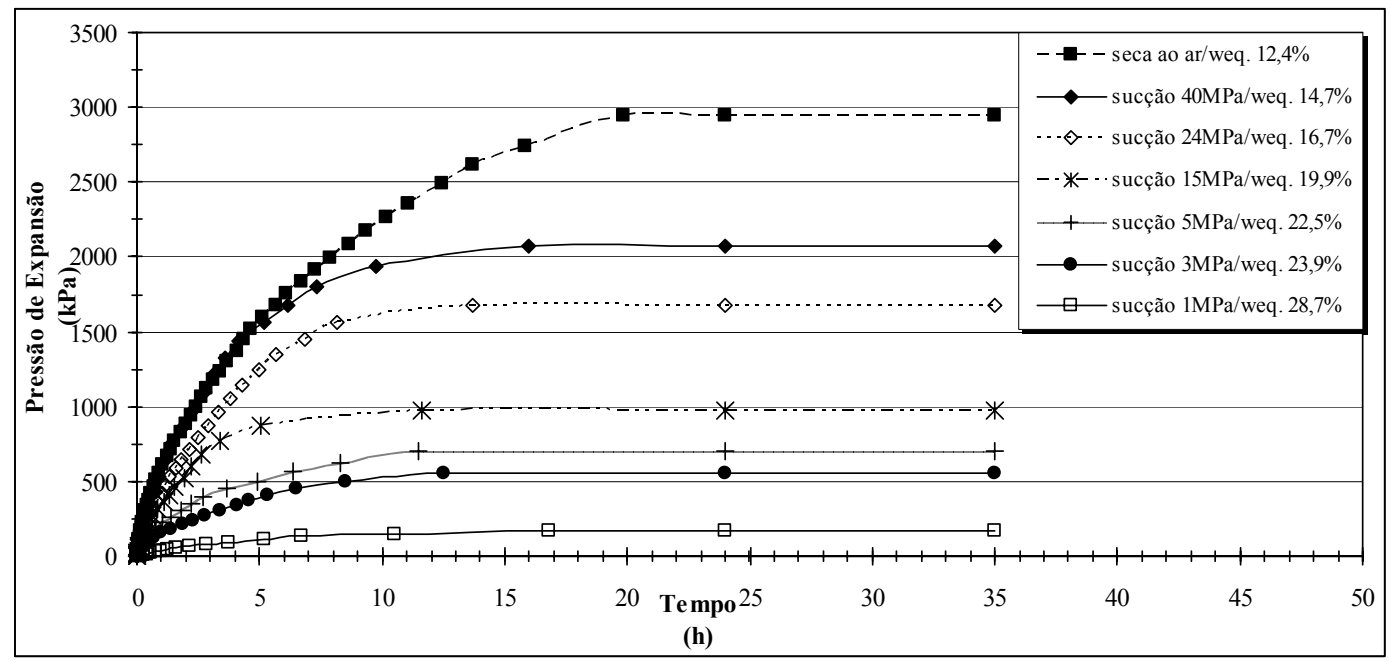

FIGURA 117. Resultados dos ensaios de Pressão de Expansão para o material 3. 


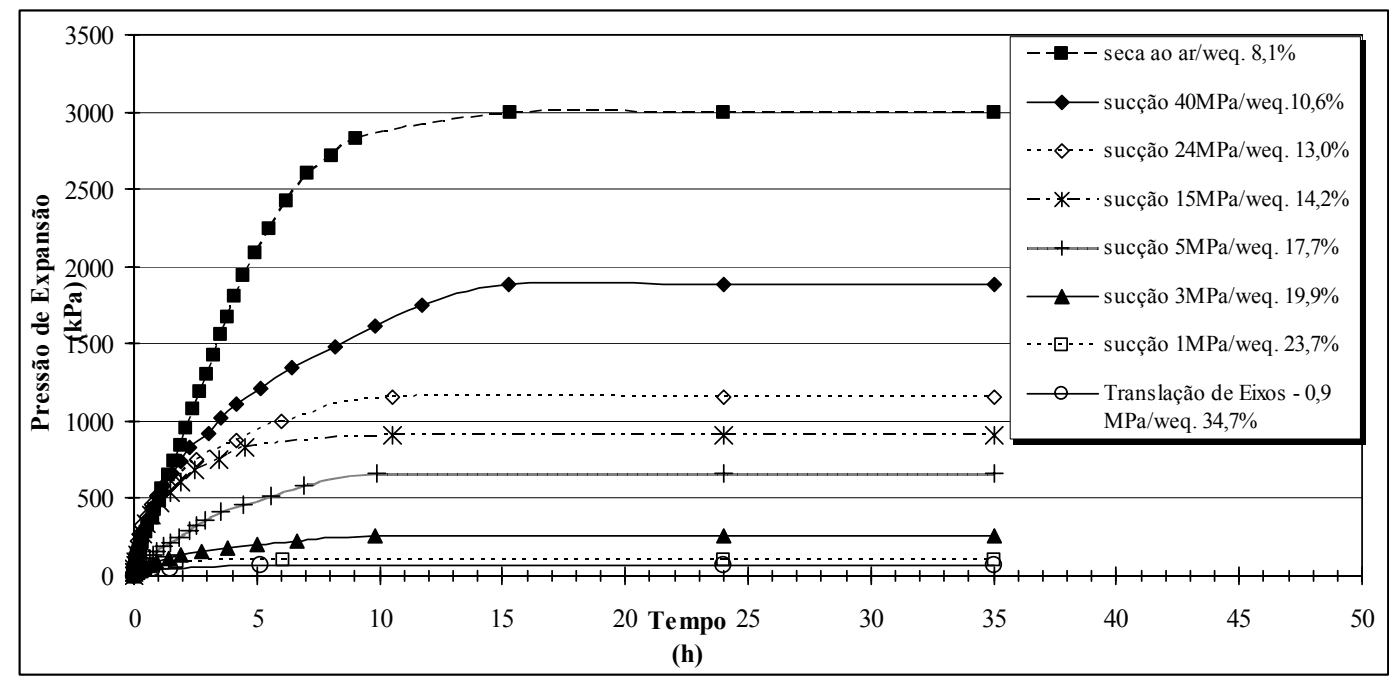

FIGURA 118. Resultados dos ensaios de Pressão de Expansão para o material 4.

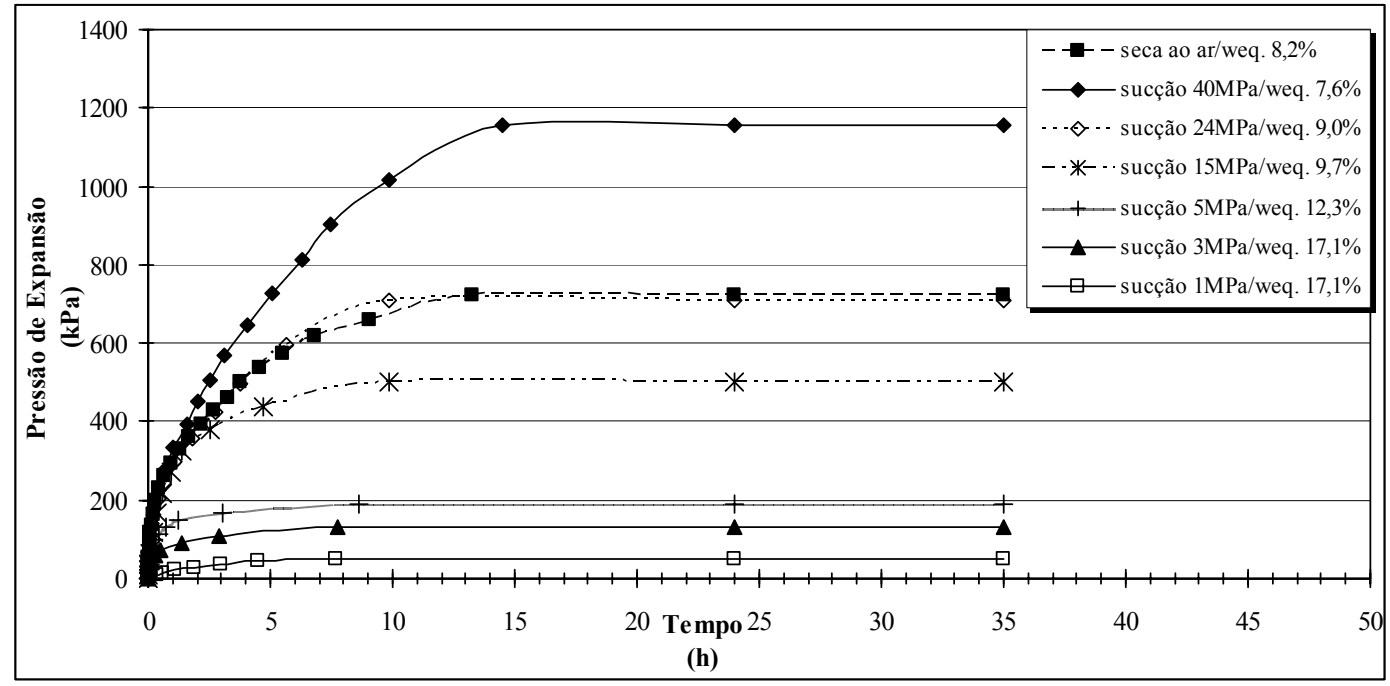

FIGURA 119. Resultados dos ensaios de Pressão de Expansão para o material 5.

Como era esperado, a partir da Tabela 50 e dos gráficos das Figuras 115 a 119, em cada material se observou que os valores de pressão de expansão são maiores com o aumento da sucção em que a amostra se encontrava antes do umedecimento do material. Essas pressões são maiores quando a água intersticial se encontra em tamanhos de poros cada vez menores, o que gera forças de repulsão cada vez maiores, devido às reações físico químicas entre a água e o solo como já comentado anteriormente.

A relação entre a pressão de expansão e o tamanho dos poros, também é observada nos diferentes materiais, pois quando comparados os resultados de pressão de expansão para os cinco materiais, observa-se que, estes são maiores de acordo com os 
valores percentuais estimados de meso e microporos (Tabela 13). De forma geral, estes resultados mostram grande coerência, visto que, o potencial expansivo torna-se crescente em relação aos materiais $1,5,4,3$ e 2 .

\subsubsection{Ensaios edométricos com imposição de umidade relativa}

Os resultados dos ensaios realizados nos edômetros com imposição de umidade relativa estão representados na Tabela 54.

TABELA 54. Resultados obtidos para o ensaio de expansibilidade realizados nos Edômetros com imposição de umidade relativa para as amostras dos materiais 3 e 5

\begin{tabular}{|c|c|c|c|c|c|}
\hline Material & Descrição & $\begin{array}{c}\mathrm{W}_{\text {equilibrio }} \\
(\%)\end{array}$ & $\begin{array}{c}\mathrm{T}_{\text {equilibrio }} \\
\left({ }^{0} \mathrm{C}\right)\end{array}$ & $\begin{array}{c}\text { Sucção Total } \\
(\mathrm{kPa})\end{array}$ & $\begin{array}{c}\text { Pressão de } \\
\text { Expansão } \\
(\mathrm{kPa})\end{array}$ \\
\hline \multirow[t]{6}{*}{3} & Sução imposta por $\mathrm{NaCl}$ saturado & 13,3 & 23 & 39423,0 & 0 \\
\hline & Sucção imposta por $\mathrm{KCl}$ saturado & 15,7 & 25 & 23860,0 & 0 \\
\hline & Sucção imposta por $\mathrm{BaCl}_{2} \cdot 2 \mathrm{H}_{2} \mathrm{O}$ saturado & 17,8 & 25,3 & 14974,0 & 0 \\
\hline & Suç̧ão imposta por $\mathrm{NaCl}-5 \mathrm{MPa}$ & 21,6 & 23,4 & 4968,4 & 0 \\
\hline & Sucção imposta por $\mathrm{NaCl}-3 \mathrm{MPa}$ & 23,0 & 23,3 & 2981,2 & 0 \\
\hline & Suç̧ão imposta por $\mathrm{NaCl}-1 \mathrm{MPa}$ & 29,4 & 22,3 & 990,9 & 0 \\
\hline \multirow[t]{6}{*}{5} & Sucção imposta por $\mathrm{NaCl}$ saturado & 7,6 & 23 & 39423,0 & 0 \\
\hline & Sucção imposta por KCl saturado & 8,9 & 25 & 23860,0 & 0 \\
\hline & Sucção imposta por $\mathrm{BaCl}_{2} \cdot 2 \mathrm{H}_{2} \mathrm{O}$ saturado & 10,1 & 25,3 & 14974,0 & 0 \\
\hline & Sucção imposta por $\mathrm{NaCl}-5 \mathrm{MPa}$ & 11,2 & 23,4 & 4968,4 & 0 \\
\hline & Sucção imposta por $\mathrm{NaCl}-3 \mathrm{MPa}$ & 12,7 & 23,3 & 2981,2 & 0 \\
\hline & Suç̧ão imposta por $\mathrm{NaCl}-1 \mathrm{MPa}$ & 17,7 & 22,3 & 990,9 & 0 \\
\hline
\end{tabular}

Na Tabela 55 são apresentados os resultados obtidos nos dessecadores para as amostras dos materiais $1,2,3$ e 4 .

Observou-se valores nulos para as pressões de expansão provenientes dos edômetros baseados na técnica de imposição de umidade relativa (Tabela 54). Este fato, poderia ocorrer, provavelmente, devido às variações de umidade entre um e outro estágio de sucção que não teriam sido suficientes para gerar pressões de expansão expressivas. Por essa razão, tentou-se elucidar essa hipótese com um teste que provocasse uma variação maior de umidade e portanto, uma pressão de expansão mais representativa.

O material 3, já empregado no ensaio da Tabela 54, foi utilizado e o teste consistiu em induzir pressão de expansão ao levar a amostra desde 40MPa de sucção (solução saturada de $\mathrm{NaCl}$ ) diretamente para $1 \mathrm{MPa}$ (solução salina aquosa de $\mathrm{NaCl}$ ), pelos 
procedimentos similares aos empregados no ensaio anterior. Do resultado obtido deste ensaio, como mostra a Tabela 55, se observou que o comportamento do material foi similar aos anteriormente apresentados, ou seja, não houve pressão de expansão.

TABELA 55. Resultados obtidos para o ensaio de expansibilidade realizado no dessecador de vácuo para amostras dos materiais 1, 2, 3 e 4

\begin{tabular}{|c|c|c|c|c|c|}
\hline Material & Descrição & $\begin{array}{c}\mathrm{W}_{\text {equilibrio }} \\
(\%)\end{array}$ & $\begin{array}{c}\mathrm{T}_{\text {equilibrio }} \\
\left({ }^{0} \mathrm{C}\right) \\
\end{array}$ & $\begin{array}{c}\text { Sucção Total } \\
(\mathrm{kPa})\end{array}$ & $\begin{array}{c}\text { Pressão de } \\
\text { Expansão } \\
(\mathrm{kPa})\end{array}$ \\
\hline \multirow[t]{6}{*}{1} & Sucção imposta por $\mathrm{NaCl}$ saturado & 9,2 & 24,4 & 39709,0 & 0 \\
\hline & Sucção imposta por $\mathrm{KCl}$ saturado & 10,4 & 25,0 & 23860,0 & 0 \\
\hline & Sucção imposta por $\mathrm{BaCl}_{2} \cdot 2 \mathrm{H}_{2} \mathrm{O}$ saturado & 11,5 & 23,8 & 14442,0 & 0 \\
\hline & Sucção imposta por $\mathrm{NaCl}-5000 \mathrm{kPa}$ & 15,2 & 23,5 & 4970,5 & 0 \\
\hline & Sucção imposta por $\mathrm{NaCl}-3000 \mathrm{kPa}$ & 16,3 & 24,0 & 2988,9 & 0 \\
\hline & Sucção imposta por $\mathrm{NaCl}-1000 \mathrm{kPa}$ & 19,4 & 22,3 & 990,9 & 0 \\
\hline \multirow[t]{6}{*}{2} & Sucção imposta por $\mathrm{NaCl}$ saturado & 15,7 & 24,4 & 39709,0 & 0 \\
\hline & Sucção imposta por $\mathrm{KCl}$ saturado & 17,6 & 25,0 & 23860,0 & 0 \\
\hline & Sucção imposta por $\mathrm{BaCl}_{2} \cdot 2 \mathrm{H}_{2} \mathrm{O}$ saturado & 19,3 & 23,8 & 14442,0 & 0 \\
\hline & Sucção imposta por $\mathrm{NaCl}-5000 \mathrm{kPa}$ & 21,8 & 23,5 & 4970,5 & 0 \\
\hline & Sucção imposta por $\mathrm{NaCl}-3000 \mathrm{kPa}$ & 22,9 & 24,0 & 2988,9 & 0 \\
\hline & Sucção imposta por $\mathrm{NaCl}-1000 \mathrm{kPa}$ & 28,8 & 22,3 & 990,9 & 0 \\
\hline$* 3$ & Sucção imposta por $\mathrm{NaCl}-1000 \mathrm{kPa}$ & 29,4 & 22,3 & 990,9 & 0 \\
\hline \multirow[t]{6}{*}{4} & Sucção imposta por $\mathrm{NaCl}$ saturado & 12,4 & 24,0 & 39627,0 & 0 \\
\hline & Sucção imposta por $\mathrm{KCl}$ saturado & 14,7 & 24,4 & 23667,0 & 0 \\
\hline & Sucção imposta por $\mathrm{BaCl}_{2} \cdot 2 \mathrm{H}_{2} \mathrm{O}$ saturado & 15,9 & 25,0 & 14864,0 & 0 \\
\hline & Sucção imposta por $\mathrm{NaCl}-5000 \mathrm{kPa}$ & 17,3 & 23,8 & 4976,4 & 0 \\
\hline & Sucção imposta por $\mathrm{NaCl}-3000 \mathrm{kPa}$ & 19,6 & 23,5 & 2983,5 & 0 \\
\hline & Sucção imposta por $\mathrm{NaCl}-1000 \mathrm{kPa}$ & 23,2 & 22,3 & 990,9 & 0 \\
\hline
\end{tabular}

*Amostra submetida inicialmente a sucção de 39505,0 kPa, passando em seguida para sucção de 990,9 $\mathrm{kPa}$.

Em geral, os resultados de pressão de expansão foram nulos (Tabelas 54 e 55), apesar de terem sido aplicados os mesmos valores de sucção que nos ensaios realizados nos edômetros convencionais e utilizando o mesmo método, ou seja, imposição de umidade relativa por meio de soluções salinas. O contraste destes resultados é significativo em relação aos obtidos nos edômetros convencionais, onde no procedimento de ensaio deste último, as amostras após imposição da sucção, foram umedecidas por inundação com água destilada e experimentaram fortes expansões (Tabela 50).

A diferença entre os ensaios, é que no caso dos ensaios edométricos com imposição de umidade relativa, a mudança de umidade se faz muito lentamente, por 
meio de transferência de água na fase vapor, podendo residir neste fato, a explicação para a diferença de comportamento observada.

\subsubsection{Análise dos resultados dos ensaios de caracterização versus ensaios de expansão}

Inicialmente foi realizada uma análise retratando individualmente alguns parâmetros que influenciam no potencial expansivo com as pressões de expansão provenientes dos ensaios em edômetros convencionais com sucção imposta pelo método do dessecador de vácuo para cada material. Foram relacionados parâmetros como IP $(\%), \rho_{\mathrm{d}}\left(\mathrm{g} / \mathrm{cm}^{3}\right)$, porcentagem de argila, índice de vazios, LL (\%), CTC (argila), VB (g/100g de solo) e Acb (g/100g de argila). No entanto, essas relações mostraram-se inconsistentes, provavelmente, porque nestes materiais o fenômeno expansivo é gerado pela influência destes fatores em conjunto, o que levou a realizar uma nova análise.

Pereira e Pejon (1999), realizaram uma análise preliminar do potencial expansivo dos materiais argilosos da Formação Guabirotuba, a partir da correlação de valores de porcentagem de argila versus VB versus expansão, delimitando áreas onde predominavam materiais com potenciais expansivos qualificados como: muito alto, alto, médio e baixo. Como os autores após observações no mesmo material, obtiveram resultados satisfatórios a partir desta análise, esta foi aprimorada, relacionando para este trabalho a porcentagem de argila e VB (g/100g de solo) versus Pressão de Expansão para cada sucção imposta, gerando um índice aqui denominado de Índice Mineralógico (IM), que é expresso pela equação 29. A escolha dos atributos porcentagem de argila e VB, se deve a que, são dois fatores de grande influência sobre a expansibilidade de um determinado material, sendo que, o teor e a atividade da argila respectivamente, vão indicar se o material é ou não potencialmente expansivo, além de serem atributos de fácil obtenção.

$\mathrm{IM}=\frac{\% \operatorname{argila} * \mathrm{VB}}{100}$

Onde: $\mathrm{IM}=$ índice mineralógico. 
Os valores do índice IM (Tabela 56) para cada material e pressão de expansão $(\mathrm{kPa})$ correspondentes às sucções impostas (Tabela 50) foram plotados no gráfíco da Figura 120.

Foram utilizados estes atributos com o propósito de avaliar a influência da mineralogia na expansão destes materiais à medida que as sucções aumentavam. Podese observar, na Figura 120, através dos coeficientes de determinação $\left(\mathrm{r}^{2}\right)$, que à medida que a sucção aumenta, diminui a influência dos atributos mineralógicos na previsão do potencial expansivos dos materiais.

TABELA 56. Parâmetros usados e resultados da relação entre eles

\begin{tabular}{cccc} 
Material & Argila (\%) & VBmédio & IM \\
\hline 1 & 58 & 10,0 & 5,80 \\
2 & 75 & 18,0 & 13,53 \\
3 & 78 & 18,2 & 14,18 \\
4 & 67 & 14,6 & 9,76 \\
5 & 30 & 10,1 & 3,02 \\
\hline
\end{tabular}

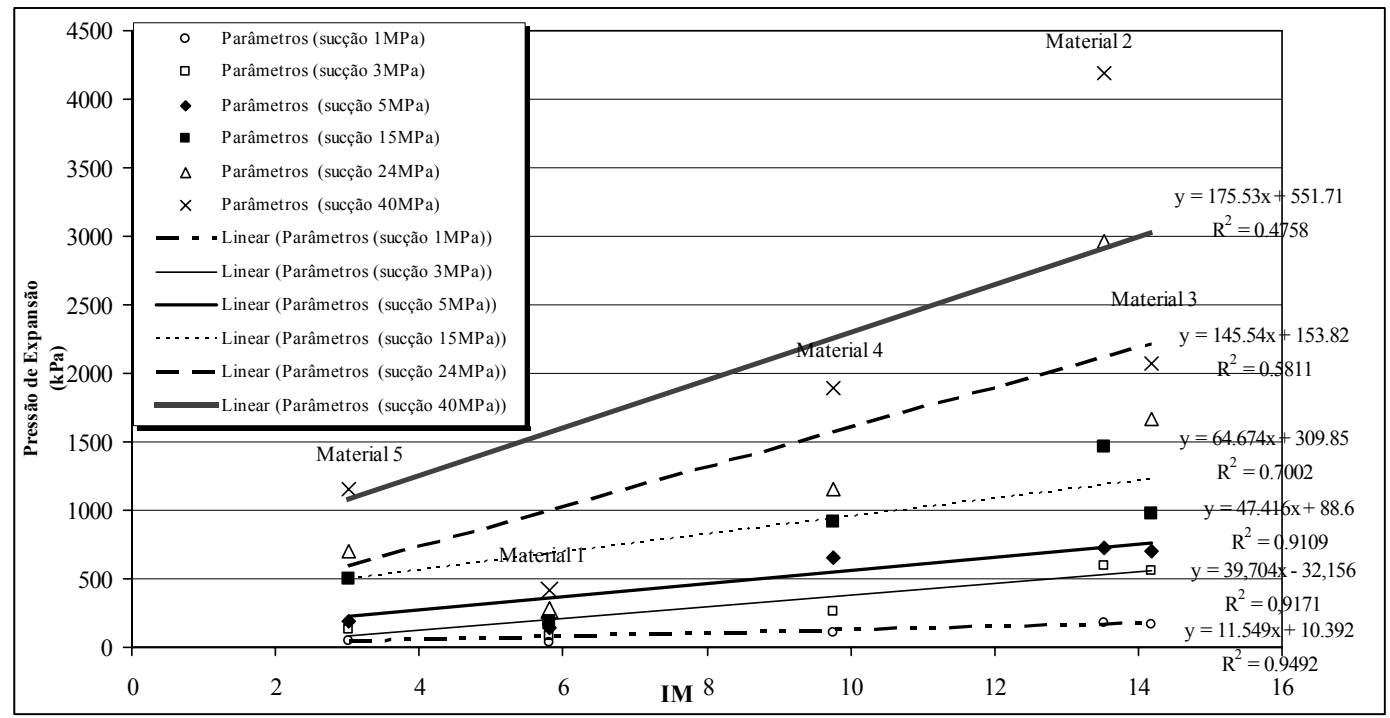

FIGURA 120. Resultados do IM e Pressões de Expansão para as diferentes sucções impostas.

A partir dos resultados obtidos através do (IM) optou-se por incorporar uma relação entre parâmetros provenientes dos índices físicos $\left(\rho_{\mathrm{d}}\left(\mathrm{g} / \mathrm{cm}^{3}\right)\right)$, índices de consistência (IP (\%)), granulometria (\% argila) e índices físico-químicos (VB) versus os resultados de Pressão de Expansão provenientes de cada sucção imposta. Estes 
parâmetros foram escolhidos, dado que, cada um deles, têm uma relação direta com a pressão de expansão, ou seja, quanto maior o valor de cada um deles incorrerá numa maior pressão de expansão.

A correlação consistiu num produto entre estes parâmetros da seguinte forma :

$\mathrm{ICM}=\underline{\mathrm{IP} *} \underline{\mathrm{d}}_{\mathrm{d}} \underline{* 0 \operatorname{argila} * \mathrm{VB}}$

$$
10.000
$$

Onde: $\mathrm{ICM}=$ índice característico dos materiais.

A Tabela 57 demonstra os dados utilizados e os resultados obtidos do ICM (equação 30).

TABELA 57. Parâmetros utilizados e resultados da relação entre eles

\begin{tabular}{cccccc}
\hline Material & IP $(\%)$ & $\rho_{\mathrm{d}}\left(\mathrm{g} / \mathrm{cm}^{3}\right)$ & Argila $(\%)$ & VBmédio & ICM \\
\hline 1 & 54,5 & 1,251 & 58 & 10,0 & 3,96 \\
2 & 55,5 & 1,170 & 75 & 18,0 & 8,78 \\
3 & 39,4 & 1,221 & 78 & 18,2 & 6,82 \\
4 & 47,6 & 1,044 & 67 & 14,6 & 4,85 \\
5 & 18,1 & 1,499 & 30 & 10,1 & 0,82 \\
\hline
\end{tabular}

Os dados dos índices ICM (equação 30) para cada material versus pressão de expansão $(\mathrm{kPa})$ correspondentes às sucções impostas (Tabela 50) foram plotados em gráfico da Figura 121.

Exceto para o Material 1, o acréscimo do índice mostrou a tendência do aumento da pressão de expansão e adicionalmente estas duas variáveis (ICM e Pressão de expansão) descrevem uma trajetória que pode ser ajustada com a finalidade de relacioná-las. Os ajustes foram satisfatórios em todos os casos $\left(\mathrm{r}^{2}>0,9\right)$ e mostraram que as trajetórias podem ser descritas por equações polinômicas de segundo grau. Isto sugere que para um mesmo valor do índice (ICM) haverá um acréscimo cada vez maior da pressão de expansão à medida que a sucção aumenta. 


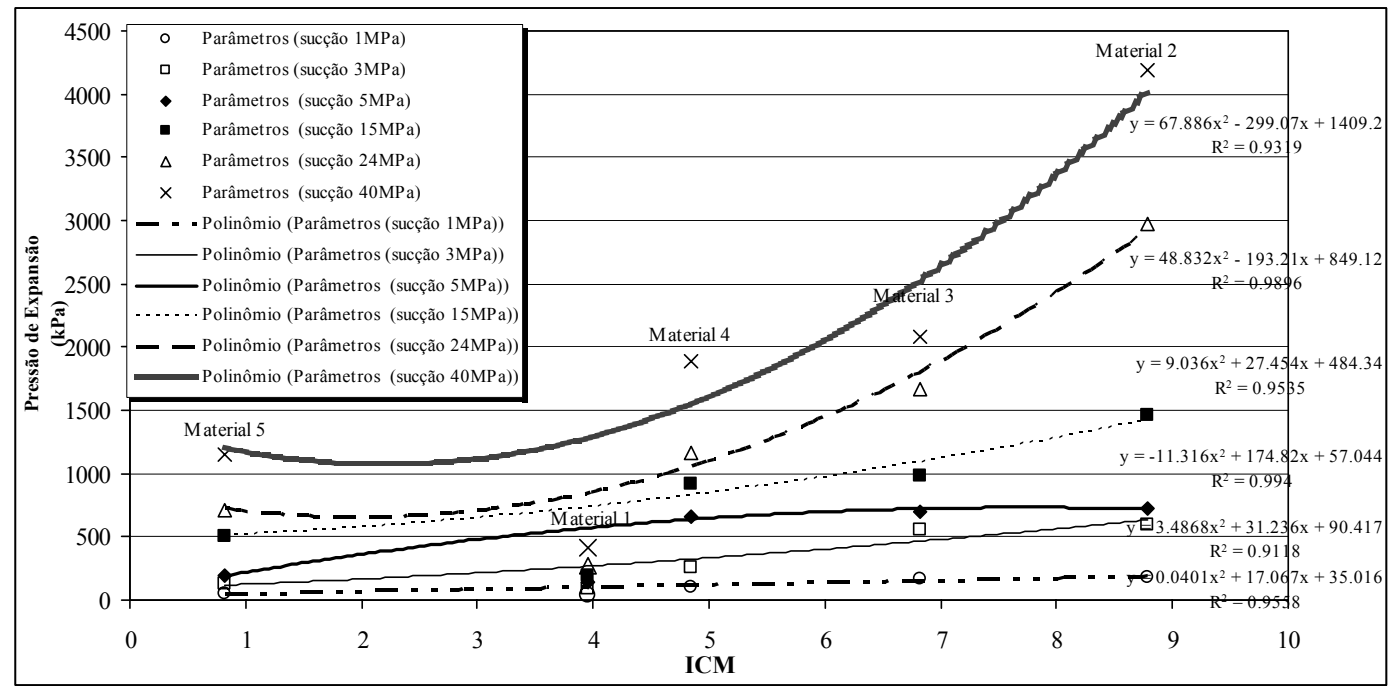

FIGURA 121. Resultados do ICM e Pressões de Expansão para as diferentes sucções impostas.

\subsubsection{Análise dos resultados de Pressão de Expansão (kPa) versus Sucção Total (kPa)}

Estão representados na Figura 122 todos os resultados de Pressão de Expansão $(\mathrm{kPa})$ versus Sucção Total $(\mathrm{kPa})$ obtidos para os cinco materiais. Observa-se, de forma geral, que à medida que a sucção aumenta os valores de pressão de expansão para cada material tendem também a aumentar descrevendo cada um deles um comportamento aproximadamente linear. Este resultado está de acordo com o observado no item anterior para o índice característico dos materiais (ICM), pois quando o material tem características iguais, as variações de sucção passam a ser o fator preponderante na definição da expansão. 


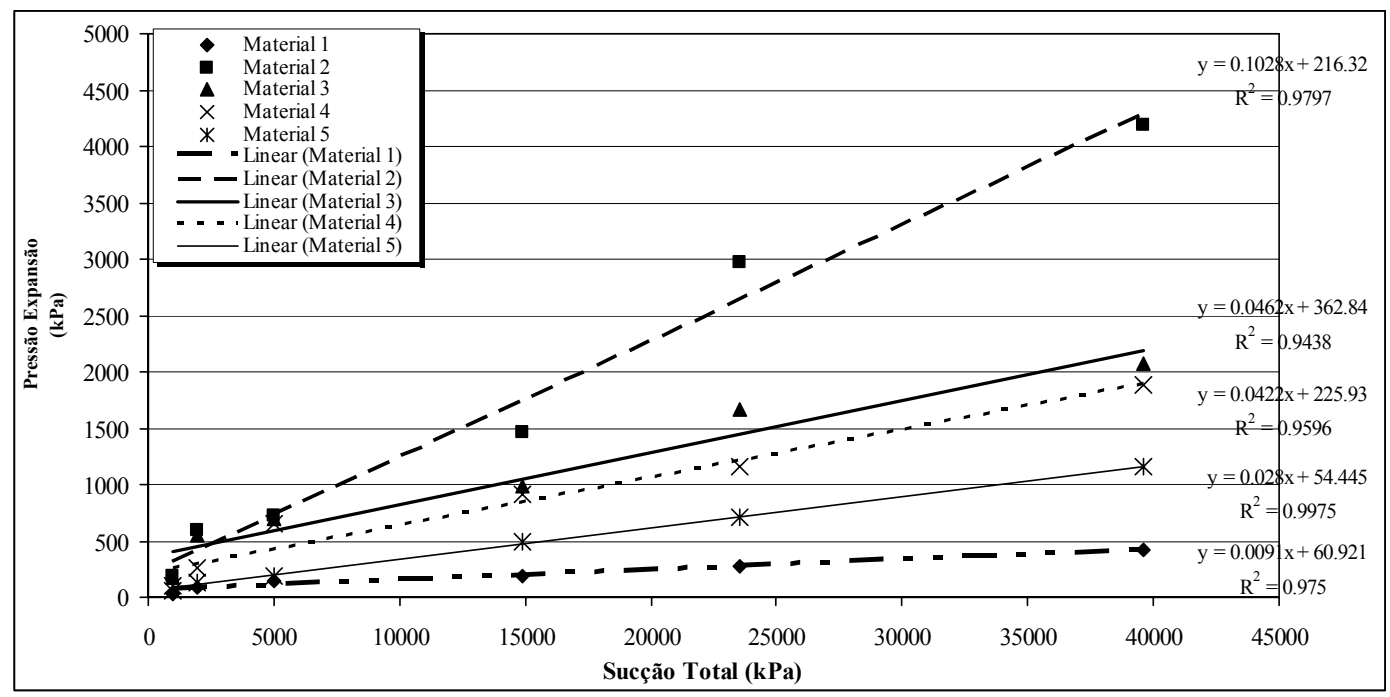

FIGURA 122. Resultados das Pressões de Expansão obtidas para as sucções impostas por umidade relativa.

\subsubsection{Edômetro com controle de sucção de ESCARIO baseado na técnica de Translação de eixos}

Neste equipamento havia somente a possibilidade de impor pressões de ar de até cerca de $900 \mathrm{kPa}$ nas amostras (limitação do sistema de ar comprimido e limitações desconhecidas da câmara edométrica) e por tratar-se de materiais argilosos os resultados dos ensaios não foram satisfatórios devido à necessidade de pressões de ar mais elevadas (teores de umidade mais baixos) para que fossem observadas as deformações nos materiais. Como as amostras numa faixa de 0 a $900 \mathrm{kPa}$ apresentaram deformação praticamente nula optou-se por realizar um teste com uma amostra do material impondo na mesma a sucção máxima permitida $(900 \mathrm{kPa})$. Para tal propósito utilizou-se um corpo de prova indeformado com diâmetro de $6,56 \mathrm{~cm}$ e altura de $2,04 \mathrm{~cm}$. Atingido o equilíbrio (sucção matricial $(\mathrm{kPa})$ e teor de umidade $(\%)$ ) realizouse com a amostra um ensaio edométrico convencional utilizando o método a volume constante, tal como descrito no item 4.2.4.1, com a finalidade de observar se haveria grande diferença na deformação em ambos os processos. O resultado foi satisfatório porque o valor obtido da pressão de expansão foi baixo (Tabela 50 e Figura 118) confirmando a necessidade da utilização de um novo método que permitisse alcançar sucções mais altas para o estudo. 


\subsection{Ensaios de Adensamento}

Nos gráficos das Figuras 123, 124, 125, 126 e 127, podem ser observados os resultados dos ensaios de adensamento para as amostras inicialmente submetidas aos ensaios de expansão nos edômetros convencionais. Como já citado anteriormente, não foi possível a realização deste ensaio para as amostras dos materiais 2, 3 e 4, nas quais foram impostas sucção através de $\mathrm{NaCl}$ saturado (40 MPa); para os materiais 2 e 3, nas quais foram impostas sucção a partir de $\mathrm{KCl}$ saturado $(24 \mathrm{MPa})$ e para o material 2 no qual foi imposta sucção através de Cloreto de Bário saturado (15MPa).

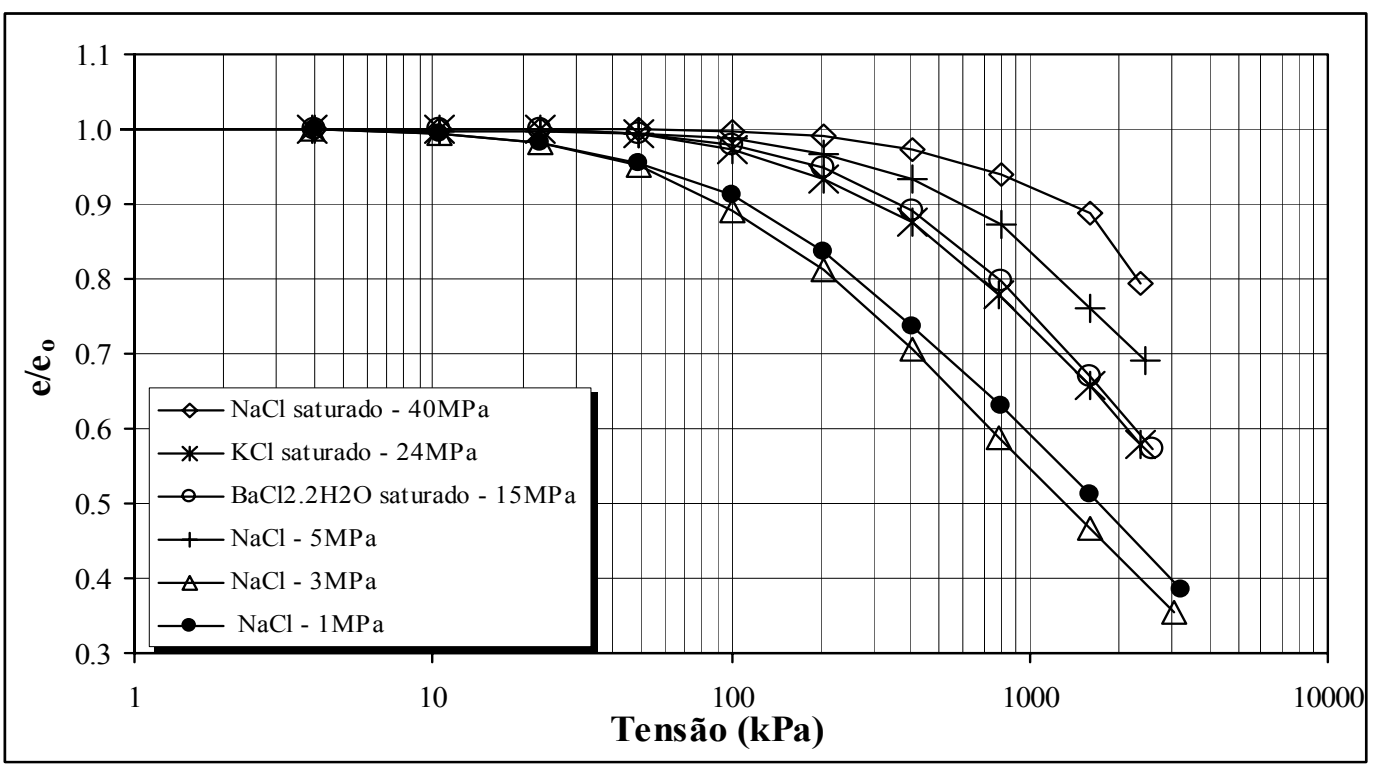

FIGURA 123. Resultados do ensaio de adensamento para o material 1. 


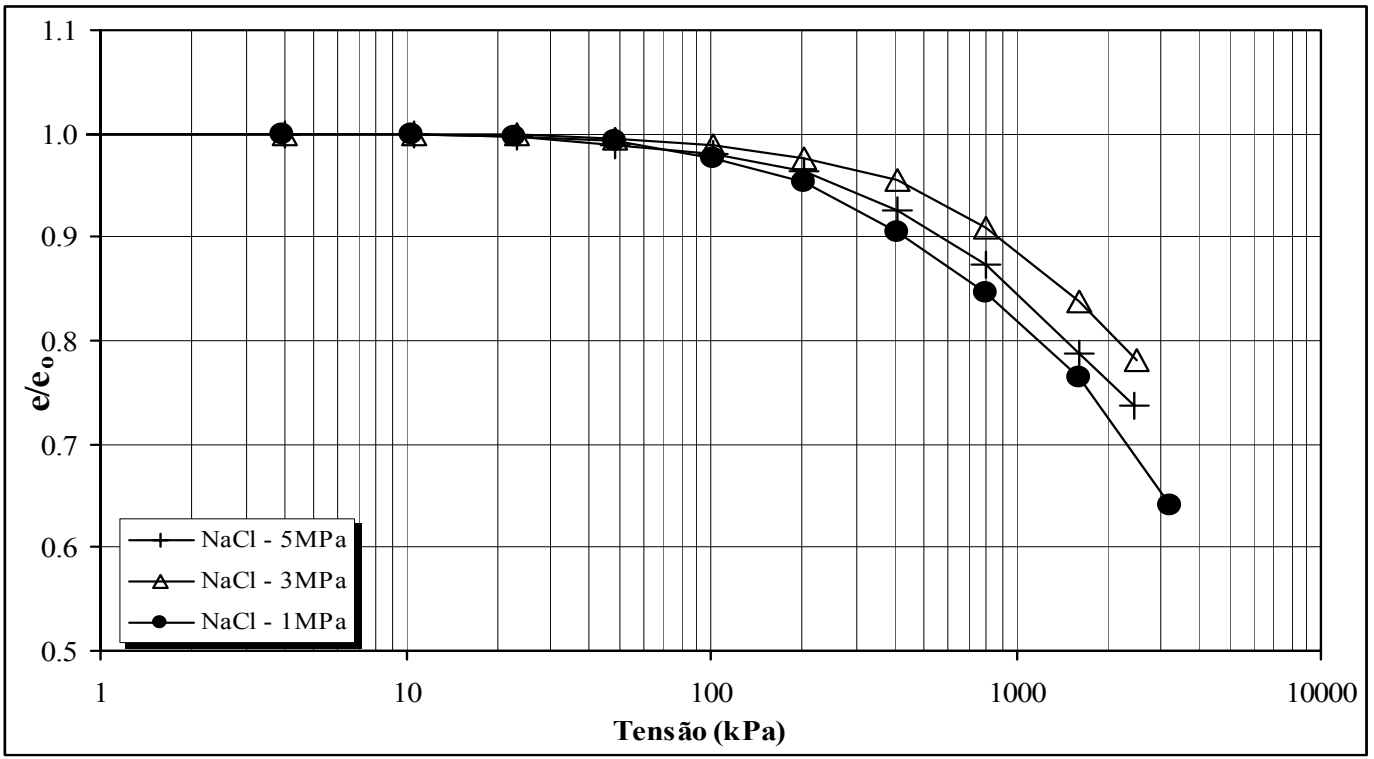

FIGURA 124. Resultados do ensaio de adensamento para o material 2.

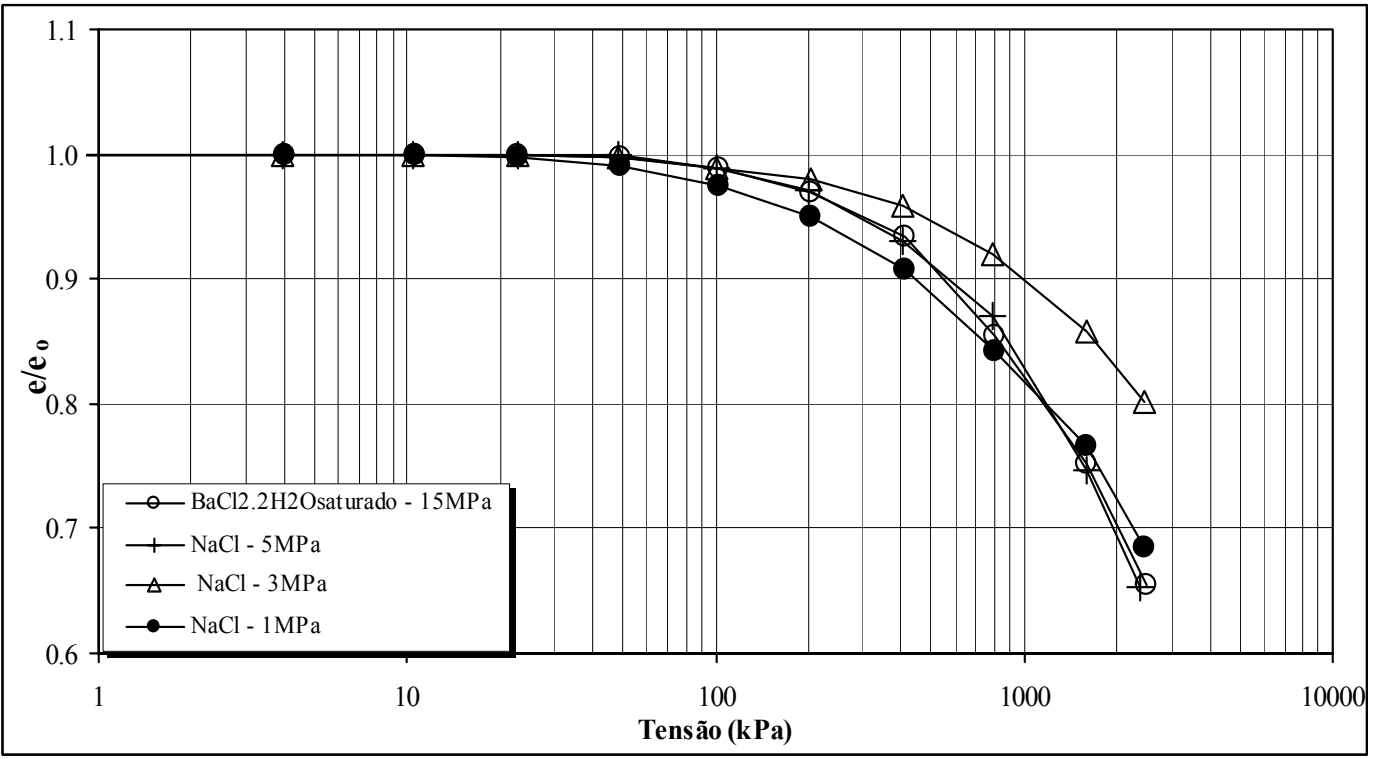

FIGURA 125. Resultados do ensaio de adensamento para o material 3. 


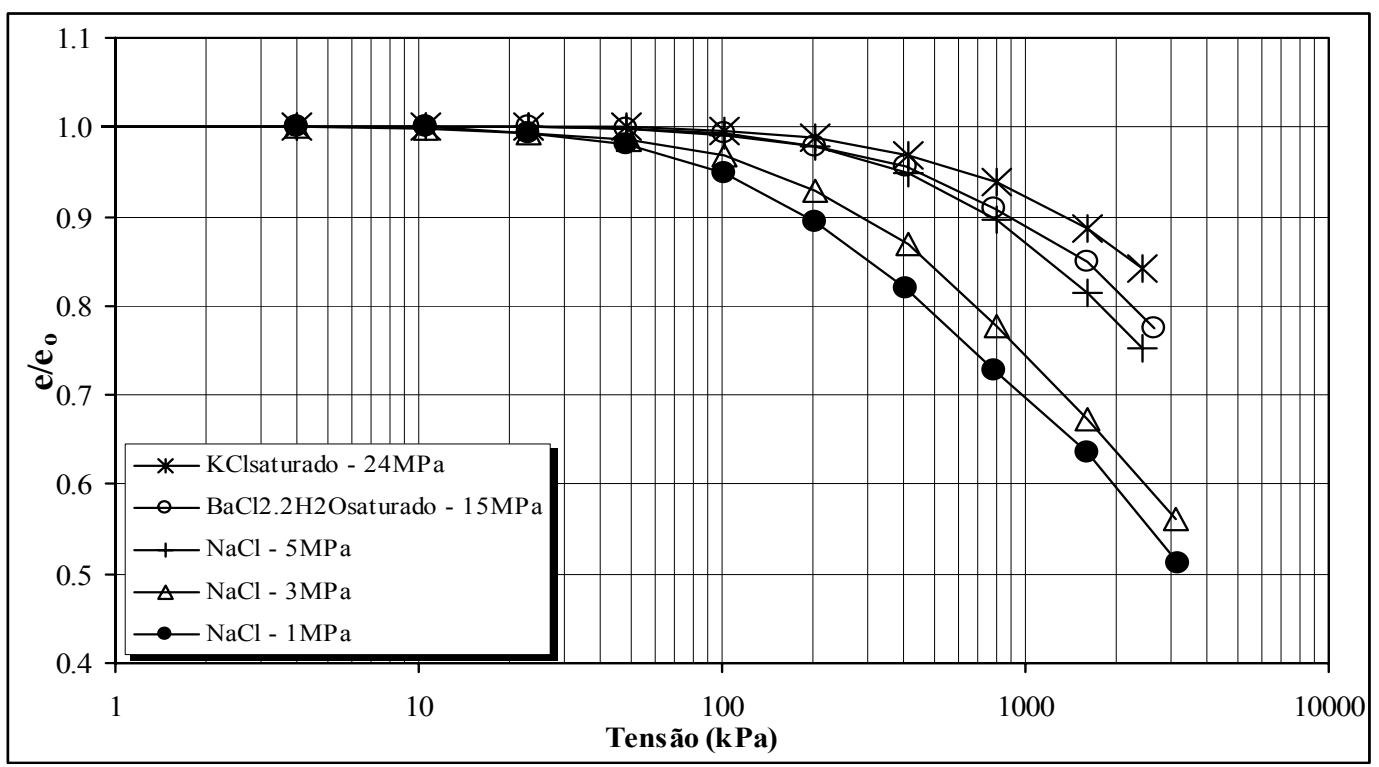

FIGURA 126. Resultados do ensaio de adensamento para o material 4.

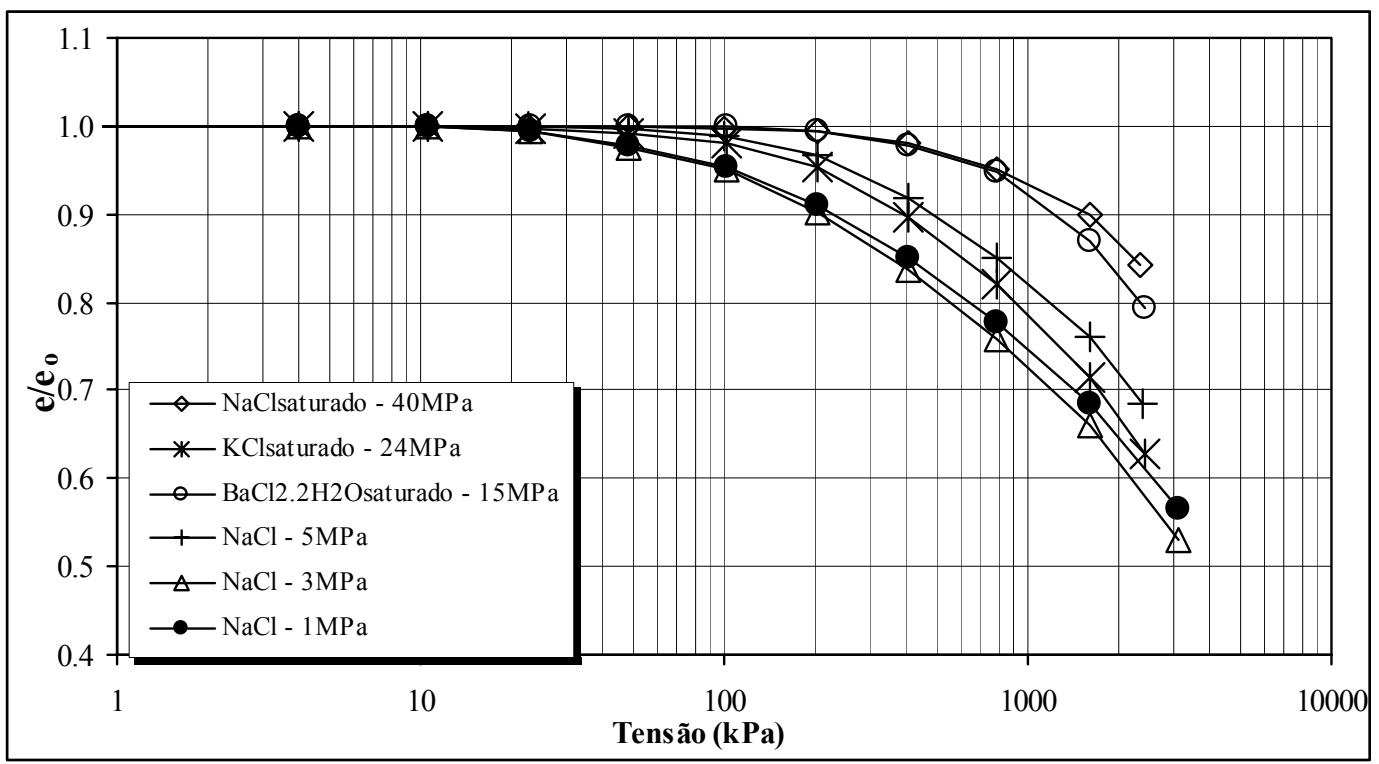

FIGURA 127. Resultados do ensaio de adensamento para o material 5. 
Depois do máximo de carregamento a volume constante, se procedeu ao adensamento da amostra, tal como indicado no item 4.2.5. Isto com a finalidade de poder realizar uma estimativa das tensões de pré-adensamento dos materiais estudados, visto que, como já mencionado, o histórico de tensões é também um fator que influencia no potencial expansivo em materiais com essas características.

Dos ensaios de adensamento, se observou que devido à alta rigidez apresentada pelos materiais em estudo foi impossível uma melhor caracterização da "reta virgem", visto a limitação do equipamento, atingindo-se uma pressão de carregamento máxima de $3200 \mathrm{kPa}$. Esta limitação prejudicou os resultados, provavelmente subestimando os valores. Um resumo dos resultados é mostrado na Figura 128, e expressos como tensão de pré-adensamento $(\mathrm{kPa})$ versus sucção total $(\mathrm{kPa})$ das amostras antes do umedecimento do material.

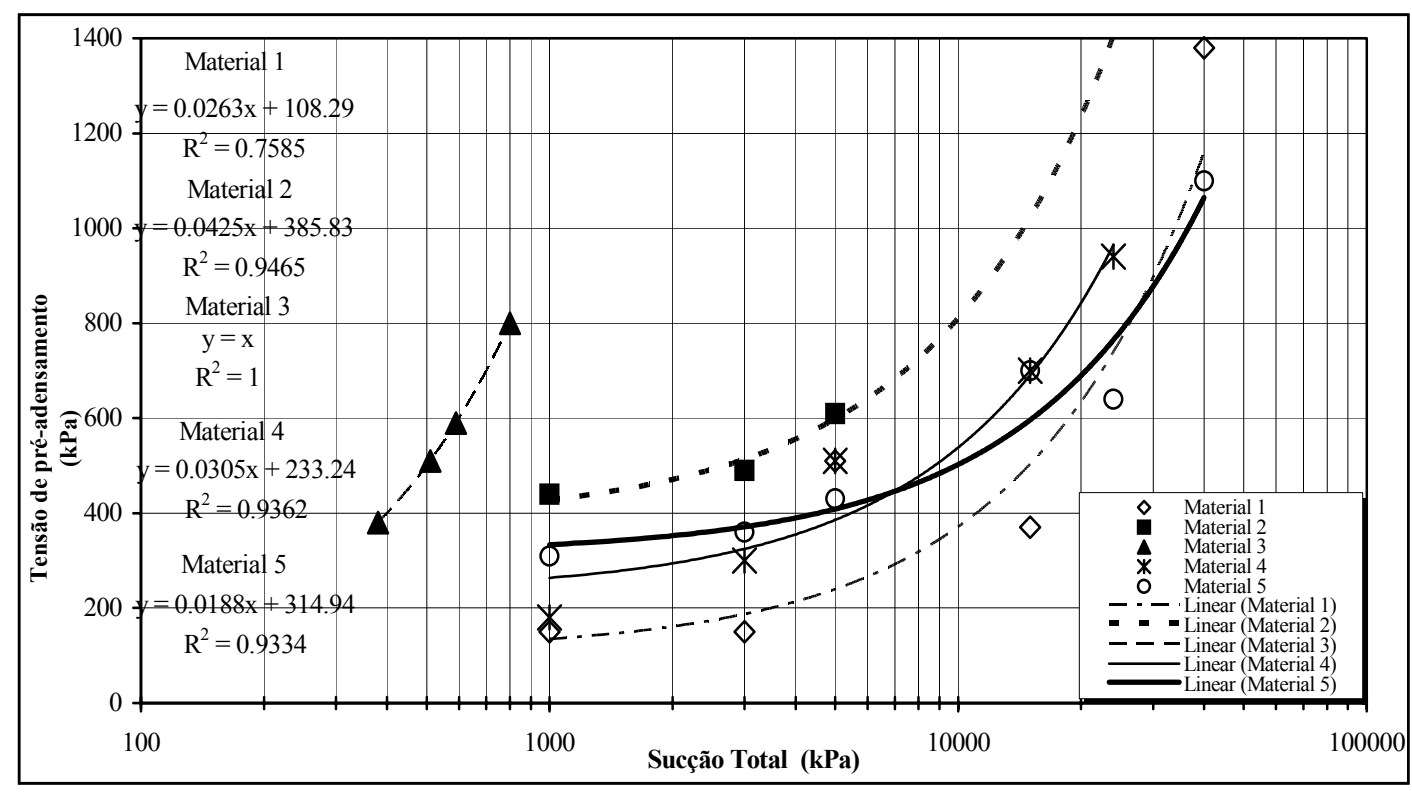

FIGURA 128. Tensão de pré-adensamento versus sucção total (da amostra antes do umedecimento) para os materiais analisados. 
De qualquer forma, como pode ser visto nesta figura a maioria dos valores da tensão de pré- adensamento variaram entre 150 e $1380 \mathrm{kPa}$. Estes valores mostraram-se compatíveis com os encontrados por outros autores (Kormann et al., 1999; Prates, 1999; Duarte, 1999; Nascimento et al., 1994; entre outros) nos materiais da Formação Guabirotuba. De acordo com Nascimento et al. (1994), valores típicos da tensão de préadensamento dos materiais da Formação Guabirotuba situam-se na faixa de 400 a $1000 \mathrm{kPa}$. Estes autores supõem que a razão do pré-adensamento tenha sido mais fortemente influenciada pelo ressecamento (fases climáticas úmidas intercaladas com períodos de semi-aridez), do que devido à sobrecarga posteriormente erodida.

Pode-se observar que para todos os materiais, há uma tendência do aumento dos valores de tensão de pré-adensamento com aumento da sucção da amostra antes do umedecimento do material (Figura 128). Em cada material, esperava-se um mesmo valor de tensão de pré-adensamento para todos os estágios de sucção, pois ao final do ensaio de expansão a volume constante, presume-se que a amostra encontra-se saturada com sucções próximas a zero. No entanto, os gráficos mostram que o acréscimo de tensão de pré-adensamento pode ser provocado por um aumento de rigidez devido a teores de umidade final (após inundação) menores em relação as sucções cada vez maiores impostas antes da inundação da amostra. Este fenômeno estaria relacionado com a histerese relativa ao material pelo processo de umedecimento e que provavelmente é maior com o aumento da sucção inicial da amostra. 


\section{CAPÍTULO 6. CONCLUSÃO}

\subsection{Características gerais dos materiais estudados}

Os ensaios de ATD, ATG, Difração de Raios-X e Adsorção de Azul de Metileno permitiram uma caracterização bem definida da composição mineralógica dos materiais estudados. Foi possível através destas análises, identificar os grupos de argilominerais presentes nos materiais, os quais foram, caulinita, ilita e esmectita, além de minerais como o quartzo e feldspato. A presença do grupo das esmectitas indica o potencial à expansão dos materiais, já que é um dos fatores de maior influência na expansibilidade.

A análise semi-quantitativa realizada pela avaliação dos difratogramas sugeria um potencial de expansão maior para o material 5, médio para o material 3 e menor para os materiais 1,2 e 4, devido à presença de esmectita na fração argila. No entanto, nos ensaios de pressão de expansão, isto não se confirmou. A importância da mineralogia diminuiu em função das porcentagens da fração argila de cada material, sendo que a influência de outros fatores (umidade inicial, plasticidade, $\rho$, sucção, histórico de tensões, etc.) associados à expansão, acabam em alguns casos, sendo determinantes na expansão de cada material. Este resultado demonstrou que o conhecimento da mineralogia da fração argila e da porcentagem desta nos materiais, é importante, mas não é suficiente para avaliar o comportamento expansivo.

Os resultados obtidos nesta pesquisa permitiram comprovar que o índice VB (ensaio de azul de metileno), pode ser utilizado como um indicativo da atividade da fração argila do material e conseqüentemente do seu potencial expansivo, conforme proposto por Pereira (1999). Assim sendo, os materiais estudados podem ser classificados como tendo um potencial expansivo médio para os materiais 1 e 5 , e muito alto para os materiais 2, 3 e 4, o que foi confirmado pelos ensaios de expansão. 
Os resultados de distribuição dos poros dos materiais demonstraram haver relação entre tamanho dos poros, sucção e pressão de expansão. As amostras 2, 3 e 4 que apresentam maior concentração de vazios na faixa de micro e mesoporos apresentaram conseqüentemente as maiores sucções e pressões de expansão.

\subsection{Quanto às características das curvas de retenção de água no solo}

A análise dos ajustes das curvas de retenção aos dados experimentais obtidos pelas técnicas do papel filtro e câmara de pressão, demonstrou que para ambas as técnicas, o modelo de Fredlund et al. (1994) ajustou-se melhor aos valores experimentais, sendo que o de Driessen (1986), apresentou os maiores erros. Disto se verifica que o primeiro modelo é o mais indicado para estes materiais.

A partir dos dados de sucção matricial e total obtidos através do método do Papel Filtro, verificou-se que os 5 materiais apresentam curvas típicas de materiais argilosos, mostrando grandes variações de sucção com as mudanças no teor de umidade. Para um mesmo valor de sucção verificou-se que o material 4 possui maior retenção que os demais, seguido dos materiais 2, 3, 1 e 5, sendo que na maioria dos casos a maior retenção foi proporcional ao teor da fração argila.

Para a sucção osmótica ocorreram, em todos os casos, acréscimos da mesma à medida que o material apresentou-se mais seco, mostrando comportamentos semelhantes aos observados por Tang et al. (2002). Relacionando os dados das sucções osmótica final e inicial com os da condutividade elétrica de cada material, observou-se boa correspondência apenas para materiais com elevados teores de umidade, situação em que foi possível sua medição. Os maiores valores de sucção osmótica foram observados para os materiais mais argilosos (materiais 2, 3 e 4).

Quando comparados os resultados das curvas de retenção (sucção total) pelos processos de umedecimento e secagem, a partir dos métodos do Dessecador de Vácuo e Papel Filtro respectivamente, se observa, como esperado, diferenças entre umidades para um mesmo valor de sucção. O maior teor de umidade para uma determinada sucção ocorre para o processo de secagem, isto é devido provavelmente ao fenômeno de histerese, que é mais acentuado nos materiais argilo-siltosos (materiais 1 ao 4) do que no material areno-silto-argiloso (material 5).

Quanto as Técnicas do Papel Filtro e Câmara de Pressão para a determinação da curva de retenção de água no solo, pode-se dizer que a primeira se apresentou como a 
mais adequada para os materiais analisados da Formação Guabirotuba, devido a sua versatilidade, rapidez e pela possibilidade da determinação de amplas faixas de sucções (inclusive muito elevadas). No entanto, alguns cuidados devem ser tomados, tais como, garantir contato firme entre a amostra e o papel (sucção matricial) e evitar mudanças de umidade durante a pesagem que são muito aceleradas nesse procedimento, comprometendo os resultados de sucção. Em relação a segunda técnica, neste caso, o tempo de equilíbrio para cada sucção foi extremamente demorado, e ainda ocorre limitação do equipamento para imposições de sucções acima de $10000 \mathrm{kPa}$, sendo que, para o presente trabalho foi necessária uma faixa de sucção superior a esta.

Os ensaios de curva de retenção realizados a partir da Técnica do Dessecador de Vácuo (Sucção total), mostraram-se adequados, apresentando valores muito próximos, aos obtidos para as amostras ensaiadas, mostrando a eficiência do método para a avaliação dos teores de umidade de equilíbrio. Também se mostrou adequado para imposição de sucções muito altas e requeridas neste trabalho.

\subsection{Quanto às características de expansão}

\subsubsection{Influência da mineralogia}

As correlações entre o índice mineralógico proposto neste trabalho (IM) e as pressões de expansão indicaram que existe acentuada influência deste índice na previsão da expansão dos materiais quando a sucção é baixa, no entanto, quando a sucção cresce a previsibilidade do potencial expansivo a partir do índice mineralógico diminui, provavelmente, devido à maior influência de outros fatores (plasticidade, $\rho d$, etc.) que também são determinantes no processo expansivo destes materiais. Este aspecto demonstra de maneira inequívoca, a importância da sucção no comportamento à expansão desses materiais. 


\subsubsection{Influência da textura/estrutura}

As imagens obtidas através da Microscopia Eletrônica de Varredura, permitiram observar a textura predominantemente argilosa dos materiais da Formação Guabirotuba, além da orientação dos minerais, que em alguns casos, não apresentam orientação preferencial (Material 1), por vezes é medianamente orientada (Material 4) e em outros casos apresenta uma textura bem orientada (Material 2), além da ocorrência de vazios entre as placas dos argilominerais e das trincas geradas nos materiais devido ao processo de secagem, o que deve favorecer o processo expansivo, quando os mesmos são submetido a variações de umidade. De uma maneira geral, observou-se que os materiais com textura mais orientada apresentaram maiores pressões de expansão.

\subsubsection{Influência da sucção}

Os resultados de pressões de expansão, quando confrontados com os dados de sucções, mostraram de forma clara, a grande influência da sucção no potencial expansivo dos materiais. Ou seja, para um mesmo material, quanto maior a sucção, maior a pressão de expansão.

Para um mesmo teor de umidade, os materiais estudados apresentam diferentes valores de sucção, devido entre outros fatores, à geometria dos poros, granulometria e mineralogia da fração fina o que condiciona também resultados diferentes de pressão de expansão.

Deve-se também levar em consideração que os resultados de pressão de expansão foram em geral muito altos para os materiais com baixos teores de umidade. Acredita-se que além dos efeitos capilares provenientes da sucção inicial do solo este comportamento deva-se às condições em que o ensaio é conduzido, ou seja, a amostra é confinada lateralmente (deformação unidimensional) e adicionalmente, a inundação foi realizada com água destilada, livre de sais o que pode influenciar na sorção da água pelo material argiloso, visto que, esta seria mais significativa pela diferença de concentração de íons entre a solução do solo e a água adicionada o que é um comportamento típico de materiais argilosos.

Embora os resultados aqui mostrados sejam provenientes de ensaios laboratoriais, para fins práticos, eles indicam em hipótese que os materiais desta Formação podem apresentar pressões de expansão pelo umedecimento intempestivo dos mesmos por 
diversos fatores (pluviosidade, ação antrópica, etc), caso fiquem expostos (excavações, desmoronamentos, etc) até atingirem sucções acima dos $1000 \mathrm{kPa}$ aproximadamente, na maioria dos materiais estudados.

\subsubsection{Influência do método de ensaio}

Os resultados obtidos na câmara edométrica com sucção imposta por umidade relativa (Esteban e Sáez, 1988), mostraram que não ocorre deformação do material, nem manifestação de pressão de expansão, apesar das amostras experimentarem acréscimos de umidade, necessários para reduzir a sucção desde 39423,0 kPa até 990,9 kPa (Tabela 54).

Em contrapartida, no edômetro convencional houve significativa manifestação da expansibilidade das amostras quando os ensaios foram conduzidos em amostras com sucções iniciais de 39627,0 a 993,92 kPa e que foram reduzidas até próximas a zero após a inundação (umidades próximas à saturação).

A diferença dos ensaios realizados nos edômetros convencional e por imposição de umidade relativa é a velocidade de entrada da água na amostra, sendo que no primeiro caso o umedecimento é dado pela fase líquida, na qual a amostra é inundada intempestivamente, enquanto no segundo caso, o umedecimento é lento, pelo equilíbrio da sucção ser dado pela fase de vapor. Este fato também foi observado no edômetro de translação de eixos que apesar do umedecimento ser pela fase líquida, a velocidade do fluxo de água para as amostras estava condicionada pela permeabilidade da placa porosa de 15 bar que é muito baixa.

\subsection{Quanto à tensão de pré-adensamento}

Apesar de não terem sido determinadas as pressões de pré-adensamento para todas as amostras nas quais foram realizados os ensaios de pressão de expansão e de não ter sido possível caracterizar de forma satisfatória o trecho da "reta virgem", foram estimadas as tensões de pré-adensamento dos materiais estudados, os quais apresentaram valores entre 150 e $1380 \mathrm{kPa}$. Estes valores mostraram-se compatíveis com os já determinados por outros pesquisadores. 
Estes valores de tensões de pré-adensamento muito elevados, mostram claramente que existe uma sobreadensamento das amostras, o que implica uma maior prédisposição à expansão destes materiais em relação a materiais normalmente adensados.

Também se observou, acréscimos das tensões de pré-adensamento com os valores de sucção impostos às amostras antes dos ensaios de pressão de expansão, o que estaria relacionado com a histerese relativa ao material pelo processo de umedecimento, e que provavelmente é maior com o aumento da sucção inicial da amostra.

\section{SUGESTÕES PARA FUTUROS TRABALHOS}

No desenvolvimento desta pesquisa foram levantadas uma série de questões que podem ser objetos de estudos futuros. Entre elas podem-se destacar:

- Ensaiar outros materiais expansivos para verificar a inexistência de pressão de expansão quando utilizada a câmara edométrica baseada na técnica de imposição de umidade relativa;

- Devido ao aspecto acima citado, ainda se sugere a realização de ensaios de pressão de expansão com equipamentos que permitam um controle da velocidade de entrada de água nas amostras;

- Avaliar as modificações geradas na microestrutura dos materiais estudados devido à variação nos teores de umidade (desde natural até seca ao ar). Para este propósito deverá ser utilizado um Microscópio Eletrônico de Varredura que permita estas observações, sem que o teor de umidade seja significativamente alterado nas amostras;

- Complementar os estudos aqui realizados com outros materiais expansivos da Formação Guabirotuba não contemplados neste trabalho, visando uma melhor caracterização, bem como, o melhoramento dos índices IM e ICM propostos neste estudo, que fornecerão subsídios para a previsão da pressão de expansão desses materiais na região Metropolitana de Curitiba. 


\section{CAPÍTULO 7. REFERÊNCIAS BIBLIOGRÁFICAS}

AITCHISON, G. D. (1961). Relationships of moisture stress and effective stress functions on unsaturated soils. Pore pressure and Suction in Soils, Butterworths, London.

AITCHISON, G. D. (1965). Moisture equilibra and moisture changes in soils beneath covered areas. A Symp. in Print, Aitchison, G. D., Ed. Austrália: Butterworths, p. 1965, 278.

AITCHISON, G. D.; RUSSAM, K. \& RICHARDS, B. G. (1965). Engineering concepts of moisture equilibra and moisture equilibra and moisture changes in soils beneath covered areas. Butterwotths, Sidney, Proceedings..., p. $7-21$.

AITCHISON, G. D. (1967). The separate roles of site investigation, quantification of soil properties and selection of operational environment in the determination of foundation design on expansive clay. $3^{\text {rd }}$ Asian Conf. Soil Mechanics Found., Eng., Haifa.

AITCHISON, G. D. \& MARTIN, R. (1973). The quantitative description of the stress deformation behavior of expansive soils. - Preface to set of papers, In: Proc. $3^{\text {rd }}$ International Conference on Expansive Soils, Haifa- Israel, Vol.2, p.79-82.

AITCHISON, G. D. \& MARTIN, R. (1973). The quantitative description of the stress deformation behavior of expansive soils. 2. A membrane oedometer for complex stress - path studies in expansive clays. Preface to set of papers, In: Proc. $3^{\text {rd }}$ International Conference on Expansive Soils, Haifa- Israel, Vol.2, p. 83 -88.

ALONSO, E. E. \& LLORET, A. (1985). Comportamiento de suelos parcialmente saturados. Revista de Obras Públicas, p. 435 - 461. 
ASSOCIAÇÃO BRASILEIRA DE NORMAS TÉCNICAS (1980). MB-30 NBR 6459: SoloDeterminação do limite de liquidez.

ASSOCIAÇÃO BRASILEIRA DE NORMAS TÉCNICAS (1982). MB-31 NBR 9180: SoloDeterminação do limite de plasticidade.

ASSOCIAÇÃO BRASILEIRA DE NORMAS TÉCNICAS (1984). MB-28 NBR 6508: Determinação da massa Específica.

ASSOCIAÇÃO BRASILEIRA DE NORMAS TÉCNICAS (1984). MB-32 NBR 7181: SoloAnálise Granulométrica.

ASTM (1991). Standard practice for Maintaining Constant Relative Humidity by Means of Aqueous Solutions (E-104-85). Annual Book of ASTM Standards, Philadelphia, P. A; ASTM.

ASTM (1993). Standard test method for measurement of soil potential (suction) using filter paper (D5298) 1993 Annual Book of ASTM Standards, 04.08 (4), Philadelphia, P. A; ASTM.

BADILlo, E. J. \& RODRIGUEZ, A. R. (1988). "Mecánica de suelos”. Tomo III, Flujo de agua en suelos. México, Editorial Limusa. 188. Cáp. 1 - 2.

BARDEN, L. (1965). Consolidation of compacted and unsaturated clays. Géotechnique, 15(3). p. 267-286.

BARROW, G. M. (1961). Physical - Chemistry. New York, McGraw - Hill.

BAVER, L. D. \& GARDNER, W. H. (1972). Soil Physics. $4^{\circ}$ edição, London, Wiley \& Sons, Inc., 1972.

BECKER, R. D. (1982). Distribuição dos sedimentos cenozóicos na região metropolitana de Curitiba e sua relação com a estrutura geológica e morfológica regional. Dissertação (Mestrado em Geociências), Universidade Federal do Rio Grande do Sul, Porto Alegre, 237p.

BIAREZ, J.; FLEUREAU, J. M.; ZERHOUNI, M. I. \& SOEPANDJI, B. S. (1987). Variations de volume des sois argileux lors de cycles de drainage-himidification. Revue Française de Geotechnique. Vol. 40, $4^{\circ}$ trim. p. $63-71$. 
BIGARELLA, J. J. \& SALAMUNI, R. (1962). Caracteres texturais dos sedimentos da Bacia de Curitiba. Boletim da Universidade Federal do Paraná. Instituto de Geologia. n 7, 164p.

BISHOP, A.W. (1959). The principle of effective stress. Tecknisk Ukebland 106(39), p. 859863.

BISHOP, A. W. \& DONALD, I. B. (1961). The experimental study of partly saturated soil in the triaxial apparatus. In: Proceedings on $5^{\text {th }}$ International Conf. Soil Mechanics Foundation Engineering (Paris), 1, p. 13-22.

BISHOP, A. W. \& BLIGHT, G. E. (1963). Some aspects of effective stress in saturated and partly saturated soils. Géotechnique, Vol.13, Nº 3, p. 177-198.

BLIGHT, G. E. (1967). Effective stress evaluation of unsaturated soils. Proceedings of the American Society of Civil Engineers, Vol. 93.

BOCKING, K. A. \& FREDLUND, D. G. (1980). "Limitation of the axis translation technique”. In: International Conference on expansive Soils, 4, Denver, 1980. Proceedings..., p. 117 - 135.

BRADY, N. C. (1989). Natureza e propriedades dos solos. Rio de Janeiro, Freitas Bastos, $7^{\circ}$ ed., 898 p.

BREKKE, T. L. (1965). On the Measurement of the Relative Potential Swellability of Hydrothermal Montmorillonite Clay from Joints and Faults in Pre-Cambrian and Paleozoic Rocks in Norway. International Journal of Rock Mechanics and Mining Science. Vol. 2, p. 155165, Great Britain.

BUCKEY, E. L. (1974). Loss and damage on residential slab-on-ground foundations. Construction Research Center, Dept. Civil Eng., Univ. Texas Arlington, Rep. TR-2-74, 23p.

BUENO, B. S. \& VILAR, O. M. (1995). Mecânica dos Solos. Departamento de Geotecnia EESC - USP, São Carlos, Vol. 1, Publicação 095/95, Reimpressão. 131p.

CAMARGO, O. A. et al. (1986). Métodos de Análise Química, Mineralógica e Física de Solos do Instituto Agronômico de Campinas. Boletim Técnico do Inst. Agron., $\mathrm{n}^{\circ} 106,94 \mathrm{p}$. 
CAMPOS, J. O. (1989). A desagregabilidade dos siltitos da Formação Corumbataí Conseqüências práticas, fenomenologia provável e experimentação pertinente. Rio Claro. 120p. Concurso Público para Livre Docência, Universidade Estadual Paulista - Campus de Rio Claro São Paulo.

CARCEDO, F. J. A.; GIJON, M. F.; MAZO, C. O.; RODRIGUEZ, J. L. S. (1986). Mapa previsor de riesgos por expansividad de arcillas en España a escala 1:1.000.000. Série: Geologia Ambiental. Instituto Geológico y Minero de Espana. Madrid. 64p.

CARVAlHO, J. B. Q., de (1997). Fundamentos da Mecânica dos Solos. $1^{\circ}$ ed., Campina Grande - Paraíba, Ed. Marcone. 310 p.

CHANDLER, R. J. \& GUTIERREZ, C. I. (1986). The filter paper method of suction measurement. Géotechnique, 36, p. 265-268.

CHANDlER, R. J.; CRILly, M. S. \& MONTGOMERY - SMITH, G. (1992). A low cost method of assessing clay desiccation for low-rise buildings. Proc. of the Institute of Civil Engineering., 92, p. 82-89.

CHEN, F. H. (1965). The use of piers to prevent the uplifting of lightly loaded structures founded on expansive soil. Proc. Eng. Effects of Moistures Changes in Soils, Int. Res. Eng. Conf. Expansive Clay Soils. Supplementing the Symposium in Print, Texas, A \& M Press., p. 152-171.

CHEN, F. H. (1975). Foundation on expansive soils. Developments in Geotechnical Engineering, Amsterdam, Elsevier, 12:280.

CHENGGANG, B. et al. (1998). Properties of unsaturated soils and slope stability of expansive soil. Proceedings of the Second International Conference on Unsaturated Soils, Vol. 2, p. 71, China.

COSTA NUNES, A. J. da (1978). Fundações em terrenos expansivos. $1^{\circ}$ Seminário Regional de Mecânica dos Solos e Engenharia de Fundações. Salvador, maio 1978, p. 161 - 190.

COSTA NUNES, A. J. da (1978). Terrenos compressiveis após inchamento. In Simpósio Nacional de Grandes Barragens, 12, São Paulo. Anais... São Paulo, Tema II. 
COULTHARD, J. M. \& BELL, F. G. (1993). The influence of weathering on the engineering behavior of Lower Lias Clay. The Engineering Geology of Weak Rock, Cripps et al. (ed), Balkema, Rotterdam, p. $183-192$.

CRONEY, D.; COLEMAN, J. D. \& BLACK, W. P. M. (1958). Studies of the movement and distribution of water in soil in relation to highway design and performance. Highway Research Board, Special Report 40, Washington D.C., p. 226 - 252.

CRONEY, D. \& COLEMAN, J. D. (1960). Pore pressure and suction in soil. Conference on Pore Pressure and Suction in Soils. London, Proceedings..., p. $31-37$.

CUI, Y. J. \& DELAGE, P. (1996). Yielding and plastic behavior of an unsaturated compacted silt. Géotechnique 46(2), p. 291-311.

DAVIDSON, J. M; NIELSEN, D. R. \& BIGGAR, J. W. (1966). The dependency of soil water uptake and release upon the applied pressure increment. Soil Sci. Soc. Am. Proceedings., 30(3), p. 298-394.

DEER, W. A.; HOWIE, R. A; ZUSSMAN, J. (1966). Minerais constituintes das rocha - Uma Introdução. Lisboa, Fundação Calouste Gulbenkian, 558 p.

DE LAMBAlLERIE, G. N. (1962). Contribuition a l'étude des phénomènes de gonflement accompagnata l'hidration des argiles compactes. Toulouse. 140p. (apud FRAZÃO, 1981).

DELAGE, P.; SURAJ DE SILVA, G. P. R.; DE LAURE, E. (1987). Un nouvel appareil triaxial pour les soils non saturés. In: Proceedings of the $9^{\text {th }}$ European Conference on Soil Mechanics and Foundation Engineering, Vol. I, p. 26-28, Balkema, Dublin.

DELAGE, P.; SURAJ DE SILVA, G. P. R.; VICOL, T. (1992). Suction controlled testing of non saturated soils with an osmotic consolidometer. In: Proceedings $7^{\text {th }}$ International Conference on Expansive Soils. Dallas, p. 206-211.

DELAGE, P.; HOWART, M. D; CUI, Y. J. (1997). The relationship between suction and swelling properties in a heavily compacted unsaturated clay, Engineering Geology, 50, p. 31 48. 
DINEEN, K. \& BURLAND, J. B. (1995). “A new approach to osmotically controlled oedometer testing". In: Proceedings of the First International Conference on Unsaturated Soils, UNSAT 95, Paris - França, V.2, p. 459 - 465.

DONALD, I. B. (1956). Shear strength measurement in unsaturated non cohesive soils with negative pore pressures. In: Proceedings $2^{\text {nd }}$ Australia- New Zealand Conf. Soil Mech. Found. Eng. Christchurch, New Zealand, p. $200-205$.

DOURADO NETO, D. et al. (2000). Software to model soil water retention curves (SWRC, version 2.00). Scientia Agricola Journal, Vol. 57, n. 1, Piracicaba, Janeiro/março, 2000.

DRIESSEN, P. M. (1986). Land use system analysis. Wageningen.

ESCARIO, V. (1967). Measurement of the swelling characteristics of a soil fed with water under tension. Int. Cooperative Res. On the Predictions of Moisture Contents under Road Paviments. O.C.D.E.

ESCARIO, V. (1969). Swelling of soils in contact with water at negative pressure. In: Proceedings of the $2^{\text {nd }}$ International Conference on Expansive Clay Soils, Texas, A. and M. University, p. 207-217.

ESCARIO, V. (1969). Determination of the geotechnical characteristics of expansive soils. Second International Research and Engineering Conference on Expansive Clay Soils. Texas. p. $114-120$.

ESCARIO, V. \& SAEZ, J. (1973). Measured of the properties of swelling and collapsing soils under controlled suction. In: Proc. ${ }^{\text {rd }}$ Int. Conf. Expansive Soils (Haifa). p. 195-200.

ESCARIO, V. (1989). Formulaciones para la definición de la resisténcia al esfuerzo cortante de los suelos parcialmente saturados. Bol. Soc. Española de Mecánica del Suelo, 92, p. 3-12.

ESTEBAN, F. \& SAEZ, J. (1988). A device to measure the swelling characteristics of rock samples whit control of the suction up to very high values. ISRM, Symposium on rock mechanics and power plants, (Madrid), Vol. 2.

FARREL, D. A. \& LARSON, W. E. (1972). Modeling the pore structure of porous media. Water Resources Research, v. 8, p. 699-706, 1972. 
FAWCETT, R. G. \& COLLIS-GEORGE, N. (1967). A filter-paper method for determining the moisture characteristics of soil, Australian Journal. Exp. Agriculture and Animal Husbandry, Vol.7, p.162-167.

FELIPE, R. S. (1998). A gestão de riscos geológicos urbanos, erosão e movimento gravitacional de massa na Formação Guabirotuba. GTU:PUC:UTC, 47p. Especialização em gestão de meio urbano, Curitiba, PR.

FELIPE, R. S. (1999). A erodibilidade da Formação Guabirotuba. Anais da Mesa Redonda Características Geotécnicas da Formação Guabirotuba. Curitiba, 21 de setembro de 1999. ABMS/UFPR, p. 53-63.

FONSECA, E. C. (1991). Ensaio de Cisalhamento Direto com sucção controlada em solos não saturados. Rio de Janeiro, PUC. 173p. (Dissertação de Mestrado).

FORTIN, P.; TRESCASES, J. J.; MELF, A. J.; SCHMITT, J. M. \& THIRY, M. (1989). Rare earth elements (REE) accumulations in the Curitiba Basin (Brazil). In: International Geochemical Exploration Symposium, 13, Rio de Janeiro, S. B. Gq, p. 66-68.

FRAZÃO, E. B.; GOULART, E. P. (1976). Aspectos da expansibilidade de argilo-minerais: Algumas Implicações em Obras Civis. In: $1^{\circ}$ Congresso Brasileiro de Geologia de Engenharia, ABGE, São Paulo, Tema 11, 2: 351-365.

FRAZÃO, E. B. (1981). Contribuição à metodologia para determinação da pressão de expansão em solos e rochas. São Paulo. 71p. Dissertação de Mestrado, Instituto de Geociências, Universidade de São Paulo - São Paulo.

FREDLUND, D. G. \& MORGENSTERN, N. R. (1976). Constitutive relations for volume change in unsaturated soils. Canadian Geot. J., 13(3), p. $261-276$.

FREDLUND, D. G. \& MORGENSTERN, N. R. (1977). Stress State Variables for Unsaturated Soils. Journal of Geot. Div. ASCE., Vol. 103 GT5, p. 447-466.

FREDLUND, D. G. et al. (1978). The Shear Strength of Unsaturated Soils. Canadian Geotechnical Journal, V. 15, p. $313-321$. 
FREDLUND, D. G. \& RAHARDJO, H. (1993). Soil mechanics for unsaturated soils. New York, John Wiley \& Sons, Inc.1993. p. 1 - 6.

FREDLUND, D. G.; XING, A. \& HUANG, S. (1994). Predicting the permeability functions for unsaturated soil using the soil-water characteristic curve. Canadian Geotechnical Journal, v. 31, n 4, p. 533 - 546, 1994.

FREDLUND, D. G. (2002). Use of soil-water characteristic curves in the implementation of unsaturated soil mechanics. Proceedings of the Third International Conference on Unsaturated Soils, UNSAT 2002, 10-13 march 2002, Recife, Brazil, Vol. 3, p. 887 - 901.

GARDNER, W. R. (1937). A method of measuring the capillary tension of soil moisture over a wide moisture range. Soil Science, Vol. 43, $\mathrm{N}^{\circ} 4$, january-june, p. 277-283.

GARDNER, W. R. (1956). Calculations of capillary conductivity from pressure plate outflow data. Proceedings of the Soil Science Society of America 20, p. 317-320.

GILLOTT, J. E. (1987). Clay in Engineering Geology. Elsevier Publ. Company, Amsterdam.

GOLDSTEIN, J.; NEWBURY, D. E.; ECHLIN, P; JOY, D. C.; ROMING Jr., A. D.; LYMAN, C. E.; FIORI, C. \& LIFSHIN, E. (1992). Scanning electron microscopy and X-Ray microanalysis. Plenun Press, New York, $2^{\text {nd }}$. Edition, 820p.

GOMES, C. F. (1986). Argilas. O Que São e para que Servem. Lisboa, Fundação Calouste Gulbenkian, $457 \mathrm{p}$.

GRAHAM BRYCE, I. J. (1967). Method of supplying water to soil at osmotically controlled potentials. Chem.Ind., p. 353-354.

GRIM, R. E. (1953). Clay mineralogy. McGraw-Hill Publ. Company Ltda, New York, 384p.

GRIM, R. E. (1962). Applied clay mineralogy. McGraw-Hill Publ. Company Ltda, New York.

HACH-HACH, A. (1998). Inventário das feições erosivas e dos movimentos de massa gravitacionais na região leste da grande Curitiba-Paraná - Escala 1:20.000. Dissertação de Mestrado, EESC - USP, São Carlos. 2v, 175p. 
HAMBLIN, A. P. (1981). "Filter paper method for routine measurement of field water potential ".Journal of Hidrology, 53, p. 355-360.

HAMILTON, J. J. (1969). Effects of environment on the performance of shallow foundations. Canadian Geotech. J. 6: $65-80$.

HARVEY, E. N.; BARNES D. K.; Mc ELROY A. H.; WHITELEY A. H.; PEASE D. C. \& COOPER, K. W. (1994). Bubble formation in animals, 1. Physical factors. Journal of Cellular and Comparative Physiology 24, $\mathrm{N}^{\circ} 1$.

HENKEL, D. J. (1960). The relationships between the effective stresses and water content in saturated clays. Géotechnique, Vol.10, $\mathrm{N}^{\mathrm{o}} 2$.

HILF, J. W. (1956). An investigation of pore-water pressure in compacted cohesive soils. Denver, 1956. 109 p. (Doutorado - Faculty of the Graduate Scholl of the University of Colorado).

HILLEL, D. (1971). Soil water - Physical principles and processes. New York, Academic Press, 1971. cap. 1 - 5.

HILLEL, D. (1980). Fundamental of soil physics. Academic Press, New York, p. 413.

HO, Y. F \& FREDLUND, D. G. (1982). A Multistage Triaxial Test for Unsaturated Soils. Geotechnical Testing Journal, GTJODJ. Vol.5, No 1/2, p.18-25.

HOLLAND, J. E. \& LAWRENCE, C. E. (1980). Seasonal heave of Australian clay soil. Proc. $4^{\text {th }}$ Int. Conf. Expansive Soils, Denver, CO 1:302-321.

HOLTZ, W. G. \& GIBBS, H. J. (1956). Engineering properties of expansive clays. Transact. ASCE, 121, p. 641-677.

HOLTZ, W. G. (1959). Expansive Clays-properties and problems. Quart. Colorado School Mines 54(4):89-117.

HOLTZ, W. G. (1983). The influence of vegetation on the swelling and shrinking of clays in the United States of América. Geotechnique, 33, 159-163. 
HORTA DA SILVA, J. A. (1975). Solos expansivos - Comportamento, identificação, quantificação da instabilidade volumétrica e projetos de fundações (Parte I). Geotecnia, n 13, p. $29-63$.

HORTA DA SILVA, J. A. (1975). Solos expansivos - Comportamento, identificação, quantificação da instabilidade volumétrica e projetos de fundações (Parte II). Geotecnia, ${ }^{\circ}{ }^{14}$, p. $5-18$.

IGNATIUS, S. G. \& FRAZÃO, E. B. (1990). Estudo comparativo de metodologias para determinação de pressão de expansão em solos e rochas. In: $6^{\circ}$ Congresso Brasileiro de Geologia de Engenharia e IX Congresso Brasileiro de Mecânica de Solos e Fundações. ABGE. Salvador - 4 - 9 de novembro 1990, v. 2, p. 155 - 158.

I.S.R.M. - INTER. SOC. FOR ROCH MECH. (1972). Suggested methods for determining water content, porosity, density, absorption and related properties and swelling and slake-durability index properties. Document n ${ }^{\circ}$ 2, Final Draft, Lisbon, Portugal. p. 142 - 156.

I.S.R.M. - INTER. SOC. FOR ROCH MECH. (1989). Commission on swelling rock and working group on swelling rock of the commission on testing methods. Suggested methods for laboratory testing of argillaceous swelling rocks. Int. J. Rock Mech. Min. Sci. \& Geomech. Abstr. Vol. 26. $\mathrm{N}^{\mathrm{0}}$ 5, p. 415-426.

IWATA, S; TABUCHI, T. \& WARKENTIN, B. P. (1988). Soil-water interactions. Mechanisms and Applications. Ed. Marcel Dekker, New York. 380 p.

JENNINGS, J. E. B. (1961). A revised effective stress law for use in the prediction of the behavior of unsaturated soils. Pore Pressure and Suction in Soils. Butterworths, London, p. 26 30.

JENNINGS, J. E. B. \& BURLAND, J. B. (1962). Limitations to the use of effective stresses in partly saturated soils. Géotechnique, vol. 12, Nº4, (SM5), p. 125 - 144.

JENNINGS, J. E. (1973). The Engineering significance of construction on dry subsoils. Proceedings of the Third International Conference on Expansive Soils, Haifa, Vol. II, p. 27 32. 
JEREMIAS, F. T. S. A. A. (1991). Importância da expansibilidade na durabilidade dos materiais rochosos e técnicas laboratoriais para a sua avaliação. Lisboa. Dissertação de Mestrado - Laboratório Nacional de Engenharia Civil, Universidade Nova de Lisboa. 222p.

JIMENES, S. J. (1993). "Hacia una Mecánica de Suelos no Saturada”, Revista Ingeniería Civil Vol.88 $-1^{\circ}$ parte, p. $145-164$.

JIMENES, S. J. (1993). "Hacia una Mecánica de Suelos no Saturada". Revista Ingeniería Civil Vol.90 - $2^{\circ}$ parte, p. $77-92$.

JUCÁ, J. F. T. (1993). Comportamiento de los suelos parcialmente saturados bajo succión controlada. Madrid, 1990, 346 p. Doctorado, Universidad politécnica de Madrid, España.

KASSIF, G. \& BEN SHALOM, A. (1970). Apparatus for measuring swell potential under controlled moisture intake. ASTM Journal of Materials, 5(4), p. 261-276.

KASSIF, G. \& BEN SHALOM, A. (1971). Experimental relationship between swell pressure and suction. Géotechnique 21(3), p. 245-255.

KASSIF, G. et al. (1973). Swell - pressure relationship at constant suction changes. Third International Conference on Expansive Soils, Haifa, Proceedings..., V. 1, p. 201 - 208.

KOMORNIK, A.; LIVNEH, M. \& SMUCHA, S. (1980). Shear strength and swelling of clays under suction. Proceedings of the $4^{\text {th }}$ Int. Conf. on Expansive Soils, Denver, Colorado, p. 206226.

KORMANN, A. C. M. (2002). Comportamento Geomecânico da Formação Guabirotuba: Estudos de Campo e Laboratório. Tese (Doutorado), Escola Politécnica, USP, São Paulo, 429p.

LAGERWERF, J. V.; OGATA, G.; EAGLE, H. E. (1961). Control of osmotic pressure of culture solutions with polyethylene glycol. Science 133, p. 1486-1487.

LAMBE, T. W. (1960). A mechanistic picture of shear strength in clay. Research Conf. On Shear Strength of Coehesive Soils, Boulder, Colorado, p 555-580.

LANG, A. R. G. (1967). Osmotic coefficient and water potentials of sodium chloride solutions from 0 to $40{ }^{\circ} \mathrm{C}$. Australian Journal of Chemistry, 20, p. 2017-2023. 
LAUTRIN, D. (1989). Utilisation pratique des parameters derives de l'essai au bleu de méthylène dans les projets de génie civil. Bull. Lab. P. et. Ch., fevr. - mars., p. 53-65.

LE ROUX, A. (1976). Classification des différentes textures de roches argileuses et marneuses en relation avec leur comportement. Bull. Liaison Labo. P. et Ch., spécial, décembre 1976. p. $39-48$.

LIBARDI, P. L.; REICHARDT, K.; NASCIMENTO FILHO, V. F. (1979). Análise da redistribuição da água visando a condutividade hidráulica do solo. Energia Nuclear \& Agricultura, v. 1, p. 108-122, 1979.

LIBARDI, P. L. (1995). Dinâmica da Água no Solo. Edição do Autor, ESALQ, Depto. de Física e Metereologia, Piracicaba, 497 p.

LOW, P. E. \& ANDERSON, D. M. (1958). Osmotic pressure equations determining thermodynamic properties of soil, Soil Science, Vol.I, 86, p. 251-253.

LUMB, P. (1968). Statistical aspects of field measurements. Proceedings of the $4^{\text {th }}$ Conference of the Australian Road Research Board, Melbourne, Vol.4, p. 1761-1771.

MACHADO, S. L. (1998). Aplicação de conceitos de elastoplasticidade a solos não saturados. Tese (Doutorado), EESC - USP, São Carlos, 1998. 360 p.

Mc QUEEN, I. S. \& MILLER, R. F. (1968). Calibration and evaluation of wide-range gravimetric method for measuring soil moisture stress. Soil Science 10, p. 521 - 527.

MADLUN, I. (1983). Características e métodos de identificação de solos expansivos. (Relatório de Monitoria), Departamento de Geotecnia, EESC-USP, São Carlos.

MARINHO, F. A. M. (1994). Medição de sucção com o método do papel de filtro. Anais... X COBRAMSEF, v. 2, p. 515 - 522.

MARINHO, F. A. M. (1995). A Técnica do Papel Filtro para Medição de Sucção. Encontro sobre Solos não Saturados - Rio Grande do Sul - 18 a 20 de outubro de 1995, p. 112 - 125.

MARSHALL, T. J. \& HOLMES, J. W. (1981). Soil physics. Cambridge, Cambridge University Press, 1981. Cap. 1 - 4. 
MATYAS, E. L. (1966). Air and water permeability of compacted soils. Permeability and Capillarity of Soils, American Society for Testing and Materials, Special Technical Publication, No417, Philadelphia, Pa., USA.

MATYAS, E. L. \& RADHAKRISHNA, H. S. (1968). Volume change characteristics of partially saturated soil. Géotechnique 18 (4), p. 432 - 448.

MAZO, C. O.; AUÑON, J. S. \& ESTEBAN, F. (1996). Laboratory tests and equipment with suction control. Proceedings of the First International Conference on Unsaturated Soils/ UNSAT'95/Paris/ France/6-8 setembro de 1995, Vol. 3, p. 1509-1515.

MINEROPAR - SERVIÇO GEOLÓGICO E PESQUISA MINERAL (1994). Mapeamento geológico - geotécnico na região do Alto Iguaçu. Curitiba - outubro, 1994.

MITCHELL, J. K. (1976). Fundamentals of soil behavior. Ed. John Wiley \& Sons, Inc. New York, p. 442.

MITCHELL, J. K. (1993). Fundamentals of soil behavior. 2nd ed., Ed. John Wiley \& Sons, Inc. U.S.A. 437 p.

MOORE, D. M. \& REYNOLDS JR., R. C. (1989). X-Ray Diffraction and the Identification and Analysis of Clay Minerals. Oxford University Press, 332p.

NELSON, J.D. \& MILLER, D.J. (1992). Expansive soils- Problems and practice in foundation and pavement engineering. John Wiley \& Sons, Inc., p. 259.

NOGUEIRA, J. B. (1988). Mecânica dos Solos. São Carlos. EESC - USP. Publicação 042/94. Reimpressão. 197 p.

NOGUEIRA, J. B. (1998). Mecânica dos Solos. Ensaios de laboratório. São Carlos. EESC USP. Reimpressão. 248 p.

OLPHEN, H. V. (1963). An introduction to clay colloid chemistry. Willey Interscience, New York, 301p. 
OLSON, R. E. \& LANGFELDER, L. J. (1965). Pore water pressures in unsaturated soils. Journal of the Soil Mechanics and Foundation Division. Proceedings of the American Society of Civil Engineers, New York, v. 91(Sm4), p. 127 - 150, July 1965.

OLSON, R. E. \& DANIEL, D. E. (1981). Measurement of the Hydraulic Conductivity of Fine Grained Soils, Permeability and Groundwater Contaminant Transport. ASTM STP 746, T. F. Zimmie and C. O. Riggs, Eds., p. 18 - 64.

PACHECO SILVA, F. (1970). Uma nova construção gráfica para a determinação da pressão de pré-adensamento de uma amostra de solo. COBRAMSEF, Rio de Janeiro, Vol. II, Tomo I, p. 219-224.

PECK, A. J. \& RABBIDGE, R. M. (1966). Soil Water potential: Direct measurement by a new technique. Science, New York, 151, p. 1385-1386.

PEJON, O. J. (1992). “Mapeamento geotécnico regional da folha de Piracicaba (SP): Estudos de Aspectos Metodológicos de Caracterização e Apresentação de Atributos. Tese de Doutorado. EESC - USP. São Carlos, 224p.

PEJON, O. J. (1995). Étude du gonflement de roches sédimentaires argilo- calcaries en présence d'eau. Observation au Microscope Életronique à Balayage. Travail réalise à la section de Géologie et Materiaux naturels de la Division de Mécanique de Sols et Géologe de l'Ingénieur du Laboratoire Central de Ponts et Chaussées. Paris. 87 p.

PEJON, O. J. \& ZUQUETTE, L. V. (1996). Estudo dos fenômenos associados a expansão de rochas sedimentares de granulometria fina. Rio de Janeiro. p. 151 - 159. $8^{\circ}$ Congresso Brasileiro de Geologia de Engenharia, vol.1, set.1996.

PEJON, O. J.; LE ROUX, A.; GUIGNARD, D. (1997). Comportament à léau de roches argilomarneuses-suivi du gonflement, importante de la minéralogie et des texturas. Bulletin of the International Association of Engineering Geology, 55.

PEJON, O. J. (2000). Estudo dos Fenômenos de Expansão de Rochas Sedimentares de Granulometria Fina. Identificação, Caracterização e Mapeamento. Livre Docência. EESC USP. São Carlos, 201p. 
PEREIRA, E. M. \& PEJON, O. J. (1999). "Estudo do Potencial Expansivo dos Materiais Argilosos da Formação Guabirotuba na Região do Alto Iguaçu-PR". Anais da Mesa Redonda Características Geotécnicas da Formação Guabirotuba. Curitiba, 21 de setembro de 1999. ABMS/UFPR, p. 17-28.

PEREIRA, E. M. \& PEJON, O. J. (1999). Estudo do Potencial Expansivo dos Sedimentos Argilosos da Formação Guabirotuba na Região do Alto Iguaçu-PR. $9^{\circ}$ Congresso Brasileiro de Geologia de Engenharia. São Pedro, 07 a 10 de novembro de 1999. ABGE, publicação em CD16 páginas.

PEREIRA, E. M. (1999). Estudo do potencial expansivo dos materiais argilosos da Formação Guabirotuba na região do Alto Iguaçu - PR. Escola de Engenharia de São Carlos, Universidade de São Paulo, 106p. (Dissertação de Mestrado).

PHILIPPONNAT, G. (1991). Retrait - gonflement des argiles, proposition de méthodologie. Rev. Franç. Géotech., n 57, p. 5 - 22 (octobre, 1991).

POINTER, L. I. (1966). Method of subjecting growing plants to a continuous soil moisture stress. Agron. Journal, 58, p. 459-460.

PRESA, E. P. (1984). Deformabilidad de las arcillas expansivas bajo succión controlada. Centro de Estudios y Experimentación de Obras Públicas. Madrid. 274p.

PRESA, E. P; LINS, H. P; PRADO DE CAMPOS, L. E.; IGNATIUS, S.G.; CARVALHO, J. C. \& DIAS, R. D. (1988). Ensaios de Laboratório em Solos Parcialmente Saturados. In: Simpósio sobre Novos Conceitos em Ensaios de Campo e de Laboratório em Geotecnia, Rio de Janeiro, 25 - 27 de maio, p. 251-278.

REICHARDT, K. (1985). Processos de Transferência no sistema solo - planta - atmosfera. Fund. Cargill, Campinas, 466p.

RICHARDS, L. A. (1928). The usefulness of capillary potential to soil-moisture and plant investigators. Journal of the Agricultural Research. Washington, 37 (12).

RICHARDS, L. A. (1940). A pressure membrane extraction apparatus for soil suction. Soil science 51, p. 377-386. 
RICHARDS, B. G. (1966). The significance of moisture flow and equilibra in unsaturated soils in relation to the design of engineering structures built on shallow foundations in Australia. Symp. on Permeability and Capillarity of Soils, ASTM STP 417, Atlantic City.

RICHARDS, B. G. (1974). Behavior of unsaturated soils. Ed. I. K. Lee. Soil Mechanics. New York, American Elsevier Publishing Company, Inc., 1974. Cap. 4, p. 112 - 157.

RIDLEY, A. M. \& BURLAND, J. B. (1993). A new instrument for the measurement of soil moisture suction. Géotechnique 43. N 2 2. p. 321 - 334.

RIDLEY, A. M. \& BURLAND, J. B. (1995). A pore pressure probe for in situ measurement of soil moisture suction. Proc. Int. Conf. Advances in Site Investigation Practice I.C.E. London.

RIDLEY, A. M. \& BURLAND, J. B. (1995). Measurement of suction in materials with swell. Applied Mechanics Reviews, Vol. 48, N 9.

RIDLEY, A. M. \& WRAY, W. K. (1996). Suction measurement: “A review of current theory and practices". In: Proceedings of the First International Conference on Unsaturated Soils, UNSAT 95, Paris - França, Vol.3, p. 1293-1322.

SAlAMUNI, E. (1998). Tectônica da Bacia Sedimentar de Curitiba (PR). Tese (Doutorado), Instituto de Geociências e Ciências Exatas - UNESP, Rio Claro - São Paulo, vol. único, 214p.

SALAMINI, E. \& SALAMUNI, R. (1999). Contexto geológico da Formação Guabirotuba, Bacia de Curitiba. In: Mesa Redonda Características Geotécnicas da Formação Guabirotuba, Curitiba, 1999. Anais. Curitiba: ABMS/UFPR, 1999, p. 7-15.

SANTOS, P. S. (1989). Ciência e tecnologia de argilas. $2^{\circ}$. ed. São Paulo, Edgard Blücher. v1. $408 \mathrm{p}$.

SANTOS, P. S. (1992). Ciência e tecnologia de argilas. $2^{\circ}$. ed. Revisada e ampliada, São Paulo, Edit. Edgard Blücher Ltda. Vol.3.

SANTOS, C. R. \& VILAR, O. M. (1999/2000). Curva de Retenção de Água-Ajuste Matemático - SWCC - 1.0. USP, EESC, Dep. de Geotecnia, São Carlos - SP. 
SÃO MATEUS, M. S. C. (1994). Determinação em Laboratório da Condutividade Hidráulica de Solos não saturados. Dissertação de Mestrado, EESC - USP.

SEED, H. B.; WOODWARD, R. J.; Jr., \& LUNDGREN, R. (1962). Prediction of swelling potential for compacted clays. Journal Soil. Mech. Found. Div., Am. Soc. Civil Eng., 88, SM3, p. $53-87$.

SEEDSMAN, R. W. (1993). Comprehensive rock engineering. Characterizing Clay Shales. vol 3, cap. 7. Austrália, John A. Hudson. p. 151 - 164.

SIMMONS, C. S.; NIELSEN, D. R.; BIGGAR, J.W. (1979). Scaling of field-measured soil water properties. Hilgardia, v.47, p. 77-173, 1979.

SIMÕES, P. R. M. (1987). Aspectos relevantes sobre a implantação de obras de engenharia em solos e rochas expansivas. Centro de Pesquisa e Desenvolvimento - Informe Técnico, n 26 , junho de 1987. Camaçari - BA.

SKEMPTON, A. W. (1953). The colloidal activity of clays. Proc. $3^{\text {rd }}$ Int. Conf. Soil. Mech. Found. Eng., Switzerland. Vol.1, p. 57 - 61.

SNETHEN, D. R.; JOHNSON, L. D. \& PATRICK, D. M. (1977). An evaluation of expedient metodology for identification of potentially expansive soils. Federal Highway Administration, Washington, FHWARD., p. 77 - 94,.

SPIEGEL, M. R. (1969). Estatística. Ao Livro Técnico S.A. Rio de Janeiro, $2^{\circ}$ Ed., 580p.

TABOR, D. (1979). Gases, liquids and solids. Cambridge University Press.

TAYLOR, R. K. \& SMITH, J. 1986. The Engineering Geology of clay mineral: swelling, shrinking and mudrock breakdown. Clay Minerals, 21, p. 235 - 260.

TRAN NGOC LAN (1977). Un nouvel essai d'identification des sols: l'essai au bleu de méthyléne. Bull. Liaison Lab. P. et Ch., 88, mars - avril, p. 136 - 137.

VAN GENUCHTEN, M. T. (1980). A closed-form equation for predicting the hydraulic conductivity of unsaturated soils. Soil Sci. Soc.Am.J., vol. 44, n 5, p. 892 - 898. 
VELDE, B. (1992). Introduction to clay minerals. Chemistry, origins, uses and environmental significance. Chapmen Hall, London. 198 p.

VILAR, O. M. (1994). Deformações volumétricas induzidas por redução de sucção em um solo compactado. Anais do $2^{\circ}$ Simpósio sobre Solos Não Saturados, Recife-PE, 04-05 de abril de 1994, p. 191-196.

VILAR, O. M. et al. (1995). Ensaios de Campo e de laboratório em Solos não Saturados. Anais Encontro sobre Solos não Saturados, UFRGS, Porto Alegre.

VILAR, O. M. (1997). Introdução à mecânica de solos não saturados. Notas de aula.

VILAR, O. M. (2000). Introdução à mecânica de solos não saturados. Notas de aula.

WEBB, P. A. \& 0RR, C. (1997). Analytical Methods in Fine Particle Technology. Micromeritics Instrument Corporation, 300p.

WILLIAMS, A. A. B. \& DONALDSON, G. W. (1980). Building on expansive soils in South Africa: 1973 - 1980. Proceedings $4^{\text {th }}$ International Conference on Expansive Soils, Vol. II, Denver, Colorado, p. $834-844$.

WILLIAMS, J. \& SHAYKEWICH, C. F. (1969). "Na evaluation of pdy ethylene glycol (PEG) 6000 and PEG 20.000 in the osmotic control of soil water matric potential”. Canadian Journal of Soil Science, 102 (6), p. $394-398$.

WISE, J. R. \& HUDSON, W. R. (1971). An examination of expansive clay problems in Texas. Center of Highway Research, Univ. of Texas, Austin, Res. Rep. 118-5, July.

WOLLE, C. M. \& CARVALHO, C. S. (1988). Medidas "in situ” de tensões de sucção. In: Simpósio sobre Novos Conceitos em Ensaios de Campo e Laboratório em Geotecnia. Anais..., v.2, Rio de Janeiro, 25 - 27 de maio, p. 645 - 665.

YONG, R.N.; MOHAMED, A. M. O. \& WARKENTIN, B.P. (1992). Principles of contaminant transport in soils. Developments in Geotechnical Engineering, 73. Elsevier - Amsterdam London - New York - Tokyo. 
YOSHIMI, Y. \& OSTERBERG, J. O. (1963). Compression of partially saturated cohesive soils. Journal of the Soil Mechanics and Foundations Division. Proceedings of the American Society of Civil Engineers. Vol. 89. SM4, p. $1-24$.

ZUR, B. (1966). Osmotic control the matric soil water potential. Soil Science, V. 102, 6, p.394398. 